\title{
In search of SOCIAL DEMOCRACY
}

Responses to crisis and modernisation

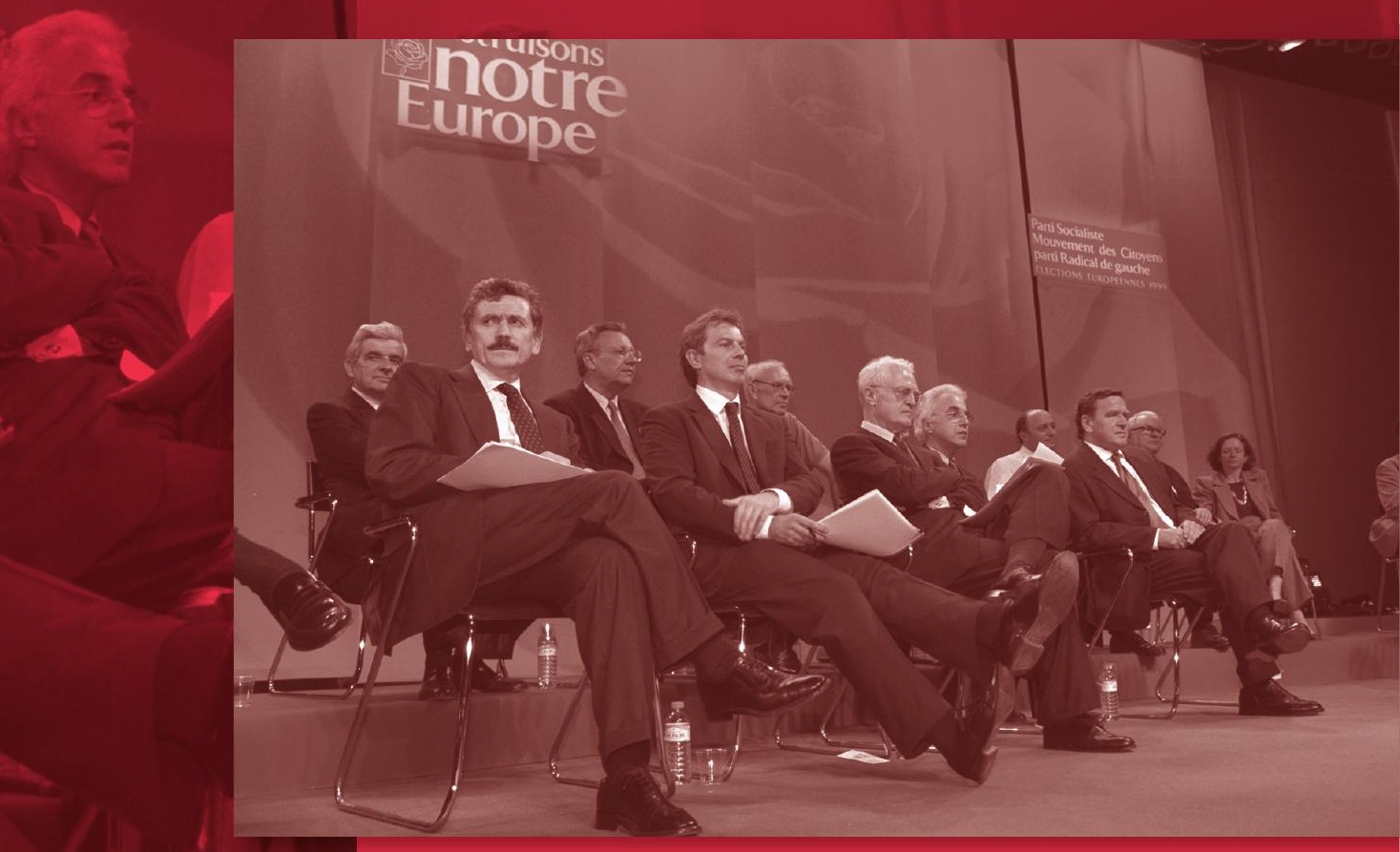

Edited by John Callaghan, Nina Fishman,

B Ben Jackson and Martin Mclvor 



\section{In search of social democracy}

\section{MANCHESTER 1824}

Manchester University Press 



\title{
In search of social democracy
}

Responses to crisis and modernisation

\author{
Edited by \\ JOHN CALLAGHAN, NINA FISHMAN, \\ BEN JACKSON, MARTIN MCIVOR
}

Manchester
University Press 
While copyright in the volume as a whole is vested in Manchester University Press, copyright in individual chapters belongs to their respective authors, and no chapter may be reproduced wholly or in part without the express permission in writing of both author and publisher.

Published by Manchester University Press

Altrincham Street, Manchester M1 7JA

www.manchesteruniversitypress.co.uk

British Library Cataloguing-in-Publication Data

A catalogue record for this book is available from the British Library

ISBN 9780719079207 hardback

ISBN 9781526125095 open access

First published 2009

This electronic version has been made freely available under a Creative Commons

(CC-BY-NC-ND) licence. A copy of the licence can be viewed at https://creativecommons.org/ licenses/by-nc-nd/3.0/

The publisher has no responsibility for the persistence or accuracy of URLs for any external or third-party internet websites referred to in this book, and does not guarantee that any content on such websites is, or will remain, accurate or appropriate.

Typeset

by Servis Filmsetting Ltd, Stockport, Cheshire 


\section{Contents}

List of figures and tables vii

List of contributors ix

Introduction John Callaghan, Nina Fishman, Ben Jackson and

Martin McIvor

\section{Part I After the golden age: social democracy in crisis}

1 Explanations for the neo-liberal direction of social democracy: Germany, Sweden and Australia compared Ashley Lavelle

2 Fiscal policies, social spending and economic performance in France, Germany and the UK since 1970 Norman Flynn

3 From The Future of Socialism (1956) to a future without socialism? The crisis of British social democratic political economy Noel Thompson

\section{Part II Responses to the crisis: the Third Way and other revisions}

4 The political economy of French social democratic economic policy autonomy, 1997-2002: credibility, dirigisme and globalisation Ben Clift

5 The Spanish Socialist Workers' Party: continuity, innovation and renewal Paul Kennedy

6 A new Swedish model? Swedish social democracy at the crossroads Dimitris Tsarouhas

7 The modernisation of German social democracy: towards a third way and back? Hartwig Pautz 
8 The meaning of modernisation: New Labour and public sector reform Eric Shaw

9 Reformism in a 'conservative' system: the European Union and social democratic identity Gerassimos Moschonas

\section{Part III Resources for rethinking}

10 Unlocking the talent of every citizen: debates about potential and ambition in British socialist thought Jeremy Nuttall

11 The continuing relevance of Croslandite social democracy Kevin Hickson

12 The rhetoric of redistribution Ben Jackson

13 Republicanism, socialism and the renewal of the left Martin McIvor

14 Economic democracy instead of more capitalism: core historical concepts reconsidered Adrian Zimmermann 


\section{List of figures and tables}

\section{Figures}

2.1 Evolution of the public sector deficit and the French public sector debt, 1978-2002, as a percentage of GDP

\section{Tables}

1.1 Economic growth rates for six major nations (percentage increase per year)

1.2 Annual average compound growth rate of per capita GDP 12

1.3 Declining economic conditions (annual percentage change) 12

2.1 Public social expenditure 1981-2001, as a percentage of GDP

2.2 Unemployment benefits (insurance system), $2002 \quad 36$

2.3 Unemployment insurance rates, $2002 \quad 36$

2.4 Incomes of employed and unemployed people, $1999 \quad 37$

2.5 Tax rate on low-wage earners: unemployment trap in 200238

2.6 The tax wedge, 2003: Marginal tax rates at income levels proportionate to the average productive wage 38

2.7 Unemployment as a percentage of the labour force, 2002-04 38

2.8 Pension ratios, $2000 \quad 39$

2.9 Participation rates, $2002 \quad 39$

2.10 Total tax revenue as a percentage of GDP, 1975-2003 41

2.11 Taxes on income and profits as a percentage of GDP, 19752003

2.12 Public finances in Germany, 1970-2003

2.13 United Kingdom, public sector receipts and expenditure, 1970-2002 
2.14 Exports, imports and trade balance and rankings, world top six trading countries, 2003

2.15 GDP and GDP per head, 2003

2.16 Average annual volume change in GDP as a percentage, 1993-2003

2.17 Investment flows, 1993 and 2003

2.18 Hours worked per person in employment, 2002

2.19 Productivity, 2002

2.20 Labour costs, euros per hour, 2004

5.1 Spanish general election results, 2004 and 2008 


\section{List of contributors}

John Callaghan is Professor of Politics and Contemporary History at the University of Salford. He is the author of The Labour Party and Foreign Policy (2007), The Retreat of Social Democracy (2000) and Socialism in Britain (1990).

Ben Clift is Senior Lecturer in Political Economy in the Department of Politics and International Studies at the University of Warwick. He is the author of French Socialism in a Global Era (2003), and co-editor of Where Are National Capitalisms Now? (2004). He has written several journal articles and book chapters on French socialism, the French model of capitalism, New Labour and the political economy of social democracy.

Nina Fishman is Honorary Research Professor in the History Department at Swansea University. She is completing a biography of Arthur Horner and collaborating with Richard Whiting on a book about twentieth-century British trade unions. She is also researching in nineteenth- and twentiethcentury comparative European industrial and labour history.

Norman Flynn runs the MSc in Public Policy and Management at SOAS, University of London. He is the author of Public Sector Management (5th edition, 2007), Miracle to Meltdown in Asia: Business, Government and Society (1999), and co-author and editor of Public Sector Management in Europe (1996). He is currently writing International Perspectives on Public Sector Management.

Kevin Hickson is Lecturer in British Politics at the University of Liverpool. His research and teaching interests are in British political ideologies and he has published books and articles on the political thought of all three parties.

Ben Jackson is University Lecturer and Tutorial Fellow in Modern History at University College, Oxford. He is the author of Equality and the British 
Left (2007) and is currently working on the intellectual history of neoliberalism.

Paul Kennedy is Lecturer in Spanish and European Studies in the Department of European Studies and Modern Languages at the University of Bath. He is currently completing a book entitled The Spanish Socialist Party and the Modernisation of Spain for Manchester University Press.

Ashley Lavelle is Lecturer in the Department of Politics and Public Policy at Griffith University in Brisbane, Australia. His research interests include comparative politics, Marxism, social democracy and social movements. He is currently researching a book on why radicals become conservatives.

Martin McIvor is editor of Renewal: A Journal of Social Democracy, and works on research and policy development for the public services trade union UNISON. He has a Ph.D. in political theory from the London School of Economics, where he taught history of political thought.

Gerassimos Moschonas is Associate Professor in Comparative Politics in the Department of Political Science and History at Panteion University, Athens. He also teaches at the Institute of European Studies at the Free University of Brussels (the ULB). He is the author of In the Name of Social Democracy: The Great Transformation, 1945 to the Present (2002) and La social-démocratie de 1945 à nos jours (1994). He is currently working on the relationship between the European Union and social democratic parties.

Jeremy Nuttall is Senior Lecturer in Modern British History at Kingston University. He is the author of Psychological Socialism: The Labour Party and Qualities of Mind and Character, 1931 to the present (2006), and is currently working on the history of the British centre-left.

Hartwig Pautz lectures in social policy at Glasgow Caledonian University's Division of Public Policy, where he obtained his Ph.D. in 2008. He has published on German national identity and on think-tanks and their influence on social policy in the UK and Germany.

Eric Shaw is Senior Lecturer in the Politics Department at the University of Stirling. Formerly a Labour party researcher, he has written extensively on the party, including four books and numerous articles and book chapters. His most recent work is Losing Labour's Soul? New Labour and the Blair Government 1997-2007 (2007).

Noel Thompson is Head of the School of Humanities, Swansea University. His most recent works include Left in the Wilderness (2002) and a second edition of Political Economy and the Labour Party (2006). 
Dimitris Tsarouhas is Assistant Professor in the Department of International Relations at Bilkent University, Turkey. He is the author of Social Democracy in Sweden (2008), and his research interests include social democratic politics, Europeanisation and European political economy.

Adrian Zimmermann is head of the archival department of the Swiss Federal Railways' Heritage Foundation (SBB Historic). He is currently working on a Ph.D. thesis about the origins of liberal corporatism in the Netherlands and Switzerland at the University of Lausanne. 



\section{Introduction}

John Callaghan, Nina Fishman, Ben Jackson and Martin McIvor

The search for social democracy has not been an easy one over the last three decades. The post-war 'golden age', characterised by strong economic growth, full employment and narrowing income inequality, came to an unceremonious end with the global economic slowdown of the 1970s. Sluggish growth, rising unemployment and rampant inflation were all hammer blows to the credibility of the broadly social democratic outlook that had hitherto dominated post-war policy-making in the West. The economic sclerosis of the 1970s consequently offered the opening that the sponsors of so-called 'neo-liberalism' had been seeking to remake the political economy of the industrialised nations. The neo-liberals were remarkably successful at attributing the blame for the economic downturn to ham-fisted Keynesian interventionism, wasteful public spending and inflationary trade unions, and at offering fresh prescriptions for public policy organised around counter-inflationary austerity, welfare state retrenchment, privatisation and deregulation. The new world that social democrats confronted from the 1980s onwards - a world of tax-resistant electorates, the globalisation of capital, and Western deindustrialisation - was one that exercised substantial constraints on traditional social democratic politics. The net result was that the ideas, institutions and social movements associated with social democracy were placed on the defensive and in some countries forced into an undignified retreat.

Yet programmatic revisions in response to new circumstances have long been social democracy's stock in trade (see Sassoon 1996). It was not surprising, then, that a fresh bout of ideological revisionism consumed the democratic left in the 1980s and 1990s, as social democrats sought to come to terms with the latest permutation of capitalism's relentless capacity for innovation. In tandem with these ideological debates, social democratic parties fought, with varying degrees of intensity, to remain electorally competitive, a struggle that reached its fleeting high watermark 
in 2000 when thirteen out of the fifteen EU member states had at least some social democratic participation in government (including Britain, France, Germany and Italy). As with every other episode of social democratic revisionism, however, this period also saw an intensely controversial debate about how far fundamental social democratic commitments were being cast aside by party leaders in the interests of obtaining power. The inevitable, but thorny, questions were posed: did this revisionism simply amount to a neo-liberalisation of the left or did it adumbrate a recognisably social democratic agenda? Were these programmatic adaptations the only feasible ones dictated by the electoral and economic constraints or were there other possible options, other forms of modernisation, that might have yielded greater strategic dividends for the left? Why did some social democratic parties feel it necessary to take their revisionism much further than others?

In Search of Social Democracy brings together prominent scholars of social democracy to address these questions. We aim to take stock of the crisis of classical social democracy in the 1970s and the consequent efforts to modernise social democracy so that it remained a going electoral concern. To do so, we have collected together papers presented at a series of conferences organised around the theme of 'Rethinking social democracy', held in London, Swansea and Sheffield between 2004 and 2006. This collection forms a companion to a previously published volume, also drawn from these conferences, which focused on social democracy in its golden age (Callaghan and Favretto 2007). This book picks up the story of social democracy as it sailed into choppier waters.

Although there is no shortage of books and articles on social democracy's fortunes in the late twentieth century, this volume stakes a claim for distinctiveness because it is the first to be able to reflect in detail on the left's experiences in government in the 1990s and early twenty-first century. Previous discussions of the modernisation of social democracy were published on the cusp of these governments or at an early stage of their terms in office, when the trajectories of the left's governing projects were as yet indistinct (see e.g. Kitschelt 1994; Sassoon 1997; Callaghan 2000; Glyn 2001; White 2001). We are now able to build on these contributions by assessing in greater depth how the new social democratic revisionism fared in government. In order to make this task manageable, we have focused our attention on the social democratic heartland of Western Europe, although Australia and the United States also make an appearance. We have narrowed our geographical scope with some regrets, but we are convinced that a comparative analysis of those nations in which social democracy has historically exercised greatest influence - the industrialised West - offers us the most coherent and fruitful approach to this subject. 
The book is divided into three parts. In Part I, 'After the golden age: social democracy in crisis', a reckoning is made with the underlying causes of the end of social democracy's golden age and thus with the magnitude of the challenges faced by social democratic parties after the 1970s. Ashley Lavelle argues in the opening chapter that the cross-national trend in social democratic parties since the 1970s has been towards an accommodation with neo-liberalism and a corresponding dilution of traditional social democratic commitments. Drawing on the case studies of Australia, Germany and Sweden, Lavelle attributes this 'neo-liberalisation' of social democracy to the end of the post-war economic boom. Lower levels of economic growth mean that it is no longer possible, Lavelle argues, to pursue golden-age-style redistributive policies without arousing the decisive opposition of capital. In the following chapter, Norman Flynn offers support for elements of Lavelle's analysis, but also departs from it. Flynn compares the economic performance, fiscal policies and social spending regimes in France, Germany and the United Kingdom since 1970 in an attempt to determine how far the so-called 'European social model' has survived in the face of economic and demographic pressures and whether less generous social spending can be correlated with stronger economic growth. Although Flynn finds all three economies to have been placed under significant fiscal strain, he also finds that there have been diverse national responses to these pressures and argues that broadly social democratic institutions have been surprisingly durable, particularly in France and Germany. In the final chapter of Part I, Noel Thompson examines the ideological crisis that engulfed social democracy during the 1980s. Thompson focuses on the debate about economic strategy on the British left and traces how social democratic politicians and economists responded to the dethroning of Keynesianism by neo-liberalism as the dominant model of economic policy-making. Thompson argues that this period sees the defeat of a distinctively social democratic economic strategy in Britain, since it was ultimately rendered irrelevant by changing economic circumstances, new electoral preferences and the ideological dominance of the New Right. This provides a suitably gloomy note on which to make the transition to Part II, 'Responses to the crisis: the Third Way and other revisions'.

Having set the stage in Part I with an analysis of the constraints operating on social democratic parties from the 1970s onwards, Part II moves on to examine detailed case studies of how particular social democratic parties responded in government to this changed political terrain. Five crucial national cases are investigated here. Ben Clift opens Part II with an analysis of the economic strategy of the French Socialist Party between 1997 and 2002. He argues that Lionel Jospin's government created 
significant space for social democratic policy activism by committing itself to macroeconomic stability and hence ensuring that it enjoyed credibility with financial markets. A similar picture to that painted by Clift emerges from two of the other case studies explored in Part II. Paul Kennedy and Dmitris Tsarouhas show that in Spain and Sweden respectively difficult political and economic constraints have necessitated programmatic and strategic adaptation on the part of the Spanish Socialist Workers' Party (PSOE) and the Swedish Social Democrats (SAP) but that, like the French socialists, the PSOE and SAP have nonetheless succeeded in pursuing a recognisably social democratic course. The PSOE and the SAP, we might also note, have probably been the two most electorally successful left parties of the last thirty years. The verdicts on the German Social Democratic Party (SPD) and the British Labour Party, given by Hartwig Pautz and Eric Shaw respectively, are more negative. Pautz examines the SPD's programmatic debates from the 1990s until the present day, including its engagement with 'third way' revisionism, and finds that the outcome has been deep confusion in the SPD's identity, policies and electoral appeals. Shaw directs our attention to the 'third way' government par excellence, the Blair-Brown administration in Britain, and in particular to Labour's approach to public services. Shaw acknowledges the significant public investment in education and healthcare undertaken by Labour since 1997, but also sketches in the government's controversial use of market mechanisms in public service delivery and their consequences for core social democratic objectives such as equality and social solidarity. Part II concludes with a chapter that traces the evolution of international approaches to social democracy. Gerassimos Moschonas looks at the impact of European integration on social democracy in this period and argues that the particular institutional structure of the EU poses a further significant constraint on the capacity of social democratic parties to undertake meaningful political change. According to Moschonas, although attachment to the cause of European integration in the 1980s and 1990s enabled social democratic parties to win new support from the educated middle class, it also consolidated and deepened the decomposition of the traditional political identity of the moderate left.

Part III of the book, 'Resources for rethinking', aims to contribute to a broader conversation about the future of social democracy by considering ways in which the political thought of 'third way' social democracy might be radicalised for the twenty-first century. The emphasis here is on the continuing salience of left-wing ideological traditions that have been unjustly neglected in the rush to modernise social democracy in the 1980s and 1990s. Jeremy Nuttall focuses on the evolution of the British left's ideas about unlocking the potential of each individual and argues that this represents a compelling electoral battleground 
on which the contemporary left could engage with the arguments of the neo-liberal right. Kevin Hickson makes the case for the continuing relevance of Anthony Crosland's vision of social democracy and responds to a variety of critics who have argued that Crosland's ideas have been rendered inapplicable by post-1970 economic and political developments. Ben Jackson contests the portrayal of traditional social democratic rhetoric in the political thought of modernisers by undertaking a comparative analysis of the rhetoric used in Britain and the United States to argue for economic redistribution during the struggle for the welfare state. His findings dispel some serious misconceptions about how present-day social democratic politicians in Britain and the United States might resuscitate a public language of social justice. Martin McIvor weighs up how far the recent retrieval of republican ideas by political theorists offers social democrats a promising source of fresh intellectual inspiration. He concludes that, although there is indeed much to be said for incorporating republican insights into social democracy, it is also important to correct for the individualist emphasis of republican political economy by retaining the traditional socialist goal of democratic collective control of the economy. In the following chapter, Adrian Zimmermann examines precisely this historic socialist commitment to economic democracy and sketches the development of ideas about industrial self-government across Western Europe in the twentieth century. He argues that economic democracy should be seen as a fundamental component of social democratic ideology, ripe for reappropriation in the twenty-first century. Nina Fishman concludes the book by reflecting on the early history of the social democratic tradition after the formation of the Second International in 1889. She also indicates the continuing relevance of this tradition by looking forward, to the prospects for social democracy in the twenty-first century. At a time of economic turbulence and environmental degradation, she argues, the characteristic social democratic emphasis on collective, democratic, non-market solutions still holds a considerable appeal.

As should be apparent, no party line has been imposed on the contributors. A variety of perspectives emerge in the following pages - some sceptical of social democracy's prospects, others more sanguine; some supportive of the performance of social democratic parties in government, others bitingly critical - but all of the contributors are united by the conviction that this represents a line of enquiry that is essential to understanding the current politics of the industrialised world and, in particular, to determining the feasibility of more egalitarian and democratic social outcomes than have been possible so far in the era of neo-liberalism. 


\section{References}

Callaghan, J. (2000) The Retreat of Social Democracy (Manchester: Manchester University Press).

Callaghan, J. and Favretto, I. (eds) (2007) Transitions in Social Democracy: Cultural and Ideological Problems of the Golden Age (Manchester: Manchester University Press).

Glyn, A. (ed.) (2001) Social Democracy in Neo-Liberal Times: the Left and Economic Policy Since 1980 (Oxford: Oxford University Press).

Kitschelt, H. (1994) The Transformation of European Social Democracy (Cambridge: Cambridge University Press).

Sassoon, D. (1996) One Hundred Years of Socialism (London, I. B. Taurus).

Sassoon, D. (ed.) (1997) Looking Left: European Socialism after the Cold War (London: I. B. Taurus).

White, S. (ed.) (2001) New Labour: the Progressive Future? (Basingstoke: Palgrave) 


\section{Part I}

\section{After the golden age: social democracy in crisis}





\title{
Explanations for the neo-liberal direction of social democracy: Germany, Sweden and Australia compared
}

\author{
Ashley Lavelle
}

Several explanations have been put forward as to why social democrats have adopted neo-liberal policies since at least the 1980s. Ideological trends, the consequences of globalisation and European integration, and electoral factors, all get a strong mention in the literature. This chapter suggests that a more persuasive explanation for social democrats' embrace of neo-liberalism lies with the end of the post-war boom in the early 1970s. Not only did the ensuing lower economic growth rates undercut the material base for the expansionary programmes of the post-war era, they rendered impossible the pursuit simultaneously of policies that reduced inequality and raised living standards and fitted the needs of capital accumulation. In the new economic context, neo-liberal policies were now required to open up business opportunities and remove the constraints on capital to enable it to flow into untapped areas of profit-making. This chapter begins by looking at the impact of the change in economic conditions on social democracy in general, before examining the specific cases of Germany, Sweden and Australia.

\section{Social democracy and neo-liberalism}

Social democrats have embraced neo-liberal policies since at least the 1980s. The various 'modernisations' and revisions of social democrats are discussed in succeeding chapters. Here we briefly spell out this chapter's approach to neo-liberalism in order to give a clear sense of the argument being made. According to Harvey (2005: 2):

Neoliberalism is in the first instance a theory of political economic practices that proposes that human well-being can best be advanced by liberating individual entrepreneurial freedoms and skills within an institutional framework characterized by strong private property rights, free markets, and free trade. The role of the state is to create and preserve an institutional framework appropriate to such practices. 
Neo-liberalism is almost synonymous with the 'Washington Consensus', a term coined by economist John Williamson to refer to ten policies that now enjoy almost universal support in mainstream politics, including fiscal discipline, free trade, foreign direct investment liberalisation, privatisation and deregulation (Williamson 2002). Such policies strive to liberate capitalism and open up new areas for capital accumulation (Harvey 2006: 25, 26). In contrast, traditional social democratic policies aimed to reform and regulate capitalism in order to reduce inequality and prevent market failure. Neo-liberalism is pro-business, though not always 'promarket' (Pollin 2003: 8). As Ashman (2003) puts it, neo-liberalism is not opposed to state involvement in the economy per se, but instead aspires to "freedom" for capital from state "interferences"'. Neo-liberalism in fact deploys a strong state to protect private property and open up new areas for capitalist exploitation (Harvey 2005: 21).

This broader conception is preferable to interpretations of neo-liberalism that see it as designed simply to reduce the size of the state by cutting taxation and government spending. There is not one model of neo-liberalism. Ryner invokes the notion of left and right 'poles' of neo-liberalism, while Watkins refers to the 'high road', class warfare model pursued by the likes of Thatcher and Reagan, and the more common 'low road' where neoliberal policies are imposed by 'stealth' (Ryner 2004: 98, 102; Watkins 2004: 26). It is therefore possible for two different governments to be neoliberal. Just as there is not one version of neo-liberalism, social democrats have not embraced it in an identical fashion. Driver and Martell argue that New Labour's neo-liberal policy moves were faster and more ideologically driven than in France, Sweden and Germany, which can be explained partly by British 'traditions of individualism and limited government' (Driver and Martell 1998: 172, 173).

Notwithstanding such national variations, the broader trend is clear. Former German Social Democratic Party (Sozialdemokratische Partei Deutschlands - SPD) Finance Minister Oskar Lafontaine (2000: 25) laments the fact that in Europe "we are now all neo-liberals and supply-side politicians'. The American version of free-market capitalism has been in the ascendancy (Stiglitz 2003: 4). In order to appreciate how neo-liberalism achieved the status of an orthodoxy, we need to examine the impact of the collapse of the post-war boom.

\section{The end of the post-war boom}

A range of explanations exists for the neo-liberal policy direction of social democracy. These include: ideological trends, which have been running in favour of free-market policies; economic globalisation and Europeanisation, 
Table 1.1 Economic growth rates for six major nations (percentage increase per year)

\begin{tabular}{lcc}
\hline Country & $1950-73$ & $1973-97$ \\
\hline USA & 3.8 & 2.5 \\
UK & 3.0 & 1.8 \\
Germany & 6.0 & 2.1 \\
France & 5.0 & 2.1 \\
Italy & 5.6 & 2.4 \\
Japan & 9.2 & 3.3 \\
\hline
\end{tabular}

Source: Kotz 2001: 94

which are widely interpreted as reducing the policy options available to government to a relatively uniform set of pro-business policies; and electoral factors that offer inducements for social democrats to target more affluent sectors of the electorate. Rather than discussing these in detail, ${ }^{1}$ in what follows I will put the case for an alternative explanation based on the impact of the end of the post-war boom.

The boom that ensued after the Second World War represents, according to one historian, 'the most dramatic, rapid and profound revolution in human affairs of which history has record' (Hobsbawm 1994: 286). Rates of growth and accumulation did vary from country to country, but the advanced capitalist world was generally characterised by 'historically unprecedented rates of investment, output, productivity, and wage growth, along with very low unemployment and only brief and mild recessions' (Brenner 2002: 7). In his millennial study of the world economy, Maddison argues that the 'golden age' of 1950-73 has been 'by far the best [phase] in terms of growth performance' (Maddison 2001: 125).

The boom ended abruptly in 1974 (see Tables 1.1-1.3). ${ }^{2}$ The International Monetary Fund's (IMF) managing director told his annual conference in 1975 that the 'declines in output that have occurred in the industrial countries during 1974 and $1975 \ldots$ are unprecedented in the post-war period as to both magnitude and duration' (cited in Hayden 1977: 7). From 1974 onwards, 'output, productivity, and export growth all fell sharply, instability in export volumes and GDP increased, and unemployment and inflation both rose' (Glyn et al. 1990: 45). Economic growth rates have been steadily declining ever since (Harvey 2006: 42). Brenner writes that in the first half of the 1990s the three largest economic blocs (Japan, North America and Western Europe) experienced their worst five-year period of growth performance since 1945 (Brenner 2002: 46). According to Stiglitz (2003: 21), the 1990s were 'a decade in which one economic crisis seemed to follow another - every year there was another crisis'. 
Table 1.2 Annual average compound growth rate of per capita GDP

\begin{tabular}{lccc}
\hline Region & $1870-1913$ & $1950-73$ & $1973-98$ \\
\hline Western Europe & 1.32 & 4.08 & 1.78 \\
Japan & 1.48 & 8.05 & 2.34 \\
Total advanced capitalist & 1.56 & 3.72 & 1.98 \\
World & 1.30 & 2.93 & 1.33 \\
\hline
\end{tabular}

Source: Maddison 2001: 129

Table 1.3 Declining economic conditions (annual percentage change)

\begin{tabular}{lcccc}
\hline GDP & $1960-69$ & $1969-79$ & $1979-90$ & $1990-2000$ \\
\hline US & 4.6 & 3.3 & 2.9 & 3.2 \\
Japan & 10.2 & 5.2 & 4.6 & 1.3 \\
Germany & 4.4 & 3.6 & 2.15 & 1.9 \\
Euro-12 & 5.3 & 3.7 & 2.4 & 2.0 \\
G-7 & 5.1 & 3.6 & 3.0 & 3.1 \\
\hline
\end{tabular}

Source: Brenner 2002: 47

Then British Chancellor Gordon Brown observed that the first three years of the twenty-first century had 'seen the first simultaneous world slowdown for 30 years ... and a downturn stretching across every continent for the first time since the 1970s'. He pointed out that even during 'the world recessions of the early 1980s and 1990s world trade continued to grow by around 5 per cent a year ... for much of 2001 and 2002 world trade barely grew at all' (Brown 2003).

Growth has been much stronger over 2004-6, driven in part by the rising share of world GDP accounted for by high-performing China and India (Treasury Department 2006). But the 'sub-prime' mortgage credit crisis hovers ominously over the world economy in 2007-8 (Nason 2007) and, given the economic trends since the 1970s, it would be heroically optimistic to see the growth rates of the last few years as the harbinger of another upturn. Indeed, former US Treasury Secretary Larry Summers has predicted that the American economy is headed for recession in 2008, with likely serious consequences for global growth (cited in Wood 2007: 16).

\section{The impact on social democracy}

Social democracy's problems did not commence with the conclusion of the post-war boom. As Callaghan (2002: 436) comments, the post-war period appears as a 'golden age' by contrast only with the 'grim' pre-war record 
of social democracy. Social democrats have generally failed to live up to the expectations of their supporters. An important reason for this is that their aspirations for social reform are restricted to what capitalist economic structures will permit (see Callinicos 1997; Birchall 1986). It is thus by no means a recent development for social democratic governments to implement policies that both favour business and disappoint labour. Yet social democrats did manage to achieve some significant social reforms in the post-war period, only for these to give way eventually to neo-liberal policies, as we shall see from the case studies that follow. The main factor in this was the change in economic conditions, which historically have been critical to social democrats' ability to oversee reforms that would allow their working class constituents to live a little easier. As Head and Patience (1979: 5) explain, a 'reform government's programme is likely to be very expensive', and therefore it is 'unusually dependent on buoyant economic conditions to help ensure a rapid expansion of government revenues to avoid a crippling budget deficit'.

The post-war boom was important not just because consistent high rates of growth supplied a material base for redistributive programmes: they also allowed such policies to be pursued without raising the ire of capital. As Moschonas (2002: 65, 66) argues, "the satisfaction of working-class interests' under capitalism hinge 'largely on their compatibility with the private profits of the owners of capital. When such compatibility does not exist . . . capital gets out'. Social democrats' ability to offer reforms to its working-class constituents and satisfy business interests was strengthened considerably during the boom because the buoyant conditions meant that such reforms were comparatively much cheaper, and did not threaten the economic system (Eley 2002: 7; see also Harvey 2006: 14). Thus, to some extent, the boom nullified the social democratic catch-22 identified by Coates (cited in Birchall 1986: 22, 23), whereby strong economic growth is necessary to finance social reforms beneficial to workers and the poor, but the generation of such growth hinges on developing policies favourable to capital. The post-war boom seemed to suggest that policies for labour and capital were not mutually exclusive.

This explains why the post-war period is widely regarded as a 'golden age' for social democracy. It is arguable in all three case studies examined below that the most significant social democratic measures were implemented on the strength of the post-war economy. When the boom ended, so largely did the reforms. The reasons for this are straightforward. In times of economic downturn, there is sufficient wealth to fund social reforms, but now such reforms are more damaging to the profits of firms because they need to be funded by higher taxes on profits and the wealthy, rather than by the stronger revenues and incomes generated by a booming economy. 
Redistributive reforms are therefore much more strongly resisted in these tighter commercial conditions, which is why the apparent class harmony of the post-war period gave way to "polarisation and periodic eruptions of conflict' (Padgett and Paterson 1991: 49). Dumenil and Levy (2004, 9) argue that neo-liberalism was driven by a decline in profit rates in the advanced countries which, it was believed, could be restored only by policies that improved the conditions for business investment and expanded investment opportunities, such as the Washington Consensus-style policies cited above. If these were consistent with the needs of accumulation because of their liberating effects on capital, social democratic policies on the other hand 'had by the mid-1970s proven inconsistent with the requirements of capital accumulation' (Harvey 2006: 15).

Also conflicting with the needs of capital accumulation was Keynesianism, which was discredited by the economic crisis (see Hall 1993: $284,285)$, and eventually replaced by neo-liberalism. This had major implications for social democrats: Keynesianism's status as orthodoxy allowed them to avoid having to choose between mainstream economics and government intervention to raise living standards, expand welfare, and reduce inequality (Padgett and Paterson 1991: 22, 23). To persist with Keynesian solutions would have provoked conflict with capital, something social democrats have rarely countenanced.

To see how the change in economic conditions in the 1970s affected social democracy, we shall examine the cases of Germany, Sweden and Australia. These are important case studies. In the latter case, the Australian Labor Party (ALP) served as a model for some 'modernising' social democrats, such as New Labour in Britain, partly because it commenced its neo-liberal programme relatively early (in the early 1980s) and enjoyed a long stretch of power (1983-96). On the other hand, the SPD's age, position, size and international connections make it the most influential social democratic party in Europe, and therefore in attempting 'to assess the future of social democracy no party is more important than the SPD' (Paterson 1986: 127). Sweden has long been considered a social democratic paradise, but as we shall see the collapse of the post-war boom has also been injurious to Swedish social democracy.

To what extent are the cases comparable? A distinction often made is between the 'labourist' parties of the UK and Australia and the 'social democratic' parties of Europe. But the differences between labour parties and social democratic parties are frequently overstated (see Berger 1994). Fielding argues that despite national variations, 'all social democrats sought to transform free market capitalism into a more regulated system they described as socialism' (Fielding 2003: 60). Finally, the compression of these parties into one ('social democratic') category is made possible also 
by the existence of the Socialist International, a grouping that contains 'socialist', 'social democratic' and 'labour' parties (Birchall 1986: 15).

\section{Germany}

The SPD has steadily embraced policies that can be described as neo-liberal (see Lavelle 2008a). There is considerable evidence to suggest that its abandonment of reformist politics in government in the 1970s was a response to the breakdown of the boom. In West Germany, annual GDP averaged 7.5 per cent between 1950-59 (Minnerup 1976: 13). Over the longer period of 1950-73, annual growth averaged six per cent (Kotz 2001: 94). This heady growth phase contributed to significant reforms by the SPD when it governed in coalition with the Free Democratic Party (Freie Demokratische Partei-FDP) ${ }^{3}$ between 1969 and 1982. Potthoff and Miller list the reforms of which it could boast at the 1976 election:

relatively high economic stability; a tight social safety-net with significant improvements, such as flexible retirement age, guaranteed works' pensions, pension schemes for the self-employed, health insurance for farmers, a new youth employment protection law, revision of child benefit, adjustments and increases in war victims' pensions, rehabilitation and special employment rights for the severely handicapped; extension of co-determination; new married couples' and families' legislation; [and abortion reform] . . . (2006: 236)

These reforms were premised on economic expansion. The party's Bad Godesberg programme of 1959 described the boom as akin to a 'second industrial revolution', which made possible 'a rise in the general standard of living greater than ever before and the elimination of poverty and misery still suffered by large numbers of people' (cited in Birchall 1986: 82). SPD plans for reform in the 1960s and 1970s assumed continued growth (Potthoff and Miller 2006: 232).

As is the case elsewhere, SPD ambitions for reform were badly dented by the sea change in economic conditions. Economic growth fell from 4.7 per cent in 1973 to 0.2 per cent in 1974 and -1.4 per cent in 1975 (Potthoff and Miller 2006: 231). Growth averaged six per cent between 1950 and 1973, but fell to just 2.1 per cent in the years 1973-97 (Kotz 2001: 94). According to Brenner's data, the profitability of German manufacturing declined 53 per cent between 1955 and 1973, after which 'Germany entered the long downturn, along with the rest of the world economy'. Furthermore, there was a 'very major recession for the German economy at the end of the 1970s. During the three years 1980, 1981, and 1982, the average annual growth of GDP fell to 0 per cent'. There was also a wider decline in business profitability (Brenner 2002: 120-5). 
According to Potthoff and Miller (2006: 250), rising unemployment and lower growth and tax revenues undermined the welfare state. The SPD 'turned increasingly toward economic liberalism, and introduced a series of austerity policies' (Jahn and Henn 2000: 31). The SPD between 1974 and 1982 twice 'made major cut-backs and changes in labour market policy to curb the growth of expenditure' (Webber 1983: 24). The SPD in 1975 launched a 'major wave' of cuts to spending on transport, health and education (Birchall 1986: 205). Wolfe (1978: 100) described the policies as "barely distinguishable from those followed by an earlier generation of unabashed West German admirers of free market capitalism', while Minnerup (1976: 10) regarded SPD Chancellor Helmut Schmidt's policies as tantamount to the 'open abandonment of reformism'. A mainstream news magazine argued that traditional SPD voters would bear the brunt of cutbacks aimed at balancing the budget and reducing borrowing. Trade unions campaigned against the government on the slogan 'enough is enough' (Potthoff and Miller 2006: 244, 245).

\section{The Schröder years}

Germany thus experienced a slowdown comparable to most industrialised countries. But it has suffered comparatively weaker conditions since reunification when it 'entered its worst and longest recession since 1950. Between 1991 and 1995, GDP grew at an average annual rate of just 0.9 per cent' (Brenner 2002: $120 \mathrm{ff}$.). Compared to an average of 7.7 per cent in the period 1950-61 and 4.4 per cent between 1961 and 1973, average annual growth during the years 1992-2002 was a mere 1.4 per cent (Silvia 2003: 1, 3; Funk 2000: 20). Germany was hit hard by the world recession in the early 2000s (Potthoff and Miller 2006, 391). In 2003, it was observed that for 'the first time since the Second World War, the economy has been essentially stagnant for three straight years' (Silvia 2003: 1,3).

When the SPD came to power in 1998 after sixteen years in opposition, Chancellor Gerhard Schröder stressed the gravity of the budgetary situation: 'Structural adjustments will be unavoidable. All items of federal expenditure will have to be examined. Government action must be more accurately geared to our objectives and be made more economically efficient' (Schröder 1998). Potthoff and Miller argue that in light of 'the huge mountain of debt which had accumulated under the Kohl government, there was precious little scope for closing the gap between rich and poor', while the 'empty coffers' meant that 'the government could scarcely be a distributor of social munificence' (Potthoff and Miller 2006: 365).

As we have seen, neo-liberal policies are designed to create opportunities for investment and improve conditions of capital accumulation in an effort 
to revive economic growth. Consistent with this, the government's Agenda 2010 policies aimed to improve Germany's success 'as a strong business location' (Federal Government 2004: 5). ${ }^{4}$ The policies attracted the praise of chief executives of prominent US corporations, who have previously criticised Germany for its taxes being 'too high, the labor market too inflexible, and non-wage labor costs too burdensome' (Regierung Online 2003). Germany has suffered from low levels of foreign direct investment since the early 1990s, and investment levels in general have fallen from 26.5 per cent of GDP during the 1960s to 19.4 per cent between 2000 and 2003 (Kitschelt 2000: 200; Silvia 2003: 6).

By increasing investment levels, it was hoped, growth would revive. ASPD policy document in 2003 argued that "economic growth over the past three years has remained well below the forecasts, indicating that the reforms did not go far enough and that there is a need for more far-reaching measures ... This is the thrust of Agenda 2010'. It further argued that the 'extent of . . . the dismantling of social services ... will ultimately be determined by the extent of economic growth in Germany and how the fruits of this growth are distributed'. Therefore, one aim of the reforms was to put Germany 'back on the road to growth' (SPD 2003: 4, 7). Finance Minister Hans Eichel (2000) argued that 'a reliable fiscal policy will brighten the growth prospects for the Germany economy'. Schröder (2003) also stated that the policy would 'provide short-term stimulus for growth'.

By generating growth and investment it was hoped that the fiscal pressures would ease. The SPD noted in 2003 that: 'Tax revenue is dwindling. Tax revenue in 2002 dropped by around $1.2 \%$ or 5.3 billion [euros] compared with 2001. This trend continued in the first quarter of 2003'. At the same time, however, it pointed out that social security spending in the federal budget had risen from 4.1 billion euros in 1961 to 106.9 billion in 2002. The SPD also referred to the economic 'burdens' created by reunification in the form of the 80 billion euros diverted annually to the eastern Länder (SPD 2003: 3, 4, 2). In this context, the Agenda health reforms were projected to save 23 billion euros per year by 2006, helping to "ensure that Germany's health care system remains financially viable in the future' (Federal Government 2004: 14). The economic pressures underlying such statements are undeniable.

\section{Sweden}

Like its German counterpart, the Swedish Social Democratic party (Socialdemokratiska Arbetarpartiet - SAP) has increasingly adopted neoliberal policies (see Lavelle 2008a and Chapter 6 in this book). The SAP implemented its major social reforms - the introduction and expansion of 
primary and secondary education, public housing policies, labour laws, hospital care and care for the elderly - during the post-war boom period (Carlsson and Lindgren 1998: 92, 93). ${ }^{5}$ Sweden's abstention from both world wars gave it a head start on many European countries, with growth between 1946-50 averaging 4.5 per cent (Sparks and Cockerill 1991: 95, 96). Economic growth in the 1950s and 1960s averaged 3.3 per cent and 4.6 per cent respectively (Swedish Institute 2004).

Swedish social democracy provides less clear-cut evidence of an immediate impact following the collapse of the post-war boom than both the German and Australian cases. This is related to the SAP's loss of power for six crucial years (1976-82) shortly after the crisis struck. Also, Sweden initially did not suffer the effects of the international recession in 1974-75 (Särlvik 1977: 93). Therefore, the changes were most evident when the SAP returned to power in 1982 (Huber and Stephens 1998). Even so, Kesselman (1982: 416) had already commented that 'the SAP has moved to the right in response to the international economic crisis'. When it did return to power, it confronted a depleted economic base. In the 1970s, Sweden's economy grew at a slower rate than the EU average (Swedish Institute 2006: 1). According to Lundberg, there was a 'near cessation of economic growth during 1974-83', and this had serious repercussions for 'the working of the system', which for over twenty years had assumed 'a steady growth rate (around 4 percent)' (Lundberg 1985: 33, 24). Indeed, growth averaged just two per cent annually in the years 1980-2003 (Swedish Institute 2004).

Sweden was particularly vulnerable given its costly welfare state. Each decline in economic growth by the value of one percentage point reputedly causes an increase of 0.7 per cent in public expenditure (Madeley 1999). A related economic pressure arose from the fact that Swedish unemployment benefits are comparatively high as a proportion of GDP (Einhorn and Logue 2003: 161). Thus, as unemployment rises the fiscal pressures are even greater than in other countries. Official unemployment rose from just 1.7 per cent in 1990 to eight per cent in 1994 (Swedish Institute 2004). Huber and Stephens (1998) note that despite improved export figures in 1994, 'the high unemployment and thus pressure to cut entitlements continued'.

Despite a modest economic recovery in the early 1980s, Swedish economic growth remained below the EU average (Swedish Institute 2006). Sweden was hit even harder by the recession beginning in 1990. Economic growth declined 5 per cent, and employment dropped 10 per cent between 1990 and 1993 (Swedish Institute 2006: 2). According to an IMF report, this was the 'deepest and longest recession since the 1930s', and it challenged the very viability of the welfare state. The report noted that 
reforming the social security system was not acknowledged as a necessity 'until the adverse budgetary effects of the most recent economic downturn became apparent' (Lachman et al. 1995: 1-3, 31). According to Norberg (2006: 87, 88), the early 1990s recession, while not making major inroads into Sweden's high level of taxes or welfare state, nonetheless had significant policy consequences:

Marginal tax rates were cut [in response], the central bank was made independent, public pensions were cut and partially privatized, school vouchers were introduced, and private providers were welcomed in health care. Several markets were deregulated, like energy, the post office, transportation, television and, most importantly, telecom, which opened the way for the success of companies like Ericsson.

Furthermore, while the early 1990s recession was international in scope, Sweden was particularly affected (Swedish Institute 2004). The recession, according to Notermans (2000: 31), caused large budget deficits, and 'forced the SAP to pursue welfare retrenchment'. The austerity programme enacted by the SAP under Göran Persson from 1995, which amounted to cuts worth eight per cent of GDP, was a response to a fiscal crisis rather than indicative of an ideological shift (Vartiainen 1998: 22). While the Swedish economy has experienced a recovery since 2002, as The Economist (2006) notes this 'should be seen mainly as a rebound from the 1990s trough'.

SAP politicians and thinkers concede the relationship between declining economic growth and cuts to welfare. Former SAP Prime Minister Ingvar Carlsson asserts simply that social reforms require the "money to finance them with! If the economy turns down it is not possible to maintain the level of welfare benefits' (Carlsson and Lindgren 1998: 77). Persson (2004) commented that 'we are so heavily dependent on economic growth to maintain our European social model'. He conceded the unpopularity of some of the SAP's reforms, but nonetheless insisted upon their necessity in order to generate economic growth, without which 'it is not possible to maintain a generous welfare-model' (Persson 2004). Then SAP Finance Minister Pär Nuder in 2004 referred to the 'time when growth was negative in the early nineties' and the 'devastating consequences for security and justice that zero growth society caused' (Nuder 2004).

Related to the change in policies brought on by the end to high growth was the increasingly fractious nature of capital-labour relations. The tension and conflicts somewhat submerged by the boom were once again visible, evident in 'the nation-wide strikes and lock-outs of May 1980' (Webber 1983: 30). Swedish employers launched an 'offensive' against social democratic policies, and the main employer's organisation 'withdrew from the system of corporatist representation of government bodies' 
(Pontusson 1994: 39). Even conflict between the political blocs in the Swedish party system became much more pronounced than during the 'golden decades' when social democratic reforms enjoyed broad support (Lundberg 1985: 24). The employer 'offensive' was a reaction to a worsened economic climate that demanded policies to open up opportunities for business investment and improve capital accumulation rates, and which necessarily caused conflict with labour.

\section{Australia}

In achieving its most impressive reforms during the post-war years, the ALP conforms to the international social democratic pattern. The reformist record of the Labor government of Ben Chifley (1945-49) included 'the most considerable programme of legislative and executive measures for nationalisation and public enterprise in the Commonwealth's history'. The government also engaged in greater 'general intervention and planning in economic and social affairs', with its policies geared towards full employment, better workplace conditions, and an improvement in the "equalisation of wealth, income and opportunity' (Crisp 1978: 289, 290).

Australia experienced consistently high economic growth during the long boom (Bolton 1970: 283). Economic growth per annum averaged 3.8 per cent, 4.2 per cent and 5.3 per cent in the 1940s, 1950s and 1960s respectively, which, particularly in the latter two decades, are well above the twentieth-century average of 3.4 per cent (see Lavelle 2008b). Labor languished in opposition for most of this period (1949-72). Yet, when it returned to power in 1972 under the leadership of Gough Whitlam, it implemented during its three years in power ${ }^{6}$ significant reforms based on the strength of the economy, including heavy spending on areas such as health, education, the arts, urban and regional development, and resources for disadvantaged groups. Even Marxist critics noted that in 1973 the government ramped up public spending, 'first raising pensions in line with plans to peg them at 25 per cent of average weekly earnings. The 1973 budget doubled spending on education, tripled outlays on urban development, quadrupled spending on housing' (O'Lincoln 1993: 132). Whitlam (1978: 10) himself conceded that 'we made minimal attacks on entrenched privilege'. But, compared to the disappointing results of Labor in power in the 1980s and 90s when the Bob Hawke and Paul Keating governments instituted many neo-liberal reforms, the Whitlam government is often presented as a social democratic success and model (e.g. Hocking and Lewis 2003).

What is often neglected in reflections on the experience of the Whitlam government, however, is the jettisoning of its reform plans once the boom ended in 1974. As elsewhere, Australia in 1974-75 suffered declining 
growth, high inflation and rising unemployment (Dyster and Meredith 1990: 221; Brezniak and Collins 1977). Compared to the 4.2 per cent and 5.3 per cent growth achieved on average per year in the 1950s and $1960 \mathrm{~s}$ respectively, this fell to 3.5 per cent in the 1970 s and 3.3 per cent in the 1980 s, before rising slightly to 3.5 per cent in the 1990s. It then fell to less than 3 per cent in the first six years of the twenty-first century, despite the economy being in the midst of a boom (see Lavelle 2008b).

The first major signs of a change in policy direction were evident in 1974-75 towards the end of the government's reign when it reacted to the economic crisis with a number of measures, including establishing an Expenditure Review Committee prejudiced against any further public spending increases (Wood 1975: 9). Such decisions constituted, according to journalist Paul Kelly (1976: 59), 'the most dramatic reversal in economic policy in the shortest possible time'. Another press commentator remarked: 'The Government of reform has been transformed into a Government of laissez faire' (McDougall 1975: 1). The national ALP conference $^{7}$ in early 1975 also reflected, according to Ormonde (1981: 200), 'an historic change in Labor philosophy'. In his address to conference, Whitlam spoke of the 'special difficulties [the recession created] for a democratic socialist party ... [W] find ourselves now in a position of seeking ways of restoring profitability' (cited in Rydge's 1975: 35). A conference motion to strengthen the public sector was defeated in favour of a resolution emphasising the need to restore private sector profits (Bowers 1975: 6; The Age 6 February 1975: 5). A journalist at the conference commented on how 'depleted is the Party's drive towards fundamental social reform in Australia'. The ALP, he suggested, was 'less willing to interfere with the existing distribution of power in Australian society' than at any time in the previous decade (Haupt 1975: 1).

A more significant indicator of Labor's shift in office was the 1975-76 budget, which brought to an end Labor's 'expansionist phase' and aimed to cut spending and curb inflation (Whitwell 1986: 216; Davidson 1975: 9). For Strangio $(2002,364)$, it 'heralded the arrival in Australia of neoliberal economic government'. In delivering the budget, Treasurer Bill Hayden stated that its emphasis was on 'consolidation and restraint rather than further expansion of the public sector', and it was premised on the notion that inflation, not unemployment, was 'the nation's most menacing enemy': 'We are no longer operating in that simple Keynesian world in which some reduction in unemployment could, apparently, always be purchased at the cost of some more inflation ... More inflation simply leads to more unemployment' (House of Representatives Hansard, 19 August 1975: 53). Whereas Keynesianism's status as orthodoxy had allowed Labor to avoid having to choose between mainstream economics and state 
intervention to raise living standards, the discrediting of Keynesianism meant that Labor no longer enjoyed this luxury (Strangio 2002: 39). Where interventionist policies seemed to garner widespread support in the 1950s and 1960s, business opposition to the Whitlam government's reformist policies grew significantly in the midst of recession so that by 1975 business had 'declared war' on Labor (Connell 1977: 118; Strangio 2002: 273; Ghosh 1980: 230).

This, again, revealed the way in which social democratic policies were now regarded as antithetical to business interests, requiring a change in policy direction. Reformist social democratic ambitions now seemed to belong to a bygone era. In his speech to the 1977 national ALP conference, Whitlam insisted that the party's reforms would have to wait for an improvement in the economic climate:

The growth economy in the fities $[\mathrm{sic}]$ and sixties was both the means and the justification by which Labor could go to the electorate with promises of social reform through an expanded public sector ... The economy in the seventies is a different story ... We have to moderate our social goals both for the sake of the economy and for the sake of the programs themselves... And the challenge for this Conference is to frame and adapt our policies to meet a new set of economic conditions, a whole new set of constraints ... (Whitlam 1977a: 7, 8 , emphasis added)

This judgement contrasted with the optimism displayed by Whitlam in 1972. As Whitlam's speechwriter Graham Freudenberg $(1977: 222,223)$ recalled, in 1972 there was 'no sense at all of any deep sickness, in either the Australian economy or world capitalism'. According to Whitlam, Labor's aim was 'to finance our new programs from [economic] growth. But world-wide inflation and recession frustrated this objective' (Whitlam 1977b: 204). Whitlam argued in 1978 that reforms Labor had introduced in government such as free tertiary education could not have been undertaken in these new economic circumstances (Whitlam 1978: 28). One ALP delegate to the party's 1981 national conference complained that the economic crisis "undermined the whole basis of the sort of broad reform programme that the Labor Party has so frequently attempted to advocate in the past ...' (Robinson, cited in ALP 1981: 16). This explains the process of 'de-social-democratisation' which the party underwent in government in the 1980s and 90s (Burgmann 2004: 65).

\section{Conclusion}

There are undoubtedly differences in the way in which social democrats responded to the economic crisis that ended a quarter century of expansion following the Second World War. Yet, in all cases examined here, there 
was a marked retreat from reform, and a turn to policies aimed at boosting capital accumulation and freeing capital from government constraints. The abandonment of reformism was more abrupt in the cases of the SPD and ALP. Nevertheless, the return to slump in the world economy had implications everywhere for social democracy, which lost the economic base built up during the post-war period and could no longer offer policies that simultaneously met the needs of its working-class constituents and of capital accumulation.

Thus, the rapprochement with neo-liberalism is best understood as a response to changed economic conditions, which in turn shaped the ideological and political climates and put pressures on governments to open up their economies to cross-border flows of investment and trade, in the process creating the 'globalisation' many mistakenly credit with undermining traditional social democratic policies. In this sense, the end of the post-war boom provides an ultimate explanation, rather than the proximate explanation that globalisation may provide. Some will interpret this argument as economically determinist. In fact, given social democracy's historic commitment to the pursuit of reforms within capitalist confines, social democrats acted rationally in embracing neoliberal policies in a period of economic decline when the range of possible policy options narrows. Without a return to the economic growth levels of the post-war boom - an unlikely prospect - social democratic parties will not again implement redistributive policies reminiscent of that era. What seems clear is that the neo-liberalisation of social democracy is here to stay.

\section{Notes}

1 Detail of the evidence and arguments surrounding these explanations can be found in Lavelle (2008a, Ch. 3).

2 A variety of explanations have been put forward for the re-emergence of crisis in the 1970s. The author favours Marxist explanations based around the decline in the rate of profit internationally (see Harman 1984; Harris 1983, Ch. 3).

3 This followed the break-up of a 'grand coalition' with the Christian Democrats from 1966-69.

4 Announced in March 2003, the Agenda 2010 policy package included, among other things, legislation to limit the length of time for which an unemployed person could receive benefits; liberalisation of the law on wrongful dismissal for small firms; the addition of a 'sustainability factor' to pension provisions that took into account demographic changes; a rise in the retirement age; and employees taking on some of the cost of sickness benefit (Potthoff and Miller 2006: 404). For more on Agenda 2010, see Chapters 2 and 7 in this volume.

5 The SAP enjoyed uninterrupted rule between 1933-76. 
6 When the non-government-controlled upper house of parliament refused to pass Labor's budget, the Queen's representative, the governor-general, dismissed the government in November 1975. Fresh elections were held in December, and Labor was comprehensively defeated.

7 In theory the party's sovereign decision-making body but whose decisions in practice are often ignored by the party leadership, particularly when in government.

\section{References}

ALP (1981) Australian Labor Party 34th Biennial Conference, Melbourne, 27 July.

Ashman, S. (2003) 'The anti-capitalist movement and the war', International Socialism, 98, spring: http://pubs.socialistreviewindex.org.uk/isj98/ashman. htm.

Berger, S. (1994) The British Labour Party and the German Social Democrats: 19001931 (Oxford: Clarendon Press).

Birchall, I. (1986) Bailing Out the System: Reformist Socialism in Western Europe, 1944-1985 (London: Bookmarks).

Blair, T. and Schröder, G. (1999) The Third Way/Die Neue Mitte, a joint declaration by Tony Blair and Gerhard Schröder, 8 June.

Botton, G. (1970) 'Australia since 1939', in I. Griffin (ed.), Essays in Economic History of Australia (Milton: Jacaranda Press).

Bowers, P. (1975) 'Labor close ranks for an early election', Sydney Morning Herald, 7 February.

Brenner, R. (2002) The Boom and the Bubble: the US in the World Economy (London and New York: Verso).

Brezniak, M. and Collins, J. (1977) 'The Australian crisis from boom to bust', Journal of Australian Political Economy, 1, October.

Brown, G. (2003) Speech by the Chancellor of the Exchequer at the Global Borrowers and Investors Forum, 17 June: www.hm-treasury.gov.uk/newsroom_and_speeches/ press/2003/press_71_03.cfm.

Burgmann, V. (2004) 'Moloch's little mate: the ruling class and the Australian Labor Party', in N. Hollier (ed.), Ruling Australia: the Power, Privilege and Politics of the New Ruling Class (Melbourne: Australian Scholarly Publishing).

Callaghan, J. (2002) 'Social democracy and globalisation: the limits of social democracy in historical perspective', British Journal of Politics and International Relations, 4 (3), October.

Callinicos, A. (1997) 'Where does political power lie?’, Socialist Review, 206, March.

Carlsson, I. and Lindgren, A. (1998) What is Social Democracy? (Stockholm: Swedish Social Democratic Party).

Connell, R. W. (1977) Ruling Class Ruling Culture: Studies of Conflict, Power and Hegemony in Australian Life (Cambridge: Cambridge University Press).

Crisp, L. F. (1978) The Australian Federal Labour Party 1901-1951 (Sydney: Hale \& Iremonger).

Davidson, K. (1975) 'Hayden’s discipline starts at the top', The Age, 20 August. 
Driver, S. and Martell, L. (1998) New Labour: Politics after Thatcherism (Cambridge: Polity Press).

Dumenil, G. and Levy, D. (2004) Capital Resurgent: Roots of the Neoliberal Revolution (Cambridge: Harvard University Press).

Dyster, B. and Meredith, D. (1990) (eds) Australia in the International Economy in the Twentieth Century (Cambridge: Cambridge University Press).

Economist, The (2006) 'Admire the best, forget the rest', 7 September: www.economist.com/world/europe/PrinterFriendly.cfm?Story_id=7880173.

Eichel, H. (2000) 'Cutting taxes, strengthening growth, tackling unemployment', statement by Hans Eichel, Federal Minister of Finance, Bundespressekonferenz, 21 December: www.germany.info/relaunch/politics/speeches/122199.html.

Einhorn, E. S. and Logue, J. (2003) Modern Welfare States: Scandinavian Politics and Policy in the Global Age (Westport, Connecticut and London: Praeger).

Eley, G. (2002) Forging Democracy: the History of the Left in Europe, 1850-2000 (Oxford: Oxford University Press).

Federal Government (2004) Agenda 2010: Questions and Answers (Berlin: Press and Information Office of the Federal Government).

Fielding, S. (2003) The Labour Party: Continuity and Change in the Making of 'New' Labour (London: Palgrave Macmillan).

Freudenberg, G. (1977) A Certain Grandeur: Gough Whitlam in Politics (Melbourne: Sun Books).

Funk, L. (2000) 'Economic reform of Modell Deutschland', in R. Harding and W. E. Paterson (eds), The Future of the German Economy: an End to the Miracle? (Manchester: Manchester University Press).

Ghosh, S. (1980) 'Business and the Whitlam Government' in P. Weller andD. Jaensch (eds), Responsible Government in Australia (Richmond: Drummond Publishing).

Glyn, A., Hughes, A., Lipietz, A. and Singh, A. (1990) 'The rise and fall of the golden age', in S. A. Marglin and J. B. Schor (eds), The Golden Age of Capitalism: Reinterpreting the Postwar Experience (Oxford: Clarendon Press).

Hall, P. A. (1993) 'Policy paradigms, social learning and the state: the case of economic policymaking in Britain', Comparative Politics, April.

Harman, C. (1984) Explaining the Crisis: a Marxist Re-appraisal (London: Bookmarks).

Harris, N. (1983) Of Bread and Guns: the World Economy in Crisis (Harmondsworth: Penguin).

Harvey, D. (2005) A Brief History of Neoliberalism (New York: Oxford University Press).

Harvey, D. (2006) Spaces of Global Capitalism (London and New York: Verso).

Haupt, R. (1975) '1975 kills Labor's reforms', Australian Financial Review, 7 February.

Hayden, B. (1977) ‘Bill Hayden on the Economy’, H. V. Evatt Memorial Lecture, Adelaide University, 16 September.

Head, B. and Patience, A. (1979) 'Labor and liberal: how different are they?', in A. Patience and B. Head (eds), From Whitlam to Fraser: Reform and Reaction in Australian Politics (Oxford: Oxford University Press). 
Hobsbawm, E. (1994) The Age of Extremes: the Short Twentieth Century, 1914-1991 (London: Michael Joseph).

Hocking, J. and Lewis, C. (2003) 'Thirty years later: the Whitlam Government as modernist politics', in J. Hocking and C. Lewis (eds), It's Time Again: Whitlam and Modern Labor, (Armadale: Melbourne Publishing Group).

Huber, E. and Stephens, J. D. (1998) 'Internationalization and the social democratic model: crisis and future prospects', Comparative Political Studies, 31 (3): http://infotrac.galegroup.com.

Jahn, D. and Henn, M. (2000) 'The "new" rhetoric of New Labour in comparative perspective: a three-country discourse analysis', West European Politics, 23 (1), January.

Kelly, P. (1976) The Unmaking of Gough (Sydney: Angus \& Robertson).

Kesselman, M. (1982) 'Prospects for democratic socialism in advanced capitalism: class struggle and compromise in Sweden and France', Politics \& Society, 11.

Kitschelt, H. (2000) 'The German political economy and the 1998 election', in D. P. Conradt, G. R. Kleingeld and C. Soe (eds), Power Shift in Germany: the 1998 Election and the End of the Kohl Era (New York: Berghahn).

Kotz, D. M. (2001) 'The state, globalization and phases of capitalist development', in R. Albritton, M. Itoh, R. Westra, and A. Zuege (eds), Phases of Capitalist Development: Booms, Crises and Globalizations (Hampshire: Palgrave).

Lachman, D., Bennett, A., Green, J. H., Hagemann, R. and Ramaswamy, R. (1995) Challenges to the Swedish Welfare State (Washington, DC: International Monetary Fund).

Lafontaine, O. (2000) The Heart Beats on the Left (Cambridge: Polity Press).

Lavelle, A. (2008a) The Death of Social Democracy: Political Consequences in the 21st Century (Aldershot: Ashgate).

Lavelle, A. (2008b) 'The boom, the left and capitalism', Journal of Australian Political Economy, 61.

Lundberg, E. (1985) 'The rise and fall of the Swedish model', Journal of Economic Literature, 13, March.

McDougall, G. (1975) 'Business not as usual - and the market loves it', The Age, 30 January.

Maddison, A. (2001) The World Economy: a Millennial Perspective (Paris: OECD).

Madeley, J. T. S. (1999) ‘The 1998 Riksdag election: Hobson's choice and Sweden’s voice', West European Politics, 22 (1), January.

Minnerup, G. (1976) 'West Germany since the war', New Left Review, 99, September-October.

Moschonas, G. (2002) In the Name of Social Democracy: the Great Transformation, 1945 to the Present (London and New York: Verso).

Nason, D. (2007) 'Sub-prime crisis may trigger global meltdown', The Australian, 28 July: www.theaustralian.news.com.au/story/0,25197,22146420-643,00. html.

Norberg, J. (2006) 'Swedish models: the welfare state and its competitors', National Interest, 84, summer.

Notermans, T. (2000) 'Europeanization and the crisis of Scandinavian social 
democracy', in G. Robert, C. Ingebritsen and W. M. Jonathon (eds), Globalization, Europeanization and the End of Scandinavian Social Democracy? (New York: St Martin's Press).

Nuder, P. (2004) opening speech on 'the guidelines', by Pär Nuder, Finance Minister, The Intermediate Congress of the Swedish Social Democratic Party, Stockholm, 16-18 April.

O'Lincoln, T. (1993) Years of Rage: Social Conflicts in the Fraser Era (Melbourne: Bookmarks).

Ormonde, P. (1981) A Foolish Passionate Man: a Biography of Jim Cairns (Ringwood: Penguin).

Padgett, S. and Paterson, W. E. (1991) A History of Social Democracy in Postwar Europe (London and New York: Longman).

Paterson, W. E. (1986) ‘The German Social Democratic Party', in W. E. Paterson and A. H. Thomas (eds), The Future of Social Democracy: Problems and Prospects of Social Democratic Parties in Western Europe (Oxford: Clarendon Press).

Persson, G. (2004) speech by Göran Persson at a European political scientists conference in Uppsala. Prime Minister's Office, 14 April: www.sweden.gov.se.

Persson, G. (2005) 'Making globalisation work for all', OECD Observer Magazine, 27, April: www.sweden.gov.se.

Pollin, R. (2003) Contours of Descent: US Economic Fractures and the Landscape of Global Austerity (London and New York: Verso).

Pontusson, J. (1994) 'Sweden: after the golden age', in P. Anderson and P. Camiller (eds), Mapping the West European Left (London: Verso).

Potthoff, H. and Miller, S. (2006) The Social Democratic Party of Germany 18482005 (Bonn: Dietz).

Regierung Online (2003) 'Schroeder in New York: Agenda 2010 reforms will help attract investments', 24 November: www.bundesregierung.de.

Rydge's (1975) 'Gough doffs', March.

Ryner, J. Magnus (1998) 'Neo-liberal globalization and the crisis of swedish social democracy' EUI Working Paper, SPS, 98/4.

Ryner, J. Magnus (2004) 'Neo-liberalization of social democracy: the Swedish case', Comparative European Politics, 2.

Särlvik, B. (1977) 'Recent electoral trends in Sweden', in K. H. Cerny (ed.), Scandinavia at the Polls: Recent Political Trends in Denmark, Norway and Sweden (Washington, DC: American Enterprise Institute for Public Policy Research).

Schröder, G. (1998) 'Because we trust in Germany's vitality ...', policy statement by Gerhard Schröder, Chancellor of the Federal Republic of Germany, Bundestag, 10 November: www.germany.info/relaunch/politics/speeches/111098.html.

Schröder, G. (2003) 'The economy über Alles', Wall Street Journal, 30 December: www.germany.info/relaunch/politics/speeches/010904.html.

Schröder, G. (2004) 'Foreword', in Federal Government, Agenda 2010: Questions and Answers. Berlin: Press and Information Office of the Federal Government: www. bundesregierung.de.

Silvia, S. J. (2003) Reinventing the German Economy, Policy Report, 8 (American Institute for Contemporary German Studies: John Hopkins University). 
Sparks, C. and Cockerill, S. (1991) 'Goodbye to the Swedish miracle’, International Socialism, 51, July.

SPD (2003) 'The courage to reform', resolution passed by the Extraordinary Party Congress on 1 June, Berlin.

Stiglitz, J. (2003) The Roaring Nineties: Why We're Paying the Price for the Greediest Decade in History (London: Penguin).

Strangio, P. (2002) Keeper of the Faith: a Biography of Jim Cairns (Melbourne: Melbourne University Press).

Swedish Institute (2004) 'The Swedish economy', Swedish Institute, 10 November: www.sweden.se.

Swedish Institute (2006) ‘The Swedish economy’, fact sheet, June: www.sweden. se.

Treasury Department (2006) 'Reflections on the global economy and the Australian mining boom', Economic Roundup, Spring 2006: www.treasury.gov. au.Documents/1190/HTML/docshell.asp?URL=5_boom.asp.

Vartiainen, J. (1998) 'Understanding Swedish social democracy: victims of success?', Oxford Review of Economic Policy, 14 (1).

von Weizsäcker, E. U. (2005) personal interview with Ernst Ulrich von Weizsäcker, Member of the German Bundestag, Berlin, 13 April.

Watkins, S. (2004), 'A weightless hegemony: New Labour's role in the neo-liberal order', New Left Review, 25, January-February.

Webber, D. (1983) 'Combatting and acquiescing in unemployment? Crisis management in Sweden and West Germany', West European Politics, 6 (1), January.

Whitlam, E. G. (1977a) address by the Leader of the Opposition, the Hon. E. G. Whitlam, QC, MP, to the ALP 1977 National Conference, 5 July.

Whitlam, E. G. (1977b) On Australia's Constitution (Camberwell: Widescope).

Whitlam, E. G. (1978) 'On reform during recession: the way ahead', inaugural T. J. Ryan Lecture, University of Queensland, Brisbane, 28 April.

Whitwell, G. (1986) The Treasury Line (Sydney: Allen \& Unwin).

Williamson, J. (2002) 'Did the Washington consensus fail?', Outline of speech at the Center for Strategic and International Studies, Peterson Institute, 6 November: www.iie.com/publications/papers/print.cfm?doc=pub\&ResearchID $=488$.

Wolfe, A. (1978) ‘Review: has social democracy a future?', Comparative Politics, 11 (1), October.

Wood, A. (1975) 'Cabinet acts on spending plans', Sydney Morning Herald, 29 January.

Wood, A. (2007) 'Hazards Demand Prudence', The Australian, 28 November. 


\title{
Fiscal policies, social spending and economic performance in France, Germany and the UK since 1970
}

\author{
Norman Flynn
}

\section{Introduction}

This chapter looks at the post-1970 development of social policy, its fiscal implications and economic consequences in three European countries. Its purpose is to test a stereotypical 'left' proposition, formulated in defence of European social democracy against neo-liberalism, such as:

There is a 'European Social Model', incorporating a high level of social protection for unemployment and retirement, which, since 1973, has been threatened by various 'fiscal crises' and pressures from demographic changes, especially falling birth rates and increased longevity and from economic competition. Recent elections in Germany and France have ushered in governments determined to undermine the European model and replace it with a deregulated economy and unprotected workforce.

All parts of this stereotypical statement have credible negatives. The 'Europeanness' of welfare policy is neither sufficiently homogeneous (displaying big differences between countries and probably excluding some Mediterranean countries) nor sufficiently distinct, unless set against a small set of 'others' and including various similar non-European welfare regimes, including Australia, New Zealand, Canada and probably Japan. Even a relatively small group of 'European' welfare states has a wide variety of origins and characteristics. To defend a European style of welfare regime against a neo-liberal style is therefore to defend variety.

Fiscal pressures have followed the economic cycle, although possibly with growing amplitude, and have not yet resulted in an overall crisis, if such is defined as a failure or breakdown. Periodically, governments have been elected who try to reverse public spending growth and redesign welfare systems, whether in Scandinavia and the UK at the beginning of the 1980s, the Kohl governments in Germany through the 1980s and the Merkel government from 2005, or Sarkozy as Finance Minister and 
then President in France in 2007. Only the UK's Conservatives succeeded in producing a residualised state welfare system, especially in the areas of retirement pensions and unemployment compensation: the others have gradually increased retirement ages, reduced the generosity of benefits and tried to reduce the costs of unemployment compensation.

European economies are subject to shared competitive pressure, but have responded in different ways. Of the three major economies, Germany has gradually dismantled its consensual corporatism as companies swing towards shareholder returns and away from social responsibility and France has also slowly liberalised. Only the UK has created a liberal labour market and weak regulation. However, on economic indicators of national economic success, such as the competitiveness of exports, or labour productivity, France and Germany are consistently outperforming the UK, which survives on low productivity, long working hours and balance of payments deficits.

\section{Selective solidarity, corporatism and state welfare}

One of the difficulties in arguing for a 'European' model of social welfare provision is Europe's diversity. Gosta Esping-Andersen (1990) made an influential classification of OECD-member welfare regimes, which divided the world into three - the social democratic welfare state, the liberal democratic and the conservative corporatist. The UK was put in the liberal democratic camp, with France and Germany in the conservative corporatist. For our purposes, analysing differences, it is important to look at the differences between France and Germany as well as the similarities.

\section{Germany}

There is no doubt that Germany's pension, unemployment benefit and healthcare systems are generous by world standards. While the rhetoric of the critics may be exaggerated, since Konrad Adenauer's chancellorship, German citizens have benefited from high levels of benefits and have paid high levels of tax for them. Some commentators say that the scale and reach of the welfare state is unsustainable. The Süddeutsche Zeitung summarised this position:

The first German Chancellor (Bismarck) reacted to the old, rural welfare system that was partly family, partly feudal with a solution for the new citydwelling industrial working class. Sickness, accident and unemployment insurance would prevent the creation of a forgotten lumpen proletariat and undermine the basis for social revolution and coups.

The kernel of Bismarck's social policy was the insurance principle: participants in the labour process put a small share of their wages into a big welfare 
chest from which any needs would be met by a guaranteed payment of the claim.

The next radical effort needed another big Chancellor, Konrad Adenauer. After the Second World War he proved himself to be the protector of German solidarity with an astonishing expansion of access to compensation by guaranteeing wealth to those excluded from the consumer economy. At the height of the economic miracle, Adenauer converted the principle of 'burden sharing' to the principle of 'wealth sharing', setting up transfer mechanisms whereby pensioners and the unemployed share the general wealth of the country ... What Schröder and his people have begun is nothing less than leading the German welfare state from wealth-sharing to poverty-sharing. ${ }^{1}$ For future generations this welfare state must go back to its original purpose: insurance against the risk of basic hardships. ${ }^{2}$

There is a widespread view in Germany that the tax and benefit systems are in need of radical change and that the budget deficit will not be eradicated by future economic upturns. A thorough analysis appears in Kitschelt and Streeck (2004). The outline of the argument is this: the 'German system', a corporatist agreement on pay levels and company governance combined with high taxation and high levels of benefits, is under threat. Increasing openness of the economy makes it less possible for German companies to compete while absorbing high wages and the heavy tax and insurance contributions demanded by the welfare system. Trade union strength is waning and workers find it decreasingly possible to assert their welfare demands. Corporate governance has changed from a corporatist attitude, treating workers evenly with shareholders, towards objectives purely aimed at increasing profits and shareholder value.

At the same time, five factors have produced extra demands on the welfare and pension system: the longer than expected recession that generated high levels of unemployment; increasing profitability has been achieved by shedding labour, especially among the older workforce, who are entitled to pensions; demographic change also generates increasing pension demands; reunification was expensive as western levels of benefit entitlement were extended to the east while privatisation and exposure to competition produced a big increase in unemployment there.

These extra demands on the government's finances were met mainly by increases in the social security contributions of employers and employees and by borrowing. Unfortunately reunification was achieved at the start of a recession that depressed tax revenues.

The first Schröder Government (1998-2002) reversed some of the cuts in pensions, sick pay and disability benefits that the Kohl government had implemented. It also tried to make some cuts of its own, most notably in the replacement rate of the standard public pension, from 70 per cent to 
64 per cent by 2030 . At the beginning of its second term the government introduced the first of the so-called Hartz reforms to the labour market. Peter Hartz, personnel director of Volkswagen, chaired a commission to propose changes to the unemployment benefit system to try to reduce the disincentives for the unemployed to seek low-paid jobs. The reform (known as Hartz IV) involved changing the unemployment benefit system. Before Hartz IV unemployed people got 60 per cent of previous earnings (67 per cent for those with children) for thirty-two months, then 53-57 per cent for ever. Hartz IV does away with the second payment, replacing it with a flat-rate means-tested benefit of $€ 345$ per month plus a rent and heating allowance (€331 in the east). The new benefit is also conditional on claimants actively seeking work.

Hartz IV was part of a collection of policy shifts that were collected together at the end of 2003 in Agenda 2010, which contained changes in social welfare provision, taxation, education and training, research and labour market policies.

\section{France}

The French welfare state has its origins in the public medical insurance and pension scheme enacted in 1930. It was consolidated in 1945-46 and developed into a comprehensive and complicated welfare system. Families are the most important unit, receiving family benefits, child allowances and housing allowances. The family allowance, introduced in 1932, continued and was increased, partly because of concerns about falling birth rates and fears of an ageing population, and partly because of a policy designed to support nuclear families. Spending on family policy represents nearly half of social spending.

There is a mixture of insurance-based schemes for employees and state benefits for non-contributors. Pensions are state-backed but based on employer and employee contributions. The pension scheme has recently been under fiscal strain from early retirements and longevity. The main feature of the pension system is the existence of 'special funds' for occupational groups, such as transport workers and the professions in the public sector. About 30 per cent of the population is covered by one of the special funds, which absorb 60 per cent of France's pension costs. The thirty-six major special funds are all in deficit and subsidised by taxation. Successive French governments have tried to cut the spending on these subsidies, by increasing retirement ages and the number of years' contributions required before retirement pensions are paid. The reforms have been resisted by the unions representing the beneficiaries of these funds, which are embedded in their administration. Since 1995, there have been reform efforts and resistance, a process pursued by Juppé (1995-97), suspended during 
most of Lionel Jospin's term (1997-2002) and pursued again by Raffarin (2002-05) and then by Nicholas Sarkozy (2007-). Resistance to changes in the pension regimes is presented as 'solidaristic', despite the fact that the schemes themselves are exclusive (Smith 2004).

Workers' rights (especially the protection from dismissal and the 35-hour week) are also strong in France and there have been reform attempts and resistance over a long period (see Chapter 4 in this book). Some argue that the inflexibility of the labour market that results from these protections is a major cause of persistent high unemployment. There has been no concerted policy of reducing these rights equivalent to the Hartz proposals in Germany, although there are periodic efforts to change individual aspects, such as the 'first employment contract' changes proposed in 2006, which would have removed employment protection in the first two years' employment from workers under 25 years old, but was then dropped after mass protests.

\section{United Kingdom}

The welfare system in the UK has its origins in the Liberal governments of 1906-14, which introduced an unemployment insurance scheme and mutual health insurance societies. The health and unemployment insurance systems were consolidated at the end of the Second World War, providing a universal, free healthcare system, a universal state pension and unemployment benefits. While there is a National Insurance contribution by employers and employees, in practice these are treated exactly like other taxes and constitute a payroll tax. There is a universal pension at a flat rate, enhanced by an earning-related element for people who have paid National Insurance contributions. In practice, pensioners who have not paid contributions receive supplementary income and rent subsidy because the basic pension is so low. The rate of increase of pensions was pegged to inflation rather than incomes in the early 1980s and its real value eroded.

Unemployment benefits are time-limited to six months and are conditional on active job-seeking (the benefit is called 'Jobseeker's Allowance'). The long-term unemployed enter the social security system and also have to seek work and training. The health system is free at the point of use for most services (excluding dentistry) although a charge is made for drugs.

Conservative governments from 1979-97 made various attempts to cut public spending and reduce the scope of the state. Public housing was privatised by selling homes to tenants. State pensions were frozen in real terms to contain cost and to encourage people to make their own individual or company pension provision. The privatisation programme removed about two million workers, in nationalised industries, the 'industrial civil service' and public transport, from state-backed pension schemes. Various efforts 
were made to increase the incentive to work and increase the gap between incomes in low-paid jobs and on benefits.

The Labour governments from 1997 continued the 'welfare to work' changes to benefits, by introducing a tax credit for low-paid working families and increasing child allowances, further enhancing the incentive for unemployed people to take jobs even if they are low paid. Pensions were unpegged from inflation. From 1999-2007, government spending policy was expansionary, increasing capital spending to cover the backlog of building and maintenance, especially of hospitals and schools, and increasing service improvements, especially in healthcare and education. In the case of healthcare an explicit target of spending as a percentage of GDP was adopted to bring healthcare standards up to European levels.

\section{Comparing social spending}

Given the difference in unemployment rates and social policies among France, Germany and the UK, it might be supposed that the expenditure on 'social expenditure' would show big variations, and especially would be much higher in the high unemployment countries. Table 2.1 shows social expenditure and its components as a percentage of GDP in 1981, 1991 and 2001.

Table 2.1 shows that the UK social expenditure is 5 to 6 percentage points of GDP below France and Germany. The categories on which the UK spends less are health, unemployment and old age. The differences in health spending are easily explained: in France and Germany there are 3.3 doctors per 1,000 population while the UK has 2.1, with commensurate differences in associated health spending. ${ }^{3}$

If we look at unemployment benefits, we see that the French and German systems are more generous to unemployed people, especially in the first year of their unemployment. Table 2.2 summarises the unemployment benefits in the three countries and Table 2.3 shows the unemployment insurance rates.

It is clear that the salary-related unemployment benefits in France and Germany are more generous than the flat-rate payments in the UK and that the period over which benefits are paid are longer than the UK's six months. Both the French and German governments have expressed concern about the 'poverty trap', whereby there is only a small incentive for unemployed people to look for work because the difference in net income between benefits and salary is so small. To some extent the UK government ameliorated this incentive problem by maintaining some benefits for low-paid workers if they return to work after being unemployed. The "working families tax credit' that guarantees a minimum income for low-paid working parents gives people with children an incentive to take low-paid jobs. Reducing 
Table 2.1 Public social expenditure 1981-2001, as a percentage of GDP

\begin{tabular}{|c|c|c|c|c|}
\hline$\%$ of GDP & & 1981 & 1991 & 2001 \\
\hline \multirow[t]{3}{*}{ Total social expenditure } & UK & 19.5 & 21.1 & 21.8 \\
\hline & France & 22.2 & 27.2 & 28.5 \\
\hline & Germany & 23.7 & 24.9 & 27.4 \\
\hline \multirow[t]{3}{*}{ Old age } & UK & 6 & 7.8 & 8.1 \\
\hline & France & 8 & 9.6 & 10.6 \\
\hline & Germany & 10.1 & 10 & 11.7 \\
\hline \multirow[t]{3}{*}{ Survivors } & UK & 1.8 & 0.7 & 0.6 \\
\hline & France & 2 & 1.7 & 1.5 \\
\hline & Germany & 0.9 & 0.5 & 0.4 \\
\hline \multirow[t]{3}{*}{ Incapacity } & UK & 1.1 & 2.3 & 2.5 \\
\hline & France & 2.9 & 2.5 & 2.1 \\
\hline & Germany & 2.1 & 1.8 & 2.3 \\
\hline \multirow[t]{3}{*}{ Health } & UK & 5.2 & 5.3 & 6.1 \\
\hline & France & 6.1 & 6.7 & 7.2 \\
\hline & Germany & 7.1 & 7.1 & 8 \\
\hline \multirow[t]{3}{*}{ Family } & UK & 2.4 & 2.1 & 2.2 \\
\hline & France & 2.8 & 2.7 & 2.8 \\
\hline & Germany & 2.4 & 2 & 1.9 \\
\hline \multirow[t]{3}{*}{ Labour market } & UK & 0.6 & 0.5 & 2.2 \\
\hline & France & 0 & 0.9 & 2.8 \\
\hline & Germany & & 1.4 & 1.9 \\
\hline \multirow[t]{3}{*}{ Unemployment } & UK & 1.5 & 1 & 0.3 \\
\hline & France & 0 & 1.9 & 1.6 \\
\hline & Germany & 0.8 & 1.4 & 1.2 \\
\hline \multirow[t]{3}{*}{ Housing } & UK & 0.2 & 1.2 & 1.5 \\
\hline & France & 0.5 & 0.8 & 0.9 \\
\hline & Germany & 0.1 & 0.1 & 0.2 \\
\hline
\end{tabular}

Source: OECD database

the period over which unemployment benefits are paid to six months also encourages people back to work. The German government has reduced the period over which unemployment benefits are paid since the information in Table 2.2 was produced.

The OECD made a calculation of the net income difference for a typical working family between being unemployed and returning to work in 1999. The results are shown in Table 2.4. This information is given in GBP, FF and DM, as it was collected in the year before the introduction of the euro. A simplified way of expressing the relationship between earnings in work and earnings when unemployed is a single figure called the 'unemployment trap' (shown in Table 2.5). Eurostat defines this as follows: 'The unemployment trap measures what percentage of the gross earnings (from 
Table 2.2 Unemployment benefits (insurance system), 2002

\begin{tabular}{|c|c|c|c|c|}
\hline & Duration & Reference salary & Rate & Taxation \\
\hline UK & $\begin{array}{l}182 \text { days } \\
\text { maximum }\end{array}$ & $\begin{array}{l}\text { Lump-sum, } \\
\text { age-related }\end{array}$ & $\begin{array}{l}\text { Lump-sum, } \\
\text { age-related }\end{array}$ & Taxed \\
\hline France & $\begin{array}{l}\text { Age-related and } \\
\text { related to length } \\
\text { of employment; } \\
42 \text { months } \\
\text { maximum }\end{array}$ & $\begin{array}{l}\text { Average } \\
\text { monthly salary }\end{array}$ & $\begin{array}{l}\text { Fixed }+ \\
\text { proportional to } \\
\text { salary; } 57.4 \% \text { of } \\
\text { salary maximum }\end{array}$ & Taxed \\
\hline Germany & $\begin{array}{l}\text { Age-related and } \\
\text { related to length } \\
\text { of employment; } \\
32 \text { months } \\
\text { maximum }\end{array}$ & $\begin{array}{l}\text { Net average over } \\
\text { previous year; } \\
\text { ceiling }\end{array}$ & $\begin{array}{l}60 \% \text { of net } \\
\text { salary, } 67 \% \text { with } \\
\text { children }\end{array}$ & Not taxed \\
\hline
\end{tabular}

Source: Zoom 2003

Table 2.3 Unemployment insurance rates, 2002

\begin{tabular}{lcc}
\hline & $\begin{array}{c}\text { Payment rate as \% of } \\
\text { previous gross earnings }\end{array}$ & $\begin{array}{c}\text { Maximum benefit } \\
\text { (\$US terms) }\end{array}$ \\
\hline France & 76 & 60,184 \\
Germany & 60 & 30,890 \\
United Kingdom & Flat & 4,084 \\
\hline
\end{tabular}

Source: OECD Benefits and Wages Indicators, from OECD database (accessed 2002)

moving into employment) is "taxed away" by the combined effects of the withdrawal of benefits and higher tax and social security contributions' (Eurostat 2004). Table 2.5 is concerned with the bottom end of the labour market and shows the difference in tax treatment of low wages. Broadly it suggests that there is less incentive for an unemployed person to take a lowpaid job in Germany than in France and much less in France and Germany than in the UK. While there is no conclusive evidence that high marginal tax rates produce a disincentive to take low-paid jobs, government policy on benefits for the unemployed and net tax for the low paid are based on this idea in the UK, and increasingly so in France.

The difference between workers' take-home pay and what it costs to employ them, known as the 'tax wedge', consists of income tax and the socialsecurity contributions of employees and employers. Table 2.6 shows the tax wedge in 2003. The table shows the difference between take-home pay and the cost to employers at various ratios to the average productive wage. 


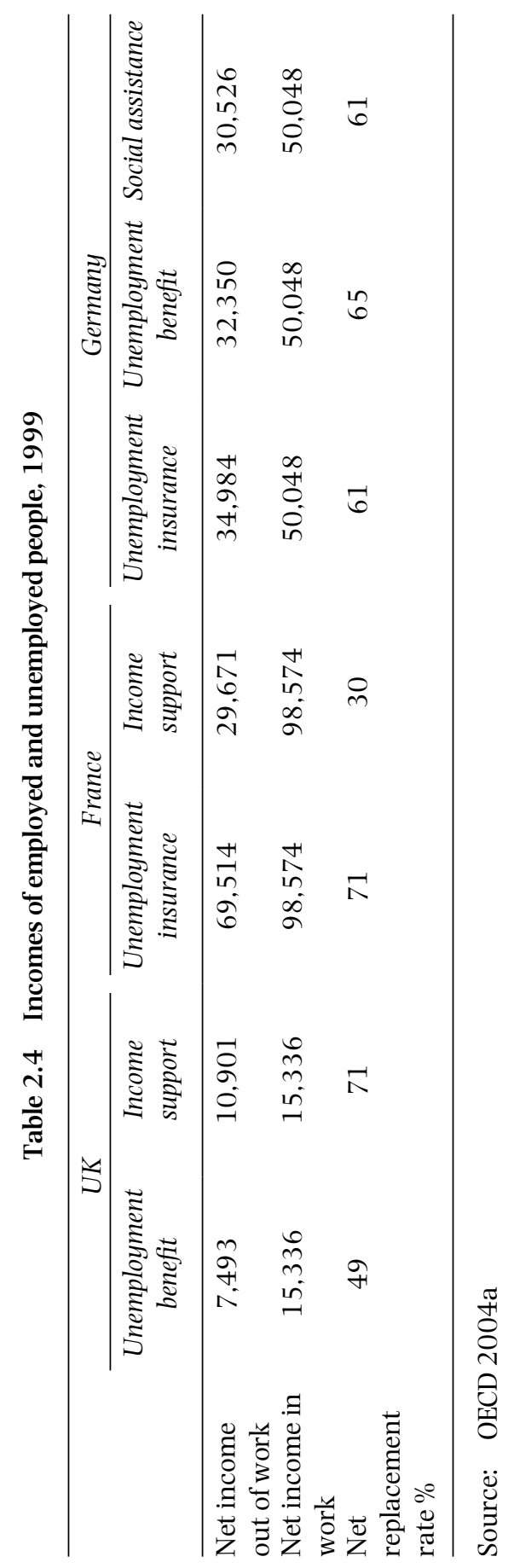


Table 2.5 Tax rate on low-wage earners: unemployment trap in 2002

\begin{tabular}{ccc}
\hline UK & France & Germany \\
\hline 71 & 83 & 87 \\
\hline
\end{tabular}

Source: Eurostat 2004: 146

Table 2.6 The tax wedge, 2003: marginal tax rates at income levels proportionate to the average productive wage

Total tax wedge 2003

\begin{tabular}{llrrr}
\hline \% of average productive wage & 67 & 100 & 133 & 167 \\
France & 74.1 & 52.5 & 53.8 & 53.8 \\
Germany & 59.8 & 65.3 & 61.5 & 67.4 \\
UK & 40.6 & 40.6 & 40.6 & 31.7 \\
\hline
\end{tabular}

Source: OECD database (accessed 2004)

Table 2.7 Unemployment as a percentage of the labour force, 2002-4

\begin{tabular}{cccc}
\hline & UK & France & Germany \\
\hline 2002 & 5.2 & 9.0 & 8.1 \\
2003 & 5.0 & 9.7 & 8.7 \\
2004 & 4.8 & 9.9 & 8.8 \\
\hline
\end{tabular}

Source: OECD 2004b

First, it is clear that employing relatively low-paid workers in France is an expensive undertaking. In Germany the bigger problem arises at the average and above average pay level. In the UK, with its cap on income tax and on social security contributions, the tax wedge is equal across the wage bands and lower than both France and Germany.

It is commonly said that the UK has a more flexible labour market than France and Germany. Payroll taxes are lower, firing is easier and therefore companies are more willing to hire labour. This results in lower rates of unemployment. It is certainly the case that unemployment rates are higher in France and Germany than in the UK. Table 2.7 shows comparative unemployment rates.

In Germany, the unemployment rate in the previous East German Länder is about twice the rate in the rest of the country.

\section{Public pensions}

Table 2.1 showed the difference in spending on old age. A large part of the explanation for this difference is the level of pensions as a proportion of 
Table 2.8 Pension ratios, 2000

\begin{tabular}{lcccc}
\hline & $\begin{array}{c}\text { Average pensioner } \\
\text { benefits: average } \\
\text { earnings }\end{array}$ & $\begin{array}{c}\text { Population } \\
\text { 65+:population } \\
16-64\end{array}$ & $\begin{array}{c}\text { Proportion of } \\
\text { 16-64-year-olds } \\
\text { working }\end{array}$ & $\begin{array}{c}\text { Pensioners per } \\
\text { worker }\end{array}$ \\
\hline France & 0.58 & 0.24 & 0.61 & 0.5 \\
Germany & 0.51 & 0.24 & 0.68 & 0.48 \\
UK & 0.20 & 0.24 & 0.73 & 0.4 \\
\hline
\end{tabular}

Source: Bongaarts 2004: Table 1

Table 2.9 Participation rates, 2002

\begin{tabular}{lccc}
\hline & UK & France & Germany \\
\hline Female & 65.3 & 56.7 & 58.8 \\
Male & 78.0 & 69.5 & 71.7 \\
Female 55-64 & 44.7 & 30.6 & 30.1 \\
Male 55-64 & 62.7 & 39.3 & 47.1 \\
\hline
\end{tabular}

Source: $\quad$ Metz et al. 2004

earnings. The UK ratio of pensioner benefits ${ }^{4}$ to average earnings in 2000 was 20 per cent while French and German pensioners received over half of average earnings. At that time there were no demographic differences, in the sense of the ratio of over-65-year-olds to those of working age. Table 2.8 shows the differences.

The difference in the dependency ratio arises from the employment levels among the working age population: early retirement in France and Germany has increased the ratio of pensioners per worker compared with the UK, rather than the age structure of the population. Table 2.9 shows participation rates (the percentage of the population who are either in work or seeking work) in the three countries in 2002.

The striking contrast is the higher participation rate of people aged 55 or over in the UK. A source of this difference in Germany is the shake-out as businesses sought to increase productivity from the mid-1980s on, combined with good levels of pension for the early retirers; in France, the generous pension system allows people to retire on good pensions after a relatively short working life.

What these snapshots of the three welfare systems show is that, on a world scale, the similarities among the three systems are more obvious than the differences: the settlement between labour and the state to provide tax and contribution funded social solidarity in old age and in periods of unemployment remains intact. The differences are in the levels 
of generosity of the solidarity payments, and in the conditions attached to such payments, given the differences in labour market regulation. The UK stands out as having a more flexible and less regulated labour market than the other two, while France has the most exclusive system of social solidarity and Germany has probably the most generous, especially to workers taking early retirement. These differences reflect the balance of power in the respective social democratic settlements: balanced towards the employers in the UK, to entrenched labour interests in France, and a residual corporatism in Germany, despite recent changes in government policy.

\section{Fiscal deficits, the economic cycle and crises}

National government budgets normally incur deficits at low points of the economic cycle, and many have persistent deficits. ${ }^{5}$ Some have "structural deficits', defined as the deficit at the top of the cycle: if tax revenues do not equal expenditure at the peak of the cycle, the deficit is more than cyclical. Structural deficits can result from consistent decisions to tax less than spending requires and from unanticipated expenditure requirements: unbudgeted for disasters such as floods, unplanned wars, and, in the case of Germany, the decision to reunite the country with a unified social welfare system and currency (the old 'East' Mark was given the value of the 'West' Mark). More gradual changes, such as the demographic effects of greater longevity and lower birth rates, can also lead to long-term deficits if commensurate adjustments to tax rates and entitlements are not made.

The Treaty of Maastricht of 1992 included provisions for harmonising the economic and monetary policies of EU member governments (articles 99-104). The four policy areas were: interest rates, inflation, government budget deficits and accumulated indebtedness. The Growth and Stability Pact (GSP) of July 1997 set out the maximum acceptable level of deficit for euro countries at 3 per cent of GDP, with the three non-euro EU members (UK, Denmark and Sweden) agreeing also to converge on this fiscal rule.

The idea of a common fiscal stance was pressed especially by the German government to try to instil some discipline in the taxation and spending policies of governments whose currencies had previously been less strong than the Deutsch Mark. In practice, several governments failed to comply with the rules: first Ireland, in 2002, and then Portugal, Germany and France. The pact was relaxed in March 2005. While the criteria of a maximum deficit of 3 per cent of GDP and maximum debt of 60 per cent of GDP remained in place, the rules were changed to allow exceptions to be tolerated and to not be met with sanctions. The exceptions include potential growth rates, the economic cycle, policies on pensions and social security, 
Table 2.10 Total tax revenue as a percentage of GDP, 1975-2003

\begin{tabular}{lccccccc}
\hline & 1975 & 1985 & 1995 & 2000 & 2001 & 2002 & 2003 \\
\hline UK & 35.3 & 37.7 & 35.0 & 37.4 & 37.2 & 35.8 & 35.3 \\
France & 35.9 & 43.8 & 43.9 & 45.2 & 44.2 & 44.0 & 44.2 \\
Germany & 35.3 & 37.2 & 38.2 & 37.8 & 36.8 & 36.0 & 36.2 \\
\hline
\end{tabular}

Source: Revenue Statistics 1965-2003, OECD 2004a: 18

Table 2.11 Taxes on income and profits as a percentage of GDP, 1975-2003

\begin{tabular}{lrrrrrrr}
\hline & 1975 & 1985 & 1995 & 2000 & 2001 & 2002 & 2003 \\
\hline UK & 15.8 & 14.6 & 12.8 & 14.6 & 14.7 & 13.5 & 12.9 \\
France & 5.7 & 7.0 & 7.1 & 11.2 & 11.3 & 10.5 & 10.2 \\
Germany & 12.1 & 12.9 & 11.6 & 11.4 & 10.6 & 10.1 & 9.9 \\
\hline
\end{tabular}

Source: Revenue Statistics 1965-2003, OECD 2004a: p.19

reforms and fiscal policy towards the management of debt levels over the cycle. While not abandoning the pact, the new agreement weakened its impact, to the extent that the Governing Council of the European Central Bank expressed serious concern over the future sustainability of public finances in the eurozone. It was an important recognition that budget balances are subject to cyclical and other influences.

Before looking at the reasons for the deficits in France and Germany, we look at the overall level of taxation in the three countries. Over the past three decades, there have been fairly consistent levels of taxation in the UK and Germany, expressed as a percentage of GDP. The exception is France, which added about 8 per cent of GDP to its tax take between 1975 and 1985. With respect to taxes on incomes and profits, the UK collects more than the other two as a percentage of GDP. Tax revenues and taxes on incomes and profits as a percentage of GDP are shown in Tables 2.10 and 2.11.

\section{Germany}

German federal fiscal policy treats the deficit as if some of it is 'structural' in the sense that the deficit does not clear at the peak of the economic cycle. There have been various attempts to hold back the demand on the social security and pension systems. The Kohl governments (1982-98) raised the retirement age, indexed pension increases to net rather than gross wage levels and undertook other adjustments to pension entitlements. Further efforts to cut spending included: reducing wage replacement rates for the unemployed; limiting social security payments to asylum seekers; and sick pay was reduced from 100 per cent to 80 per cent of normal earnings. 
Table 2.12 Public finances in Germany, 1970-2003

\begin{tabular}{lrrrr}
\hline$€ m$ & Expenditure & Revenue & $\begin{array}{r}\text { Financial } \\
\text { balance } \neq\end{array}$ & Net borrowing \\
\hline 1970 & 100,382 & 96,279 & $-4,081$ & 3,222 \\
1980 & 379,188 & 352,796 & $-26,505$ & 27,659 \\
1990 & 585,228 & 557,977 & $-27,147$ & 37,120 \\
$1991^{\dagger}$ & 721,855 & 667,840 & $-53,902$ & 58,663 \\
1992 & 827,636 & 765,032 & $-62,618$ & 55,414 \\
1993 & 866,052 & 797,472 & $-68,206$ & 67,809 \\
1994 & 909,381 & 850,885 & $-58,670$ & 46,426 \\
1995 & 950,523 & 889,492 & $-60,931$ & 48,970 \\
1996 & 962,546 & 894,310 & $-68,017$ & 56,855 \\
$1997^{*}$ & 961,220 & 916,520 & $-45,076$ & 50,987 \\
1997 & 921,798 & 876,581 & $-45,567$ & 50,848 \\
1998 & 932,704 & 906,549 & $-25,981$ & 32,705 \\
1999 & 951,294 & 929,935 & $-21,963$ & 31,747 \\
2000 & 960,788 & $979,322^{\S}$ & 18,552 & 19,763 \\
2001 & 975,465 & 925,600 & $-49,768$ & 6,532 \\
2002 & 987,072 & 920,353 & $-66,299$ & 45,467 \\
2003 & $1,000,980$ & 926,334 & $-74,487$ & 62,907 \\
\hline
\end{tabular}

Source: Federal Statistics Office, Germany (accessed 2004)

Key $\quad *$ Revenue less expenditure incl. internal offsetting. Not identical to government budget deficit in national accounts

TFrom 1991 data refer to the FRG post-3 October 1990

"In 1997 hospitals with commercial accounts and the supplementary funds for public employees were excluded from the accounts

\$Includes revenue from sale of mobile phone licences

At the same time, demands on spending continued to grow, especially through long-term care insurance for the elderly (introduced in 1994), continuing early retirements and wage subsidies designed to cut unemployment in the east.

In two of the biggest deficit years some of the deficit was partly caused by technical bad luck: the accounts for 1995 show debt service charges for the unification debt in the main government accounts for the first time, while in 1996 court rulings raised income tax thresholds and shifted mining subsidies from fuel bills to the government account.

Table 2.12 shows net borrowing growing again in 2003 , to $€ 62.9$ billion, of which $€ 38.6$ was accounted for by the Federal government. The 2004 budget estimated federal net borrowings of $€ 29.3$ but the likely out-turn was $€ 10$ billion higher than that partly because of lower than expected tax revenues and partly because of higher spending on labour market polices. 
Tax revenues were predicted to fall again in 2005 and thereafter recover through to 2008. Achieving the GSP level of deficit is heavily dependent on the tax revenue growth assumptions: +4 per cent in 2006 and +3.8 per cent in 2007, with corresponding spending growth held to +1.8 per cent and +1.4 per cent. This is especially difficult given that income tax rates have been progressively reduced. Between 2000 and 2005 the top rate of tax was cut from 53 per cent to 42 per cent and the bottom rate from 26 per cent to 15 per cent (Agenda 20102004 ).

As Siebert has suggested: 'It is fair to say that the budget deficits are not caused by a spending spree... A major factor in the budget deficits is the poor showing of tax revenue' (2004: 38 ). The problem may be that the economic recovery (growth returned in the second half of 2003) did not result in a proportionate increase in tax revenues. If companies are more able to avoid corporate taxes, while the rates of income tax are cut, then the proportion of the deficit that is structural will increase and the government will not be able to reduce its deficit to the GSP prescribed level. Meanwhile, the government continues to prop up the current deficit with privatisation proceeds (Agenda 2010 2004). The German government finally reduced the deficit to 2.5 per cent of GDP in the second half of 2006 (Statistisches Bundesamt Deutschland 2006).

The German deficit was the product of a series of events: company restructuring produced a large number of redundancies of workers who became pensioners at an early age with large pensions; reunification without economic transformation in the east; tax cuts; and electoral resistance to benefit reductions. While there are efforts to contain entitlements, especially for the unemployed, there is as yet no sign of a dismantling of the welfare system.

\section{France}

Demands for spending have resulted in a persistent budget deficit that remains at 1.5-2 per cent of GDP even at the top of the economic cycle. The French deficit also follows the economic cycle. Figure 2.1 shows that the French cycle is roughly synchronised with the German, peaking in the mid1990s, then beginning to rise again after 2000. By 2002 the deficit had crossed the GSP threshold of 3 per cent of GDP and did so again in 2003.

In 2003 France received a mission from the International Monetary Fund for an Article IV consultation (International Monetary Fund 2003). The IMF approved of the French government's plans to cut the deficit in the medium term. In response to the problem of population ageing and the desirability of cutting taxes the IMF said that that the government should aim for a small structural surplus 'within the next five years' and cut the size of the outstanding debt. 


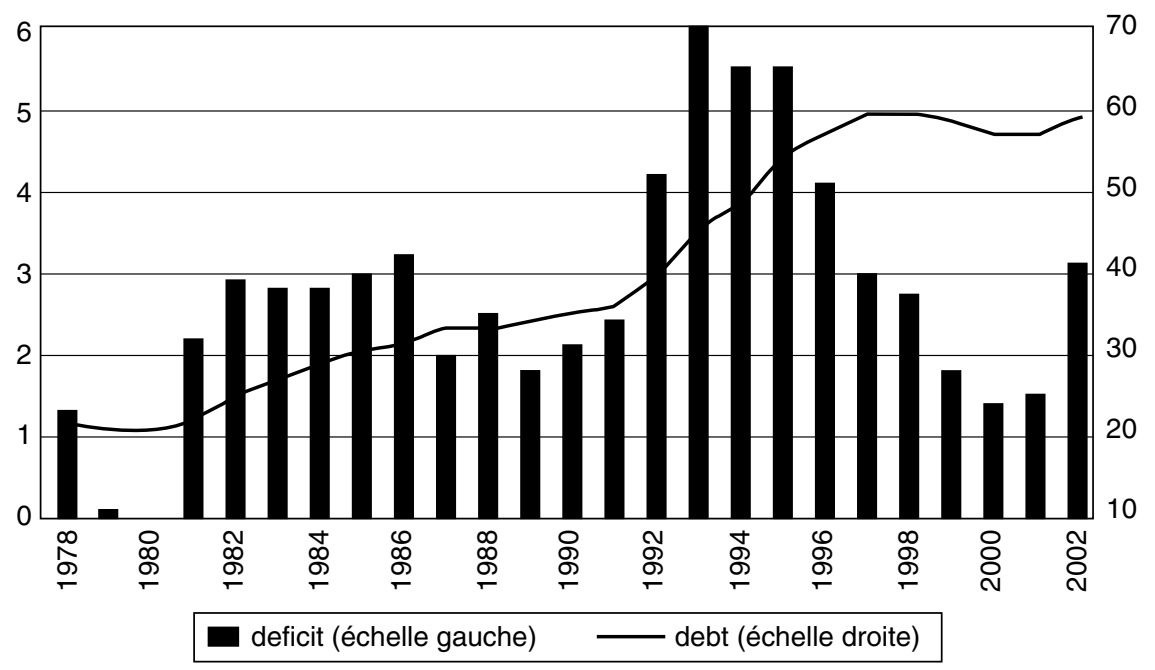

Figure 2.1 Evolution of the public sector deficit and the French public sector debt, 1978-2002, as a percentage of GDP

Source: Ministry of Finance 2003

Key échelle gauche $=$ left-hand scale; échelle droite $=$ right-hand scale

The 2005 French budget started the process of expenditure cuts to conform to the GSP target of a deficit of less than 3 per cent of GDP. The outgoing Minister of Finance, Nicolas Sarkozy, introduced the biggest deficit reduction in a single year that had ever been achieved, from $€ 57 \mathrm{bn}$ in 2003 to $€ 45 \mathrm{bn}$ in 2005 , or 2.9 per cent of GDP, just within the GSP threshold. The main features of the budget were a ritual net cut of 7,188 civil service and public sector jobs and sweeteners of $€ 2$ billion in tax cuts, $€ 0.9$ billion to households and $€ 1.1$ billion to companies. The reduction of the deficit relied on two factors: an economic growth rate of 2.5 per cent in 2004 and 2005 (compared with a eurozone forecast of 1.9 per cent and 2.2 per cent) to raise the level of taxes collected; and a one-off windfall of $€ 7$ billion from the transfer of the EDF and GDF (the electricity and gas companies) pension funds to the social security fund, a sum amounting to 0.4 per cent of GDP. Without this windfall, the projected deficit for 2005 would have been 3.3 per cent of GDP (Le Monde, 22 September 2004). The 2005 budget also introduced some selective tax cuts, reducing the top rate of income tax from 49.58 per cent to 48.09 per cent, increasing tax allowances for home workers and for social security claimants who find jobs, and used tax levels to cut smoking and driving.

The persistent French deficit from 2003 was the product of a fall in the amount of tax collected and an increase in spending, especially on health 
and social security. In 2002, the increase in the social security fund deficit added 0.3 per cent of GDP to the budget. The following year, the deficit on the health insurance budget increased from $€ 6.1 \mathrm{bn}$ to $€ 10.6 \mathrm{bn}$, mainly because of growth in prescribed medicines and general use of healthcare. The government changed both social security and health insurance systems to try to get spending under control. The Council of the European Union closed the deficit procedure in January 2007, announcing that the deficit had finally fallen below 3 per cent of GDP (Council of European Union 2007).

On the definition of structural deficit related to the deficit at the top of the cycle, the French government probably has roughly a 2 per cent structural deficit and a 1-2 per cent cyclical deficit in recession. Demographic trends and the likelihood of persistent unemployment imply a demand for a steady increase in benefit payments at existing levels and entitlement definitions. Unless taxes are raised in proportion, the deficit will return. Gradual reductions in entitlements and benefit levels are the other option to contain the deficit. However, as in Germany, the number of voters who stand to lose from lengthening working life and reducing benefits is large and resistance likely.

\section{United Kingdom}

Table 2.13 shows UK public sector receipts and expenditure from 1970 to 2002. There is a cyclical pattern to the deficit and a consistent surplus was recorded by the Labour government from 1997/8 onwards. This allowed the chancellor to pay off debts and reduce the outstanding debt and current debt payments. In 2002/3 (beyond the table) the account went into deficit for the first time since 1997. Between April and October the public sector recorded a deficit of $£ 17.2$ billion (Office for National Statistics 2004).

The UK government increased public spending up to 2007, especially on services rather than benefits. Its deficit is just within the GSP criteria. Increased spending, especially on education and healthcare, indicates a move towards more European norms, rather than away from those values.

These trends therefore show: there are cyclical variations in budget deficits in all three countries; that Germany and France both seem to have structural deficits that do not clear at the top of the cycle; and that the French and German governments, while taking steps to reduce deficits, have other priorities than a balanced budget, whatever the Maastricht Treaty requirements might be. The UK has cyclical deficits but attempts to balance the government budget over a whole economic cycle. What the trends do not show is evidence of a big 'fiscal crisis of the state' or a need to dismantle social policies in a radical way. 
Table 2.13 United Kingdom, public sector receipts and expenditure, 1970-2002 (fm)

\begin{tabular}{lccc}
\hline Year & Current expenditure & Current receipts & Receipts less expenditure \\
\hline 1970 & 16,899 & 22,618 & 5,719 \\
1980 & 92,567 & 97,639 & 5,072 \\
1990 & 199,716 & 218,255 & 18,539 \\
1991 & 220,980 & 225,729 & 4,749 \\
1992 & 244,221 & 227,629 & $-16,592$ \\
1993 & 258,163 & 230,508 & $-27,655$ \\
1994 & 272,463 & 249,416 & $-23,047$ \\
1995 & 285,489 & 270,247 & $-15,242$ \\
1996 & 294,167 & 283,839 & $-10,328$ \\
1997 & 304,370 & 305,026 & 656 \\
1998 & 312,153 & 331,850 & 19,697 \\
1999 & 322,871 & 350,412 & 27,541 \\
2000 & 342,878 & 375,043 & 32,165 \\
2001 & 361,533 & 391,118 & 29,585 \\
2002 & 385,940 & 393,925 & 7,985 \\
\hline
\end{tabular}

Source: Office for National Statistics 2004

\section{Global competition, the competitive state and economic performance}

The picture presented above is one of variation in social spending and variation in the size of the public sector deficit, although all three countries operate within a shared, broadly social democratic framework. In this section we look briefly at differences in economic performance: the question is whether the less generous levels of social benefits, and relative fiscal prudence, have generated better economic performance in the United Kingdom than in its two main European competitors.

\section{Trade competitiveness}

The first set of evidence focuses on trade competitiveness. Trade statistics are available on the WTO database. Table 2.14 shows imports and exports of merchandise and services for the world's biggest trading countries in 2003. The data show that the USA is the world's biggest exporter of the sum of merchandise and services, followed by Germany, Japan, China, France and the UK. In merchandise exports, Germany is ranked first, followed by the USA, with France fifth and the UK sixth. For service exports (mainly banking and insurance) the UK is second after the USA, Germany third and France fourth. Germany's merchandise exports are 236 per cent of those of the UK and nearly twice as big as France's. Germany's problems of inflexibility and high tax are not yet reflected in a poor balance of payments performance. 


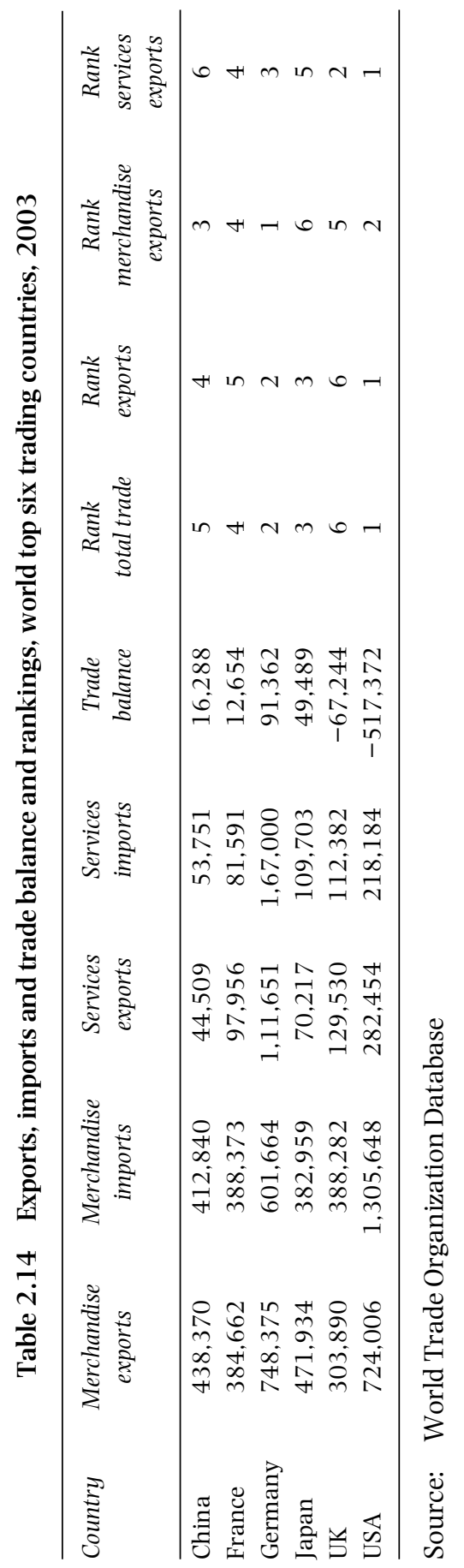


Table 2.15 GDP and GDP per head, 2003

\begin{tabular}{lcrrrc}
\hline & & UK & France & Germany & Unit \\
\hline Eurostat & GDP/head & 26,490 & 25,280 & 24,080 & Euro \\
OECD & GDP & 1,720 & 1,709 & 2,171 & $\begin{array}{c}\text { \$US at purchasing } \\
\text { power parity }\end{array}$ \\
OECD & GDP/head & 29,000 & 27,800 & 26,300 & \$US \\
\hline
\end{tabular}

Sources: Eurostat Yearbook 2004 and OECD in Figures 2004

These merchandise export figures do not show a picture of a sluggish Germany and France and a nimble, flexible UK. It is also unlikely that the positive UK performance in banking and insurance exports is a result of a flexible labour market and the low costs of employing banking and insurance labour.

If we look at trade balance, Germany had a healthy surplus, at 10 per cent of exports; France had a positive balance of 2.6 per cent of exports; the UK had a trade deficit of 15.5 per cent of the value of exports.

\section{Gross Domestic Product}

A common measure of economic performance is the size and growth rate of Gross Domestic Product (GDP), measured both by the value of goods and services produced and the value of incomes derived from producing them. Comparative GDP suffers from the problem of how national currencies are valued. One solution to this is to measure in common purchasing powerwhat the incomes could buy, rather than converting them at the exchange rate.

As shown in Table 2.15, the GDP figure puts the UK a whisker ahead of France, making the UK the fourth biggest economy on this measure (after the USA, Japan and Germany). For GDP per head the three countries are very close, with the UK ahead of France and Germany according to both sources. However, the UK had faster GDP growth in the decade to 2003, as shown in table 2.16. By 2008, UK GDP per head was estimated by Oxford Economics (2008) to be $£ 23,500$, France $£ 21,700$ and Germany $£ 21,665$. This contrasts with 1974, when UK GDP per head was 83 per cent of that of France and 96 per cent that of Germany.

\section{Direct investment flows}

The argument about tax levels and investment is that low tax attracts inward investment (and encourages domestic investment). A "competitive state' takes notice of the impact of taxation decisions on companies' investment location decisions. 
Table 2.16 Average annual volume change in GDP as a percentage, 1993-2003

\begin{tabular}{ccc}
\hline France & Germany & UK \\
\hline 2.1 & 1.4 & 2.9 \\
\hline
\end{tabular}

Source: OECD 2004a

Table 2.17 Investment flows, 1993 and 2003

\begin{tabular}{|c|c|c|c|c|c|c|c|}
\hline & & $\begin{array}{c}\text { Billion } \\
\text { \$US }\end{array}$ & $\%$ GDP & $\begin{array}{c}\text { Billion } \\
\$ U S\end{array}$ & $\%$ GDP & $\begin{array}{c}\text { Billion } \\
\$ U S\end{array}$ & $\% G D P$ \\
\hline & & \multicolumn{2}{|c|}{ UK } & \multicolumn{2}{|c|}{ France } & \multicolumn{2}{|c|}{ Germany } \\
\hline \multirow[t]{2}{*}{ Inflows } & 1993 & 14.8 & 1.54 & 16.4 & 1.29 & 0.4 & 0.02 \\
\hline & 2003 & 14.6 & 0.81 & 45.3 & 2.6 & 12.9 & 0.54 \\
\hline \multirow[t]{2}{*}{ Outflows } & 1993 & 26.1 & 2.71 & 19.7 & 1.55 & 17.2 & 0.88 \\
\hline & 2003 & 55.3 & 3.08 & 55.2 & 3.17 & 2.6 & 0.11 \\
\hline
\end{tabular}

Source: OECD 2004a

Table 2.17 shows investment inflows and outflows of the three countries in 1993 and 2003. Clearly the UK and France had a net outflow of direct investment in both years. Germany has small flows in both directions. In 2003 France had more than three times the volume of direct inward investment than the United Kingdom. Also notable in Table 2.17 is the contrast between the large outflows of investment from the United Kingdom and France and the very small outflow from Germany. This probably reflects high levels of portfolio investment from the UK and investment in infrastructure by French public utility companies, while German profits are reinvested in Germany.

\section{Manufacturing output}

Statisticsshow that since 1997 manufacturing outputin Franceand Germany diverged from that of the UK. While output in all three countries declined after 2000 , the decline was faster in the UK than in the other two. Is this a paradox? The economy that responds to global pressure by keeping taxes and benefits low is the least successful in maintaining its manufacturing sector?

\section{Productivity and working hours}

Table 2.18 shows that the high GDP per head is partly due to the fact that more people are working in the UK, especially workers over 55 years old. Those in work also work longer hours. Table 2.18 shows the average hours worked per person in employment. UK workers of working age put in about 
Table 2.18 Hours worked per person in employment, 2002

\begin{tabular}{lccc}
\hline & UK & France & Germany \\
\hline All workers & 1707 & 1459 & 1444 \\
Workers 15-64 & 1221 & 946 & 934 \\
\hline
\end{tabular}

Source: Metz et al. 2004

Table 2.19 Productivity, 2002

\begin{tabular}{lccc}
\hline & UK & France & Germany \\
\hline GDP per worker & 100 & 112.9 & 98.8 \\
GDP per hour worked & 100 & 131.7 & 116.4 \\
\hline
\end{tabular}

Source: $\quad$ Metz et al. 2004

Table 2.20 Labour costs, euros per hour, 2004

\begin{tabular}{lcc}
\hline & Industry & Services \\
\hline Germany & 30.23 & 24.07 \\
France & 26.90 & 30.60 \\
UK & 24.99 & 24.45 \\
\hline
\end{tabular}

Source: European Commission 2006

30 per cent more hours than their French and German counterparts. Both France and Germany have policies of reducing working hours as a way of combating unemployment and hours worked have fallen since 2000.

Table 2.19 shows indices of productivity: GDP per worker and GDP per hour worked. While UK workers put in more hours, the value of their output per hour worked is probably 30 per cent less than that of their French counterparts and 16 per cent less than the Germans. One interpretation of these figures is that unemployment in France and Germany would reduce to UK levels if German and French workers were much less productive and willing to work longer hours for lower pay. In other words the employment 'success' of the UK is underpinned by low productivity combined with low pay. Table 2.20 shows comparative labour costs in manufacturing and services in the three countries in 2004: the UK is lowest in manufacturing and roughly the same as Germany in services.

\section{Conclusions}

The twin perils of globalised competition and population ageing may prove damaging to European welfare states, but up to now there has been no 
event that could be called a crisis. France and Germany have relatively high unemployment and structural fiscal deficits and both governments are attempting adjustments to their welfare regimes and labour markets to enable both unemployment and deficit levels to be lowered. The UK has a less generous welfare state and more flexible labour market than either France or Germany, but its workers put in an average of 30 per cent more hours and are on average 20 per cent less productive than their French and German counterparts. In both unemployment and retirement their benefits are significantly less generous that those of their European neighbours.

In economic performance, the UK has faster GDP growth and higher GDP per head from 2003, but also has a much larger net outflow of investment than France or Germany and a big negative trade balance, compared with the trade surpluses of France and Germany. The policy of low taxation and low benefits has not resulted in big net inflows of investment, nor a more successful trading economy.

What are the implications for the future of the social democratic project in these three countries? The settlement between capital, labour and the state can no longer, if it ever could, deliver social solidarity, wage restraint and a regulatory environment favourable to national capital. The freer movement of both capital and labour and the competition from nonwelfare states in industrial products clearly have an impact on the ability for national bargains to hold. However, the trends of the three decades from 1970 are surprising not because of the collapse of the social democratic model but because of its persistence. There are three reasons why the European model has not yet collapsed. First, the persistent competitiveness of manufacturing industry in France and Germany (along with other European social democracies) and some service sectors in the UK have enabled businesses in the successful sectors to continue to pay taxes and not participate in a 'race to the bottom' in wage levels or taxes. Second, the EU still provides protection for European business against completely free competition from low-wage economies, both in agricultural produce and manufactured goods. Third, the high levels of GDP per head leave room for bargaining over the distribution of that income among wages, profits and taxes. While the balance among these three will vary over time and according to the relative bargaining strengths of capital and labour, as we have seen in this chapter, pressures from global capital, commodity and labour flows have not yet, at least, tipped the balance entirely towards capital.

\section{Notes}

1 The German word I have translated as 'poverty-sharing' is Notgemeinschaft.

2 Süddeutsche Zeitung, 187, August 2004, author's translation. 
3 Figures for 2003, from OECD 2004a, Table 8.

4 In addition, there are means-tested benefits.

5 In the forty years to 2000, the US government had an average deficit of 2 per cent, for example (Schick 2000).

\section{References}

Agenda 2010 (2004) (German Federal Government, English translation).

Bongaarts, J. (2004) Population Aging and the Rising Cost of Public Pensions (Geneva: Population Council, Working Paper No. 185).

Council of European Union (2007) press release, 30 January.

Esping-Anderson, G. (1990) The Three Worlds of Welfare Capitalism (Princeton: Princeton University Press).

European Commission (2006) Key Figures on Europe (Brussels: Europe Commission).

Eurostat (2004) Eurostat Yearbook, the Statistical Guide to Europe (Brussels: Eurostat).

Federal Statistics Office, Germany (Statistisches Bundesamt): www.destatis.de.

International Monetary Fund (2003) France: 2003 Article IV Consultation Concluding Statement of the Mission, 30 June.

Kitschelt, H. and Streeck, W. (2004) Germany: Beyond the Stable State (London: Frank Cass).

Metz, R., Riley, R. and Weale, M. (2004) 'Economic performance in France, Germany and the United Kingdom: 1997-2002', National Institute Economic Review, 188, April.

Ministry of France (2003) 'Dépenses Publiques et déficit Fiscale' Paris: Documentation Française.

OECD (2004a) OECD in Figures.

OECD (2004b) Economic Outlook, 75.

OECD Database: www.sourceoecd.org.

Office for National Statistics (2004) Selected Financial Statistics, 5.4.

Oxford Economics (2008) 'UK GDP per capita to overtake US in 2008 for first time since the 19th century', press release, 7 January.

Schick, A. (2000) The Federal Budget: Politics, Policy, Process (Washington, DC: Brookings Institution Press).

Siebert, H. (2004) Germany's Fiscal Policy Stance, Kiel Working Paper 1196, (Kiel: Institute for World Economics).

Smith, T. B. (2004) France in Crisis (Cambridge: Cambridge University Press).

Statistisches Bundesamt Deutschland (2006) press release, 15 July: www.destatis. de.

World Trade Organization Database: http://stat.wto.org.

Zoom (2003) 'European and international unemployment systems: trends and development, status report as at 31.12.2002': http://info.assedic.fr/assurance_ chomage/travail/documents/ZOOM2003-Angl.241-348.pdf. 


\title{
From The Future of Socialism (1956) to a future without socialism? The crisis of British social democratic political economy
}

\author{
Noel Thompson
}

\begin{abstract}
The national shift to the left, with all its implications for the balance of power, may be accepted as permanent . . . Any Government which tampered seriously with the basic structure of the full-employment Welfare State would meet with a sharp reverse at the polls ... It is this which explains the otherwise curious phenomenon that the Conservatives now fight elections largely on policies which twenty years ago were associated with the left, and repudiated by the right ... The fact that the political battle today is waged mainly on ground chosen by the left is remarkable evidence of the change in national ideology ... (C. A. R. Crosland, The Future of Socialism, 1956: 28-9, 61)
\end{abstract}

While it may be read in other ways, The Future of Socialism can be seen as a paean to the ascendancy of Keynesian social democracy. In Crosland's view of things, demand management had delivered full or near-full employment; affluence was on offer to a growing proportion of the working population with class tensions mitigated as a consequence; capitalist power had been circumscribed by the extension of public ownership and the increasing strength of trade unions operating in a tight labour market; and a welfare state, funded from sustained economic growth, guaranteed a basic level of subsistence and expanding social services. Of course, as Crosland was well aware, there was still much to be done to create that just and equitable society to which social democrats aspired. Limits might have been reached to the redistribution of earned income but the redistribution of inherited wealth and gains from stock-market speculation were still priorities. Educational provision might have been extended but the educational system still reinforced class divisions. And, more generally, Britain remained a class-ridden, philistine, 'restrictive and puritanical' society to which the principles of equality, fraternity and above all liberty still had a profound prescriptive relevance. ${ }^{1}$ Nevertheless, by the mid-1950s a redistributive fiscal policy, the welfare state, the extension of public ownership to create a mixed economy, and Keynesian macroeconomic management 
seemed to have laid a solid and stable basis for future social democratic advance.

The economic circumstances of the 1950s and early 1960s provided good grounds for such an optimistic perspective. Growth may not have matched that of Britain's European competitors but it was at historically high levels and, for the most part, sustained. Living standards had improved to a point where socialist commentators agonised over the political and ideological challenges presented by an affluent society and, in particular, an affluent working class (see Black 2003). Full or near-full employment did prevail, the intermittent difficulties surrounding the balance of payments were periodically circumvented by a touch on the fiscal or monetary rudder, and the welfare state was increasingly well resourced. Bliss was it that dawn to be alive unless, of course, you were a member of the radical left.

In 1975 the annualised rate of inflation hit 25 per cent. At the same time unemployment continued to rise rapidly after having breached the politically sensitive one million mark earlier in the decade. Sterling entered yet another period of post-war crisis and in order to steady the ship the Labour government had recourse in 1975/6 to the financial lifeboat of the IMF (see Burk and Cairncross 1991; Hickson 2005). But this rescue came at a price for in theory, if not always in practice, pragmatically, if not always with intellectual conviction, the government felt obliged to embrace some of the nostra of monetarism and exert a measure of control over public expenditure in general and its public sector borrowing requirement (PSBR) in particular. In this context Callaghan's famous speech on the impossibility of spending one's way out of a depression was simply one outward sign of a new internalised fiscal rectitude. And it was somehow both poignant and historically appropriate therefore that in the same year as this speech, the IMF loan and the embrace of public expenditure cash limits, Crosland died. For his social democracy had been predicated upon an economic dispensation whose foundations seemed to have been fundamentally damaged. The Keynesian trade-off between unemployment and inflation seemed vitiated by stagflation, the continued growth of social welfare expenditure in the context of a faltering economy was clearly jeopardised and, in the light of all this, the existing public-private balance of the mixed economy was being challenged from both the left and the right.

Yet one ideologue's misfortune is another's opportunity, and by the mid1970 s a radical, social democratic alternative was on offer that consciously sought to address the deficiencies of Keynesian social democracy and effect a socialist resolution of the contemporary crisis. The theoretical foundations of this were to be found, primarily, in the political economy of Michael Barratt Brown (From Labourism to Socialism, 1972), Stuart Holland (The Socialist Challenge, 1975), the work of the Institute for Workers' Control 
and that of the Cambridge Economic Policy Group - Wynne Godley, Frances Cripps, et al. ${ }^{2}$ It was from such components that the political economy of a radical, left, Alternative Economic Strategy (AES) was constructed.

For the AES left, Keynesian social democracy had failed to maintain a high and stable, non-inflationary level of employment and sustained growth free from balance of payments crises. Nor had it delivered growth rates comparable to those enjoyed by Britain's major competitors. These failures were in large measure a product of the growing economic power of major, multinational corporations, that could either ignore or circumvent the means and the measures by which governments sought to pursue their economic objectives. To this end, the AES proposed a fundamental alteration in the balance of power within the mixed economy in favour of a public sector which would be extended to include at least the top twentyfive major industrial corporations. Moreover, in view of the dismal fate of the 1965 National Plan, what was proposed was planning with teeth and to this end, in addition to a substantial extension of public ownership, the strategy insisted that those major industrial corporations remaining in private hands should be brought into a national planning process with the state deploying a range of incentives and sanctions to ensure that they adhered to the objectives that emerged from it. The trade union movement was also to be integral to this process; integral both at a national and, it was envisaged, at an enterprise level as well. Further, to address the balance of payments difficulties and the haemorrhage of foreign reserves traditionally precipitated by the pursuit of expansionary, employment-creating policies, and which could certainly be anticipated with the implementation of a radical economic strategy, a greater or lesser level of protectionism was proposed; something which it was believed would probably necessitate Britain's exit from the EEC.

This strategy would lay the foundations for a marked improvement in economic performance and all that could follow from that in terms of increased social expenditure, but it would also, in particular through the democratisation of the planning process and enterprise decision-making, help to effect that 'decisive and irreversible shift of economic power in favour of working people and their families' that Keynesian social democracy had failed to secure (Labour Party 1973: 7).

The political economy of the AES left received considerable exposure in the 1970s and early 1980s. The proselytising efforts of the Institute for Workers' Control ensured that the political economy of industrial democracy was widely and enthusiastically disseminated (Thompson 2006: 200-3). The ideas of Stuart Holland and Michael Barratt Brown on the mesoeconomy of multinational corporations and its implications for socialism found their way into a number of Labour Party publications (see 
especially Labour Party 1973) and eventually into its manifestoes - most notably A New Hope for Britain (1983). And, within the Labour Party, there were those such as Tony Benn who were prepared to support and advance this strategy at Cabinet level.

The AES offered a different vision of capitalism from that of Keynesian social democracy and, in consequence, a different view of what needed to be done to ensure that the forward march of Labour was resumed. It was a view more in keeping with less propitious and more combative times; one more obviously tailored to the imperatives of crisis: both the national economic crisis and the ideological one that confronted the party. It is unsurprising therefore that it helped to set the parameters of its economic debates for a decade, from the early 1970s to the electoral debacle of 1983. In this respect it also reflected, and may indeed have played a part in effecting, a shift in the balance of power to the left within the party. Either way it was on an AES manifesto that the 1983 election was fought and comprehensively lost.

Yet within the AES, and for that matter within the AES-supporting left, there were critical tensions; in particular between the decentralisation of power implicit in the emphasis on the democratisation of enterprise decision-making and the centralisation of authority inherent in institutions such as the National Enterprise Board within the proposed planning apparatus. In this regard some aspects of the strategy were redolent of a socialist corporatism, with planning goals emerging from the interaction of trade union, political and enterprise elites, while others were couched in the neo-syndicalist patois of workers' control and the erosion of management prerogatives. This tension within the ranks of the AES left manifested itself in a number of ways but, in particular, in the different degrees of autonomy which it was envisaged enterprises would possess in the context of the strategy. So while those who stressed its decentralist and democratising tenor saw it as opening up opportunities for the kind of worker-formulated plans that had emerged from enterprises such as Lucas and Vickers (e.g. Beynon and Wainwright 1979; Cooley and Wainwright 1981), others quite clearly saw it as the basis for a national economic strategy, involving central economic planning, coordination and control, including control of foreign trade and capital movements.

Given such tensions it was, as one contemporary commentator put it, best 'to treat the AES not as a programme but as a field of debate' (Sharples 1981:25). And it certainly had a protean quality as regards the policy prescriptions that could be derived from it. As Sam Aaronovitch (1981: 6-7) wrote at the time, it was variously conceived

as a cure for economic decline, as a socialist programme, as the start of a struggle for socialism, as a programme that is democratic and radical without being socialist, as a mobiliser of broad support for the socialist idea, as a way 
of tipping the resolution of the economic crisis in favour of the working class and against capital, as a way of establishing enclaves of socialist production and working class power in a socialist society, or as a way of generating a revolutionary socialist mass movement

And, as Aaronovitch's remarks imply, it was multifaceted not simply in terms of its programme and strategy but in terms of the aspirations which were attached to these; aspirations that ranged from the decidedly reformist to the avowedly revolutionary; from those that were realisable within the framework of existing political institutions and processes, to those that could only be secured by means of the reality or threat of extra-parliamentary agitation and struggle. At best, therefore, it made for an unstable political alliance always likely to disintegrate should it be faced with the reality of political power or political defeat. The former never proved a problem and the latter duly precipitated such disintegration in the aftermath of the 1983 debacle.

Yet the crisis engulfing social democracy was not simply a function of unpropitious economic circumstances, the divisions within its political constituency or the redundancy, tensions and inconsistencies in its available political economies. For what it also confronted, from the $1960 \mathrm{~s}$ onwards, was a fundamental, multifaceted, well-orchestrated and wellfinanced ideological challenge to social democracy and, more generally, the whole post-war Keynesian social democratic consensus. Of course such a challenge had existed in the 1950s. From the right, there was the free-market political economy that derived inspiration from Hayek's Road to Serfdom (1944) and which was articulated in the work of writers such as John Jewkes and, from within the political community, Enoch Powell, Angus Maude and Geoffrey Rippon. But this radical right had a limited political impact and did little to dull the prevailing optimism of Crosland and others with respect to the future of social democracy. From the left, there were those such as Crossman, Bevan, Strachey, Cole and the Keep Left Group who saw a socialist project only partially completed, and who looked to a substantial extension of public ownership and planning in order to diminish capitalist power, enhance economic performance, redress the perceived imbalance between private affluence and public squalor and, most fundamentally, to effect a socialist transformation of economy and society. Yet, in truth, whether from left or right, these were clouds no bigger than a man's hand that cast a negligible shadow on the kind of optimism to be found in The Future of Socialism.

But by the 1960 s the critical fire coming from the right was intensifying. The work of Milton Friedman and others within the Chicago School called into question the capacity of the state to deliver on the commitment in the 1944 White Paper on employment policy to maintain a high and stable 
level of employment (Employment Policy 1944: 3). Thus, it was argued that, with a greater or lesser time lag, employment-inducing government expenditure would result not in lower unemployment but a higher general level of prices. Nor was there, as the Phillips curve had suggested, any tradeoff between employment and inflation (Phillips 1958); a view for which the experience of the late 1960s and 1970s appeared to provide empirical verification. Unemployment could not be decisively pushed below its 'natural' rate simply by macroeconomic expansion but only by eliminating rigidities in the labour market so that it functioned more efficiently. Keynesian demand management was, therefore, at best superfluous and, at worst, destabilising. Of course monetarism did not go unchallenged but from its spiritual home in Chicago it began to make important converts in Britain within the academic, journalistic and financial and political communities (see Cockett 1994; Denham 1996).

If the Chicago School challenged the efficacy of Keynesian demand management, those aspects of the economics of the Austrian School which had their roots in the work of Friedrich Hayek and Ludwig von Mises trumpeted the virtues of untrammelled markets, calling into question the possibility of rational state-initiated and/or directed collective action and intimating that it was only as a consequence of the process of learning and discovery implicit in the market-mediated maximising activity of individuals that the most efficient and socially beneficial allocation of resources was likely to arise.

Further, and central to the ideological challenge of the right, there was the public choice theory of the Virginia School, most notably the ideas of James Buchanan and Gordon Tullock, who took the methodological individualism of Austrian economics and applied it to the sphere of public decision-making. In their scheme of things, the actions of politicians and public bureaucrats, not just those active in the economic sphere, were explained by reference to the pursuit of utility maximisation. Power, prestige and career advancement became the maximands of public officials, with the maximisation of the size of public bureaus the means by which this was to be achieved. In the case of politicians, the primary objective was the maximisation of political power, which involved the building of political alliances to maximise votes, both within representative institutions and in terms of the electoral process. Both public officials and politicians were seen as pursuing their objectives through symbiotic relationships with producers and pressure groups: the latter seeking the bureaucratic and legislative support necessary to further their interests, while at the same time emphasising the imperative need for those public bureaucracies through which it could be provided (see Buchanan and Tullock 1962; Tullock 1965).

While, therefore, Keynesian social democracy was predicated upon a 
neo-Fabian conception of a public bureaucracy which was characterised by its dispassionate rationality, its expertise, its knowledge base, its competence, its independence, its industry, its integrity, its discharge of business according to calculable rules and, above all, by its inclination to perceive its work as a vocation and to labour primarily for the public good, public choice theory portrayed that bureaucracy as pursuing self-interested objectives that made for an inexorable expansion unwarranted in terms of the social utility which it yielded. ${ }^{3}$ In this respect, public choice theory furnished not only a critique of the imperatives driving public decision-making but also an explanation of what was coming to be seen as an inflationary growth of public expenditure which was inflicting significant damage on the wealth-generating private sector (see Buchanan and Wagner 1977). And, of course, the Keynesian idea of 'deficit spending and inflationary finance [also] tended to undermine whatever resistance there was to the expansion in the size of public budgets' (Buchanan and Wagner 1977: 69).

As regards this onslaught upon the central tenets of Keynesian social democracy, two other components of what came to be termed the New Right critique are worth noting. First, there was the idea that as a consequence of the inexorable rise of public expenditure, driven either by bureaucratic ambition or by a predilection for employment-inducing deficit financing, the private sector had been and was being 'crowded out' of the capital markets; something which explained Britain's poor, post-war growth performance and her relative economic decline. Such a skewed resource allocation made for 'too few producers'; or, as two of the most prominent proponents of this view - Bacon and Eltis - saw it, too few producing a marketable product (Bacon and Eltis 1976). This in turn was something which exacerbated balance of payments problems and inflationary pressures.

Second, and in line with this, there was the problem of 'overload' (King 1975). Thus because the state was assuming an increasing range of responsibilities, it was rapidly losing its capacity to do what it did do effectively. Overload also raised issues of individual choice, freedom, initiative and independence, while the costs entailed by a burgeoning range of activities made for a growing fiscal burden; one that militated against enterprise and competitiveness and acted as an incentive to corporate disinvestment and exit.

The coherence of the New Right assault upon Keynesian social democracy has been much debated. What cannot be disputed, though, is both the breadth of the front upon which it was mounted and the scale and intensity of its popularisation. As to the latter, think tanks such as the Institute of Economic Affairs, the Centre for Policy Studies and the Adam Smith Institute played an important role both in disseminating these ideas 
within the Conservative Party and to a wider political constituency. And they can, certainly, be frequently found in the speeches and writing of key figures within that Party by the mid-to-late 1970s (see, in particular, Joseph 1976). More generally by that time they were beginning to dominate the ideological debate that arose in Britain in the last quarter of the twentieth century.

Of course, by the mid-1980s, elements of the New Right political economy were theoretically and prescriptively bankrupt and therefore ceased to present a significant challenge to social democracy, but the philosophy of marketisation retained its hegemony throughout the 1980s and into the 1990s and, as a result, social democracy remained on the back foot. In terms of its popular resonance, the philosophy was a potent one. It articulated the virtues of individual freedom, choice and consumer sovereignty: the freedom to purchase one's council house, to choose between utility suppliers and, in the aftermath of successive privatisations, to participate in the equity market. It was a philosophy that conceptualised the users of public services as clients or customers not as supplicants. It spoke the language of efficiency and value for money in relation to public services and of opening them up to quasi-market imperatives. It looked to the dismantling of concentrations of administrative power: the streamlining of bureaucracies, with a consequent reduction in the burden on taxpayers, leaving them with more money and therefore more choice in the marketplace. It underpinned the idea of privatisation and deregulation which furnished the multiple providers of 'public' and private goods and services that made choice a reality. ${ }^{4}$ Whether the reality matched the hype was of little consequence. Such ideas and ideals both shaped, and resonated with, the popular mood, imbuing it with notions that the opportunity to secure what was desired in the cheapest market was an unqualified good and that the acquisitive instinct was something to be applauded not derided or condemned.

By way of response to the challenges such a political economy posed and to the electoral disaster it precipitated, there was an attempt, in the 1980s, to reconstitute Keynesian social democracy on a sounder basis; one that took account both of the ideological ascendancy of the New Right and the cumulative consequences of Conservative economic policies. As to the second of these, there was a belief, particularly in the earlier part of the decade, that Keynesianism had once again acquired a compelling relevance as an economic strategy in the light of what Thatcherism had produced. Mass unemployment and a crumbling industrial base were once more, as in the 1930s, salient characteristics of the British economy and, as Giles Radice saw it, 'a Labour government' would be 'entitled to have confidence in sensible, moderately applied and well-balanced Keynesian policies' (Radice 1989: 
115). Once again public expenditure could and should be 'an important element in getting the economy moving', and Austen Mitchell was even prepared to defend the Barber-Heath dash for growth of the early 1970s as an experiment that had fallen victim to adventitious circumstances rather than one which was theoretically flawed (Gould et al. 1981: 202; Mitchell 1983 and 1989). Moreover, as the 1980s progressed, monetarist theory came to look increasingly suspect as a guide to macroeconomic policy and was progressively abandoned in consequence.

By the late 1980s privatisation had also altered the landscape confronting social democracy and therefore parameters of the debate surrounding public ownership. Given the costs involved, it became difficult to aspire to any return to the status quo ante and so discussion came to be focused on whether, at the margins, it was possible to establish a more balanced mixed economy than that which Thatcherism was creating. In this context there was a tendency to favour the micro expedients suggested by Crosland, Jenkins and others in the 1950s: social ownership taking the form of equity participation and the public ownership, or creation, of individual enterprises; the idea being to compete with, stimulate or complement the private sector. What was wanted was a 'healthy pluralism' of forms of ownership, with the state eschewing a dominant role: its general objective, in the words of Austen Mitchell, was 'to manage and work with capital to the benefit of all, not to expropriate it' (Mitchell 1989: 114-15). In the work of Mitchell, Gould, Hattersley, Radice and others there was, therefore, a Keynesian social democratic vision of a mixed, pluralistic, competitive market economy, with an emphasis on social control rather than ownership, which was markedly similar to that of the revisionists of the 1950s (for further discussion, see Thompson 2006: 246-7). However, while this represented an attempt to recognise and accommodate some of the harsh realities that emerged with the hegemony of Thatcherism, for many within the party in the 1990s even these writers failed to understand how far the tide of public ownership had and would continue to ebb; a view of things that was to underpin the determination on the part of the leadership to abandon clause IV, which it duly did in 1994. In effect, therefore, the new realism of these writers led inexorably to an abandonment of any aspirations for extending public ownership; an abandonment, therefore, of the vision of a mixed economy which had previously been one of the central pillars of Keynesian social democracy.

Moreover, while it might be argued that the revisionist liberal socialism of the 1980s was more relevant to a new age of mass unemployment and a regressive redistribution of income and wealth, there was little to distinguish it from the Keynesian social democracy which had failed to negotiate the crisis of the 1970s. The continued existence of the inflation, 
balance of payments and international confidence constraints of those years was acknowledged, but the expedients suggested to circumvent them were remarkably similar to those already tainted with failure. So balance of payments pressures were to be mitigated by devaluation and/or a flexible exchange rate, together with selective import controls (Gould et al. 1981: 204-6; Mitchell 1981: 49). As Mitchell saw it, 'the economy must be insulated in order to expand and in this respect the exchange rate is the key to both competitiveness and insulation' (Mitchell 1989: 52). There was, admittedly, a recognition that devaluation had been tried before as a means of creating the economic space required to pursue an expansionary policy but, it was argued, only in extremis and never as part of a coherent strategy.

As for the danger of a capital flight precipitated by such expansionary policies and redistributive social democratic economic strategy, this was to be addressed by the restoration of exchange controls and inducements to pension funds, insurance companies and other institutions to repatriate a proportion of their overseas investments. In any case, sustained growth would attract inward investment; though this presupposed the presence of what the strategy proposed to deliver (Hattersley 1985a and 1985b).

Of course it was recognised by many that Britain's membership of the EEC clearly constrained the capacity of any government to put in place the kind and level of economic insulation needed to permit a crisisfree expansionary strategy. And, as Hattersley himself opined, "no one believes that British withdrawal from the EEC will be a major feature of the next general election campaign' (Hattersley 1983: 5). Indeed, by the late 1980s, there were few serious politicians who did not accept Britain's membership as a fait accompli.

In addition, a number of other developments had by that date rendered defunct or inapplicable the insulatory expedients mooted by these liberal socialist revisionists. With respect to exchange controls, for example, in 1988, as part of the moves towards the Single European Market of 1992, all European countries agreed to remove them completely within two to four years and, of course, Britain had already removed its controls in 1979. In addition, and globally, 'OECD countries agreed in May 1989 to extend the OECD Code of Liberalization of Capital Movements to cover all international capital movements' (Helleiner 1994: 166). In consequence, exchange trading and international capital flows grew exponentially in the late 1980 s and 1990s. The daily value of the former, which had stood at $\$ 150$ billion in 1985 , had risen by the late 1990 s to $\$ 1.2$ trillion; international bank lending grew from $\$ 265$ billion to $\$ 4.2$ trillion in the twenty years after 1975 and, in the same period, the value of foreign direct investment rose from $\$ 21.5$ billion to $\$ 400$ billion (Strange 1986; Helleiner 1994). 
The Big Bang in October 1986, by opening up the London stock exchange to foreign securities firms, also made for a liberalisation of financial markets that militated against the idea of Keynesian demand management in one country. Finally, by the late 1980s, the world's top 200 transnational corporations (TNCs) had an annual turnover equivalent to 30 per cent of the gross world product, while the late 1990s saw the emergence of the first corporations with trillion-dollar turnovers (Costello et al. 1990: 39). And this expansion in the power and resources of TNCs seemed increasingly to vindicate the AES critique of any social democratic strategy that failed to recognise and obviate their capacity to frustrate or circumvent macroeconomic management at a national level.

Many might have demurred at John Gray's view that it is no exaggeration to say that the global freedom of capital effectively demolishes the economic foundation of social democracy' (Gray 1996: 26). But few would have disagreed that in the light of these developments the autonomy necessary to pursue a Keynesian social democratic strategy had been severely circumscribed. Leaving aside the haemorrhage of imports and capital that a radical social democratic strategy might precipitate, a redistributive policy that sought to effect an irreversible shift in economic and political power in favour of working people and their families, because of its fiscal implications, would almost certainly provoke the exit of investors intent on maximising their returns under fiscally more benign regimens (see e.g. Gill 1992: 172). John Smith, in a speech to the TUC Congress in September 1993, might still feel able to state that 'the goal of full employment remains at the heart of Labour's strategy' but in retrospect this seems to have been little more than the death throes of an aspiration the realisation of which was no longer nationally realisable by Keynesian means (Anderson and Mann 1997: 88-90).

As to the problem of inflation, the Keynesian social democrats of the 1980s believed that consensus over the rate of wage and salary increases could be achieved and would dampen the expectation and thence the reality of such pressures. The notion of a statutory incomes policy was rejected but great faith was placed in non-statutory notions such as 'income planning', 'a consensus on income and wage increases' and a 'social compact' (Hattersley 1987: 241; Radice 1989: 117; Mitchell 1983: 102). Of course, it could be argued that with a profoundly weakened trade union movement such ideas were more obviously within the realm of practical policy than they had previously been, but this aspect of a rejuvenated Keynesian social democracy had about it the feel of a political economy that had had, if not its day in the sun, then at least its winter of discontent in the gloom of 1978/9. In particular, this continued willingness to truck and barter with the trade union movement was, and would remain, an electoral asset for 
the Conservatives; one which they ruthlessly exploited, with few speeches on the subject failing to evoke images of unburied corpses and rubbishstrewn streets.

Taking this reformulation of a Keynesian social democratic political economy as a whole, therefore, it would seem that little, or at least too little, had changed; an impression strengthened by Labour's electoral fortunes in the 1980s and early 1990s, which showed little sign of altering even after the principles and proposals of this reconfigured social democracy had begun to infuse Labour's literature. But more than this, in terms of winning hearts and minds, there was, as we have seen, the major difficulty that Keynesianism in one country appeared to have been rendered otiose by developments at a European and a global level. Despite the best efforts of Mitchell, Hattersley, Radice, Gould and others, the political economy, and political performance, of British social democracy therefore remained in crisis throughout the 1980s and on into the next decade: a crisis of conviction as to whether its policy prescriptions were relevant, viable or coherent.

Yet there remained the possibility of multilateral or multinational social democracy. Thus as Michael Barrett Brown had come to see it, while in the past

the nation state and the power of national association, and particularly of organised labour, offered the only realisable countervailing power. Now ... such national resources are no longer adequate. In the face of the concentrated power of the organisations of capital in the giant European corporations, nothing less will do but that European-wide structures - both political and economic - should be built and maintained and European-wide social policies should be conceived and fought for. (Brown 1991: 1)

In particular, European-wide or global structures were seen as permitting a multilateral, Keynesian-style pursuit of full employment that would avoid balance of payments and exchange rate pressures, while making available the financial resources necessary to counter the effects of capital flight, or even hinder its occurrence. So, for some, Keynesian social democrats should now "concentrate their hopes on the high road of macroeconomic coordination between the United States, Japan and Western Europe or on the low road of economic policy integration in the European Community' (Scharpf 1991: 249).

Such a strategy was given some credibility and political impetus by the European Commission President, Jacques Delors, who declared that the EU would be 'the theatre in which social democracy accomplishes its missions' and who, in 1992, argued for an ambitious European programme of infrastructural investment both to enhance European competitiveness and to 
reduce the level of European unemployment (Delors 1989: 31); a strategy which was articulated at some length in publications such as Coates and Barratt Brown's A European Recovery Programme (1993) and Holland and Coates's Full Employment for Europe (1995; see also Holland 1983). These ideas also found their way into Labour Party literature of the early 1990s in pamphlets such as Labour's Economic Approach, 1993. Further, many of these writers looked to Europe to advance the redistributive ambitions of the welfare state on a supranational basis; ambitions which, in a national context, had been eroded by the public expenditure 'crises' of the 1970s and 1980s and the ideological assault of the New Right. And it was indeed the case that, in the early 1990s, the socialists formed the largest group in the European Parliament and interpreted the concept of 'Social Europe' in ways which highlighted its redistributive, egalitarian and socially cohesive potential.

A supranational welfare state was therefore seen by some in Britain as being able to advance the social welfare ambitions of social democrats while at the same time furnishing a basis for greater European social cohesion and solidarity in the face of trans-national capital. More specifically, in place of the existing competitive pursuit of TNC-related inward investment which, among other things, could threaten labour rights, the EU, by means of monitoring and enforcement, could ensure an acceptable standard of corporate practice, thereby preventing complicity in so-called "social dumping' by investment-hungry nation states. In this regard, many on the left were to stress the potential of the Social Charter and then the Social Chapter of the Maastricht Treaty (see e.g. Hughes 1991: 4).

But there were, and are, fundamental problems with a political economy of multinational social democracy. First, the kind of macroeconomic leverage that could be exerted within and by the EU to achieve broad strategic objectives was severely constrained by the funds available for deployment at a European level. As late as 1997, EU expenditure accounted for only 3 per cent of the total public expenditure of its member states, while throughout the 1990s the EU budget remained less than 1 per cent of their GDP (Delors 1993: 46; MacKay 1995: 170). Moreover, commentators identified formidable coordination problems as well as difficulties surrounding the abandonment of, or reduction in, control over key economic policy instruments conventionally seen as integral to national sovereignty. In fact, the Delors plan ran into the sands after 1993, spelling an end to any possibility of a Euro-Keynesian expansionary strategy. And, certainly, there was not even a whiff of Euro-Keynesianism in New Labour: New Life for Britain, the Labour Party's draft manifesto published in 1996. Greater European labour market flexibility not demand-led expansion was what New Labour now saw as creating jobs. 
Second, this deficiency of resources, and consequent absence of significant leverage, was indicative of a more general obstacle in the way of a radical social expenditure strategy. For while member states were prepared to concede autonomy, sometimes considerable autonomy, in matters relating to monetary and exchange rate policy, this did not extend to those areas of policy which necessitated significant public expenditure, for this would entail the loss of control over some considerable part of the nation's finances. For that reason alone, the formulation of a comprehensive European social welfare policy was unlikely to occur.

Third, the social dimension of the EU was always likely to be an ideological battleground; something militating strongly against concerted action. And, in any case, even assuming a sustained ascendancy of the social democratic left, there was an absence of democratically accountable institutions, parties and individuals, subject to a popular mandate, by means of which a popularly driven European economic and social strategy might be pursued (on this point, see Chapter 9 in this book). Further, even assuming away these difficulties, there was still the problem that any harmonisation upwards of social welfare provision and workers' rights was seen as likely to create major competitive difficulties for those nations at a lower level of economic development.

Finally, with respect to monetary management, some social democratic writers fantasised about a European Central Bank, operating under guidelines established by the European Parliament and pursuing an employmentgenerating expansionary policy. But a Bundesbank-style independence was the modus operandi of choice at Maastricht, with little scope envisaged for democratic control, even if the requisite European institutions had been available. And, as for the Labour Party, it was of course to embrace and to realise the principle of central bank independence at a national level shortly after coming to power in 1997.

The actual experience of the 1990s confirmed the magnitude of these obstacles in the way of social democratic progress at a European level. So while "the programme to create a single market has surged ahead on the basis of concrete EC law . . . the proposals to build a Social Europe have dragged behind and encountered the utmost difficulty in being translated into European action' (Wise and Gibb 1995: 257). As one commentator put it in 1996, 'today, the battle on the political economy of European Union is over ... Thatcher won and Delors lost, and ... this is very likely to be irreversible' (Streeck 1996: 302).

The contemporary crisis surrounding the political economy of social democracy is therefore profound. In the 1950s and early 1960s some such as Crossman, Bevan, the Socialist Union, and the New Left might talk the language of crisis and wonder how to take forward the Fabian project of 
the Attlee years, but there was then, in Keynesian social democracy, a dominant paradigm that had established the parameters of political debate and policy-making. By the 1990s, however, there was no such political economy. Indeed, there was compelling evidence that the alternative political economies available to the post-war left had been tried and found wanting, or simply inapplicable, to the economic circumstances of fin de siècle capitalism. Either, like the AES, they sought to accommodate contemporary developments in a manner that was neither economically feasible nor electorally viable or, as with the reconfigured Keynesian social democracy of the 1980s, they presupposed a national economic autonomy that failed to appreciate the magnitude of qualitative and quantitative changes in the global economy. As to the multilateral socialism which did show that appreciation, this was predicated upon such a fundamental change in institutions and mindsets as to render it otiose from the outset; something which even its devotees rapidly came to understand.

Global economic developments aside, there was also the major alteration in the political landscape that had occurred in the 1980s and which influenced the terrain upon which elections might be fought and won. The privatisation of national assets; the attack on, and erosion of, the notion of a public service ethos; the celebration of possessive individualism; the fostering of a culture of contentment; all left their imprint on popular consciousness, or strengthened already existing characteristics and trends in ways that constrained the kind of political economy which, consonant with its electoral ambitions, the Labour Party could embrace. Certainly, this is one likely reason why in the run-up to 1997 the radical, social democratic 'stakeholderism' of Hutton and Kay was first diluted and then jettisoned altogether (Thompson 2003).

In this context, British social democracy found itself between Scylla and Charybdis. If it failed to meet the challenge of the New Right on the terrain of freedom, choice, consumer sovereignty, property-owning democracy, and the marketisation of public provision, it was likely to lose electoral ground. In so far as it sought to accommodate these ideals it risked diluting some of its fundamental principles. The AES adopted the former stance which proved electorally disastrous. New Labour adopted the latter and thereby locked itself into a political economy which many social democrats regarded as neo-or, at best, post-Thatcherite. Electoral suicide or ideological death: these were the alternatives on offer.

Of course for some the evolving political economy of the third way has provided a modernised social democracy; or, at least, the basis for one. It can be argued too that it has opened up actual and potential avenues of social democratic advance, even if it does not provide the overarching theoretical framework and meta-narrative furnished by Fabianism or Keynesian social 
democracy. This political economy may not entirely resolve the ideological crisis of contemporary social democracy but it may be seen as providing the lineaments of such a resolution. It is beyond the remit of this contribution to discuss such contentions, which are examined in detail elsewhere in this book (see, for example, Chapters 4, 6 and 7). It is clear, though, that many of the following chapters, like the conferences which inspired them, are predicated on a faith that there still exists the ideological space in which to rethink the social democratic project. Faced with this belief it would, at this early stage of the book, be churlish to demur.

\section{Notes}

1 For a discussion of Crosland's social democratic ideas and their relevance to contemporary politics that contrasts with that offered in this chapter, see Chapter 11 in this book.

2 On this aspect of the Alternative Economic Strategy, see Thompson 2006: 203-4. For a fuller account of the political economy of the Alternative Economic Strategy than can be provided here, see Thompson 2002: 29-69 and, for a detailed account of the politics surrounding it, Wickham-Jones 1996.

3 For a more extended discussion of the Virginia School critique of public bureaucracy and its implications for the idea of a public service ethos, see Thompson 2008.

4 For further discussion of how the philosophy of marketisation impacted on thinking about public service provision in the 1980s and 1990s, see Chapter 8 in this book and Thompson 2007.

\section{References}

Aaronovitch, S. (1981) The Road from Thatcherism: the Alternative Economic Strategy (London: Lawrence \& Wishart).

Anderson, P. and Mann, N. (1997) Safety First: the Making of New Labour (London: Granta).

Bacon, R. and Eltis, W. (1976) Britain's Economic Problem: Too Few Producers (London: Macmillan).

Barratt Brown, M. (1972) From Labourism to Socialism (Nottingham: Bertrand Russell Peace Foundation).

Barratt Brown, M. (1991) European Union: Fortress or Democracy? (Nottingham: Spokesman).

Beynon, H. and Wainwright, H. (1979) The Workers' Report on Vickers (London: Pluto).

Black, L. (2003) The Political Culture of the Left in Affluent Britain, 1951-64 (Basingstoke: Palgrave).

Buchanan, J. and Tullock, G. (1962) The Calculus of Consent: Logical Foundations of Constitutional Democracy (Ann Arbor: University of Michigan Press). 
Buchanan, J. and Wagner, R. (1977) Democracy in Deficit (London: Academic Press). Burk, K. and Cairncross, A. (1991) Goodbye Great Britain: the 1976 IMF Crisis (New Haven: Yale University Press).

Coates, K. and Barratt Brown, M. (eds) (1993) A European Recovery Programme (Nottingham: Spokesman).

Cockett, R. (1994) Thinking the Unthinkable: Think-Tanks and the Economic CounterRevolution, 1931-83 (London: Harper Collins).

Cooley, M. and Wainwright, H. (1981) 'The Lucas plan: its lessons for Labour', New Socialist, 2.

Costello, N., Michie, J. and Milne, S. (1990) Beyond the Casino Economy (London: Verso).

Crosland, C. A. R. (1956) The Future of Socialism (London: Cape).

Delors, J. (1989) 'A new frontier for social democracy', in P. Dankert and A. Koopman (eds), Europe Without Frontiers: Socialists on the Future of the European Community (London: Cassell).

Delors, J. (1993) 'The scope and limits of Community action', in K. Coates and M. Barrett Brown (eds), A European Recovery Programme (Nottingham: Spokesman). Denham, A. (1996) Think-Tanks of the New Right (Aldershot: Dartmouth).

Employment Policy (1944) cmd 6527 (London: HMSO).

Gill, S. (1992) 'The emerging world order and European change: the political economy of the European Union', in L. Panitch and R. Miliband (eds), Socialist Register (London: Merlin).

Gould, B., Mills, J. and Stewart, S. (1981) Monetarism or Prosperity (London: Macmillan).

Gray, J. (1996) After Social Democracy (London: Demos).

Hattersley, R. (1983) Labour's Choices, Fabian Tract No. 489 (London: Fabian Society).

Hattersley, R. (1985a) 'Exchange control', New Statesman, 22 February.

Hattersley, R. (1985b) 'An alternative to the alternative: Labour's economic strategy', Marxism Today, October.

Hattersley, R. (1987) Choose Freedom: the Future for Democratic Socialism (Harmondsworth: Penguin).

Hayek, F. A. (1944) The Road to Serfdom (London: Routledge).

Helleiner, E. (1994) States and the Emergence of Global Finance: from Bretton Woods to the 1990s (Ithaca: Cornell University Press).

Hickson, K. (2005) The IMF Crisis of 1976 and British Politics (London: I. B. Tauris).

Holland, S. (1975) The Socialist Challenge (London: Quartet).

Holland, S. (1983) Out of Crisis: a Programme for European Recovery (Nottingham: Spokesman).

Holland, S. and Coates, K. (1995) Full Employment for Europe (Nottingham: Spokesman).

Hughes, J. (1991) The Social Chapter and the Single European Market: Towards a Socially Responsible Community (Nottingham: Spokesman).

Joseph, K. (1976) Stranded on the Middle Ground? Reflections on Circumstances and Policies (London: Conservative Political Centre). 
King, A. (1975) 'Overload: problems of governing in the 1970s', Political Studies, 23. Labour Party (1973) Labour's Progamme, 1973 (London: Labour Party).

Labour Party (1983) A New Hope for Britain (London: Labour Party).

Labour Party (1993) Labour's Economic Approach (London: Labour Party).

MacKay, R. (1995) 'European integration and public finance: the political economy of regional support', in S. Hardy (ed.), An Enlarged Europe (London: Kingsley).

Mitchell, A. (1981) 'Political aspects of unemployment: the alternative policy', in B. Crick (ed.), Unemployment (London: Methuen).

Mitchell, A. (1983) The Case for Labour (London: Longman).

Mitchell, A. (1989) Competitive Socialism (London: Unwin).

Phillips, A. W. (1958) 'The relation between unemployment and the rate of change of money wages in the United Kingdom, 1851-1957', Economica, 25.

Radice, G. (1989) Labour's Path to Power: the New Revisionism (London: Macmillan).

Scharpf, F. (1991) Crisis and Choice in European Social Democracy (London: Sage).

Sharples, A. (1981) 'The politics of the alternative economic strategy', Marxism Today, April.

Strange, S. (1986) Casino Capitalism (Oxford: Blackwell).

Streeck, W. (1996) 'Public power beyond the nation state: the case of the European Community', in R. Boyer and D. Drache (eds), States Against Markets: the Limits of Globalization (London: Routledge).

Thompson, N. (2002) Left in the Wilderness: the Political Economy of Democratic Socialism Since 1979 (Chesham: Acumen).

Thompson, N. (2003) 'That stakeholder moment: New Labour's embrace of the Anglo-American model', Renewal, 11.

Thompson, N. (2006) Political Economy and the Labour Party: the Economics of Democratic Socialism, 2nd edn. (London: Routledge).

Thompson, N. (2007) 'From Hayek to New Labour: the changing ideology of public sector provision', in P. Dibben, P. James, I. Roper and G. Woods (eds), Modernising Work in Public Services: Redefining Roles and Relationships in Britain's Changing Workplace (Basingstoke: Palgrave).

Thompson, N. (2008) 'Hollowing out the state: public choice theory and the critique of Keynesian social democracy', in Contemporary British History, 22.

Tullock, G. (1965) The Politics of Bureaucracy (Washington, DC: Public Affairs Press.

Wickham-Jones, M. (1996) Economic Strategy and the Labour Party: Politics and Policy-Making, 1970-83 (Basingstoke: Macmillan).

Wise, R. and Gibb, M. (1995) 'A social charter for a European social market', in M. Ugur (ed.), Policy Issues in the European Union (Dartford: Greenwich University Press). 


\section{Part II}

\section{Responses to the crisis: the Third Way and other revisions}





\title{
The political economy of French social democratic economic policy autonomy 1997-2002: credibility, dirigisme and globalisation
}

\author{
Ben Clift
}

\section{Introduction: the crisis of social democracy}

The U-turn of French Socialism in 1983 saw a retreat from egalitarian redistribution, full employment and social justice as the priorities of economic policy. A prolonged period of ideological and programmatic flux ensued. The manifest failure of a decade of Socialist Government to make any impression on the soaring unemployment figures was devastating. This, acting in tandem with widespread disdain for a sleaze-ridden Socialist elite, heralded the biggest defeat in the history of French Socialism in 1993. These developments were grist to the mill of the 'end' of social democracy thesis, which has been pronounced repeatedly, with varying degrees of conviction in recent decades (Dahrendorf 1990; Giddens 1994; Gray 1996, 1998). However, French social democracy was not dead. In fact, it rose under Lionel Jospin like a phoenix from the flames in 1997. This attests to the capacity for ideological innovation, and renovation, within social democracy. How could reports of the death of social democracy, pronounced so assertively by such eminent scholars, have been so mistaken? The answer lies in how social democracy is conceived, and some hidden assumptions within these commentaries.

There is a tendency to identify social democracy first with a particular set of institutional 'means' (such as corporatism) and second with the policy paradigms within which those means were couched (such as 'Keynesianism'). The fortunes of social democracy are then evaluated in terms of particular means through which the political aspirations of social democracy have been channelled. There is an elision within some of this analysis, which assumes that because the political claims of social democracy were advanced through a particular set of policies or institutions, therefore social democracy is ultimately reducible to those elements. It 'follows' that the continuing viability of these institutions 
or policy approaches is a necessary condition of the enduring viability of social democracy.

Yet this ahistorical conception misconstrues the relation between social democracy's programmatic goals and the means deployed in pursuit of social democratic ends. Fundamentally, it misunderstands the nature of social democracy and prematurely discounts its capacity for renewal (Clift 2003a). A changed international economic and domestic political context (the end of embedded liberalism) requires us to look at how social democratic goals are pursued today, and to trace the outline of a new political economy of social democracy. The ends - securing equality of outcome and opportunity, redistribution to the most needy in society, and facilitating the widest possible access to employment within society - can, in the broadest terms, be summarised as the attempt to reconcile social justice with economic efficiency. These ends have remained the same across time. The means, however, have evolved significantly. With this in mind, this chapter explores the successes and failures of the Jospin era (1997-2002), and interrogates its implications for the analysis of social democracy more broadly, and its compatibility (or otherwise) with globalisation, and deregulated financial markets.

This chapter charts how the credibility built after the 1983 U-turn through firstly competitive disinflation and subsequently the 'ordoliberal ${ }^{1}$ foundations of EMU generated policy space exploited by the Jospin Government. It then assesses enduring volontarisme in French Socialist economic and social policy-making, analysing the employment and redistribution oriented economic policies central to the 1997-2002 period. Finally, it explores successful attempts at institutional re-engineering of the EMU architecture, notably expanding scope for dirigiste fiscal policy, and rearticulating dirigiste policy approaches at the supranational level.

\section{Social democracy, credibility and globalisation}

As Eatwell argues, 'today the sheer scale of speculative flows can easily overwhelm any government's foreign exchange reserves . . . Credibility has become the keystone of policy-making in the nineties ... Governments which fail to pursue "sound" or "prudent" policies are forced to pay a premium on the interest costs of financing their programmes. Severe loss of credibility will lead to a financial crisis' (1995: 278). This can pose particular problems for social democratic governments, since their policy aspirations are more likely to fly in the face of such prudence, and the markets tend to be slower to trust them. Social democratic governments have found themselves constrained to pursue tight monetary policies in order to avoid incurring a 'risk premium' imposed on borrowing by investors suspicious of potentially inflationary macroeconomic stances. Thus capital mobility 
and financial deregulation have changed the cost-benefit analysis of social democratic macroeconomic strategies. Social democrats have become increasingly convinced of the merits of 'stability', or low and stable rates of inflation and fiscal discipline, as a means of securing credibility. Many adopt 'risk-averse, cautious macroeconomic policies seeking to secondguess the reactions of global financial markets and to secure their approval' (Held et al. 1999: 230).

Yet, while it is undoubtedly the case that the power balance has shifted in favour of private capital holders, such a disparate and diverse group of actors do not, in any uniform or predictable manner, 'impose' a policy agenda on states. Nor is it necessarily accurate to characterise all aspects of the new policy package as neo-liberal. Some of the changed parameters of economic policy-making relate to changed realities of the global economy. It is important to draw distinctions between different elements of economic policy packages, and recall that while certain aspects may be closely linked to neo-liberal policy agendas, others are perfectly compatible with social democratic ones. The credibility demanded by financial markets does have ideological dimensions, often rooted in a broadly neo-liberal view of economic activity, but it is also to an extent a reflection of changed economic realities. The size, scale and speed of global financial flows mean that governments have to pay close attention to their credibility rating with financial markets (Eatwell 1995; Balls 1998).

Such discussion often segues into talk of the exhaustion of the Keynesian political economic paradigm, and to the decisive renunciation of Keynesianism (and indeed a commitment to full employment). This is a familiar refrain of many authoritative works in comparative and international political economy. These are usually placed in the context of the breakdown of 'embedded liberalism'2 internationally, and of the rise of the New Right and monetarism ideologically. The supposed repudiation of Keynesianism is often 'explained' by a changing international political economic context within which Keynesian economic policies are deemed increasingly incompatible (Giddens 1998: 16-17). Gray's pessimistic account infers from the assumed centrality of neo-liberal orthodoxy to 'credibility', and the changing cost-benefit analysis of national economic policies, that 'global mobility of capital and production in a world of open economies have made the central policies of European social democracy unworkable' (Gray 1998: 88-9).

Yet the mooted incompatibility of economic strategies inspired by Keynesian thinking with the new international political economic context of global financial markets has been exaggerated (Clift and Tomlinson 2007). Particular Keynesian policies are sustainable in principle in a 'globalising' world. The role of public investment reserved for fiscal policy 
within Keynesianism is not 'ruled out' by the new global economy. Rather, globalisation requires new institutions and prerequisites in order to secure credibility with financial markets, thence to exploit the policy space available to pursue the politics of social democracy. Securing credibility through stability-centric macro policy stances is compatible with a wide range of different priorities in other areas of economic policy. Arguably, the French Socialists' political economy between 1997 and 2002 (and New Labour's since 1997), was able to reconcile both the securing of credibility with international financial market actors and substantial fiscal policy space within which to pursue domestic economic policies of a broadly Keynesian character. Within a framework of a commitment to macroeconomic stability, there remains room for manoeuvre over the degree of 'orthodoxy', as well as a whole range of other economic policy tools which may be exploited to prioritise 'social democratic' goals. A commitment to stability does not condemn a social democratic government to budgetary immobilisme, and even opens the door, despite the rejection of 'fine tuning', to a significant Keynesian influence on policy in pursuit of full employment.

\section{Jospin, the rebirth of French social democracy and dirigisme}

The remainder of this chapter explores the relationship between French social democracy and globalisation in the period 1997-2002, centring on the role of credibility within French socialist political economy. Securing credibility was one important means by which French socialists reconciled themselves to globalisation whilst retaining dirigiste policy space for egalitarian economic interventionism. Jospin's policy record, detailed below, offers evidence that the degree of room for governmental manoeuvre is not as heavily circumscribed as the neo-liberal rhetoric of globalisation suggests. The Jospin government's activism gives the lie to the hyper-global discourse on globalisation. This suggests more complex responses to the process of globalisation in practice than neo-liberal rhetorical deployments of globalisation.

To understand the political economy of French social democracy, it is important to appreciate the distinctive French state tradition of stateeconomy relations known as dirigisme. Dirigisme has been succinctly defined as 'a set of interventionist policies and directive policy-making processes' (Schmidt 1997: 229). A concept central to understanding dirigiste policy impulses throughout the twentieth century is volontarisme, a political term which refers to an activist, interventionist economic policy approach which places emphasis on the discretionary actions of policymakers. Jospin translates volontarisme as 'the active state' (1999).

Central to France's dirigiste interventionism after the Second World War was the state's role in providing funds for industrial investment (Zysman 
1983). The state's centrality to the system of 'institutionally allocated credit' (as opposed to 'asset-based credit') from private and public banks gave the French state extraordinary leverage to act as 'gatekeeper' in providing access to 'strategic', cheap capital. The degree of dependence of industrial and financial capital on the state was highly distinctive. State loans tended to be conditional upon meeting specific restructuring targets, incorporating subsidiaries into parent companies, or merging with other big firms. In addition to the 'economy of administered finance', a further characteristic of the French model was the 'inflationist social compromise' (Cohen 1995). The state's inability to control the inflationary growth of credit was compounded by 'the consensual refusal of the state, the trade unions, and the employers to control nominal changes in incomes and prices' (Cohen 1995: 26). As well as macroeconomic policies such as competitive devaluation and a broadly Keynesian set of fiscal and welfare state policies (Rosanvallon 1989), there was a panoply of instruments and institutions geared towards microeconomic interventionism in the French economy. The making of economic policy in France was a source of national pride for much of the post-war period, widely credited as the reason behind France's trente glorieuses (thirty glorious years) of post-war economic growth and widening prosperity and affluence.

Post-war French dirigisme was predicated on the international economic institutions of Bretton Woods, what Cox calls Pax Americana (1987: 7). As that system unravelled amidst the Nixon shock, oil crises, and advancing liberalisation and deregulation in the 1970s, France's dirigiste policy paradigm came under increasing strain. International financial liberalisation, for example, rendered the dirigiste 'credit rationing' approach to monetary policy increasingly unworkable (Cohen 1996: 351).

In the international political economic context of the 1990s and 2000s, which differs markedly from post-war 'embedded liberalism' (Ruggie 1982), dirigisme is articulated in a different, more circumspect, manner than was the case in the heyday of the French model (Zysman 1983). This presupposition in favour of dirigiste interventionism has come under increasing threat in the last twenty-five years from structural changes in global financial markets, from the European Union, and from the ideological ascendancy of neo-liberalism.

The process of European integration, which gathered momentum after the 1984 Fontainebleau Summit, was built upon decidedly non-dirigiste economic foundations. The 1986 Single European Act, and the neoliberal understanding of state-economy relations that underpinned it, had wide-ranging implications for French political economy. Drawing heavily on US anti-trust regulation, the new competition regulation framework saw state industrial subsidies, protected sectors, and preferential public 
procurement - all key weapons in the dirigiste arsenal - as trade-distorting practices. Dirigiste industrial policy was decreasingly viable, given the weakening of traditional policy instruments, advancing Europeanisation, and a Commission policing competition with increasing vigour. Yet volontariste instincts and policy approaches endured, despite the French government's means to direct the economy (through the 'old-style' dirigisme of the Mitterrand experiment) being undermined.

French Socialists' dirigiste aspirations endured, and indeed revived in the mid to late 1990s, particularly in the field of employment policy where the laissez-faire approach failed so miserably in the 1980s and early 1990s (Lordon 1998). French Socialists recognised the constraining context of the post-Bretton Woods international political economy, but sought to carve out dirigiste policy space. This policy space was illustrated between 1997 and 2002 by attempts to find a new path to full employment. In the face of macroeconomic constraints at the national level, they sought to transcend these by pursuing a dual-level strategy. This combined national level reforms with a reorientation of the process of economic integration towards greater emphasis on employment, creating a new dirigiste policy space at the European level:

As the Prime Minister [Jospin] is often saying, the problems of growth and unemployment are also European problems ... that is why the strategy for fighting unemployment has two facets: a national dimension, and a European one seeking to re-orient European construction in favour of jobs and growth. (Muet 1998: 85)

The successes and failures of this strategy are discussed below after providing historical context by briefly discussing the 1983 U-turn and competitive disinflation. This chapter then proceeds by setting out how the French Socialists sought to secure credibility and then create and exploit dirigiste policy space.

\section{The U-turn, competitive disinflation and the 'long game'}

The Mitterrand era began in 1981 with an ambitious 'redistributive Keynesian' (Hall 1986) demand boost and a dash for growth in the context of a world slump. However, within two years, a ballooning trade gap led to balance of payments problems which generated financial crises. The resultant external pressures, perhaps most importantly in the form of commitments involved in staying in the European Monetary System (EMS), proved incompatible with this macro-economic stance and by mid-1982 it had been abandoned (Hall 1986; Cameron 1996). One policy option in 1983 was a protectionist and dirigiste 'solution' which remained within 
the established referential of French economic policy-making. Mitterrand received representations from both 'camps' right up until the decision was made. The dirigiste approach was rejected in favour of an 'ordo-liberal' (see above), anti-inflationary and market-conforming solution. This accepted EMS conditions for revaluation, and a distinctly German-influenced conception of what constituted sound macroeconomic policy, and indeed macro-policy making institutions.

This was a pivotal moment for French Socialism, and the nature of France's engagement with the international economic context. Once the decision to remain part of the EMS was taken, the 'appropriate' path of development was conceived in very narrow ordo-liberal terms, despite the absence in France of the wider framework of (corporatist) institutions upon which German ordo-liberalism is predicated. The effects of the 1983 policy choice were, in Cameron's term, 'regime defining':

In failing to negotiate a devaluation immediately upon entering office, in failing later to negotiate devaluations large enough to offset the cumulative inflation differential with Germany, and, ultimately, in failing to leave the EMS the government consigned itself to remaining in the EMS with an over-valued currency. In so doing, it consigned itself to the pursuit of an orthodox deflationary policy marked by fiscal restraint and tight money that inevitably resulted, over time, in low growth and high unemployment. (Cameron 1996: 75)

The French case is often cited as powerful testament to the power of global finance to erode policy autonomy. As Lordon notes of the 1983 U-turn, 'this major shift, in fact, corresponds to the acknowledgement by the Socialists of the new rules of opened and internationalised economies' (1998: 96; see also Halimi et al. 1994). The 'competitive disinflation' strategy (Lordon 1998) was pursued by the Socialist, hitherto dirigiste, governments after 1983. It assumed the route back to a full employment economy lay not with Keynesian macroeconomic demand management, or dirigiste interventionism, but microeconomic manoeuvres to bring market discipline to bear in order to improve French firms' competitiveness in the context of tight budgetary discipline and a strong currency.

Finance Minister Bérégovoy implemented a macroeconomic strategy of 'competitive disinflation'. The logic is simple, 'under fixed exchange rates, a country with higher inflation loses competitiveness, and as a result demand for output falls. An increase in unemployment follows which makes inflation decrease sufficiently so that competitiveness is eventually re-established' (Fitoussi et al. 1993). The strategy was a crucial determinant of all aspects of economic policy from 1983 onwards. Competitive disinflation comprised three elements. First, the nominal stability of the franc fort, pegged to the DM. Second, wage restraint and wage discipline, 
initially through a de-indexation of wages, and third, the prioritising of public deficit reduction (Lordon 1998: 103-5).

The causes of the paradigm shift in the referential from dirigiste macroeconomic framework and credit rationing to the market and rules-based ordo-liberal regime are to be found not only within French politics, but also in the changing European, and global, political economic conditions (see Clift 2003 a and b). The policies pursued between 1981 and 1983 displayed an incompatibility with the post-Bretton Woods international economic context, and after 1983, competitive disinflation was to an extent a reflection of changed economic realities. As Lordon notes, 'the 1983 decision was grounded on a strong - even if somewhat fuzzy - European commitment, based on an acceptance of the evolution of the world economy'(1998: 102). Desires to facilitate European construction, and shift the macroeconomic framework so as to be consistent with European priorities, were reinforced by domestic priorities and budgetary constraints. The French state's severe lack of funds, and cavernous trade gap, had presented serious problems when funds were diverted to defending the franc against repeated speculation.

Currency crises demonstrated the need to secure credibility with financial markets as a precondition of any political economic strategy. Competitive disinflation illustrated this centrality of credibility within the French Socialist mindset. French Socialist policy elites have, since the 1980s, achieved their main macroeconomic policy goals in the context of European integration by committing to stability-bolstering rules. This was part of a wider strategy, or 'long game' - to use the credibility gained through competitive disinflation, and thereafter a strongly German influenced architecture of EMU, to expand their room to manoeuvre in economic policy. Subsequently, once credibility had been achieved, French Socialists sought to rewrite and reinterpret the rules (Clift 2003b and 2006).

Within the Maastricht negotiations, French Socialists' aspirations for more volontarisme to counter the perceived 'monetarism' of the European Central Bank (ECB) crystallised into the proposal for an 'economic government' (EG) as a political counterweight to the ECB (Dyson and Featherstone 1999: 172-245). The proposal had eventually to be sacrificed in the face of unstinting German hostility. Such political influence was counter to the German model, and the Maastricht Treaty explicitly outlaws such interference. Nevertheless, the political support and the opportunities for the kinds of reorientations to EMU that the likes of Mitterrand and Bérégovoy had sought at Maastricht presented themselves in the years immediately following its inception in 1999. The stability and growth pact (SGP), the budgetary policy rules limiting deficit and debt levels for euro members, had secured credibility for France and other European members. This 
credibility, in combination with the political context of a Franco-German axis on deficit forgiveness, created areas of room for manoeuvre, notably in revising the interpretation and implementation of the SGP to align more closely with French dirigiste preferences.

\section{French socialism and dirigiste aspirations for European economic governance}

In 1997, the Jospin Government's attempts at institutional re-engineering of the supranational economic policy regime advocated a political role in the determination of exchange rates, and a balancing of stability with other economic priorities, notably employment and growth (Clift 2003a). Jospin's four 'conditions' on the transition to the euro of the 1997 election manifesto (PS 1997: 12-13) distilled the diverse elements of the dirigiste aspirations of French Socialists. Notably, Jospin insisted that, alongside the ECB, there must be established 'a European economic government, representing the people and charged with co-ordinating the economic policies of the various nations'. Jospin further argued that 'Europe must be social and political,' therefore, 'we want the relations between participating euro countries be founded not on an austerity pact [an explicit reference to the German-inspired SGP], but on a solidarity and growth pact, permitting policies in favour of job creation and social cohesion' (PS 1997: 12-13).

In April 1999, then Finance Minister Dominique Strauss-Kahn offered a further iteration of dirigiste French preferences in relation to the SGP and economic government. The euro, he argued, 'should make us more autonomous in the conduct of our economic policies', and this autonomy should be directed towards the 'political priority' of employment and growth (StraussKahn 1999). Specifically, Strauss-Kahn argued: 'Fiscal policies, within the framework of the Stability and Growth Pact, should promote strong and sustainable growth, especially in the event of a sharp drop in activity. This assumes that we accumulate enough room for manoeuvre during periods of high economic growth so that automatic stabilisers can be allowed to act when the economy slows down'. The aim being to 'enable automatic stabilisers to play their full part . . . [making] fiscal policy an instrument for smoothing out ups and downs in the economy without compromising objectives for correcting structural deficits' (Strauss-Kahn 1999).

Pisani-Ferry (Jospin's chief economic adviser) advocated 'a suitable policy mix for the Euro zone through coordination and dialogue'. The path to full employment entailed, for him, a 'balance between monetary and budgetary policies and between macro-economic and structural policies' in the context of a 'macro-economic policy that can take risks in favour of growth and employment' (2000: 23-4). 
In May 2001, Jospin renewed calls for the full establishment of the 'economic government' of Europe in a speech setting out his European agenda (Jospin 2001). Pisani-Ferry and then Trade Commissioner Pascal Lamy further elaborated French Socialist euro reform proposals (Lamy and Pisani-Ferry 2002). Celebrating the creation of the Eurogroup as a 'notable success' of the 'French left's European project' (2002: 49-50), they contrasted this favourably with 'a Europe constructed on rules and procedures, whose ideal model of the world seems to be one in which there would no longer be a need to make discretionary decisions' (2002: 51). Criticising the ECB inflation target of a price increase of between 0 and 2 per cent as 'inappropriate' (2002: 110), they noted 'while the Americans have given an equal weighting to monetary stability and growth, the Europeans have decided to give their central bank the narrow task of ensuring price stability' (2002: 109).

Lamy and Pisani-Ferry advocated 'a more French model', 'based on an institutionalized dialogue [between the ECB and] the political authorities (Eurogroup and Council)' (2002: 111), a strengthening of the Eurogroup (2002: 116), and a symmetrical target for inflation (potentially committing the ECB to re-flation if inflation drops too low) in a range between 1 and 3 per cent. The dirigiste justification for these reforms is that "economic policy does not boil down to a collection of disciplines and rules of good conduct ... there are times when it is necessary to have the ability to decide and act' (2002: 114). The aim was to preserve 'the proper management of budgetary policy' and its 'role as an instrument of national economic policy' (2002: 115). Pisani-Ferry and Lamy betray the influence of Karl Polanyi over their dirigiste position in their reservations about untrammelled free markets, recognising the potentially 'pernicious effects of a market-controlled economy' (Polanyi [1944] 2001: 80):

there are those who, in the fashion of the gold standard of the nineteenth century, seek to depoliticize the currency, ensure that it is managed as much as possible by a set of fixed rules, placing the onus on societies to make the adjustments required for monetary stability ... on the other hand, there are those who, in the tradition of the twentieth century, regard monetary policy as one of the instruments of an active macroeconomic policy, which takes responsibility for reacting to shocks and attempts to minimize the adjustments imposed on society. These two views are both compatible with the goal of price stability and a scrupulous respect for the central bank's independence ... this key choice [between rigid rules and political discretion] underlies all the debates about the single currency. (Pisani-Ferry and Lamy 2002: 77)

French Socialists share Polanyi's reservations about the danger of subordinating 'the substance of society itself to the laws of the market' (2001: 
$75)$, and the need for the 'protective covering of cultural institutions' (Polanyi 2001: 76) to contain the fundamental contradictions inherent in the laissez-faire self-regulating market system. Accordingly, the French Socialists' approach to European economic governance continually emphasised the discretion of national economic policy-makers over EU-level rules. Dyson notes that the French Socialists 'sought to draw a line between embracing rules of 'sound' public finance and money and taking on the whole apparatus of neo-liberal and monetarist policy discourse' (1999: 202). The mooted balancing of stability with other economic priorities, notably employment and growth, was alien to traditional German 'ordoliberal' monetary arrangements. Nevertheless, the Jospin Government continued to flex dirigiste muscles in order to pull macroeconomic policy levers in the face of low growth, which had been slowed down by prohibitive interest rates and unemployment in excess of 10 per cent (Moscovici 1997: 58). The aim was for a negotiated rebalancing of the policy mix, notably carving out a role for economic and social policy geared towards growth and jobs.

\section{Jospin's socialism: domestic volontarisme, employment creation and redistribution}

The failure of all French governments in the 1980s and early 1990s to deliver on pledges to reduce unemployment led to a re-evaluation of Socialist economic strategy. Too much, it was felt, had been sacrificed at the altar of economic orthodoxy, with resultant gains in financial credibility and profitability, but not jobs. The set the tone for Jospin's 1995 presidential manifesto:

We must learn the lessons of the past, in order to instigate the reorientations of economic policy which today are necessary and possible without increasing the public deficit, nor putting our currency, our external balances, or the competitiveness of our firms in peril. I reject the idea that the state is powerless, and believe that it should deploy all its capacities to aid job creation. (Jospin 1995)

The Jospin Government came into office in 1997 committed to dirigiste activism to tackle unemployment and a number of redistributive social and economic policies. The need to be seen to be credible by investors and speculators, Jospin argued, did not rule out policy activism (1995, 1999). A questioning of the dominant economic orthodoxy informed the philosophical foundation of 'Left Realism'; an insistence upon the existence of 'marges de manoeuvre' (room for manoeuvre), and a belief that all the means of tackling unemployment had not been explored (Clift 2003a). While accepting the need to reduce public deficits, and meet Maastricht 
convergence criteria, Jospin insisted on sufficient room to manoeuvre to change the priorities of the system. The 1997 budget was modified in the wake of the change of government, with new spending and supplementary taxes, in particular on firms. Overall, however, "not wishing to interrupt the up-turn, the state's budgetary policy in 1998 was next-to neutral' (OFCE 1999: 17). The Solidarity Tax on Wealth (ISF) was made more progressive. It was increased in the 1998 budget, its coverage was extended to close a number of loopholes, and a new band introduced in the 1999 budget (OFCE 1999: 19, 63). In 1998, part of the receipts from increased growth went into reducing the public deficit, whilst part went into active expenditure. More redistributive measures were introduced in the 1999 budget (OFCE 1999: 19, 63; PS 1997: 6-7)

From 1998 onwards, the fruits of economic growth enabled more social security spending to be combined with an incremental deficit reduction strategy so as not to hinder growth. Public spending accelerated in 1999 $(+2.4$ per cent in volume, compared with an average of 1.2 per cent increase 1993-97) (Dupont 2001: 63-5). The role of automatic stabilisers retained its importance within the French fiscal policy framework (Clift and Tomlinson 2004). This, combined with some redistribution to lower income brackets with a higher propensity to spend, was a means of keeping demand buoyant during the growth period. Purchasing power as a proportion of household revenue increased by 16 per cent between 1997 and 2000. The existence of room for manoeuvre was demonstrated by the 15 per cent tax levied on non-reinvested profits (reduced to 10 per cent in 1999) by the Jospin Government in 1997, justified in terms of the need to reduce the budget deficit in order to meet the convergence criteria. This was replaced in 2000 , by a contribution sociale on profits to part finance reduced social security contributions for lower earners. Furthermore, a number of exemptions and tax breaks for firms were removed (Dupont 2000: 68-9).

Although remaining within the framework of a commitment to stability, the strategy had a Keynesian feel to it. Firms had to anticipate solvent levels of demand - which presupposed mass consumption, and therefore higher salaries. This explains the commitment to limited redistribution from capital to labour, particularly towards those lower earners with a higher propensity to spend, albeit tempered by an appreciation of the importance of the profitability and competitiveness of firms. While careful to point out that this was not a return to old-style Keynesian policies, the different ideological suppositions underpinning this different view of the economy were explicitly highlighted (Moscovici 1997: 59-60).

Dirigisme in employment creation was a core theme of the Jospin government. Nowhere was the state's enduring role in the job-creation strategy 
more in evidence than in the Jospin government's orchestrated shift to a 35-hour week, aiming to reduce unemployment and to have a redistributive effect between labour and capital. The law which the Assemblée passed in 1998 emphasised job creation, with state aid in the form of reductions in social security contributions offered to firms creating new jobs as a result of the reduction of the working week. The fixed levels of these state financial aids meant they were relatively more generous for lower earners (Milner 2002).

In ideological terms, the 35-hour week policy was a rejection of the neoliberal interpretation of globalisation, and its implications for structural reform of labour market institutions. The 35-hour week was integral to the French Socialist 'model' of capitalism, which prioritised employment (PS 1996). Such new social democratic employment policies indicated an activist role for the state in a strategy compatible with an open economy in a globalising world. The 35-hour week involves negotiated redistribution among workers as a means of furthering social democratic egalitarian employment policy. As Fitoussi puts it, 'workers have to agree to share both their jobs and their salaries with the unemployed' (1998: 81). The 35-hour week stands out as a slight return to the 'heroic' policy-making style of earlier dirigiste French governments (Schmidt 1996: 50-5). The estimated Fr 110 billion cost of the policy was met through a mixture of 'cost-shuffling' and increased public debt (Levy 2001: 204).

In the run up to the 1997 election, the PS manifesto noted: 'Only an engagement of public power can triumph over massive unemployment. A master budget, re-orienting public expenditures towards employment, will be a powerful lever of action'. 'Active' employment policy takes a number of forms, from apprenticeships, and work placements, to state-subsidised jobs, and employers' social security exemptions. These targeted particular groups 'excluded' from the labour market, notably the long-term unemployed, the uneducated and young people. These groups have borne the brunt of increased labour market flexibility in France.

The Jospin Government insisted upon the role of the state as guarantor of employment, using public sector job creation to tackle unemployment. The resources devoted to employment policy increased markedly, reaching 4.5 per cent of GDP in 2000 (Ministère des Finances 2001: 15). The French Socialists' Plan Aubry pledged to create 350,000 public sector jobs, which, it was anticipated, would be matched by 350,000 new private sector posts. The state's role as employer within an active employment policy remained central to the PS approach. The results of the Plan Aubry were encouraging, with 274,900 jobs created in the public sector by March 2001, and a total of 308,000 private sector jobs under the Plan Aubry framework. The 2001 budget included measures further expanding state employment. In all, 
25,000 new emplois-jeunes were created in 2001 (Ministère des Finances 2001: 9).

The commitment to credibility was a linchpin of the Jospin political economic strategy, and his commitment to a safe transition into the euro was testament to that. Moreover this proved compatible with a wide-ranging, dirigiste and at times redistributive domestic economic and social policy agenda. These measures, in conjunction with a favourable macroeconomic context provided by a 'soft' euro, enabled the Jospin Government to claim some successes on the employment front between 1997 and 2001. Unemployment fell below 10 per cent in 2001, with a total of 2,371,300 unemployed - down from 3.2 million (12.5 per cent) when Jospin took office. He spoke about the creation of a full employment society - unheard of in France since the dramatic policy U-turn of 1983. That said, with the downturn in 2001-2, unemployment began to creep up.

\section{Moving the goalposts: French fiscal policy, EMU and the SGP: constrained discretion, or discrete latitude?}

Turning now to the supranational institutional re-engineering element of the French Socialists' dirigiste dual-level strategy, it was under Prime Minister Juppé's right-wing RPR Government that the reorienting process began, at the Dublin European Council in 1996, with the (cosmetic) insertion of the word growth. Under the Jospin Government, the reorientations would take on a much more concrete, politically and economically significant form. French macroeconomic policy thinking was always more equivocal about the 'sound money and finance' agenda which inspired the Pact's rules. Attempts to rebalance the relative importance of acceptance of the German model in the pursuit of 'sound money' with more familiar, French dirigiste elements have been most consistently and successfully pursued in relation to the SGP.

Jospin's European Minister Moscovici highlighted the price paid for anti-inflationary myopia in terms of low growth, slowed down by prohibitive interest rates and mass unemployment. "That is why such dogmas are today seriously challenged, not only on the grounds of social justice, but also on the grounds of economic efficiency' (1997: 58). The aim of the Jospin Government in the area of European economic governance, as noted above, was for a negotiated rebalancing of the policy mix. At its most ambitious, dirigiste aspirations hoped to generate coordinated fiscal, monetary and structural policies across the EU which would be geared towards jobs and growth. The strategy was one of continued critical engagement from within - arguing at every turn for reorientations, such as a European Jobs 
and Growth Pact (at the Amsterdam European Council), and a European Growth fund (at the Portschach European Council) (Clift 2003b).

As the economic slowdown, beginning in 2001, gathered momentum, the 'long game' French Socialist policy-makers had been playing with EMU began to bear fruit. The credibility-bolstering rules-based regime and the earlier fiscal consolidation generated policy-space which was exploited by the Jospin government in its redistributive, indeed opportunistic, tax cutting in 2000. The macroeconomic stance of the Jospin Government betrayed a certain antipathy towards the constraints of the SGP, which incurred the Commission's wrath. The Jospin Government's use of the cagnotte (tax windfall) to increase public expenditure and delay public sector reforms aimed at reducing spending, rather than reduce deficits, illustrated the power of dirigiste instincts. As Howarth notes, the "stabilisation goal of "economic government" was clearly not prioritised by the Jospin Government - despite the constant assurances of Socialist finance ministers to their Euro-Zone counterparts and the international financial markets' (2004: 20).

This set in train the almost inevitable French breaches of SGP targets that were to follow between 2002 and 2004. This provided the background to what would become, under the Raffarin Government, a period of "unrepentant sinning' (in the eyes of the European Commission) (Creel et al. 2002). Credibility nevertheless continued to be an important concern for the Socialists, rhetorically at least. They pledged, in the context of the 2002 election campaigns, to respect the SGP conditions, and accurately criticised Chirac's profligate tax-cutting plans as incompatible with European commitments (Howarth 2004: 22). One can only speculate as to whether this pledge would have been honoured had Jospin won, although the policy record 1997 to 2002 suggests it probably would not.

One notable achievement of French objectives has been the appointment of a formal leader of the Euro-group (of Euro-member economics and finance ministers), as French Socialist finance minister Fabius had called for in 2001. French aspirations for a strengthening of the Euro-group also received a boost in the wake of agreements to elect the leader of the group as of the beginning of 2005. The role and significance of elected politicians, through the Euro-group, was further enhanced.

Although the French Socialists were not in power and therefore not directly involved in its revision, it is notable that revisions to the SGP were consistent with their preferences noted above. The Commission's 2004 SGP revision proposals addressed explicitly 'how the instruments for EU economic governance could be better interlinked in order to enhance the contribution of fiscal policy to economic growth' (European Commission 2004: 2). That this refrain recalls the volontarisme characteristic of French dirigiste approaches to macroeconomic policy, and could have been taken 
from a speech by Bérégovoy or Mitterrand in the early 1990s, illustrates the fruits the 'long game' has borne.

French dirigiste desires for more political interpretation and discretion in applying the Pact's rules have been substantially realised. Key shifts include a more differentiated approach to deficits, notably which aspects of public expenditure are included in deficit calculations, and a widening of the definition of the exceptional circumstances clauses permitting a breach of the 3 per cent deficit target. This has generated more fiscal room for manoeuvre by governments in interpreting and enforcing the Pact. French Socialists continue to champion a 'political' reading of fiscal rules in keeping with their volontariste and dirigiste policy traditions.

\section{Conclusions}

The analysis presented here highlights the PS's economic and social policy activism, which sits uncomfortably with neo-liberal versions of the implications of the global economy for social democratic governments. Credibility was central to the French Socialist government's strategy, as it must be within any political economy of social democracy, in the context of deregulated financial markets slow to trust governments of the left. Augmenting credibility through the process of European construction was an important dimension of French Socialist political economy, but it did not undermine the government's broader social democratic ambitions.

The record of the Jospin Government demonstrates the potential for combining credibility with social democratic policy activism in a world characterised by globalisation. A crucial facilitator of this was the credibilitybolstering qualities of EMU. So solid have been the ordo-liberal sound money and finance foundations of the EMU project, and the prevalent perceptions arising from them, that French Socialists were able to attenuate, indeed neglect, budgetary rigour, without a loss of confidence and credibility. The virtues of sound money and sound public finances remain a priority - but they now coexist with other priorities. The potential for conflicts and tradeoffs between 'sound finance' and jobs and growth has been recognised, as has the need to allow the free play of automatic stabilisers, without straitjackets of tight, deficit rules insensitive to the economic cycle, or economic circumstances. Credibility could be retained whilst breaching (for 'sound' economic reasons given the economic conjuncture) the rules.

The 'long game' has borne fruit in terms of enhanced policy autonomy. France's budgetary policy was unconstrained and supported growth between 1999 and 2001, and became sharply expansionary in 2002. Although the electoral losses of 2002 meant the Socialists were only spectators in later phases of the 'long game', the shape of subsequent 
evolutions of the SGP and Euro-group have nevertheless been consistent with French Socialist preferences outlined above. Aided by stronger growth than many had anticipated, and some dirigiste creative accounting, France has successfully defused the Commission's antagonism without effective constraint being wielded upon its activist, growth-oriented fiscal policy.

In terms of the wider debate about the political economy of social democracy, the Jospin Government demonstrated that the securing of credibility through stability-centric macro policy stances was compatible with social democratic priorities in other areas of economic and social policy. A commitment to stability evidently did not condemn a social democratic government to budgetary immobilisme. This has important implications for the viability of social democracy in a world characterised by globalisation, and presents a challenge to the 'end of social democracy' thesis, and the social democratic crisis literature more broadly.

\section{Notes}

1 Ordo-liberalism is a political science term referring to a German economic ideology which shares some common ground with Anglo-Saxon neo-liberalism. Rooted in the historical experience of hyper-inflation, ordo-liberalism prioritises the constitutional enshrining of central bank independence and price stability (as with the German Bundesbank). More broadly, ordo-liberalism favours market liberalisation (of labour, product and capital markets) and strict, enforceable rules of fiscal discipline (see e.g. Dyson 2002: 174-86, 193-7).

2 Inspired by Karl Polanyi's insights, John Gerard Ruggie has characterised the establishment of the post-war regulated international economic order at Bretton Woods as the era of 'embedded liberalism' (Ruggie 1982). This entailed 're-embedding' (international) economic relations in regulated multilateral international trade and payments regimes, crucially including capital controls. This allowed national governments in advanced economies the domestic policy autonomy to pursue Keynesian full-employment economic strategies and welfare state expansion.

3 L'Hebdo des Socialistes, 9 May 1997, 4.

\section{References}

Balls, E. (1998) 'Open Macroeconomics in an Open Economy', Scottish Journal of Political Economy 45 (2).

Cameron, D. (1996) 'Exchange rate politics in France 1981-83: the regime defining choices of the Mitterrand presidency', in T. Daley (ed.), The Mitterrand Era (London: Macmillan), 56-82.

Clift, B. (2003a) French Socialism in a Global Era (London: Continuum), Chapters 6 and 7.

Clift, B. (2003b) 'The changing political economy of France: dirigisme under duress' 
in M. Ryner and A. Cafruny (eds), A Ruined Fortress? Neo-Liberal Hegemony and Transformation Europe (New York: Rowman \& Littlefield), pp. 173-200.

Clift, B. (2006) 'The new political economy of dirigisme: French macroeconomic policy, unrepentant sinning and the Stability and Growth Pact', British Journal of Politics and International Relations, 8 (3).

Clift, B. and Tomlinson, J. (2004) 'Capital mobility and fiscal policy: the construction of economic policy rectitude in Britain and France', New Political Economy, $9(4)$.

Clift, B. and Tomlinson, J. (2007) 'Credible Keynesianism?: New Labour, macroeconomic policy and the political economy of coarse tuning', British Journal of Political Science, 37 (1).

Cohen, E. (1995) 'France: National champions in search of a Mission', in J. Hayward (ed.), Industrial Enterprise and European Integration: from National to International Champions in Europe (Oxford: Oxford University Press).

Cohen, E. (1996) La Tentation Hexagonale (Paris: Fayard).

Cox, R. (1987) Power, Production and World Order (New York: Columbia University Press).

Creel, J., Dupont, G., Le Cacheux, J., Sterdyniak, H. and Timbeau, X. (2002) 'Budget 2003: Le pécheur non repenti', La Lettre de L'OFCE, 224.

Dahrendorf, R. (1990) Reflections on the Revolutions in Europe (London: Chatto \& Windus).

Dupont, G. (2000) 'La politique economique', in OFCE, L'Economie française 2000 (Paris: La Découverte).

Dupont, G. (2001) 'La politique economique' in OFCE, L'Economie française 2001 (Paris: La Découverte).

Dyson, K. and Featherstone, K. (1999) The Road to Maastricht: Negotiating Economic and Monetary Union (Oxford: Oxford University Press).

Dyson, K. (1999) 'Benign or malevolent Leviathan? Social democratic governments in a neo-liberal Euro area', Political Quarterly, 70 (2).

Dyson, K. (2002) 'Germany and the Euro', in K. Dyson (ed.), European States and the Euro (Oxford: Oxford University Press).

Eatwell, J. (1995) 'The International Origins of Unemployment', in J. Michie and J. Grieve Smith (eds), Managing the Global Economy (Oxford: Oxford University Press).

European Commission (2004), 'Strengthening economic governance and clarifying the implementation of the Stability and Growth Pact', COM (2004) 581, 3 September (Brussels).

Fitoussi, J.-P., Atkinson, A., Blanchard, O., Flemming, J., Malinvaud, E., Phelps, E., and Solow, R. (1993) Competitive Disinflation: the Mark and Budgetary Policy in Europe (Oxford: Oxford University Press).

Fitoussi, J.-P. (1998) Table ronde: Comment appliquer les 35 heures? Revue Politique et Parlementaire.

Giddens, A. (1994) Beyond Left and Right (Stanford: Stanford University Press).

Giddens, A. (1998) The Third Way (Cambridge: Polity).

Gray, J. (1996) After Social Democracy (London: Demos). 
Gray, J. (1998) False Dawn (London: Granta).

Halimi, S., Michie, J. and Milne, S. (1994) ‘The Mitterrand experience’, in J. Michie, and J. Grieve Smith (eds), Unemployment in Europe (London: Academic Press).

Hall, P. (1986) Governing the Economy (Cambridge: Polity).

Held, D., McGrew, A., Goldblatt, D. and Perrraton, J. (1999) Global Transformations (Cambridge: Policy).

Howarth, D. (2004) 'Breaking the rules: the French reconceptualisation of economic government?' Paper presented at the PSA annual conference, Lincoln, April.

Jospin, L. (1995) '1995-2000: propositions pour la France' (Paris: Parti Socialiste). Jospin, L. (1999) Modern Socialism (London: Fabian Society).

Jospin, L. (2001) Ma vision de l'Europe et de la mondialisation. Notes de la Fondation Jean-Jaurès, 25 (Paris: Plon).

Lamy, P. and Pisani-Ferry, J. (2002) 'The Europe We Want', in L. Jospin, My Vision of Europe and Globalization (Cambridge: Polity). (Originally published as L'Europe de nos Volontés Notes de la Fondation Jean Jaurès, 27, January).

Levy, J. (2001) 'Social policy in the age of high unemployment', in A. Guyomarch, H. Machin, P. Hall and J. Hayward (eds), Developments in French Politics 2 (Basingstoke: Palgrave).

Lordon, F. (1998) 'The Logic and Limits of Désinflation Compétitive', Oxford Review of Economic Policy, 14 (1).

Milner, S. (2002) 'The Jospin Government and the 35 hour week', Modern and Contemporary France, 10 (3).

Ministère des Finances (2001) Project de Loi des Finances pour 2002 Les Notes Bleues de Bercy hors série (Paris: La Documentation Française).

Moscovici, P. (1997) L'Urgence: Plaidoyer pour une autre politique (Paris: Plon).

Muet, P.-A. (1998) 'Table ronde: Comment appliquer les 35 heures?' Revue Politique et Parlementaire, 993.

OFCE (2000) L'Economie française 2000 (Paris: La Découverte).

OFCE (1999) L'Economie française 1999 (Paris: La Découverte).

Parti Socialiste (1996) Final text of the National convention Mondialisation, Europe, France.

Parti Socialiste (1997) Changeons d'Avenir: Nos engagements pour la France (Paris: PS Presse).

Pisani-Ferry, J. (2000) 'Full employment: France', in G. Mulgan, J. Pisani-Ferry, P.-A. Muet and R. Layard (eds), Achieving Full Employment (Policy Network: London).

Polanyi, K. ([1944] 2001) The Great Transformation (Boston, MA: Beacon Press).

Rosanvallon, P. (1989) 'The development of Keynesianism in France', in P. Hall (ed.), The Political Power of Economic Ideas: Keynesianism across Nations (Princeton: Princeton University Press).

Ruggie, J. (1982) 'International regimes, transactions and change: embedded liberalism in the post-war economic order', International Organization, 36 (2).

Schmidt, V. (1996) From State to Market? The Transformation of French Business and Government (Cambridge: Cambridge University Press). 
Schmidt, V. (1997) 'Running on empty: the end of dirigisme in French economic leadership', Modern and Contemporary France, 5 (2).

Strauss-Kahn, D. (1999) 'For a European Growth and Employment Pact', 21 April 1999: www.finances.gouv.fr/archives/communiques/c9904212.html, accessed 25 February 2005.

Zysman, J. (1983) Government, Markets, Growth: Financial Systems and the Politics of Industrial Change (Ithaca: Cornell University Press). 


\title{
The Spanish Socialist Workers' Party: continuity, innovation and renewal
}

\author{
Paul Kennedy
}

The Spanish Socialist Workers' Party (Partido Socialista Obrero Español PSOE) was founded in Madrid in 1879. It was the largest party on the left during the Second Republic (1931-36), and provided the Republic with two prime ministers during the Spanish Civil War, Francisco Largo Caballero (1936-37) and Juan Negrín (1937-39). Brutally repressed by the Franco regime (1939-75), the PSOE almost disappeared as a significant political force within Spain. Nevertheless, under the leadership of Felipe González, the party was able to establish itself as the chief opposition party at general elections in 1977 and 1979. The party then went on to win four consecutive general elections in 1982, 1986, 1989 and 1993 (the first three with an overall majority) and was only narrowly beaten at the 1996 general election. Experiencing its worst general election result in two decades four years later, the PSOE was nevertheless able to return to office at the 2004 general election under the leadership of José Luis Rodríguez Zapatero. The party repeated its victory at the general election held in March 2008. Should the party complete its current four-year term (2008-12), the PSOE will have been in office for twenty-two of the thirty years between 1982 and 2012. The PSOE is therefore not only one of Europe's oldest social democratic parties, but also one of the continent's most electorally successful over recent decades.

This chapter considers the evolution of the PSOE from its re-emergence as a significant political force during the 1970s until the present day under José Luis Rodríguez Zapatero. Intensely conscious of its long history, the PSOE has been keen to emphasise its continuity with the party of the past, and the PSOE's research foundation, the Fundación Pablo Iglesias, regularly produces items relating to the party's history. However, it has been the PSOE's capacity for renewal and innovation, rather than the party's continuity with the past, which has been the key to its electoral success over recent decades. Once Felipe González became party leader in 1974, 
he implemented a set of reforms which amounted to a virtual refoundation of the party, converting it into a formidable election-winning organisation. Nevertheless, when the party lost office in 1996 after almost fourteen years, it initially showed itself to be a singularly ineffective opposition party, appearing incapable of winning back the support of the Spanish electorate. It was only after a protracted leadership crisis, and the appointment of José Luis Rodríguez Zapatero as leader in 2000, that the PSOE was able to carry out a wide-ranging process of renewal, incorporating ideological, programmatic and organisational elements, which enabled it to present itself once again as a credible party of government. Moreover, the renewal of Rodríguez Zapatero's mandate at the March 2008 general election effectively neutralised charges that he was simply an 'accidental' prime minister, who owed office to the particular circumstances in which the 2004 general election took place, just days after $\mathrm{Al}$-Qaeda terrorist attacks on Madrid.

The chapter adopts a chronological approach. First, the party's transformation from near irrelevance into a party of government under Felipe González will be considered, whereby the leadership's uncompromising control over the party was used to moderate the PSOE's ideological positions within the context of a party discourse which emphasised internal discipline and unity. The party's main achievements in office under González will then be covered, together with an analysis of the factors which led to the party's defeat in 1996. The party's troubled period in opposition between 1996 and 2004 will be examined next, including an analysis of the party's recovery under Rodríguez Zapatero from 2000. The chapter will conclude with a discussion of the PSOE's period in office since 2004.

\section{The re-emergence of the PSOE and the pursuit of office 1974-82}

When Felipe González was appointed leader of the PSOE in 1974, the party had effectively become marginal to developments within Spain. The previous, ageing leadership based in Toulouse had found itself increasingly out of touch with a Spain which had undergone a profound social and economic transformation during the 'economic miracle' of the 1960s. González's task was therefore to adapt the party to these new realities. Furthermore, he had to ensure that his party was able to compete on the left with the larger and better-organised Spanish Communist Party (Partido Comunista de España-PCE), which had been a more prominent force of opposition to the Franco regime.

In the context of the period immediately after Franco's death in 1975, the adoption of a Marxist identity was viewed as being essential if the PSOE was to establish its credentials as a key opposition force; from this perspective, 
rejection of the Francoist state demanded the rejection of capitalist society (Juliá 1997: 509). Consequently, for the first time in the party's history, the PSOE defined itself as a Marxist party at its congress in 1976. Once the PSOE had established its hegemony on the left at the general election of June 1977, when the party came second to Adolfo Suárez's Unión de Centro Democrático (Democratic Centre Union - UCD) with just under 30 per cent of the vote, the Marxist tag had outgrown its usefulness, and indeed had become something of a liability. The PSOE's failure to improve significantly on this result at the 1979 general election convinced the leadership that the party's Marxist label was hindering further electoral progress. Unable to convince the party of the need to drop its Marxist self-definition at the party's congress held shortly after the 1979 general election, González resigned as leader. Significantly, the congress also approved organisational changes which strengthened the hand of the leadership. Whereas each local party branch had hitherto been entitled to send a delegation to vote at congress, delegations would thereafter be formed at the provincial and regional level. Furthermore, a form of block vote was introduced (Heywood 1994: 10; Juliá 1997: 540-1).

By the time that an extraordinary congress was held in September 1979 to decide on the issue of the leadership, the effect of the organisational changes was clear. Whereas one thousand delegations had attended the congress in May, just fifty did so four months later. Alfonso Guerra, who in addition to being González's deputy headed the Andalusian delegation, wielded 25 per cent of the total vote. The leadership's victory was therefore assured. The importance of Marxism within the party's statutes was downgraded and González was overwhelmingly re-elected and was thereafter able to strengthen the leadership's control of the party. The re-positioning of the party further towards the centre of the political spectrum followed. The connection between internal organisational reforms and the shift towards ideological moderation was therefore clear as the party sought to broaden its electoral appeal (Méndez-Lago 2005: 175). Confirmation of the efficacy of the strategy was provided when the PSOE won an overall majority at the general election of October 1982, almost doubling the number of votes it had obtained at the previous general election. By now a modern, moderate, catch-all party, the PSOE dominated the political scene.

\section{The PSOE in office 1982-96}

Throughout the remainder of the 1980s, the PSOE was notable for the undisputed leadership of González, the tight discipline imposed on the party by Alfonso Guerra, and a political discourse which emphasised the importance of party unity. All three of these elements were considered essential 
given the scale of the tasks confronting the party when it entered office. One issue which could no longer be delayed was the implementation of an effective economic policy. Such had been the pressures on the PSOE's UCD predecessors in government to safeguard the delicate transition to democracy that the dire state of the economy had received insufficient attention. Unemployment, inflation, faltering GDP growth and a burgeoning public sector deficit all required immediate attention.

Having learned from the failure of their French Socialist counterparts' attempt to prosecute a Keynesian-style economic policy, the Spanish Socialists chose not to pursue a similar strategy. Socialism was downplayed while emphasis was given to the need to carry out a wide-ranging programme of modernisation, which was viewed as being virtually synonymous with 'Europeanisation'. Loss-making sectors of industry were closed as part of a programme of industrial restructuring aimed at improving the competitiveness of Spanish industry and tight monetary, fiscal and wage policies were implemented. Although unemployment continued to rise (from 16 per cent in 1982 to 22 per cent in 1986), overall economic performance improved, enabling Spain to become a member of the European Community in January 1986.

From 1986 until the end of the decade, Spain enjoyed the highest average economic growth in the EC. The economic boom nevertheless served to exacerbate tensions between the government and the trade unions, including the Socialist General Workers' Union (Unión General de Trabajadores - UGT). Concerned at the government's failure to take advantage of the economic boom to invest in higher levels of social expenditure, the trade unions convened a one-day general strike on 14 December 1988, which obtained massive support from the Spanish public.

Shaken by the strike, the government relented and increased social transfers significantly (Boix 1998: 131; Kennedy 2001: 55; Méndez-Lago 2005: 178-9). Social spending increased from 23.8 per cent of GDP in 1988 to 27.4 per cent in 1993 (Rodríguez Cabrero 2004: 123). While only 25.8 per cent of those without work received unemployment benefit in 1988, 62.2 per cent did so in 1992; overall spending on unemployment benefit increased by 96 per cent between 1989 and 1992. Education spending, which had already been significant before the general strike, also increased from 3.9 per cent of GDP in 1984 to 4.5 per cent in 1992 (Marín 2001: 421,424). Increases in health expenditure enabled the entire population to have free access to health care by 1992; a decade before, when the PSOE entered office, six million Spaniards had no access to public health care at all. Minimum pension rights were similarly extended to cover the entire population (Tezanos 1992: 39).

Total public sector spending was almost 50 per cent of GDP by 1995, the 
PSOE's last full year in office, of which outlays on the welfare state (pensions, unemployment benefits, health, education, housing and other social services) accounted for around half, in line with the EU average (Chislett 1996: 28). The bulk of this spending came in the period following the general strike. On this increased level of public spending, Miguel Ángel Fernández Ordóñez, who was junior minister within the Trade Ministry between 1986 and 1988, has commented: 'The main defect in the field of economic policy was undoubtedly the explosion in public spending between 1988 and 1990. It was probably the Government's weakness after the 1988 general strike which explains the excessive growth of public spending during that period' (Iglesias 2005: 739). Joaquín Almunia, who succeeded González as party leader between 1997 and 2000, also confirms the significance of the general strike on the government's fiscal policy stance. Increased social expenditure was 'a response to the empty streets which we saw on 14 December 1988. This has been much criticised ever since because it was not backed up by an orthodox economic policy. And that is where we made our greatest mistake in economic policy' (Almunia 1998: 26).

Whether the government's decision to increase social expenditure in the wake of the general strike was indeed an error, it certainly provided the less affluent with a significant level of redistribution of income, thereby supporting the PSOE's credentials as a social democratic party prepared to translate its ideological preferences into concrete actions. The curious situation therefore existed whereby the key role played by the general strike in the subsequent increase in social spending led the PSOE to adopt a somewhat ambivalent approach towards what constituted its most classically 'social democratic' achievements. Unable to resist the demands which found expression in the general strike, the government increased social spending while refusing to increase taxes further, allowing the public deficit to increase, which ultimately proved damaging to the Spanish economy during the early 1990s (Boix 1996: 367). The political capital gained by the increased levels of social spending was therefore undermined somewhat by the subsequent recession.

The general strike also proved to be a watershed in the PSOE's relationship with the UGT: the PSOE dropped its statutory requirement for party members to join the UGT in 1990. The crisis in party-union relations nevertheless did not prevent the PSOE from winning a third consecutive general election victory in October 1989, when it obtained precisely 50 per cent of the seats in the Spanish lower house, the Congress of Deputies. With the economy still booming, the PSOE faced the new decade with considerable confidence.

The 1990s nevertheless presented the PSOE with a number of challenges which it was ultimately incapable of overcoming. The economy entered 
recession in 1992, thereby undermining the government's economic credibility and forcing it to curtail the increased spending on social provision which had been a key element of policy since 1988. A simultaneous succession of corruption scandals involving figures connected to the party - ranging from illegal financing of the party to government involvement in the establishment of death-squads targeting suspected ETA members similarly served to weaken its political authority. There was also a breakdown in the party's much-vaunted discipline as confrontations increased between the supporters of the PSOE's Deputy Leader, Alfonso Guerra, the guerristas, and those opposed to Guerra's influence within the party, the renovadores. Although more of a naked battle for power within the party than a clash over differing ideological approaches, it is significant that González ensured that Guerra's influence fell short of the crucial Finance Ministry. Successive Finance Ministers, Miguel Boyer, Carlos Solchaga and Pedro Solbes, were all advocates of an orthodox economic policy capable of retaining the confidence of the financial markets. For Guerra, it was "not a PSOE government, but a coalition government between the PSOE and the Finance Ministry' (Burns Marañón 1996: 168). González significantly remarked that Spain was 'governed from the Moncloa [the prime minister's official residence] and not Ferraz [site of the PSOE's HQ]' (Heywood 1994: 17).

In this context, the Spanish political scene became more competitive as the opposition Popular Party (Partido Popular - PP), since 1990 under the leadership of José María Aznar, gained from the PSOE's difficulties. The PSOE's significant achievements in the fields of welfare provision during the early 1990s nevertheless contributed towards the party being able to retain power - albeit by a relatively narrow margin - at the June 1993 general election. Dependent on the support of nationalist parties to remain in office, and unable to reverse the decline in its political and economic credibility, the PSOE was nevertheless defeated by the PP by the comparatively slender margin of 1.4 per cent of the vote at the March 1996 general election.

The party left office with a number of significant achievements to its credit: democracy had been consolidated; greater economic efficiency had been achieved; a basic welfare state had been established and a significant level of redistribution had taken place. Moreover, Spain had established itself as a medium power within the European Union. Having won four consecutive general elections, the PSOE had been capable of sustained electoral success at a time when social democracy was generally considered to be on the defensive before the challenge of the New Right.

While certain commentators have portrayed the party's economic policy orientations as reflecting neo-liberal precepts (Share 1988; Petras 
1993), it has also been argued that the PSOE's economic policy could more accurately be characterised as a pragmatic response to economic constraints over which the socialists had little control (Heywood 1994: 1; 1995: 227). Either way, it should be emphasised that the PSOE government's social democratic ideological preferences did find expression in massively increased welfare provision. Furthermore, taxes were increased by one-third, while the public sector was used to develop the most extensive capital formation plans in Europe in the 1980s (Boix 1996: 24). The PSOE government of 1982-96 therefore appears to bear out the hypothesis that the ideological preferences of social democratic parties can still find expression in economic policy. As one commentator has argued: 'There are still choices to be made - even if these have become more expensive or more difficult to mobilise' (Pierson 2001: 88).

\section{The PSOE in opposition 1996-2004}

It is perhaps not surprising that the PSOE had difficulty coming to terms with its diminished status as Spain's chief opposition party after having been in office for so long. It is nevertheless indicative of the torpor within the party that when González resigned as leader at the PSOE's congress in 1997 - after twenty-three years in the post - his decision appeared to catch the party by surprise. González's choice as successor, Joaquín Almunia, was appointed within hours of his resignation. Almunia later admitted that his appointment was a result of 'improvisation' in the context of an emergency situation (Almunia 2002: 470).

Almunia appeared to have more admirers within the party organisation than among the membership as a whole. The new leader's efforts to quash the accusation that he was the party apparatus's man and to consolidate his position within the party led him to introduce a primary election system for the PSOE's candidate to face José María Aznar at the general election due in 2000. That Almunia had overestimated his support became clear when José Borrell, the former Public Works Minister and darling of the party membership, declared his candidacy. When the primary was held in 1998, Borrell was the clear winner. Spaniards could only look on in confusion as the two entered into a frantic series of negotiations over who should be considered to be in charge of party policy. Less than a year after replacing Felipe González, Almunia therefore found himself in an unenviable, if not untenable, position. In a further devastating development, it emerged that officials responsible to Borrell during his period as a minister were facing allegations of corruption. Borrell's response was to resign in 1999, leaving Almunia to lead a demoralised party into a general election which was then just a year away. 
When the election took place in March 2000, the PSOE obtained its worst result since 1979, gaining 34 per cent of the vote (125 seats) to the PP's 44.5 per cent (184 seats) in the 350-seat Congress of Deputies. Almunia resigned on the night of the election as soon as the scale of the defeat became apparent.

One positive outcome from the party's two successive election defeats was that it felt impelled to carry out a thorough self-critique. At its congress in July 2000, it adopted a series of resolutions on the causes and consequences of its two successive general election defeats (PSOE 2000: 9-11). These highlighted several failings: the party's internal instability, lack of unity and uncertain leadership had all led to a haemorrhage of popular support. Meanwhile, the majority of Spaniards remained satisfied with José María Aznar's PP government, which had taken full advantage of the upturn in the economy that had been apparent since the mid-1990s. The PSOE had become too engrossed in its own internal affairs, losing sight of the needs of the electorate. Questions such as the renewal of the party's organisation and leadership, and procedures for the selection of party leaders, were of limited interest to the average voter. With respect to its electoral base, the party had lost the vital support of the urban middle classes, thereby becoming 'increasingly divorced from the urban middle class sectors which form the social majority' (PSOE 2000: 9). Consequently, it increasingly relied on the support of the less-educated, low-income sectors of the electorate. Exhausted after its long period in government, it had also lost energy, direction and focus.

The party congress ended with the election as leader of the 39-year old José Luis Rodríguez Zapatero, who narrowly defeated the favourite, José Bono. Although he had been a parliamentary deputy for León, in northern Spain, since 1986, Rodríguez Zapatero had not held even the most minor government post during the party's period in office. Elected onto the party's ruling body, the Federal Executive Committee in 1997, he was nevertheless something of an unknown quantity to the general population, perhaps no great disadvantage given the extent to which the previous generation of PSOE leaders had been tainted by accusations of corruption.

During the early period of Rodríguez Zapatero's leadership, emphasis shifted towards what a PSOE government could offer the individual in terms of the extension of civil rights. The PSOE leader defined himself as a 'social' liberal, rather than an 'economic' liberal. While the British Prime Minister, Tony Blair, had previously looked to the likes of Anthony Giddens for ideological guidance, Rodríguez Zapatero felt more attracted to the ideas of the Irish academic, Philip Pettit, whose conception of republican liberty, or liberty as 'non-domination', has influenced the PSOE leader in the area of individual and social liberties (see Pettit 1997; 2008). With regard to 
the input of, respectively, Pettit and Blair into the PSOE's new 'project', the head of Rodríguez Zapatero's office during his period as opposition leader, and PSOE parliamentary deputy, José Andrés Torres Mora, has commented: 'We had simple political and theoretical instincts and Pettit offered us the analytical background which helped place them within a systematic framework ... I can state quite categorically that Blair's policy has never influenced us much' (Calamai and Garzia 2006: 132-3).

The attempt to distance the PSOE from Blair was also possibly linked to the resentment felt by the party at the closeness of the relationship between Blair and Aznar. A combination of social liberalism and social democracy therefore provided the PSOE with its characteristic ideology under Rodríguez Zapatero, rather than reference to a Blairite 'third way'. Indeed, the pragmatism which was so characteristic of Blair's period in office has been pointedly rejected by Rodríguez Zapatero, who has commented: 'It's important to govern on the basis of principles and carry out a political project founded on profound values. I don't believe in pragmatism, which is just a way of hiding when faced by difficulties' (Carvajal and Martín Casas 2005: 279).

The new PSOE Federal Executive Committee contained just four survivors from its predecessor, which had resigned after the 2000 general election defeat. Largely made up of young Rodríguez Zapatero loyalists, it obtained the endorsement of over 90 per cent of Congress delegates. The party therefore provided a mandate to enable the new general secretary to make a decisive break with the González era and mount the kind of effective opposition to the PP government which had been so markedly absent during Aznar's first term in office.

The style of opposition advocated by Rodríguez Zapatero differed markedly from that of his predecessors, being notably less confrontational. Tangible results of this more constructive form of opposition included the PSOE's readiness to reach agreements with the government on terrorism and the streamlining of the legal process. The PSOE gradually abandoned this strategy throughout the course of 2002 in response to the government's adoption of an increasingly aggressive stance. Key factors in the shift in the PSOE's strategy were government efforts to push through labour legislation with minimum parliamentary debate in June, an unpopular reform of secondary education, and the government's inept handling of the environmental damage caused by the sinking of the oil tanker, the Prestige, off the coast of Galicia in November 2002.

It was nevertheless in the field of foreign affairs where the PSOE was able to establish its credentials as a party in touch with public feeling, most notably with regard to the government's support for the US-led invasion of Iraq, a development which was opposed by the majority of the population. 
Rodríguez Zapatero and other prominent Socialist leaders attended massive demonstrations throughout Spain in the run-up to the war as opinion polls indicated that over 90 per cent of the Spanish population was opposed to Spanish participation in the conflict.

Despite the unpopularity of Aznar's policy on Iraq, the PP was able to hold its own at the municipal and autonomous community elections held in May 2003, with the PSOE gaining just 160,000 more votes than the governing party throughout Spain. The result suggested that, despite public dissatisfaction with the government's policy on Iraq, the PP remained on course to secure a further victory at the general election due in March 2004. Rodríguez Zapatero could nevertheless justifiably claim by the time of the election that he had not only engineered a clean break with the González era, but also consolidated his leadership on the basis of a unity within the party which had hitherto been notably absent. Furthermore, the PSOE had been able to offer a responsible opposition which had shown a willingness to reach agreement with the government on matters of national importance. The chief point of disagreement was on the question of the PP government's support for the war in Iraq. In its programme for the election, the PSOE described the conflict as 'an illegal war based on a mass of deliberate lies and falsehoods'. Spanish troops would only remain in Iraq if the occupation were placed under UN control (PSOE 2004: 23-4). If nothing else, this pledge lodged itself in the minds of the Spanish electorate as the election approached.

Much has been written on the particular circumstances in which the March 2004 general election took place. It is therefore unnecessary to cover similar ground (for more detailed coverage of the election, see Chari 2004; Closa 2004; Noya 2004; and Paramio 2004). Research indicates that the terrorist attacks did have a decisive effect on the general election held three days after the attacks (Michavila 2005: 32-3). Although the effect was small in percentage terms, it was sufficient to change the result. The effect of the attacks led to the mobilisation of 1,700,000 voters who felt impelled to vote on account of the bombings and the emotive aftermath.

Given the special circumstances in which the election took place, turnout was unusually high at just under 76 per cent. Yet, despite gaining over eleven million votes, more than at any time during its history, the PSOE, which won 164 parliamentary seats - sixteen more than the PP - was still twelve seats short of the 176-seat total necessary for an overall majority (see Table 5.1). Rodríguez Zapatero had ample reason to be satisfied with the result: he had won a general election at the first attempt, a feat which had hitherto only been achieved by Adolfo Suárez in 1977. The PP had a more unenviable record as the first party with an overall majority to lose a general election. 
Table 5.1 Spanish and general election results, 2004 and 2008

\begin{tabular}{lccccccc}
\hline & \multicolumn{2}{c}{2008 (turnout: $75.32 \%)$} & & \multicolumn{2}{c}{$2004(75.66 \%)$} \\
\cline { 2 - 5 } \cline { 7 - 8 } Party & Votes $(m)$ & $\%$ & Seats & & Votes $(m)$ & $\%$ & Seats \\
\hline PSOE & 11,064 & 43.64 & 169 & & 11,026 & 42.59 & 164 \\
PP & 10,169 & 40.11 & 153 & & 9,763 & 37.71 & 148 \\
CiU & 0.774 & 3.05 & 11 & & 0.835 & 3.23 & 10 \\
EAJ-PNV & 0.303 & 1.20 & 6 & & 0.420 & 1.63 & 7 \\
ERC & 0.296 & 1.17 & 3 & & 0.652 & 2.52 & 8 \\
IU & 0.963 & 3.80 & 2 & & 1,284 & 4.96 & 5 \\
BNG & 0.209 & 0.82 & 2 & & 0.208 & 0.81 & 2 \\
CC-PNC & 0.164 & 0.65 & 2 & & 0.235 & 0.91 & 3 \\
UPyD & 0.303 & 1.20 & 1 & & - & - & - \\
NA-BAI & 0.062 & 0.24 & 1 & & 0.061 & 0.24 & 1 \\
EA & 0.050 & 0.20 & - & & 0.080 & 0.31 & 1 \\
CHA & 0.037 & 0.15 & - & & 0.094 & 0.36 & 1 \\
\hline
\end{tabular}

Source: Spanish Interior Ministry (2008)

Key:

BNG = Galician National Bloc;

CC-PNC = Canary Islands Coalition;

$\mathrm{CHA}=$ Aragon Council;

$\mathrm{CiU}=$ Convergence and Union (Catalonia);

$\mathrm{EA}=$ Basque Solidarity;

EAJ-PNV = Basque Nationalist Party;

$\mathrm{ERC}=$ Catalan Republican Left;

$\mathrm{IU}=$ United Left;

NA-BAI = Yes Navarra;

$\mathrm{PP}=$ Popular Party;

PSOE = Spanish Socialist Workers' Party;

$\mathrm{UPyD}=$ Progress and Democracy Union

\section{Back in office: 2004-09}

For all the debate over the margin of manoeuvre still available to national governments in the field of economic policy, the position of Rodríguez Zapatero's PSOE government became clear during its first term in office. His government eschewed innovation in favour of an orthodox economic policy aimed at promoting economic growth and stability. Acceptance of the hegemony of neo-liberal policy precepts and the very buoyancy of the economic legacy bequeathed by the PP government discouraged any temptation to introduce fundamental changes in the field of economic policy. When the PP left office in 2004 it was able to boast that the average rate of economic growth during its period in office had been above 3 per cent, 
1.2 per cent above the EU average. Spain had the world's eighth largest economy, and had become the world's ninth largest investor abroad, as well as being the eighth largest recipient of foreign investment. Four-andhalf million jobs had been created, and the unemployment rate had more than halved to 11 per cent. Public debt had decreased from 68 per cent of GDP in 1996 to 50 per cent in 2004, while the public deficit, which totalled 6.6 per cent of GDP in 1995, had been returned to surplus by 2003 (PP 2004a: 11-12; 2004b: 6).

Continuity, rather than innovation, has therefore characterised the PSOE government's actions in the field of economic policy, and there has been relatively little difference between its policies and those of its predecessor. Indeed, it can be argued that this continuity has been key to the success of the Spanish economy over recent years. The fact that the Finance Minister in Felipe González's last government, Pedro Solbes, carries out the same duties under Rodríguez Zapatero is a further example of continuity in the area of economic policy.

Overall, the economy performed well during Rodríguez Zapatero's first term in office. GDP growth averaged 3.7 per cent, while the public debt was on course to be below 35 per cent of GDP in 2008, making it one of the lowest in the EU, behind just Luxembourg and the Republic of Ireland. Taxes on both businesses and individuals were reduced: corporation tax on small and medium-sized enterprises (SMEs) was cut from 30 per cent to 25 per cent in 2007 - the first reduction in twenty years - while 99.5 per cent of those paying income tax benefited from a reduction in 2007. While the average reduction was 6 per cent, those with an annual income below 18,000 euros obtained a reduction of up to 17 per cent in their contributions. The minimum pension was increased by 25 per cent, benefiting three million citizens, while the monthly minimum wage was due to rise from 460 euros to 600 euros in 2008, affecting 400,000 workers (PSOE 2006: 4-5; 2008: 7; Ministerio de la Presidencia 2007: 73-86). While the top rate of personal income tax was also reduced from 45 per cent to 43 per cent, it is clear that the effect of the PSOE government's fiscal policies was redistributive overall.

By the end of the PSOE's first term in office in 2008, the government had a case for arguing that Spain boasted one of the most buoyant and dynamic economies in Europe. Whereas the party's reputation for competence in the field of economic policy had suffered significantly during Felipe González's final years in office, no such problem existed under Rodríguez Zapatero.

Beyond economic policy, the PSOE has been able to display a significant degree of innovation with respect to other areas of government policy, particularly in the field of civil liberties. Concerned about their electability, social democratic parties in the late twentieth and early twenty-first 
century have increasingly sought a broader base in 'progressive' opinion, leading them to adopt a 'citizenship-focused' discourse, which indicates the degree to which social liberalism has influenced social democracy (Pierson 2001: 59). Rodríguez Zapatero's government has proved to be a prominent example of this shift, as it has sought to promote a form of 'citizens' socialism', aimed at broadening civil rights. As noted above, the influence of Philip Pettit is particularly apparent here. The development of this new, distinctive, set of policies had the advantage of differentiating Rodríguez Zapatero's PSOE from that of Felipe González, which, as we have seen, lost credibility due to the involvement of party figures in corruption cases during the PSOE's final years in office.

The first legislation which the Rodríguez Zapatero Government placed on the statute book in December 2004 was concerned with the issue of domestic violence, which the government viewed as being a flagrant violation of human rights, denying women their full rights as citizens. Expenditure on tackling domestic violence was to total over half a billion euros, divided between seven separate ministries, with measures including the provision of financial aid to victims and stiffer sentences for offenders.

Women occupied one-half of cabinet seats during the PSOE's first term in office, a proportion which was increased following the PSOE's general election victory in March 2008, as women were appointed to nine of the seventeen cabinet posts. María Teresa Fernández de la Vega was appointed First Deputy Prime Minister, the first time in Spanish history that a woman had occupied the post. Further initiatives included a law on equality (ley de igualdad), passed in March 2007. This legislation was considered necessary in order to ensure a more effective application of the right of equality before the law enshrined in Article 14 of the Constitution. The law stipulates that no gender will be able to account for less than 40 per cent of candidates on lists for elections to the Congress of Deputies, local councils, the European Parliament and the legislative bodies of Autonomous Communities.

Legislation was also passed in July 2005 which allowed marriage between persons of the same sex and gave lesbians and gays the right to adopt. The law on divorce was also liberalised in the same month, attracting considerable criticism from the Catholic Church, which had already opposed the government's plan to drop compulsory religion classes from the curriculum. The government's response to the Church was to stress the non-denominational character of the Spanish state as established in the 1978 Constitution. The government's actions were not, therefore, without political risk, although this did not prevent it from presenting its legislation as the latest manifestation of the social modernisation which the PSOE has historically sought to promote, alongside its efforts to achieve Spain's 
economic modernisation. Limiting the political or legal promotion of religion was argued to be in line with this objective.

Another important piece of social legislation concerned the provision of state assistance to those dependent on carers. The dependency law (ley de dependencia) passed in November 2006 guaranteed state assistance to elderly people and those suffering from severe disabilities, including mental illness. The government estimated that around 1,125,000 people would qualify for assistance under the terms of the law. Given that family members to some extent constitute a de facto branch of the welfare state in Spain, the offer of financial help was likely to prove popular. Home help, dedicated day and night centres and residential care would be provided to those qualifying for assistance. The measure meant that many who would otherwise have to leave their jobs in order to look after dependants would no longer have to do so. The government, which initially invested over 12 billion euros in the initiative, indicated that it would lead to the creation of 300,000 related jobs by 2015 .

In its editorial on 2 December 2006, the newspaper El País judged the initiative to be the most important piece of legislation passed by the government. Moreover, it was viewed as 'the greatest advance in the extension of social rights since public healthcare was universalised' (El País 2006: 16). For its part, the government described the measure as providing the welfare state with a 'fourth pillar', joining existing provision in health care, education and pensions. The proposal therefore constituted further proof of the PSOE's redistributive instincts.

The question of immigration proved to be more controversial, with the government receiving particular criticism for its decision to regularise, after a three-month registration period between February and May 2005 , the status of over 700,000 immigrants who had previously been working within the black economy. A report published by the Prime Minister's Financial Office in November 2006 examined the link between immigration and the Spanish economy during the period 1996-2006. Spain's immigrant population had quadrupled between 2000 and 2006 from just below one million to four million, with a clearly favourable effect on economic growth: almost one-half of GDP growth between 2002 and 2006 was due to the effects of immigration. Moreover, the report found that the influx of immigrants would decrease the tax burden on future generations of Spaniards, while also contributing towards the sustainability of the welfare state (Oficina Económica del Presidente 2006: ii-iii).

Important government legislation beyond the social sphere included the law concerning the recovery of historic memory (ley para la recuperación de la memoria histórica), which was passed in 2007. The legislation aimed to 
honour the memory of those who had suffered repression at the hands of the dictatorship both during and after the Civil War. Once again, the law was controversial, in that, hitherto, there had existed throughout the transition to democracy and beyond a so-called 'agreement to forget' (pacto de olvido). This consisted of a tacit agreement across the political spectrum not to engage in any claims concerning the violation of human rights under the Franco regime (Aguilar 1996, 2002). There had been no official parliamentary condemnation of Franco's coup, nor had there been any tribute to Franco's victims until Rodríguez Zapatero became prime minister. It was thought that any attempt to revisit the past, much less seek to call people to account for their actions during the Civil War and Francoist dictatorship, would only serve to reopen old wounds, if not derail democracy itself. The law also proposed the removal of Francoist symbols from public buildings. The government dedicated 69 million euros to the initiative, 20 million of which would go to victims in the form of pensions and allowances. Although the government argued that the law would serve to improve the quality of Spanish democracy, opponents of the initiative, including the $\mathrm{PP}$, responded by accusing the government of acting prematurely, in that it had failed to ensure a consensus on the issue before acting.

Despite such criticisms, Rodríguez Zapatero's achievements as PSOE leader and prime minister were considerable. When he took over the leadership, the party was directionless, riven with disunity, and seemingly unfit for government. Yet Rodríguez Zapatero was capable of transforming the party in such a way that he was able to gain the confidence of the population and win two consecutive general elections. Once in office, his political courage enabled him to carry out a coherent set of progressive reforms which many in the previous generation of the party leadership had considered unrealisable. Having established for himself the reputation of being one of European social democracy's boldest leaders, he has shown that audacity need not be a hindrance to electoral success.

\section{Conclusion}

As Spain's dominant political party, the PSOE has been able to make political capital out of its long history without allowing itself to be a prisoner of its past. Practically rebuilt by Felipe González, the party was able to exploit a relatively extreme ideological stance based on a Marxist self-definition in order to establish dominance on the left, only to drop that tag when accusations of extremism jeopardised the path to office. Finding itself in office at a time when social democratic economic policy precepts based on Keynesianism appeared to have lost their effectiveness, the PSOE chose a pragmatic mix of policies, which, in time, contributed towards 
the consolidation of democracy and the transformation of the economy. If the PSOE had an ideology, it was an amalgam of 'Europeanisation/ modernisation' rather than socialism. The overarching aim was to distance Spain from its historical backwardness - socially, politically and economically - while adapting and equipping the country to secure and maintain a place among the European Union's leading group of countries. This is not to say that the PSOE government did not make a particular impact in areas traditionally considered to be of concern to social democratic parties. The establishment of a modern welfare state financed by a significantly increased tax burden and - crucially - by the economic boom of the latter half of the 1980s eloquently demonstrated the party's achievements in this area. As we have seen, a significant degree of redistribution was carried out by the PSOE under Felipe González. It has been calculated that in the decade 1980 to 1990 , the poorest 10 per cent of the population experienced a 17 per cent increase in income, while the richest 10 per cent witnessed a 5 per cent decrease (Tusell 1999: 316). What is also remarkable is that the González Government's acceptance of the need for a shift towards more redistribution in the wake of the 1988 general strike took place at a time when the majority of OECD and EU countries were pursuing diametrically opposed policies (Marín 2001: 425).

Despite these achievements, the PSOE displayed serious failings: intense concentration of power in the hands of the leadership, allied to an unrelenting emphasis on internal cohesion and stability, were essential elements in the party's hegemony during the 1980s, but proved to be unsuitable to addressing the challenges of a more competitive political environment in the following decade (Méndez-Lago 2006: 434-5). Moreover, the many instances of corruption which severely damaged the party's credibility in the early 1990s were, in part, symptomatic of the PSOE's organisational sclerosis and lack of internal democracy.

The gravity of the PSOE's situation only became fully apparent after the disastrous result obtained at the 2000 general election. The replacement of the González-era leaders by José Luis Rodríguez Zapatero and his generation offered the party a new start devoid of associations with a past whose achievements had been overshadowed by the phenomenon of corruption. For the first time in years, the PSOE began to make a favourable impression on a public dismayed by the PP government, which, once in command of an overall majority, had abandoned its previous moderation in favour of a more hard-line approach, most notably with respect to policy towards Iraq. With foreign policy featuring prominently in the particular circumstances of the 2004 election, the PSOE was able to achieve an unexpected victory.

Once back in office, the party adopted a strategy based on contrasting approaches in the economic and non-economic policy areas. While 
continuity and prudence have characterised economic policy, redistribution still features significantly in government policy. Those with the lowest incomes enjoyed the highest percentage decrease in their income tax contributions during the party's first term in office. Similarly, many lowincome families benefited from the dependency law. Beyond the economic sphere, the PSOE has put in place a number of innovative reforms in other policy areas, particularly with respect to civil liberties and gender rights. This combination has allowed the government under Rodríguez Zapatero to prioritise macroeconomic stability while at the same time distinguishing itself from its predecessor in government and - crucially - from previous PSOE governments, via a package of reforms which, it argues, has formed the basis of a distinctive progressive agenda founded on economic efficiency, social justice and individual freedoms. The PSOE's victory at the March 2008 general election - on a turnout which almost equalled that of the 2004 general election, which was considered to have been particularly high due to the effect of the terrorist attacks on Madrid - was just the latest indication of the PSOE's resilience, capacity for renewal, and unerring instinct for office.

\section{References}

Aguilar, P. (1996) Memoria y olvido de la Guerra Civil española (Madrid: Alianza).

Aguilar, P. (2002) 'Justicia, política y memoria: los legados del Franquismo en la transición española', in A. Barahona de Brito, P. Aguilar Fernández and C. González Enríquez (eds), Las políticas hacia el pasado (Madrid: Istmo).

Almunia, J. (1998) 'Entrevista a Joaquín Almunia’, Leviatán, 68. Almunia, J. (2002) Memorias políticas (Madrid: Punto de lectura).

Boix, C. (1996) Partidos políticos, crecimiento e igualdad. Estrategias económicas conservadoras y socialdemócratas en la economía mundial (Madrid: Alianza).

Boix, C. (1998) Political Parties, Growth and Equality (Cambridge: Cambridge University Press).

Burns Marañón, T. (1996) Conversaciones sobre el Socialismo (Barcelona: Plaza y Janés).

Calamai, M. and Garzia, A. (2006) Zapatero (Barcelona: Península).

Carvajal, P. and Martín Casas, J. (2005) Memoria Socialista (Madrid: Temas de Hoy)

Chari, R. (2004) 'The 2004 Spanish election: terrorism as a catalyst for change?', West European Politics, 27 (5).

Chislett, W. (1996) Spain 1996: the Central Hispano Handbook (Madrid: Banco Central Hispano).

Closa, C. (2004) 'From 9-11 to 3-11: Spain's role in the European Union', ARI No. 48/2004, Real Instituto Elcano de Estudios Internacionales y Estratégicos, Madrid.

El País (2006) editorial, 'La ley más importante’, 2 December. 
Heywood, P. (1994) 'Change within continuity: the Spanish Socialist Workers' Party'. Paper prepared for ECPR workshop, 'Different rates and types of change in political parties: from adaptation to transformation', Madrid.

Heywood, P. (1995) The Government and Politics of Spain (London: Macmillan).

Iglesias, M. A. (2005) La memoria recuperada (Tomo II) (Madrid: punto de lectura).

Juliá, S. (1997) Los socialistas en la Política española (Madrid: Taurus).

Kennedy, P. (2001) 'Spain's third way? The Spanish Socialist Party's utilization of European integration', Journal of Southern Europe and the Balkans, 3 (1).

Marín, J. M. (2001) 'La democracia consolidada 1982-2000’, in J. M. Marín, C. Molinero and P. Ysás (eds), Historia política: 1939-2000 (Madrid: Istmo).

Méndez-Lago, M. (2005) ‘The Socialist Party in government and in opposition’, in S. Balfour (ed.), The Politics of Contemporary Spain (London, Routledge).

Méndez-Lago, M. (2006) 'Turning the page: crisis and transformation of the Spanish Socialist Party', South European Society E Politics, 11 (3-4).

Michavila, N. (2005) 'Guerra, terrorismo y elecciones: incidencia electoral de los atentados islamistas en Madrid', Documento de Trabajo 13/2005, Real Instituto Elcano de Estudios Internacionales y Estratégicos, Madrid.

Ministerio de la Presidencia (2007) 2004-2008: Balance de Legislatura (Madrid: Secretaría de Estado de Comunicación).

Noya, J. (2004) 'Del 11-M al 14-M: estrategia yihadista, elecciones generales y opinión pública', ARI No. 562/2004, Real Instituto Elcano de Estudios Internacionales y Estratégicos, Madrid.

Oficina Económica del Presidente (2006) Inmigración y Economía Española: 19962006, Madrid.

Paramio, L. (2004) 'Un rayo en un día claro: el vuelco político en España', International Journal of Iberian Studies, 17 (3).

Partido Popular (2004a) Avanzamos Juntos. Programa de Gobierno del Partido Popular, Elecciones Generales de 2004 (Madrid: PP).

Partido Popular (2004b) Balance 8 Años de Gobierno (Madrid: PP).

Partido Socialista Obrero Español (2000) Resoluciones del 35 Congreso (Madrid: PSOE).

Partido Socialista Obrero Español (2004) Merecemos una España mejor. Programa electoral: Elecciones Generales 2004 (Madrid: PSOE).

Partido Socialista Obrero Español (2006) Intervención del Secretario General en el Comité Federal, 18 de noviembre de 2006 (Madrid: PSOE).

Partido Socialista Obrero Español (2008) Motivos para creer: Programa Electoral Elecciones Generales 2008 (Madrid: PSOE).

Petras, J. (1993) 'Spanish socialism: the politics of neoliberalism', in J. Kurth and J. Petras (eds), Mediterranean Paradoxes (Oxford: Berg).

Pettit, P. (1997) Republicanism: a Theory of Freedom and Government (Oxford: Oxford University Press).

Pettit, P. (2008) Examen a Zapatero (Madrid: Temas de Hoy).

Pierson, C. (2001) Hard Choices: Social Democracy in the Twenty-First Century (Cambridge: Polity). 
Rodríguez Cabrero, G. (2004) El Estado del bienestar en España: debates, desarrollo y retos (Madrid: Editorial Fundamentos).

Share, D. (1988) 'Spain: socialists as neo-liberals', Socialist Review, 18 (1).

Spanish Interior Ministry (2008) Resultados Electorales: 1997-2008. Available at: www.elecciones.mir.es/MIR/jsp/resultados/index.htm.

Tezanos, J. F. (1992) 'El papel social y político del PSOE en la España de los años ochenta. Una década de progreso y democracia', in A. Guerra and J. F. Tezanos (eds), La Década del Cambio. Diez Años de Gobierno Socialista 1982-1992 (Madrid: Sistema).

Tusell, J. (1999) Historia de España en el Siglo XX (Madrid: Taurus). 


\title{
A new Swedish model? Swedish social democracy at the crossroads
}

\author{
Dimitris Tsarouhas
}

\begin{abstract}
Introduction
Sweden has for a long time been viewed as a paradigmatic case for progressive politics. Swedish social democracy, to which the progressive character of such politics was attributed, could legitimately claim to have mastered the historic task of the revisionist Left: building a societal coalition around the goal of enhancing social welfare for all, while safeguarding the profitability of business and delivering economic growth. When economic crisis hit home in the early 1990s, accompanied by the loss of power to a resurgent centre-right, the Social Democratic Party (SAP) was left vulnerable to accusations of a neo-liberal transformation (Ryner 2002) and specific attacks on abandoning the goal of full employment or the wage politics of solidarity, earlier practised by the social democratic trade union confederation known as the LO. Meanwhile, the Swedish model of industrial relations premised upon social partner autonomy, industrial peace and high-level coordination between the LO and employers (SAF) had given way to wage-bargaining decentralisation, the withdrawal of the social partners from state boards and agencies and growing divisions within the labour movement. The ensuing crisis was therefore not merely about the electoral prospects of the SAP. It actually touched upon the fundamental premises upon which the Social Democrats had built their welfare coalition, thus jeopardising the prospects for recovery once the SAP was re-elected.

This chapter examines the evolution of the Swedish model in conjunction with social democratic reformism and the party's relations to the union movement. The starting point of the analysis is the organisational and institutional bond between the SAP and the LO that flourished during the golden age of welfare capitalism and was severely tested in the 1980s. The main argument of the chapter is twofold. First, I show how the collapse of the old Swedish model has not led to the disempowerment of the trade union
\end{abstract}


movement. A new pattern of policy harmonisation has emerged following the signing of the Industrial Agreement (IA) in 1998. This could now be used as a catalyst from which a new Swedish model, befitting the globalised and Europeanised reality of Swedish policy-making, could potentially emerge. Second, and equally importantly, show that powerful challenges to the continued relevance of the labour movement in Swedish policy-making are currently in operation. Internally, the centre-right coalition government's labour and trade union laws diminish the power of organised labour. Externally, a recent ruling by the European Court of Justice may have longterm implications for the viability of the Swedish model.

The chapter begins with a brief discussion of the collapse of the old Swedish model, before examining the Third Way of the 1980s. The next part goes on to present the empirical evidence in support of the emergence of a new Swedish model, and underlines the importance of the SAP-LO partnership in allowing the union movement to play an influential role in the labour market. The chapter then explains the internal and external challenges for the labour movement, and the conclusion summarises the main argument, before offering some preliminary thoughts on the future of social democracy in Sweden.

\section{The collapse of the old model: causes and explanations}

By the early 1980s, the Swedish model was in crisis. Changes in the labour market, the reorganisation of production and the failure of the wage-earner funds meant that the ability of the labour movement to secure welfare in return for growth was in doubt. The crisis also tested the unity of the labour movement, pitting party against unions on a number of occasions.

\section{New labour market actors}

From the 1960s onwards, new actors sat at the negotiation table. The growth of the white-collar confederation, TCO, broke the previous LO monopoly in representing employees. A shift from blue-collar to service employment further strengthened the TCO position. From the 1950s to the 1980s, the percentage of workers employed in manufacturing industry dropped from around 40 per cent to only 20 per cent (Whyman and Burkitt 1993: 605). A consequence of the rise in white-collar professionals was the undermining of intra-union solidarity. Also, public sector employment increased sharply after the mid-1960s, and by the end of the 1980s the state employed almost one out of three workers. The increase in the influence of public sector employers and unions altered the distributional equilibrium and offered little incentive to private employers for continuing with centralised negotiations. 


\section{Employment legislation and the wage-earner funds}

The smooth functioning of the Swedish model was premised on the implicit acceptance of the labour movement of the veto power that business retained regarding economic development. For the Social Democrats, collaboration with business had always been a sine qua non for the pursuit of welfare politics. From the late 1960s, employee dissatisfaction with the workplace and ideological radicalism pushed the trade unions to the left. The LO embarked on an offensive which culminated in the wage-earner funds initiative, leaving it exposed to a counter-offensive by employers in the 1980s.

When the unions failed to gain the consent of employers on democratising working life, they resorted to legislation. The SAP introduced new laws to please the LO and demonstrate the party's socialist credentials. The Employment Security Act (Lagen om Anställningsskydd - LAS), the Work Environment Act and the Co-Determination Act (MBL) are the best examples of that drive of the 1970s. The committee instructed to look into the issue of capital increase and the democratisation of working life also submitted its report to the 1976 LO Congress. The report suggested that firms employing more than fifty employees should be required to issue new shares to an 'equalisation fund' corresponding to 20 per cent of their pre-tax profits. Trade union representatives would administer the fund; after twenty to thirty years, unions would own most of the profitable Swedish enterprises.

In 1983, and after successive committees had modified the original plan, the SAP government legislated on the issue. The watered-down law provided for five funds run with union representation. The payroll tax financing the funds was reduced to 0.2 per cent and their build-up period was limited to seven years. A 20 per cent levy on real profits was introduced and the law underlined the function of the funds as portfolio investors, with an obligation to show a minimum 3 per cent return on their investment. No single fund could own more than 8 per cent of a company's shares. By the time legislation was introduced, moreover, opposition had grown enormously, and in 1991 the centre-right government was able to abolish the funds entirely.

\section{Flexible specialisation}

Flexible specialisation also undermined intra-union solidarity, challenging the hold of the LO over its constituent unions. "The widespread application of numerically controlled, multipurpose machinery during the 1970s and 1980s led to a shift away from standardised mass production ...' (Iversen 1996: 406). Taylorist principles reached the limits of their effectiveness. They were replaced by a mode of production emphasising the 'responsible autonomy' of workers. 
The reorganisation of work was greeted by Swedish employers in the engineering sector as an opportunity to embrace flexible production techniques. However, the existence of the solidaristic wage policy practised by the LO since the 1950s meant that non-standard forms of payment were inhibited, posing a competitiveness risk resulting from the failure to attract high-skilled labour (Pontusson and Swenson 1996: 236). In a similar fashion to the engineering employers, engineering unions resented the fact that public sector unions were living off their productivity-based wage increases through the phenomenon of wage drift. Bound by the Confederation's solidaristic wage policy, skilled workers saw their relative pay position worsen compared to white-collar colleagues. Furthermore, the balance of power within the LO shifted in line with public sector expansion: in 1978, 'the traditional dominance of the metalworkers . . . was displaced by the largely female Municipal Workers' Union' (Callaghan 2000: 125). Under these conditions the process of decentralising collective bargaining gathered pace. The Engineering Employers' Organisation (Verkstadföreningen - VF) and its LO union counterpart Metall ceased to practise centralised bargaining in 1983, having agreed to wage increases higher than those negotiated centrally between the LO and SAF.

\section{The Third Way and the 'war of the roses': crisis contained}

The Social Democrats launched the 'Third Way' economic policy programme in 1981. The new approach called for a reappraisal of economic policy and the elimination of the current account deficit. To restore lost competitiveness, the economy had to transfer resources to the private sector (SAP 1981). The SAF was particularly pleased with the new approach of targeting inflation and removing the indexation of wages. However, the SAP continued to defend full employment and a strong welfare state (SAP 1985). At the same time, the LO was asked to accept lower budget deficits and a smaller public sector. The state in general and public spending in particular ceased to be seen as solutions (as they had been during the post-war boom) in public discourse and became instead the most frequently cited problems that needed to be addressed (J. Andersson 2006). The union-party clash that ensued included fierce disagreements over welfare reform and especially privatisation schemes. Public sector unions were particularly vocal, accusing the party of treachery and a disregard for members' interests. ${ }^{1}$ The austerity measures introduced after the 1988 election (including the reduction of sick pay rates from 90 per cent to 65 per cent for the first three days and to 80 per cent from day four up to ninety days' absence), meant that the SAP fell to 37.7 per cent in the polls in 1991, and a new government headed by the Conservative Prime 
Minister Carl Bildt was sworn in. By that time, the SAP had declared low inflation to be the party's main priority, instead of full employment. In 1990, the SAF appointed a new chairman, Ulf Laurin, distinguished for his antipathy towards the Saltsjöbaden 'spirit'. Upon taking the decision to dismantle the SAF Negotiations Unit in February 1990, Laurin proudly proclaimed the death of the Swedish model. Following the self-imposed termination of peak-level negotiations and having achieved a significant amount of policy change during the 1980s, the SAF called for coordinated decentralisation and plant-level wage bargaining.

In the 1994 pre-election campaign, the SAP vowed to ease off the pressure on state finances and reduce the high deficit through budget cuts and tax increases. This led to sceptical reactions by domestic and international capital, which enjoyed a high degree of independence from government policies, and did not feel bound to the old compromise with social democracy. The SAP proposed a four-year crisis package combining a 5 per cent 'recovery tax' on high earners, a rise in national insurance contributions and the lifting of municipal tax ceilings with cuts in foreign aid, refugee assistance, student grants and child pension and invalidity payments (Burkitt and Whyman 1995: 32). In a direct appeal to sceptical LO members, the SAP vowed to increase employment by 100,000 in four years.

The decision by Finance Minister and later Prime Minister (19962006) Göran Persson to cap public expenditure did not go down well with the LO and SAP supporters. The changes in the social insurance and labour market rules instigated by the Bildt government continued, and many of its social insurance reforms remained intact (Swank 2002: 139). Disgruntled voters switched to the Vänsterpariet (which may be literally translated from Swedish as the Left Party), which in 1998 became the third largest party in Parliament. In that year's election, 20 per cent of LO members voted for the Left Party, compared to a mere 4 per cent in 1991 (Möller 1999: 266). SAP ended up gathering a mere 36.5 per cent of the vote, a new low.

During the next two parliamentary terms (1998-2002, 2002-06) the SAP sought to consolidate its position at the heart of the Swedish political system and regain the trust of voters. It sought to do so by curbing unemployment and protecting the universal character of the welfare state through the initiation of measures such as a cap on childcare fees. Accelerating economic growth at the end of the 1990s meant that unemployment fell to about 4 per cent in 2001 (OECD 2001: 3). Having campaigned on the basis of preserving and extending the welfare state, the Social Democrats increased their vote share to 39.9 per cent in 2002 and remained in power with the support of the Left and the Green Party. 


\section{The Industrial Agreement and beyond: a new Swedish model?}

The collapse of the old Swedish model had three major consequences. First, it removed the foundations of the 'welfare-in-return-for-growth' exchange between social democracy and business. Second, it permitted the articulation of a coherent business doctrine that mounted a massive challenge to the old consensus. Finally, it threw Swedish social democracy into a long period of crisis and self-doubt. The collapse of the model questioned the ability of the SAP to steer the system in favour of the 'many' in conditions of rising complexity, and it led to the deterioration of relations between the party and the LO. It also threatened to remove the hold of Swedish social democracy over policy ideas by removing the basic principles of its function, and by dealing a fatal blow to its ability to deliver economic dynamism with social cohesion. Developments after the mid-1990s and especially since the early 2000s, however, signify that far from being just another case of 'organized decentralization' (Traxler 1995), the Swedish labour market is characterised by a high degree of continuity with the past. Combined with a discernible improvement in the party-union relationship, the prospects for a new Swedish model offer the chance for the articulation of a new progressive image of the good society.

\section{The role of the social partners}

The SAF's organisational restructuring in the 1990s did not transform its role. The principle of negotiation established in Saltsjöbaden was left untouched during the restructuring process. Collective agreements have continued to inform the logic of labour market action for employers. The SAF also retained the principle of insurance; additionally, the imposition of heavy fines on companies that did not abide by SAF directives continued through the mid-1990s (Pestoff 1995: 173). The exceptionally strong sense of collective action espoused by Swedish business remained intact. The amalgamation of the SAF and SIF to create the Confederation of Swedish Enterprise (Svenskt Näringsliv - SN) in 2001 hardly changed that collectivism:

In the statutes of the Confederation of Swedish Enterprise it says that the Board of Directors decides on the goals of the bargaining round for all member associations ... the level of compensation paid to members hit by industrial action is based on the way [they] have executed their obligations to inform and consult during negotiations. ${ }^{2}$

The best proof of SN centralisation came in 2007. When the Swedish Trade Federation (Svensk Handel) yielded to demands by its union counterpart for high wage increases, SN threatened action against its member and called 
for intervention by the Mediation Institute to resolve this particular intraemployer conflict. Faced with the prospect of a costly and embarrassing conflict, SN gave in (Dagens Nyheter 14 April 2007).

On the part of the LO, the initial response of the Confederation to the shift of the 1990s was to support measured change. An appreciation of individualised and flexible wage systems, it was argued, would encourage workers to update their skills and achieve professional advancement (LO 1991). At the same time, the LO was prepared to accept the need for change regarding the role of its member unions, who would now be called on to assume greater responsibilities. An LO report of 1992 sketched out what was later to become the LO's prime function: coordinating the wage demands of unions and setting the framework of their negotiations. The report also called for an emphasis on reducing the pay differentials between men and women (Johansson and Magnusson 1998: 339), a policy that became a prominent part of LO thinking by the late 1990s. However, not all unions endorsed the 1993 proposal for the LO to retain a coordinating role in wage bargaining. Metall suggested curbing public sector calls for compensation, but unions such as Kommunal did not necessarily share this view. 'The role of the LO has been questioned by all sections of society, even from our own members. They were not sure whether the LO should have a role in wage bargaining ... it was really an open question'. ${ }^{3}$

While deciding to retain the principle of solidarity in a way acceptable to all members, the LO emphasised that economic growth would increase the living standards of all members, and that economic policy should keep inflation at an average European level. By the time of its 24th congress in 2000, the LO asserted that 'the new politics of solidarity' had four functions: (a) full employment; (b) real wage increases for all and slightly higher rises for the lowest paid; (c) just distribution; and (d) work development (LO 2000: 744).

\section{Wage bargaining: from decentralisation to coordination}

The shift to a lower level of bargaining has not been accompanied by the realisation of all the changes envisaged by employers. Increased crossoccupational collaboration became part of labour's strategy to prevent the development of enterprise unionism and retain industry-wide bargaining (Thelen 1993: 47).

The Industrial Agreement (IA) of 1998 sprang out of the need for closer collaboration between blue- and white-collar workers in the face of industrial change, and the recognition that the export sector should remain the pace-setter in wage development. Trade unions in manufacturing industry led by Metall inspired a broad dialogue encompassing employer 
organisations and trade unions to provide a framework for collective bargaining. In March 1997, the IA was signed by twelve employer organisations and seven trade unions. The reinvigoration of a spirit of collaboration between employers and unions is mediated by the realisation that enhanced competition and the Europeanisation of Sweden's labour market poses new challenges regarding competitiveness and the maintenance of high pay and working standards.

The Agreement set out to offer a new mode of regulating the labour market by concentrating on the need to avoid industrial action for as long as possible, promoting industrial development and enhancing profitability to secure sound wage development. The labour market partners agreed on the establishment of an industrial committee, which would have the power to intervene in the negotiations at an early stage. The IA was tested in the bargaining round of 1998 for the first time and turned out to be a success. All timetables were kept, industrial action was not contemplated and the wage levels agreed became the norm for the rest of the labour market (Elvander 2002: 130). What is more, the Industrial Agreement reconfirmed the 'spirit of Saltsjöbaden', in that unions and employers agreed on the need to avoid state interference in collective bargaining. With regard to the level of bargaining, decentralisation and local negotiations became the norm in a series of collective agreements. Local partners assumed responsibility for the level and distribution of wages. However, the prerogative of employers to set wage levels according to their preferences was curbed due to 'cut-off' provisions that specified wage increases as well as, in many cases, the minimum wage increase for individual workers.

Following a series of earlier failures to coordinate its affiliated unions, the LO has met with considerable success since the early 2000s. Before the start of the 2001 bargaining round, it made a series of suggestions to its member unions regarding minimum pay increases and the above-average wage increases that should be awarded to the lowest paid (LO 2001: 4-5). Despite the special arrangement that LO unions have with white-collar and professional engineering unions, all LO unions were bound by the accord and agreed to its recommendations. The same procedure was followed in 2004. The role of the LO was now more pronounced, as individual unions did not make amendments to the text agreed at confederal level. The chief coordinator of the $\mathrm{LO}$ for the 2004 round described the latter as 'the most centralised [round] I have been through'. ${ }^{4}$

Finally, the 2007 bargaining round was characterised by the LO's decision to secure higher wage increases for its female members, most of whom are organised in Kommunal. The gender-neutral attempts to implement such a policy had met with little success in the past, and about 90 per cent 
of female LO members belong to the lowest-pay scale. Although Metall put up a fight against increases targeted at women, it succumbed to collective pressure and abided by the coordination demand. The export-oriented sector functioned once again as a pace-setter, and both Kommunal and Metall concluded collective agreements that can boost the wages for the lowest paid, thus confirming the salience of LO coordination (Dagens Arbete, 19 March 2007). What is more, the Kommunal agreement with employers in the municipal sector now includes an equality pot that can potentially reduce wage differentials in a way that has not been achieved since the 1990s. On the other hand, the 2007 bargaining round also revealed the first serious cracks in the IA structure, as Handels and Kommunal secured wage increases above the levels prescribed by the IA agreement. Still, successful coordination over the last few years has led the LO to request authorisation for a formal coordination at its 2008 congress.

In the early twenty first century, the social partners retain a key role not only in regulating the labour market, but also in complementing statefinanced welfare. The LO and Svenskt Näringsliv came together in two supplementary agreements, on sick pay (Avtalsgruppsjukförsäkring-AGS) and an insurance scheme against job loss (Avgångsbidragsförsäkring-AGB). The two sides have created a co-owned company, AFA, responsible for insurance against death, work injuries, illness and redundancy. The company has calculated that about three million people are insured against at least one of these risks with AFA. In addition, the LO and Svenskt Näringsliv have created a safety foundation (Trygghetsfonden - TSL) to support employees who have recently been made redundant. Statistics show that 85 per cent of those benefiting from TSL funds had found a new job in 2006 (TCO Tidningen, 8 March 2007). Finally, a revised pension agreement between the LO and SN was signed in 2007 equalising pension conditions for LO members with those of white-collar employees (TT, 16 April 2007).

\section{Institutional resources}

The highly uncertain 1990s have been replaced by a challenging but more predictable framework of operation for the Swedish labour movement. A key factor behind the continued ability of organised labour to influence the public policy debate is the high union density rate, which stood at 77 per cent in 2006. The growing influx of migrant labour in the 1990s could pose a serious challenge to unionisation rates, assuming that the 'union culture' of Sweden is much weaker in other parts of the world and particularly outside Western Europe. Nonetheless, a 2004 LO report showed that women originating from non-European countries had a rate of unionisation as high as 74 per cent, and most of them belonged to a union affiliated to LO (LO 2004). 
The centralisation of industrial relations in the early twentieth century meant that firm-by-firm struggles were largely avoided and 'extensive union access to workplaces helped maintain rank-and-file contact and organize workplace bargaining' (Kjellberg 1998: 617). The ability of both unions and employers' organisations to centralise and gain access to places of work is not a fortunate coincidence. It is derived from the historical character of the Swedish state and the concomitant emergence of industrialisation and democratisation that facilitated the growth of strong unions as part and parcel of a democratising polity, with a strong labour movement consolidating its strength in the absence of a coherent conservative counter-force. Added to that is the Ghent-type unemployment insurance funds, offering trade unions control of the funds' administration. Although successive reforms of the funds have rendered union powers weaker, organised labour continues to exert a heavy influence on the running of the funds. The 1930s initiative by the SAP to create a Ghent-type system has rendered very practical, long-term results in terms of trade union strength.

Finally, relations between the SAP and the LO have improved steadily after their low point of the 1990s and are seen as highly cooperative and effective by both sides. ${ }^{5}$ The Europeanisation of Swedish politics, and the influence of the common stance of the SAP and LO on EU issues, has played an important role in this process. The power and influence of the trade unions remains decisive in the process of decision-making for the Social Democrats. To give but one example, in 2004 the government agreed to reform LAS legislation after union pressure. The new piece of legislation would prioritise fixed-term workers in moving to open-ended employment contracts, and offer them the opportunity to be reclassified as open-ended employees under favourable conditions. It is through such measures that the earlier public sector union grievances have diminished, and LO financial and organisational resources are put at the disposal of the party machinery prior to electoral contests.

\section{Contemporary challenges: the 2006 election and the Europe factor}

\section{The 'Alliance for Sweden'}

Judging by the historical record, the chances of the Social Democrats winning yet another election in 2006 were very high indeed. Every time they had lost power before, the economy was in trouble and the party's ability to guarantee prosperity was in serious doubt. In 2006, however, the economy was booming and public finances recorded a healthy 3 per cent surplus (Aylott and Bolin 2007: 621). Not much seemed to be going wrong.

What did go wrong, however, was the impression or (according to some) 
the fact that Sweden suffered from 'jobless growth'. The subject of continuous controversy well before the election campaign, the rate of unemployment was making headlines for months, as the government claimed much lower rates of unemployment than the ones reported by international organisations. The opposition was quick to accuse the government of misleading the public and eventually managed to persuade voters that the SAP was unable to offer solutions to the problem. In combination with a slow trickle of minor scandals which dented the reliability of key ministers and the objectivity of civil servants, the belated recognition by the SAP that employment constituted the main campaign issue was unable to avert defeat, handing over power to a resurgent centre-right coalition, the 'Alliance for Sweden'.

The new government was soon marred by controversy, and the initial honeymoon usually afforded by voters to incumbent governments vanished. The government's main problem has been its welfare reform programme, not least its changes in the unemployment insurance scheme. Adopting a workfare approach to welfare and claiming to defend the welfare state, the government maintains that its reforms merely aim at making existing welfare structures work better. The one-time neo-liberal Moderate Party denies that it intends to reform labour law or hamper the Swedish model. There are important reasons to doubt the sincerity of such claims, at least regarding their consequences for the trade unions.

The government introduced a series of amendments to the unemployment insurance scheme with regard to eligibility, levels of compensation and the financing of insurance. Membership fees are set to increase to a maximum of SEK 300 for employed people, and insurance funds will have to bear one-third of the overall costs to support 'their' unemployed members. The eligibility threshold to qualify for the benefit will increase from 70 to 80 hours per month for six months out of a total of twelve months. Finally, compensation levels will progressively decrease from 80 per cent of gross earnings for the first 200 days to 70 per cent after 300 days and to a maximum of 65 per cent thereafter, upon participation in a new job and development guarantee scheme.

The consequences of these changes are very significant. Apart from the lower 'take-home' compensation, the change in financing of the system is likely to undermine intra-fund solidarity by pitting funds with lower unemployment levels against those with higher levels. State financing of the funds will go down from about 90 per cent in 2005 to 56 per cent after the changes are introduced. The LO has also calculated that after-tax earnings from unemployment insurance after 300 days of unemployment will reach the (much lower) levels of social assistance in the coming years (Dagens Nyheter, 17 November 2006). The question then becomes whether 
the intention of the government is to boost employment levels by indirectly forcing the unemployed to accept lower wage standards. The LO is more likely to be hit by such measures, as unemployment among LO members is higher than for other occupational categories.

As the unions had predicted, a massive exodus from the unemployment insurance system has followed the introduction of the reforms. About one in ten members have left the system during 2007 (Dagens Nyheter, 13 December 2007). Not least due to decreasing revenues following lower participation, the government's most recent response has been to propose making unemployment insurance membership obligatory. Unions and employers, for very different reasons, agree that the current system of optional membership should be preserved (Svenska Dagbladet, 22 October 2007).

At the end of 2007, the government announced a new set of welfare proposals. The envisaged reform increases unemployment insurance qualifying days from two to seven, limits receipt of unemployment benefit to seventy-five days for part-timers and to eight months for the unemployed, decreases sickness benefits and abolishes the SAP reform which would have obliged employers to co-finance sick leave for full-time employees (EIROnline, 2007). The SAP reform to ease moving from fixed-term to permanent employment has also been hindered by legislation facilitating fixed-term employment. Finally, the government's proclamation on the desirability of maintaining the Swedish model has been subjected to intense criticism from the SAP, LO and TCO following its proposals to block agreements by the social partners guaranteeing higher replacement rates for long-term sick employees compared to the state benefit. Since such agreements are reached through collective agreements, SN has also come out against such a reform (Dagens Nyheter, 22 December 2007).

Although a declining trend in union membership has been observed over a number of years, this decline was gradual and the organisation rate of Swedish unions remained very high. Recent data paints a picture of dramatic union membership decline, parallel to the mass exodus from the unemployment insurance system. As of December 2007, the unionisation rate stood at 72 per cent, a 5 per cent decline in a year, which means that the density rate is now at 1970 s levels. Although rising employment levels provide a plausible explanation, the centre-right's decision to abolish the tax-deductible status of union membership did little to boost union membership.

The centre-right government's workfare approach seriously affects the viability of the Swedish model. The decline in unionisation, if it continues, means that Sweden's unions will lose their main weapon of legitimacy. A union movement that ceases to be mass-organised will have less of an 
impact on the labour market, and will be less likely to steer employers towards mutually acceptable outcomes. Weaker unions will have less of an impact on elections, ceasing to mobilise workers in favour of the SAP. In turn, the Social Democrats' dependence on the unions will lessen, and this is likely to translate into yet more 'centrist' positions, disregarding the agenda of the labour movement. In other words, the consequences of the 2006 elections could have a long-lasting negative effect on Swedish social democracy.

\section{The Vaxholm conflict}

In December 2007, the European Court of Justice (ECJ) ruled that a blockade by trade unions led by the Construction Workers Union Byggnads, an LO member, against the Latvian company Laval un Partneri employing Latvian workers in a construction site in the city of Vaxholm, was unlawful. The ECJ judged that the blockade, in which other unions had also participated following unsuccessful negotiations to sign a collective agreement, had violated the EU principle of freedom to provide services and could not be justified on grounds of the public interest (EU Observer, 18 December 2007). Although the Court did not rule against the principle of collective action to avert social dumping, it asserted that a blockade of an unspecified duration in the absence of clearly set provisions was disproportionate. Prior to the final ruling, the issue had become intensely politicised. The dispute dates back to 2004, when Byggnads took action against Laval, and was strongly supported by both the SAP Government and LO. Svenskt Näringsliv had come under pressure from the labour movement when it was revealed that it had sought to avert Laval's eventual bankruptcy by offering financial assistance.

What is fundamentally at stake here concerns the Swedish system of collective bargaining and the application of EU law. Under the EC Directive on the foreign posting of workers adopted in 1996, employees posted abroad enjoy minimum standards of protection as laid out by the host state, either through legislation or collective agreement. At the time this appeared to be a confirmation of the Swedish model, verifying the legitimacy of the collective agreement system. However, it has been argued that the Directive's Swedish transposition in 1999 clashes with the EU principle of cross-border service provision (Woolfson and Sommers 2006: 59) and may not be applicable to EU firms. Laval had used the EC Directive in an earlier phase of the conflict, claiming that it was not mandatory to pay a minimum wage to its employees as Swedish legislation does not stipulate such levels, nor are they to be found in collective agreements.

The ECJ ruling has provoked a heated debate over the future of the Swedish model. Interestingly, both unions and employers have called for 
legislative action. While SN calls for limits to be placed on sympathy strike action, the LO has requested the amendment of the Posting of Workers Act to establish a level playing field for Swedish and foreign firms. Prior to the ECJ ruling, the LO and SN had sought to limit the disturbances caused by a possible 'Vaxholm effect' by signing an agreement 'recommended' to their members. According to that agreement, LO and SN members would adjust their collective agreements so that foreign companies temporarily joining an employer organisation of $\mathrm{SN}$ would be subject to legislation agreed between the social partners.

The challenges posed to the Swedish model following the ECJ ruling are numerous. To start with, the Vaxholm conflict highlights the frictions caused when a law-based juridical paradigm, as represented by the ECJ, conflicts with the collective agreements system reliant on encompassing unions and employers. If the government declines to amend the Posting of Workers Act, different companies will be subject to different legislation in the Swedish labour market, as Swedish legislation does not foresee the applicability of collective agreements beyond the sectors involved. This could, in turn, lead to higher levels of industrial action and productivity losses harming the Swedish economy. Second, the post-Vaxholm reality could mean higher wage differentials among but also between occupational categories, cancelling out the LO's recent advances. The welfare system would have to sustain higher demand, at a time when tax cuts for capital and wealth have been enacted by the centre-right government. Finally, the ECJ ruling offers a competitive advantage to employers prior to the commencement of negotiations on renewing the Saltsjöbaden agreement. The SN, LO and PTK will start negotiations on a new basic agreement that would take into account rapid changes in the labour market through Europeanisation and globalisation. Though their agenda is different, the two sides will seek to work out a compromise and confirm the sustainability of the Swedish model in the twenty-first century. An attempt to carve out a similar agreement previously ended in failure, but heightened levels of cooperation between the two sides offer grounds for more optimism this time round.

\section{Conclusion}

For the Swedish Social Democrats, the crisis of the 1990s was not merely an economic one. It was accompanied by the collapse of the old Swedish model and it questioned the viability of the progressive coalition centred on the party-union link. By the end of the 1990s, however, and due to the durability of the institutional resources at the disposal of the labour movement, combined with some shrewd policy moves on the part of the SAP, things 
improved. The party-union relationship, vital to maintain a comprehensive welfare regime and guarantee high-wage and work conditions, has picked up markedly, while the broad sketches of a new Swedish model have been developing since the signing of the Industrial Agreement. On the other hand, internal and external difficulties remain, and their consequences, if left unchecked, could be devastating in the long run.

Following the 2006 election defeat, Mona Sahlin became the first female SAP leader. Tainted by her role in the welfare cuts of the early 1990s as Labour Minister, Sahlin has made a triumphant return after she lost the first chance to lead the party in the mid-1990s due to a financial scandal. During 2007, the SAP has kept a low profile and has been largely absent from the political debate. The government's woes have helped the opposition parties to establish a commanding lead in the polls, and the SAP currently polls between 40 and 45 per cent of the vote. During 2007, the SAP has been clear in its condemnation of government policy, and Sahlin cowrote an article with the LO president promising to undo financial changes in unemployment insurance (Dagens Nyheter, 30 April 2007). On the other hand, the party is seeking to distance itself from the 'dependency culture' it allegedly cultivated and is likely to maintain the new, stricter rules on eligibility, along with a 'tougher' approach to school discipline. The SAP has joined forces with the Greens and the Left Party in attacking the government, while making common cause on issues such as climate change and civil rights. The departure of Persson has made collaboration with the junior opposition parties easier. At the same time, the Greens and the Left Party continue to maintain an intransigent anti-EU position that the SAP is unlikely to tolerate in a possible coalition government. What is more, the party leadership is closer to the Greens, but the rank and file would prioritise collaboration with the Left Party instead.

Swedish social democracy has some time until the next election to form a progressive party programme that clearly distinguishes it from the Moderates, and outlines the welfare and labour market changes necessary to maintain a competitive economy and a just society. This chapter has sought to emphasise that working with the unions remains the party's most valuable option. At a time of uncertainty and confusion, the Swedish labour movement cannot afford to fail in its mission. There is a good chance that it will not.

\section{Notes}

1 Interview with the Kommunal ombudsman, 16 September 2004.

2 Interview with the chief negotiator of the Svenskt Näringsliv in the European Federation of Enterprises UNICE, 18 August 2004. 
3 Interview with the LO public policy director, 1 September 2004.

4 Interview with the LO chief coordinator, Stockholm, 2 September 2004.

5 Interview with the ombudsman for SAP-LO relations, 24 September 2004.

\section{References}

Andersson, B. (2007) 'Rekordmånga flyr facket', Dagens Nyheter, 13 December.

Andersson, D. (2006) 'Arbetslöshetsförsäkringen omvandlas till socialbidrag', Dagens Nyheter, 17 November.

Andersson, J. (2006) 'Growth and security: Swedish reformism in the post-war period', in J. Callaghan and I. Favretto, Transitions in Social Democracy: Cultural and Ideological Problems of the Golden Age (Manchester: Manchester University Press).

Aylott, N. and Bolin, N. (2007) 'Towards a two-party system? The Swedish parliamentary election of September 2006', West European Politics, 30 (3).

Bäckström, U. (2007) 'A-kassan behöver konkurrens', Svenska Dagbladet, 22 October.

Bergström, H. (2007) 'Handelns jubel', Dagens Nyheter, 14 April.

Burkitt, B. and Whyman, P. (1995) 'Lessons from Sweden: full employment and the evolution of Keynesian political economy', Renewal 3 (1).

Callaghan, J. (2000) The Retreat of Social Democracy (Manchester: Manchester University Press).

EIROnline (2007) 'Unions criticise proposal to cut unemployment and sickness benefits': www.eurofound.europa.eu/eiro/2007/10/articles/se0710029i.htm (accessed 21 November 2007).

Elvander, N. (2002) 'The labour market regimes in the Nordic countries: a comparative analysis', Scandinavian Political Studies, 25 (2).

EU Observer (2007) 'Swedish trade unions lose EU labour case, 18 December': http://euobserver.com/9/25359 (accessed 19 December 2007).

Forsman, E. (2007) 'Trygghetsavtal ger arbetslösa nytt jobb', TCO-Tidningen, 8 March.

Gatu, H. (2007) ‘Höjda lägstalöner byter trend', Dagens Arbete, 19 March.

Iversen, T. (1996) 'Power, flexibility, and the breakdown of centralised wage bargaining: Denmark and Sweden in comparative perspective', Comparative Politics, 28 (4).

Johansson, A. L. and Magnusson, L. (1998) LO andra halvseklet. Fackföreningelsen och samhället (Uddevala: Atlas).

Kjellberg, A. (1998) 'Sweden: restoring the model?', in A. Ferner and R. Hyman (eds), Changing Industrial Relations in Europe (Oxford: Blackwell).

LO (1991) Rättvisa i vågskålen (Stockholm: LO).

LO (2000) Landsorganisationens 24:e ordinarie kongress 2-6 September 2000 (Stockholm: LO).

LO (2001) Rekommendation till förbunden med gemensamma krav inför Avtal 2001 (Stockholm: LO).

LO (2004) 'Rate of trade union organisation in Sweden': www.lo.se/home/lo/ home.nsf/unidView. 
Möller, T. (1999) 'The Swedish election 1998: a protest vote and the birth of a new political landscape', Scandinavian Political Studies, 22(3).

OECD (2001) Economic Survey Sweden (Paris: OECD).

Pestoff, V. A. (1995) 'Towards a new Swedish model of collective bargaining and politics', in C. Crouch and F. Traxler (eds), Organised Industrial Relations in Europe: What Future? (Aldershot: Averbury).

Pontusson, J. (1995) 'From comparative public policy to political economy: putting political institutions in their place and taking interests seriously', Comparative Political Studies, 28 (1).

Pontusson, J. and Swenson, P. (1996) 'Labor markets, production strategies, and wage bargaining institutions: the Swedish employer offensive in comparative perspective', Comparative Political Studies, 29 (2).

Ryner, M. J. (2002) Capitalist Restructuring, Globalisation and the Third Way: Lessons from the Swedish Model (London: Routledge).

Sahlin, M. and Lundby-Wedin, W. (2007) 'A-kassan ska återstellas till 80 procent av lönen', Dagens Nyheter, 30 April.

SAP (1981) Framtid för Sverige (Stockholm).

SAP (1985) Partiprogram (Stockholm).

Swank, D. (2002) Global Capital, Political Institutions and Policy Change in Developed Welfare States (Cambridge: Cambridge University Press).

Thelen, K. (1993) 'West European Labor in transition: Sweden and Germany compared', World Politics, 46 (1).

Tidningarnas Telegrambyrå (2007) Pensionsavtal för arbetare klart, 16 April.

Tidningarnas Telegrambyrå and Rönnqvist, A. (2007) Hård kritik mot försäkringsförslag, 22 December.

Traxler, F. (1995) 'Farewell to labour market associations? Organized versus disorganized decentralization as a map for industrial relations', in C. Crouch and F. Traxler (eds), Organized Industrial Relations in Europe: What Future? (Aldershot: Avebury).

Whyman, P. and Burkitt, B. (1993) 'The role of Swedish employers in restructuring pay bargaining and the labour process', Work, Employment and Society, 7 (4).

Woolfson, C. and Sommers, J. (2006) 'Labour mobility in construction: European implications of the Laval un Partneri dispute with Swedish labour', European Journal of Industrial Relations, 12 (1). 


\title{
The modernisation of German social democracy: towards a third way and back?
}

\author{
Hartwig Pautz
}

The German Social Democratic Party (SPD) has undergone a number of revisions since its birth in the nineteenth century. This chapter will explore the latest debate about what the SPD stands for. As a programme party, the debate about long-term objectives, values and ideological principles has been of particular importance to party members, its leaders and the public. Hence the focus of this chapter: it will document and analyse the programmatic discourse of the SPD between the adoption of the 1989 Berlin Programme and the 2007 Hamburg Programme. The analysis will centre on whether and how the meaning of social justice - together with freedom and solidarity at the core of the SPD's values - has changed and how this change is reflected in the SPD's concept of the welfare state and its labour market policies.

\section{The Third Way: revisionism in the $1990 \mathrm{~s}$}

The Third Way debate emerged as a collaborative effort of academics, thinktank experts, and politicians in the UK from where it influenced mainly Western European parties of the centre-left. It constituted a neo-revisionist (Merkel 2000) attempt to rethink social democracy and 'reprogramm[ed] organisational goals with the aim of adapting to the political environment' (Weßels 2007: 43). What was meant by the Third Way? Anthony Giddens, the intellectual protagonist of the Third Way debate, had criticised the "conservative' nature of socialism and social democracy since the early 1990s, when he recommended the 'preventative welfare-state' as a blueprint for social policy, and advanced the notion of politics 'beyond left and right' (e.g. Giddens 1994). At about the same time, the British Labour Party was modernising its ideology and party organisation. A new generation of party leaders welcomed and appropriated his critique for their project of bringing Labour back into power. 
The wider circumstances that spurred on the rethinking of social democracy were outlined by Lavelle (see Chapter 1 in this volume). Just to recapitulate a few of them: with the end of 'actually existing socialism' in 1989, social democracy's function of transforming the fear of communism into social progress (Mahnkopf 2000) became dispensable. On the other side, neo-liberal policies had failed to achieve their own objective of economic efficiency and were increasingly unable to deal with rising poverty and unemployment. For Giddens, the failure of both paradigms resulted in the obsolescence of the political categories of left and right. He also argued that value systems had changed. Instead of traditional social democratic values of social justice, equality and solidarity, post-materialist values of ecology, individuality, self-realisation, liberty and cultural identity had become important as indicators of progressiveness (Giddens 1998). Therefore, a new 'third way' social democracy needed to transcend the old ways if the centre-left wanted to survive. Giddens advocated his third way as the 'sparking point for a new political framework of comparable importance and influence' to that which Keynesianism on the one hand and free-market liberalism on the other had once had (Giddens 1997: 37).

Most important for this chapter is the Third Way discourse on the function and form of the welfare state and the reconceptualisation of social justice. For the latter, the term 'social inclusion' was paramount. According to Giddens, social inclusion of the individual necessitates, as a first step, participation in the labour market. In order to deal with high (long-term) unemployment, a refocused welfare state, the 'social investment state' (Giddens 1994), should act as a partner and 'springboard' to reattach the individual to the labour market rather than acting as a 'security net' that would keep them in welfare dependency. The Third Way's pejorative description of the welfare state as a security net and of welfare transfers as 'hand-outs' indicated that the discourse of solidarity was giving way to a rights and responsibilities discourse which Giddens recommended as the 'prime motto for the new politics' of the centre-left (Giddens 1998: 65). Giddens recommended that Social Democrats should move 'away from what has sometimes been in the past an obsession with inequality, as well as rethink what equality is' - although he also advised that the centre-left should not accept the idea that high levels of inequality were functional for prosperity (Giddens 1998: 100). For Giddens, equality should not be understood in the material sense of levelling income and wealth differentials through e.g. progressive taxation. Giddens argued that the notion of equality of outcome was not only unrealistic, but also undesirable in the face of new and diverse value orientations which had come with 'individuation'. Therefore, the social investment state should focus on creating equality of opportunity through equal access 
to education and other important services which enable individuals to achieve their full potential (Giddens 1998). As one strand of this strategy, the state should continuously keep the individual 'active' in the increasingly flexible labour market - through job-focused training, qualification measures, assistance in job search activities and increased pressure to take up paid work - in order to prevent and shorten unemployment and the consequent social exclusion and poverty (Giddens 1999).

The social investment, enabling or 'activating state' - the latter is the translation of the term used in the German debate and captures the idea that the state's task is to arouse the potential of individuals in their own best interest - which emerged from third way discourse is quite different to the traditional social democratic notion of the welfare state. This model was focused on the redistribution of income, wealth and power with the aim of greater equality of outcome and social security through the decommodification of labour. The new Social Democrats adopted a model that comprised what Bob Jessop labelled 'productivistic' social policies (Jessop 1992), designed to create the 'citizen-worker' (Levitas 1998) who only qualified for citizen rights if they consistently attempted to participate in the labour market. But it was not only the objectives of this new welfare state which were different, but also its modus operandi. Giddens subjected the traditional, bureaucratic welfare state to the general charge of being inherently inefficient and ineffective. Only a strong civil society could deliver public goods in a more democratic fashion (Giddens 1998).

There are various different interpretations of the meaning of the Third Way (Marquand 1999; Perger 1999; Mouffe 1998) but this is not the place to discuss these different strands of critique. What is important is to note that the Third Way deviated substantially from more traditional social democratic principles and that the Third Way debate and New Labour's success in 1997 gave modernisers in the SPD an ideological blueprint and a window of opportunity to kick-start their own programmatic debate.

\section{The SPD: permanent reformism?}

The most important programmatic moments in the SPD's history are well known: the founding 1875 Gotha Programme, the 1891 Erfurt Programme and the 1959 Bad Godesberg Programme. The latter was adopted after a long debate which was triggered by the harsh election defeats of 1949 and 1953. At Bad Godesberg, the SPD set its course on becoming a catch-all party which aimed to appeal to the growing middle classes as well as to its traditional voters (Padgett 1994). The programme's often-quoted slogan, 'competition as far as possible; planning as far as necessary' (SPD 1959: 9), made unmistakably clear that the SPD had left behind its Marxist past and 
embraced the mixed market economy on the basis of Keynesian economic theory.

To achieve a socially just society, the SPD advocated mildly redistributive income policies to allow everyone a fair stake in socially produced wealth, but refrained from demanding equality of outcome. Widening educational access in order to attain more equality of opportunity became a prime policy instrument to achieve greater social justice. The programme demoted democratic socialism to being an 'enduring task' (SPD 1959: 3) rather than upholding it as the form of a new social and economic order towards which the SPD was striving. ${ }^{1}$ The new programme indeed contributed to the SPD's rising electoral fortunes: in 1966, the Social Democrats become junior partners in a grand coalition with the Christian Democrats, and in 1969 the SPD formed a federal coalition government with the small Liberal Party which lasted until 1982. With Bad Godesberg, the SPD became the role model for programmatic modernisation for the European centre-left.

However, the SPD-led government had very little time to implement its programme of welfare-state expansion and of widening educational access. After the first oil shock in 1973, economic crisis, rising unemployment and the subsequent fiscal austerity of the welfare state led to conflicts between the trade unions and the SPD-led government under Helmut Schmidt and to the strengthening of the party's left wing. The 1975 Orientierungsrahmen 85 (SPD 1975) - a party conference statement meant to update the Bad Godesberg Programme - demonstrated that the economic crisis had undermined the SPD's faith in anti-cyclical macroeconomic policy and its deliberations brought tensions between the right and the left wings to the fore (Padgett 1994). The rise of the new social movements, their transformation from extra-parliamentary opposition into the Green Party and the upsurge of neo-liberal ideology diminished electoral support for the SPD further.

The SPD lost the 1983 elections after its coalition partner had changed sides in favour of the Christian Democrats. This was the beginning of fifteen years in opposition in the Bundestag. Following these elections, there were limited intra-factional disputes within the SPD about its future course which ended in the decision that a systematic programmatic debate was necessary. This Programme Debate, initiated in 1983, took the party over five years to conclude (Kölbe 1987; Padgett 1994).

The December 1989 Berlin Programme was an attempt to come to terms with social and economic changes and offered a bridge between the traditional left and the new social movements. However, the fall of the Berlin Wall just months earlier overshadowed the debate in public perception and almost immediately rendered the programme out of date. 
The programme showed a sharply increased awareness of environmental destruction. The question of how to achieve more material prosperity for all while maintaining a competitive economy was no longer answered by a commitment to continuous economic growth equated with 'progress' but was met by uncertainty on how to reconcile the economy and ecology. Nonetheless, in social policy terms the Berlin Programme had a largely leftwing social democratic character and represented a party keenly aware of its roots in the working class. In contrast to the Godesberg Programme, the Berlin Programme used an explicit class analysis of the current situation and how it should be changed. Referring to capitalism as an obstacle to human emancipation, the programme emphasised that it had been the historic experience of the workers' movement 'that repairing capitalism is not sufficient. A new order of economy and society is necessary'. The struggle for this order would be informed by the SPD's principles of freedom, justice and solidarity, the realisation of which was the enduring task of democratic socialism, as the programme said (SPD 1989: 8, 13). The programme demanded 'greater' equality of distribution of income, property, power and access to education, culture and vocational training without specifying at what point this aim would be achieved. The programme was clear about the importance of the state for the achievement of social justice, but it also acknowledged that its tasks had to be limited. Although the state's responsibility for the creation of paid employment was underlined, the programme also stressed that it should promote lifelong education to enable its citizens to succeed in an increasingly flexible labour market. However, citizenship was not to become dependent on being in paid work. The traditional aim of decommodification was largely maintained, paid employment was not elevated to a panacea for poverty and social exclusion, nor was globalisation celebrated.

\section{Third way and Neue Mitte (1995-98)}

The SPD suffered general election defeats in 1990 and in 1994, while changing its party chairmen three times between 1990 and 1995. In 1992, the party endorsed a special programme which emphasised that it would pursue a policy combination of fiscal prudence, public works and training programmes; it would also stop welfare-state expansion in order to deal with the emerging post-unification budget and unemployment crises (SPD 1992). In November 1995, Oskar Lafontaine was elected the new party chairman. Belonging to the moderate left of the SPD, he had overseen the debate on the Berlin Programme. After 1995, however, he increasingly adopted a modernising discourse especially on economic questions and gained notoriety within trade union circles for his attacks on their alleged 
immobility on questions of labour market flexibility. Nevertheless, the SPD did not manage to clarify its fundamental programmatic orientation under his leadership. The tactical politics of discrediting the governing Christian Democrat-led coalition as immoral neo-liberals and using the SPD's majority in the parliament's Upper House to 'undermine the Federal government's legislative programme and to profile the SPD' (Lees 2000: 90) took priority over elaborating long-term programmatic alternatives.

The development of New Labour, Tony Blair's election victory in 1997 and the emerging debate about the Third Way made an impact on the SPD's leadership. The first sign of programmatic modernisation could be glimpsed in the SPD's late 1997 'Innovation Debate' conference. Nothing in this debate was reminiscent of the Berlin Programme. Most of the contributions embraced the opportunities offered by globalisation and showed an unbridled belief in the possibility of 'ecological modernisation' - combining strong economic growth with environmentalism. Oskar Lafontaine and Gerhard Schröder, the two potential challengers to incumbent chancellor Helmut Kohl, presented themselves as modernisers and traditionalists at the same time. They appealed to all social groups, declaring that only a common effort would ensure that Germany could be modernised according to the 'triad of innovation, work and justice' (Lafontaine and Schröder 1998). To do so, welfare-state reform, public administration modernisation and labour market flexibility would be necessary under the conditions dictated by globalisation. In order to weather globalisation's challenges and to make use of its opportunities, a new partnership between labour and capital would be required. Therefore, Schröder advocated an 'Alliance for Jobs' between state, employers and trade unions to arrive at a consensus on how to reform the country. Abandoning the étatiste preferences of the SPD, Lafontaine stressed that whether a task was performed by the state or by private entities was not a question of ideology, but a question of practical reason. The overburdened state should be relieved of some of its responsibilities because many public services could be provided more adequately by civil society organisations (Lafontaine 1998).

As the Bundestag elections drew nearer, the rhetoric of the debate developed towards the rebranding of the SPD as the party of the Neue Mitte, the new centre, in an attempt to emulate New Labour's success in attracting the median voter. The new discourse tried to reconcile themes such as social justice and solidarity with those of individuality and achievement supposedly held by professional workers, managers and entrepreneurs those who populated the SPD's new centre.

In the 1998 election campaign, little that was concrete was said about what social justice meant for the SPD. Central to the election manifesto was the commitment to full employment on the basis of social partnership 
in a social market economy renewed according to the leitmotif of the 'stakeholder society, in which everybody enjoys their fair share of collectively generated wealth' (SPD 1998: 6). ${ }^{2}$ Overall, the state would reduce its role in economic policy: the required fiscal austerity of a leaner and more efficient state would no longer allow Keynesian-style debt-financed market reflation programmes. The manifesto stressed that the SPD wanted to promote employment, not finance unemployment. More would be done for the creation of new jobs, for more successful job searches and for better job take-up. The SPD also addressed its traditional voters of the working class with promises to revoke most of the cut-backs on employment security and sick pay which were made by the CDU-led government (SPD 1998: 12).

\section{Governing and modernising: the programme debate (1999-2001)}

Election research shows that the SPD really did attract new voters in the 1998 elections and that it won them with its most heterogeneous vote ever (Forschungsgruppe Wahlen 1998). The SPD formed a coalition with the Green Party, with Gerhard Schröder as chancellor and Oskar Lafontaine as head of the powerful finance ministry. The SPD had a particularly difficult start in government. There were three crises within the first year: a steep decline in the SPD's popularity immediately after the elections resulting in a number of Länder election defeats, the leadership dispute between Schröder and Lafontaine, and the programmatic vacuum that developed after Lafontaine's unexpected resignation as finance minister and party chairman in April 1999.

This section will focus on the programmatic crisis, from which the official programme debate leading to the 2007 Hamburg Programme emerged. The new centre rhetoric no longer obscured the contradictions between the SPD's programmatic pledges, Lafontaine's policy preferences, and Schröder's aims in social and economic policy terms. The legitimacy gap between programme and policy could finally be tackled after Lafontaine's resignation, when Schröder became party leader as well as head of government.

An article written by Schröder and Blair in June 1999 started the modernisers' attempt to bring the SPD in line with Schröder's governmental course. It criticised social democracy for its equation of social justice with equality of outcome and attacked its propensity to interfere with markets which were better left undisturbed by state intervention if the wealth required for the upkeep of the welfare state was to be produced. The two leaders recommended a 'supply-side politics from the left' (Blair and Schröder 1999), by which they understood investment in human capital 
and welfare-to-work programmes in order to increase labour supply and the growth of the so-called knowledge-based economy.

The article was critically received by the German media and the SPD. Both its argumentation and the way Schröder attempted to force a programmatic change upon his party through an article perceived as being ghosted by the two leaders' spin doctors turned it into a fiasco. Its effective dismissal by many in the SPD and by commentators in Germany further contributed to the SPD's loss of programmatic confidence. Nonetheless, it showed that Schröder was willing to challenge his party's long-held assumptions about the role of the state, welfare and economic policies and conceptions of social justice. And despite, or perhaps even because of this fiasco, the modernisers convinced the 1999 party convention to launch an official debate for a new party programme ready for adoption in November 2001.

In September 2001, Schröder, as chairman of the Programme Commission, asked the party to suspend the debate in order to concentrate on the 2002 elections. This was agreed and the elections were narrowly won. Afterwards, the debate continued, albeit slowly, during 2003 (Egle and Henkes 2004). A new programme draft was eventually ready for publication in May 2005. However, when Schröder announced early elections for September 2005 this draft was put on ice.

Throughout the debate, senior party leaders and government ministers emphasised the constraints that being in power placed upon a programmatic renewal (e.g. Schröder 2001). The membership of the Programme Commission and its working groups had been arranged to facilitate the modernisation course favoured by Schröder. While the published documentation of the programme debate revealed conflicting views, it was nevertheless dominated by themes and rhetoric identified earlier in the discussion of the Third Way. Rudolf Scharping, the Deputy Chairman of SPD and Managing Chairman of the Programme Commission, made clear that the party's position on the role of the state and the significance of redistribution of wealth and income had to be redefined within the constraints of globalisation. Stakeholding and participation should be considered more important for future social democratic politics than redistributive justice (Scharping 2000). Another leading party member, Wolfgang Clement, embraced limited inequalities according to John Rawls' theory of justice: they were 'catalysts for individual and social opportunities' and led to higher economic productivity, benefiting even the worst off. Furthermore, he recommended labour market deregulation to allow greater fairness in access to employment-promoting social inclusion and therefore more justice (Clement 2000: 11).

Inanintermediatereportin November 2001, theProgrammeCommission confirmed the basic tenets of the Berlin Programme, but stressed that the 
welfare state needed to change its objectives towards making the prevention of unemployment its priority rather than providing support to the unemployed (SPD 2001). Part of the preventative element was improving and extending education, training and lifelong learning to promote equal opportunities in the labour market. For those with lower skills, the generation of a new low-wage-low-skill labour market should be encouraged by reducing the tax and social insurance rates paid by employer and employee in equal parts. This would reduce wage-added costs for employers and thus stimulate job creation. Moreover, jobs would become more attractive, as net wages would rise above benefit levels. Better job search and placement instruments should assist jobseekers to integrate more easily into the labour market. Rather than relying on welfare benefits, unemployed people should assert more self-reliance and take up lower-paid jobs in order to reintegrate into society so that they would not burden public budgets. The guiding principle of future labour market policies should be that of the 'activating state', 'which proposes a new balance of rights and responsibilities, and a new balance of Fördern and Fordern' - to be translated as supporting and demanding (SPD 2001: 65).

The government adopted this principle in its legislation, for example in the December 2001 Job-AQTIV Bill, which was Schröder's first labour market initiative to adopt a welfare-to-work approach.

\section{Agenda 2010 (2002-3)}

Schröder's second term in office proved particularly influential for the programme debate. The government's most important reform project was Agenda 2010 for the "sustainable protection of the welfare state, for more jobs and strengthening of the German economy' (Schröder 2003) from March 2003. Agenda 2010 attempted to integrate the coalition's policy initiatives since 1998 into a cohesive narrative of modernisation. In particular its welfare and labour market reform proposals, based on the report by the government's Hartz Commission in 2002, were highly contentious both with the public and the SPD. A serious conflict ensued inside the party. As a result, Schröder resigned as party chairman and a number of trade unionists left the SPD to form a new political party. This party eventually merged with the Party of Democratic Socialism (PDS) the successor of the ruling party of East Germany - into the Linkspartei. In 2007, it was renamed Die Linke or The Left with Oskar Lafontaine as one of its two chairmen.

What did Agenda 2010 mean for the SPD in relation to its position on social justice and its welfare policies? Schröder declared that the serious economic situation of the country resulted in a stark choice: 'either we 
modernise as a social market economy or we will be modernised by the unfettered forces of the market' (Schröder 2003). Most important was the reorientation of welfare policy towards increasing the employment rate by increasing the pressure on the unemployed: the state would no longer accept that its citizens 'sit back and become a burden to the community. Those who reject reasonable work ... will have to face financial penalties', namely benefit withdrawal. To assist labour market reattachment and thus social inclusion, employability-improving measures and assistance in job search activities were to receive more attention by the state while passive welfare measures such as benefits came to be regarded as undesirable expenditure. Many of these policy initiatives were based on the British New Deal welfare-to-work programme and the British reorganisation of the employment services into the 'one-stop-shop' job centres. An analysis of the documents of this debate reveals that the government addressed social justice exclusively under the banner of the 'justice of equal opportunity' and 'inter-generational justice' and did not address redistributive questions of equality of outcome at all (Bundesregierung 2003).

Agenda 2010 demonstrated the government's conviction that the existing welfare state was responsible for many of Germany's economic problems and its high unemployment rate. Schröder's defence of his new policies was that they were an attempt 'to put justice back on its feet. This is about justice also for future generations ... The politics of the permanent present . . . must be abolished' (Schröder 2004). Nevertheless, the SPD struggled with the growing legitimacy gap between programme and policy as the programme debate continued and was influenced by Agenda 2010. In 2003, the SPD's Secretary General Olaf Scholz maintained that 'the politics of social justice have never been primarily a question of the quantity of social transfers', but about life chances. Only a preventative and social investment state could promote social inclusion and personal responsibility (Scholz 2003a: 7). Franz Müntefering, who had succeeded Schröder as party chairman in March 2004, stated that the welfare state was a "voluntary mutual agreement. Everybody has the duty to use his own strength and ability, and also the right to use the community, when in need'. Furthermore, he emphasised that equality of opportunity was at least as important as distributive equality (Müntefering 2005: 13).

The 'activating' and 'preventative' welfare state had evolved as the new leitmotif of the SPD's programmatic discourse, and despite all the innerparty opposition and public protests, the government stood by Agenda 2010 and the SPD integrated it into its 2005 election manifesto as part of its newly adopted project of 'Soziale Demokratie' (SPD 2005). Soziale Demokratie is not to be confused with Sozialdemokratie: whereas the latter denotes the political movement of which the SPD is the expression as a 
political party, the former describes the specific form of society which the SPD wants to establish. This idea was developed by one of the SPD's most influential thinkers, Thomas Meyer from the party's think-tank FriedrichEbert Foundation (Meyer 2007).

\section{From Bremen Draft to Hamburg Programme (2005-7)}

Although the SPD lost the majority in the Bundestag in 2005, the party nevertheless performed much better than most observers had expected and only received slightly fewer votes than the Christian Democrats. As a result, the SPD joined the Christian Democrats as a junior partner in a grand coalition. Shortly afterwards, Müntefering unexpectedly resigned as party chairman and a window of opportunity for a change of the SPD's programmatic course opened - after all, Hartz reforms and Agenda 2010 were deeply resented by many in the party and the emergence of the Linkspartei to the SPD's left was seen as a major threat to the strength of the party. Nevertheless, when Matthias Platzeck took over the party's top job in October 2005, he made it clear that there would be no substantial change to the modernisation course (Platzeck 2006). He resuscitated the programme debate and announced a new draft programme for early 2007. But Platzeck resigned due to poor health in April 2006 and his successor Kurt Beck continued to struggle with the definition of what the SPD stood for and for whom. He claimed that the SPD was the 'left people's party of the solidaristic centre'3 (Beck 2006: 2) and attempted to defend his party on two fronts: against the Linkspartei taking votes from the SPD and getting non-voters on board, and against the Christian Democrats who were rediscovering their commitment to the welfare state after Angela Merkel's neoliberal 2005 election campaign had been rewarded with one of the party's worst election results in history of just over 35 per cent.

In early 2007, finally, the SPD published a draft programme as the basis of debate for the new Hamburg Programme. This Bremen Draft confirmed the continuing orientation of the party around the fundamental themes of third way discourse. The new draft abandoned any fundamental critique of capitalism and merely maintained that financial markets had to be controlled. The term 'democratic socialism' was not abandoned in favour of 'Soziale Demokratie', as some had demanded (e.g. Scholz 2003b), but was instead listed as only one of many historical influences on the party. At the centre of the draft stood the 'preventative welfare state', whose main task was to reduce long-term unemployment by ensuring that jobseekers take up paid work. By defining education and training as central elements of labour market policy, the SPD put making people employable and adaptable to the needs of the labour market into the foreground of its politics. It 
insisted that in the future, people and not jobs were to be protected. This was firm evidence of the SPD's renunciation of macroeconomic management in favour of supply-side politics. The Bremen Draft maintained the Berlin Programme's demand for 'greater' justice in access to education, social security, culture and in the distribution of income and wealth although the authors emphasised their belief that income should be aligned to performance (SPD 2007a) - a statement unthinkable for the Berlin Programme.

For the first time in the SPD's history, party members were able to comment directly on a draft programme. Out of the party's approximately half a million members, forty thousand responded by completing a short questionnaire which gave little room for direct comments or critical answers. According to the SPD's own published analysis of the poll, the idea of performance-related income inequalities met with scant approval, whereas equality of opportunity polled very highly - the question of e.g. a more redistributive tax system was not featured on the questionnaire. Support for wage subsidies and the state-financed creation of employment in the 'social labour market' was also high, along with approval for a national minimum wage - this issue was not mentioned in the Bremen Draft but had become a topic of hot debate. The concept of the preventative social state and the proposal to focus on assuring employability rather than making jobs secure met with a mixed response (SPD 2007b).

Between April and November, the draft was rewritten following motions from party subsections and an analysis of the members' returned questionnaires. Many of the responses from party branches had been negative in nature, as the SPD's Secretary General admitted later (Heil 2007). During the rewriting process, leading Social Democrats who had served under Schröder and were now in government positions again in the grand coalition warned publicly against the reforms of Agenda 2010 being rejected, as such a leftward shift would render the SPD unelectable for the middle ground of society (e.g. Platzeck et al. 2007). Predictably, these comments provoked conflict with party chairman Beck who was responsible for the redrafting process and who felt less inclined to adhere to his predecessors' policies.

When the October 2007 party conference in Hamburg debated, changed and adopted the Bremen Draft as the new Hamburg Programme, both the new programme and the way in which the conference debated it were publicly perceived as being a leftwards shift. Christian Democrats, including Chancellor Angela Merkel, lambasted the SPD for retaining its commitment to 'democratic socialism' as the party's ultimate goal (SPD 2007c) and most of the mainstream media agreed that the SPD was shifting to the left.

This conclusion, however, needs to be qualified. The programme's first- 
page commitment to socialism and some of conference's decisions produced media headlines and, for the moment, sharpened the SPD's profile both to the right and to the left. First, it reclaimed democratic socialism from Die Linke and, second, it clarified the differences between the SPD and CDU which for many voters and observers had become negligible during the debate about Agenda 2010. However, the contents of the Hamburg Programme are actually very similar to the Bremen Draft. Even the commitment to democratic socialism is shared by both texts, although in the latter it is circumspectly inserted in the main text of the programme rather than in the opening passage. The 'preventative welfare state' remains central to the SPD's future welfare-state model in conjunction with that of the self-organising 'civic society'4 (SPD 2007c: 18). On the distribution of income, wealth and power both the draft and the programme maintained that there should be 'greater' equality. However, both documents also embraced inequalities as long as they did not limit the freedom and capabilities of others: e.g. the programme makes reference to the 'necessity' of acknowledging individual achievement and outstanding performance. The Hamburg Programme also takes what seems to be a tougher stance with respect to the level and role of welfare-state benefits than the Bremen Draft. It states, unlike the Bremen Draft, that the level of social security cannot be measured by the value of transfers (SPD 2007c), a frequent argument during the debates about the Hartz reforms, but should rather be measured by the effectiveness of social policy in reattaching the individual to the labour market.

The Hamburg Programme uses a less managerial rhetoric, its enthusiasm about globalisation is less one-sided and it emphasises that financial capitalism has to be regulated to ensure that it works for the common good. The Bremen Draft refers to 'investment' in people as the main task of the state, whereas the Hamburg Programme says that the state should concentrate on prevention, thus evoking images of a more caring welfare state.

\section{Conclusion}

The Schröder government's perceived constraints were important for the SPD's programme debate. The legitimacy gap between programme and values on the one hand, and what the government understood as realpolitik without alternatives on the other hand, unsettled the party, destabilised the government and probably cost the SPD valuable votes. Schröder never made any concerted effort to establish a 'communicative discourse' (Schmidt 2000) with his party, but rather adopted top-down approaches. The SPD was initially stubbornly opposed to such a de-traditionalisation from above and only the formal process of the subsequent programme 
debate made change possible. Again, however, Schröder failed to commit himself to the debate and left it to other modernisers who had far less weight and influence in the party.

Nevertheless, the Third Way, as we saw above, provided the SPD's modernisers with new ideological input. The concept of social justice and the resulting policies were the 'Archimedic point of the programmatic debate' (Egle and Henkes 2004: 133). The old understanding of social justice was replaced by one that finds its orientation in John Rawls's theory of justice, while the concepts of capability and the enabling state are derived from Amartya Sen's work. The proactive labour market strategy - promoting employability and enforcing job seeking by tough rules on benefit conditionality - and the equation of employment at (almost) any cost with social inclusion were almost opposite to social democracy's traditional decommodification strategy.

The Hamburg Programme is the Third Way 'through and through'. The SPD's main objective, that of struggling for a socially just society, has been given a different meaning compared to the Berlin Programme. The SPD jettisoned much of its critical analysis of society, parted with left-wing intellectualism, paid less attention to environmental issues and adopted a programme that reflected the policies of Schröder's government. The high-profile commitment to democratic socialism on the first page of the programme cannot disguise these changes.

Since the programme was adopted, the SPD's difficulties in defining its identity and policies have persisted. The 2007 convention gave the party rank and file hope that their leadership would distance itself from Schröder's course, while the trade unions were hopeful that the SPD would become their 'natural' ally again. Kurt Beck's position as party chairman was temporarily strengthened after the party conference and he took a confrontational stance against the grand coalition, in particular against some elements of Agenda 2010. He was initially successful in asserting his leadership against inner-party resistance from those committed to Schröder's policies, so that some of the welfare reforms were reluctantly revoked by SPD ministers following instructions from the party conference. The SPD's perceived leftward shift on social policy also seemed to improve the party's poor showing in the polls. But closer to regional elections in Hesse, Lower Saxony and Hamburg in early 2008 the party leadership was forced to come clean on whether the Länder parties would be allowed to form coalition governments with Die Linke if the election results permitted this - a taboo, at least in the West of Germany not only because of personal and policy differences but also because of Die Linke's roots in the East German communist party. Kurt Beck pursued a poorly coordinated course on this issue when he decided that his party should be 
allowed to cooperate with Die Linke on state level but not on the federal level. This strategy was criticised heavily in public and within the party. It widened the gulf between the SPD's left and right wings further and significantly weakened Beck himself. Judging by opinion polls from April 2008 which see the SPD hovering under 30 per cent and ascribe little popularity to its chairman, the programmatic modernisation process has placed the SPD in a difficult position: after losing the post-materialist vote to the Green Party in the 1980s, how can the SPD recapture the traditional voter from Die Linke without giving up the Neue Mitte of society which it had won over, albeit briefly, for the 1998 elections while, additionally, the Christian Democrats are reasserting their welfare-state credentials? The SPD tried to move 'beyond left and right' to broaden its electoral appeal but it seems that currently it finds itself in no man's land.

\section{Notes}

1 The reader will come across three different terms which are of importance for understanding the SPD's ideological outlook: Demokratischer Sozialismus or democratic socialism, Sozialdemokratie - translated as social democracy - and Soziale Demokratie which remains in the German in order to distinguish it from the former and which will be explained in the text.

2 'Teilhabegesellschaft, in der alle ihren gerechten Anteil erhalten am gemeinsam erarbeiteten Wohlstand.' While talking about stakeholding, the manifesto did not explicitly support the legally enshrined provisions for economic codetermination of the workforce through works' councils but does state that reforming Germany necessitates the cooperation of the social partners.

3 'linke Volkspartei der solidarischen Mitte'.

4 'Bürgergesellschaft'.

\section{References}

Beck, K. (2006) Leitsätze auf dem Weg zum neuen Grundsatzprogramm der SPD: http:// programmdebatte.spd.de / servlet / PB / show / 1669218/210406_Leitsaetze _ Programm_final.pdf (accessed 3 November 2006).

Blair, T. and Schröder, G. (1999) 'Der Weg nach vorn für Europas Sozialdemokraten. Ein Vorschlag von Gerhard Schröder und Tony Blair'. Blätter für deutsche und internationale Politik, 7.

Brivati, B. (1997) 'Earthquake or watershed? Conclusion on New Labour in power', in B. Brivati and T. Bale (eds), New Labour in Power: Precedents and Prospects (London: Routledge).

Bundesregierung (2003) Agenda 2010. Deutschland bewegt sich: www.bundesregierung.de/artikel,-693207/Antworten-auf-die-wichtigsten-.htm (accessed 15 May 2005).

Clement, W. (2000) 'Durch Politik zur gerechten Teilhabe', speech, 26 April 2000: 
http://archiv.spd.de/servlet/PB/menu/1010058/index.html (accessed 13 June 2006).

Egle, C. and Henkes, C. (2004) 'In search of social democracy - explaining the politics and policies of the Schröder Government, 1998-2002', in M. Henning and S. Haseler (eds), Reshaping Social Democracy: Labour and the SPD in the New Century (London: European Research Forum at London Metropolitan University).

Forschungsgruppe Wahlen (1998) Bundestagswahl 1998. Eine Analyse der Wahl vom 27. September 1998 (Mannheim: Forschungsgruppe Wahlen).

Giddens, A. (1994) Beyond Left and Right: the Future of Radical Politics (Stanford: Stanford University Press).

Giddens, A. (1997) 'Centre-left at centre stage', New Statesman, May, special edition.

Giddens, A. (1998) The Third Way: the Renewal of Social Democracy (Cambridge: Polity Press).

Giddens, A. (1999) 'Why the old Left is wrong on equality', New Statesman, October.

Heil, H. (2007) Speech at SPD Party Convention, 28 October: www.spd.de/ menu/1731525/ (accessed 7 November 2007).

Jessop B. (1992) 'From the Keynesian welfare to the Schumpeterian workfare state', Lancaster Regionalism Group, Working Paper 45, University of Lancaster.

Kölbe, T. (1987) 'Trade unionists, party activists and politicians: the struggle for power over party rules in the Labour Party and the West German SPD', Comparative Politics, 19 (4).

Lafontaine, O. and Schröder, G. (1998) (eds), Innovation für Deutschland (Göttingen: Steidl).

Lafontaine, O. (1998) untitled contribution in O. Lafontaine and G. Schröder (eds), Innovation für Deutschland (Göttingen: Steidl).

Lees, C. (2000) The Red-Green Coalition in Germany. Politics, Personalities and Power (Manchester: Manchester University Press).

Levitas, R. (1998) The Inclusive Society? Social Exclusion and New Labour (London: Macmillan).

Mahnkopf, B. (2000) 'Formel 1 der neuen Sozialdemokratie: Gerechtigkeit durch Ungleichheit. Zur Neuinterpretation der sozialen Frage im globalen Kapitalismus', Prokla. Zeitschrift für kritische Sozialwissenschaft, 121/30, 4 November.

Marquand, D. (1999) The Progressive Dilemma: from Lloyd George to Blair (Phoenix: London).

Merkel, W. (2000) 'Soziale Gerechtigkeit in Zeiten der Globalisierung. Begründung für eine sozialdemokratische Chancenverteilungspolitik', Berliner Republik, 3/2000.

Meyer, T. (2004) 'Die Agenda 2010 und die soziale Gerechtigkeit', Politische Vierteljahresschrift, 2 (45).

Meyer, T. (2007) The Theory of Social Democracy (Cambridge: Polity).

Mouffe, C. (1998) 'The radical centre: a politics without adversary', Soundings, September, 9. 
Müntefering, F. (2005) 'Wohlstand heute und morgen. Leitsätze zur Zukunft der sozialen Marktwirtschaft', Speech Programmforum, 23 February (Berlin: SPD Parteivorstand).

Padgett, S. (1994) 'The German Social Democratic Party: between old and New Left', in D. Bell and E. Shaw (eds), Conflict and Cohesion in Western European Social Democratic Parties (London: Pinter Publishers).

Perger, W. A. (1999) 'Neue Mitte, Dritter Weg Anmerkungen. Dritter Weg und Neue Mitte: Leerformeln oder Leitbegriffe einer neuen Politik?’ Kongress der Friedrich-Ebert-Stiftung, May 1999 in Bonn. Akademie der politischen Bildung (Bonn: Dietz Verlag).

Platzeck, M. (2006) 'Soziale Gerechtigkeit für das 21. Jahrhundert. Thesen zu einem neuen Grundsatzprogramm', April: www.spd.de/servlet/PB/menu/1053429/ f1666469-e1666913.html (accessed 25 May 2006).

Platzeck, M., Steinmeier, F.-W. and Steinbrück, P. (2007) Auf der Höhe der Zeit: soziale Demokratie und Fortschritt im 21. Jahrhundert (Berlin: Vorwärts-Buch).

Scharping, R. (2000) 'Begrüßung. SPD. (2000) Grundwerte heute: Gerechtigkeit. Materialien zur Programmdiskussion' April (Berlin: SPD). Available from http://archiv.spd.de/servlet/PB/menu/1010058/index.html (accessed 13 June 2006).

Schmidt, V. A. (2000) 'Values and discourse in the politics of adjustment', in F. W. Scharpf and V. A. Schmidt (eds), Welfare and Work in the Open Economy: from Vulnerability to Competitiveness vol. I (Oxford: Oxford University Press).

Scholz, O. (2003a) 'Abschied von der Verteilungsgerechtigkeit' 13 Thesen. Frankfurter Hefte/Neue Gesellschaft, NG/FG 9/2003.

Scholz, O. (2003b) quoted in H. Dietzel (2003) Ist demokratischer Sozialismus noch zeitgemäß? Available from: www.sozialisten.de/politik/publikationen/disput/ view_html?zid=2878\&bs=1\&n=0 (accessed 21 September 2006).

Schröder, G. (1998) Speech at SPD party convention Leipzig, 17 April 1998. Available from www.april1998.spd-parteitag.de/schroeder.html (accessed 27 June 2006).

Schröder, G. (2001) Vorwort. SPD (2001a) Wegmarken für ein neues Grundsatzprogramm. Available from: http://2001.spd-parteitag.de/servlet/ PB/show/1079954/programmdebatte_zwischenbericht2001.pdf (accessed 6 December 2006).

Schröder, G. (2003) Regierungserklärung, 14 March 2003. Available from: http:// archiv.bundesregierung.de/bpaexport/regierungserklaerung/79/472179/ multi.htm (accessed 8 November 2006).

Schröder, G. (2004) 'Natürlich schmerzen Niederlagen', interview, Der Spiegel (28/2004).

SPD (1959) Godesberger Programm der SPD. Grundsatzprogramm (Bonn: Parteivorstand).

SPD (1975) Ökonomisch-politischer Orientierungsrahmen für die Jahre 1975 bis 1985. Reprinted in: Bayerische Landeszentrale für politische Bildungsarbeit, (ed.) (1979) Programme der politischen Parteien in der BRD. Vol. 2 (München: Bayerische Landeszentrale für politische Bildungsarbeit). 
SPD (1989) Grundsatzprogramm der Sozialdemokratischen Partei Deutschlands (Berlin: SPD).

SPD (1992) Petersberger Entwurf: 'SPD Sofortprogramm'. Außerordentlicher Parteitag (Bonn: Parteivorstand).

SPD (1998) Arbeit, Innovation und Gerechtigkeit: SPD-Wahlprogramm für die Bundestagswahl 1998 (Bonn: FES).

SPD (2001) Wegmarken für ein neues Grundsatzprogramm. Available from: http://2001.spd-parteitag.de/servlet/PB/show/1079954/programmdebatte_ zwischenbericht2001.pdf (accessed 6 December 2006).

SPD (2005) Vertrauen in Deutschland. Das Wahlmanifest der SPD. SPDParteivorstand (eds) (Berlin: Willy-Brandt-Haus Materialien).

SPD (2007a) Bremer Entwurf für ein neues Parteiprogramm. Available from: http:// eintreten.spd.de/servlet/PB/show/1700699/bremer_entwurf_navigierbar.pdf (accessed 11 September 2007).

SPD (2007b) Mitgliederbefragung zum Bremer Entwurf. Available from: http:// eintreten.spd.de/servlet/PB/show/1712985/300407_wbhm_mitgliederbefragung.pdf (accessed 8 November 2007).

SPD (2007c) Hamburger Programm 2007 (Berlin: SPD).

Weßels, B. (2007) 'Organisierte Interessen unter Rot-Grün', in C. Egle and R. Zohlnhöfer (eds), Ende des rot-grünen Projektes: eine Bilanz der Regierung Schröder 2002-2005 (Wiesbaden: Verlag für Sozialwissenschaften). 


\title{
The meaning of modernisation: New Labour and public sector reform
}

\author{
Eric Shaw
}

\begin{abstract}
Introduction
If there is a dominant motif in Labour's approach to the conduct of domestic policy, it is 'modernisation' - and its synonym, 'reform'. No set of institutions were more frequently and in a more thoroughgoing and sustained manner the object of modernisation than the public services. 'The reform of our public services', John Reid declared, 'is the crucible in which the future shape of the progressive centre-left politics is being forged' (Reid 2005). It was, the Prime Minister's Strategy Unit announced, 'central to the achievement of the Government's objectives of greater social justice and a higher quality of life for everyone' (PMSU 2006: 13). Under the Blair Government, Michael Barber former head of the PM's Delivery Unit proudly declared, the UK had emerged 'as the most significant laboratory of learning at the cutting edge of public service reform anywhere in the world'. Indeed 'elsewhere in the world Blair's approach is viewed with a mixture of admiration and awe' (Barber 2007: 333). For those who wondered, former No. 10 adviser Peter Hyman advised, where 'the [New Labour] "project" is heading, the renewal of public services provides the answer' (Hyman 2005: 170).

But what does 'modernisation' - or reform - actually mean? This has been the subject of intense debate and controversy. For the government, it was all about ensuring 'that everyone has access to public services that are efficient, effective, excellent, equitable and empowering - and that continually strive to cater to the needs of all citizens' (PMSU 2006: 13). From this perspective modernisation was the use of innovative methods to realise traditional values and goals: we can call this social democratic renewal. For left-wing critics, in contrast, modernisation was, in practice, about marketisation (or commodification). For one commentator the 'Blairite mantra of "modernization"” was 'a slogan for actively dismantling
\end{abstract}


the welfare state while facilitating the introduction of a new market-state under the dominance of private monopoly capital' (Ainley 2004: 508). For another, 'what "reform" now means' was 'marketisation and privatisation, whether frontally or incrementally introduced' (Hall 2003: 22).

Any programme of change is inevitably complex and multifaceted and cannot (or can only rarely) reduce to a single ideological theme. This was particularly true of the host of legislative and other initiatives affecting the public services and set in motion during the decade-long Blair Government. This chapter will, however, argue that an underlying pattern in Labour's approach to the public services (more specifically, secondary education and healthcare, the topics on which this chapter will concentrate) can be uncovered. This will be called 'New Labour Managerialism', a policy project with four interlinked constituent elements: tight performance management, choice, competition and diversity of supply.

The chapter will proceed in the following way. First, it briefly outlines the traditional Labour approach to the public services, labelled the "professional model' and the objections lodged against it by New Labour. Second, it explores the main contours of the Blair Government's alternative model, 'New Labour managerialism'. The third and longest section considers the extent to which this new approach has succeeded in promoting its key objective of higher quality, more equitably delivered services in the two central policy sectors of secondary education and healthcare. This is followed by a brief conclusion.

\section{The New Labour challenge to the professional model}

Underpinning any strategy for organising the delivery of public services is a set of 'institutionalised domain assumptions' (Ranson and Stewart 1994: 42) about how the public services should be organised and operate, how their goals can be most effectively promoted and how those who work within it can best be motivated. These assumptions vary in a patterned way. Thus (drawing here loosely upon Rothstein) one can identify two models or ideal types of organisational functioning. The first, the professional model, places emphasis on the performance-enhancing effect of a professional code, shared norms, trusting relationships and firm habits of cooperation among organisational member. The second - which we call the managerial model - views organisations as incentive systems which respond most effectively to competitive pressures and to performance-related pecuniary rewards (Rothstein 1998: 87).

The former - the professional model - represented the standard social democratic approach to public services and has heavily influenced Labour's thinking throughout its history. Indeed a general confidence in 
'professional expertise and standards reinforced by the orderly controls of rational bureaucracy' underpinned 'the social democratic state' (Ranson and Stewart 1994: 11). Professionalism was understood as behaviour regulated by a professional code of conduct which specified the proper ends of the profession and committed its members to deliver services according to needs in an impartial and equitable manner (Perkin 1989: xiii, 17). Married, in publicly owned and run institutions, with a strong spirit of public service, this code came to be dubbed 'the public service ethos', a concept which deeply permeated Labour thinking 'about the motivation, character and moral importance of the public sector within the political community' (Plant 2003: 561). Broadly speaking, professionals could be relied upon to use the considerable discretion bestowed upon them to do their utmost for those they served, 'trusted to deliver quality services in an efficient, responsive, accountable and equitable fashion' (Le Grand 2007: $18)$.

Professionalism, though, has always had two aspects: on the one hand, the normative, that is expert provision of services regulated by professional standards and ethics and, on the other, the strategic, that is a form of occupational regulation used to advance the interests and institutional standards of professional members by controlling the market for their services (Sullivan 2000: 673-4). In this latter aspect, professionalism, legitimated by the claim to the possession of 'a distinctive - and valuable sort of expertise' operates as a 'basis for acquiring organisational and social power' (Clarke et al. 2000: 8). Policy experts (as well as, of course, seasoned and hard-nosed Labour politicians) working for Labour governments in the 1960s and 1970s were not unaware of this, and of the all too real gap between the public sector ethos as prescriptive code and the actual conduct of those employed within the public sector. For example Richard Titmuss (an adviser to the 1964-70 Labour government) expressed anxiety that as the social services became 'more complex, more specialized and subject to a finer division of labour' the role of professionals would grow and 'collectively, more power may come to reside in the hands of these interests' (quoted in Perkin 1986: 14). Similarly, Brian Abel-Smith (a close associate of Titmuss) mulling over his experiences as a ministerial adviser lamented that within the NHS 'the crucial power still rests with the key professionals both individually and collectively' (Abel-Smith 1984: 180). However - and this was the crucial point - whatever these problems, it was taken more or less as axiomatic in Labour circles, that compared to those working in the profitoriented market sector, public sector professionals would be more likely to be public-spirited, animated by a firmer sense of the common good and more guided in their work by professional norms (Plant 2003). In short, it was supposed that those who worked within the public sector (in a professional 
capacity, like teachers, doctors and nurses) did have a strong sense of the public interest and were 'motivated, at least in part, and for some of the time, by a sense of service and of civic duty' (Marquand 2004: 91).

But what if these assumptions - of professional disinterestedness, of altruism - were incorrect? What if public sector professionals were, in fact, inspired by not dissimilar propulsions than their private sector counterparts? What if, in effect, professionalism was - in part at least - a device for legitimating the entrenchment of producer interests? For a variety of reasons (including their reading of the lessons of the 1974-79 Labour government) the cohort of politicians - initially known as the "modernisers' and subsequently as 'New Labour' - who reached prominence in the 1990s increasingly came to question established party verities. They came to believe that, in the past, Labour had held (in the words of a leading academic sympathiser) distinctly " dewy-eyed" visions of the state and public services' (Stoker 2007: 35). Doubts about the validity of the professional model took the form of two interlinked propositions. The first was a waning confidence "in the reliability of the public sector ethos as a motivational drive and a growing conviction that self-interest was the principal force motivating those involved in public services' (PMSU 2006: 59). The second was encapsulated in Milburn's declaration that 'the inevitable consequence' of any monopoly, public as well as private, 'was unresponsiveness, even indifference to user need' (Milburn 2007: 10). Each of these will be briefly discussed.

\section{Professionalism and the public service ethos as motivational drives} In a reversal of conventional Labour thinking, there was a growing reluctance to view public sector employees as notably more altruistic than their colleagues in private firms. Indeed the concept of the public service ethos, although often lauded for rhetorical purposes, was increasingly viewed with a sceptical eye. Ministerial experience, in particular, of negotiations with shrewd and tough-minded representatives of bodies such as the BMA and the Royal Colleges helped them acquire (as one government insider recalled) 'an extremely jaundiced view of the medical profession' (interview with a former government adviser, 2006). Traditional Labour faith in professionalism had been misplaced. In a system of what Blair called 'professional domination of service provision' professionals had acquired too much power 'to define not just the way services were delivered but also the standards to which they were delivered'. The result was too often a poor standard of service which left service-users 'disempowered and demoralised' (Blair 2004). In the private sector the need to capture custom in highly competitive markets ensured a broad alignment between the selfinterest of the producer and the needs of the consumer. No such restraints 
operated in the public sector - with the result that, too often, services were geared more to 'the interests of its providers than those of its users' (Le Grand 2007: 19). Reflecting upon his extensive governmental experience, Charles Clarke commented that professional associations had too often 'focused upon defence of their own short-term interests despite obvious consumer concerns'. Far from rising to the manifold challenges facing the public services, 'innovation and initiative have been rare and defensiveness and introversion are too often the norm' (Clarke 2007: 134, 131). In the barbed words of one former Downing Street aide, despite much talk of the public service ethos, 'there was not much sense of service to the public' (interview, Geoff Mulgan).

\section{The problem of monopoly}

The professional ethic 'encodes an implicit bargain between professionals and the wider society' in which 'controls over entry are exchanged by a commitment not to abuse their monopoly position' (Marquand 2004: 55). Leading policy-makers in the Blair Government became convinced that the bargain was not being respected. Many of the serious weaknesses from which the public services suffered - inefficiency, unresponsiveness, slowness to innovate, and inequity - stemmed (as a former No.10 health policy adviser put it) less from want of cash than from the endemic flaw of monopoly provision (Le Grand 2006a: 4-5). Central to mainstream social democratic thinking has been the concept of market failure - the inability of the market to meet social needs and distribute resources and life-chances in an equitable manner. This remains an influential strand in New Labour thinking but it has been coupled with an equally strong accent on public sector failure, more specifically the absence of any embedded mechanisms for the enhancement of organisational performance. Without the spur of competition and consumer pressure, public organisations tended to succumb to bureaucratic inertia, a wasteful use of resources, rent-seeking behaviour, weak management and organisational arrangements designed to procure a more comfortable and rewarding life for public servants rather than for those they served (PMSU 2006: 50). In short, by its nature, there were limits to the degree to which any sustained improvements in quality, efficiency and responsiveness could be achieved while a system of monopoly provision of public services continued.

\section{New Labour managerialism}

How could these problems be resolved? In formulating their response, Blair Government policy-makers were heavily influenced by thinking associated with so-called 'New Public Management' (NPM). A definitive NPM tract 
was Osborne and Gaebler's celebrated (1992) text on 'entrepreneurial governance'. This work strongly criticised (in language which was to recur constantly in Blair Government pronouncements) the old-style 'bureaucratic model' of public services which 'delivered the basic, no-frills, one-sizefits-all services' (Osborne and Gaebler 1992: 14). It accepted that the state remained a crucial agency for the pursuit of public goals but could only do so if it were radically reshaped - if it learned to be 'entrepreneurial'. The key characteristics of 'entrepreneurial governments' included the following:

- They promote competition between service providers.

- They empower citizens by pushing control out of bureaucracy, and into the community.

- They measure the performance of their agencies, focusing not on inputs but on outcomes.

- They redefine their clients as customers and offer them choices.

- They prefer market mechanisms to bureaucratic mechanisms. (Osborne and Gaebler 1992: 19-20)

All these themes were assimilated into the discourse and the practice of what I shall call New Labour managerialism (NLM). Like professionalism, NLM defined 'a set of expectations, values and beliefs' about motivation and effective organizational performance - indeed it represented an avowed challenge to it. Thus 'a central issue in the managerialization of public services has been the concerted effort to displace or subordinate the claims of professionalism' (Clarke et al. 2000: 9). NLM, however, should be carefully distinguished from the privatisation/marketisation approach. Thus it was grounded in a strong commitment to a large and vibrant sphere of collective activity where public goods such as healthcare and schooling were provided in an equitable fashion according to need, free at the point of consumption and funded by progressive taxation (PMSU 2007a: 10). But - in a sharp break with traditional Labour thinking - NLM was convinced that the techniques and norms of the private sector and, in some cases, the use of commercial providers, should be harnessed to improve the delivery of public services. 'Old discredited dogmas about what should remain in the public sector and how the public sector operates' must, Brown insisted, be swept aside (Brown 2003).

New Labour modernisation - by the government's second term increasingly came to mean a mixture of four main elements: performance management, choice, competition and 'diversity' of supply (especially the involvement of commercial firms). ${ }^{2}$ In Blair's summary:

We must develop an acceptance of more market-oriented incentives with a modern, reinvigorated ethos of public service. We should be far more radical 
about the role of the state as regulator rather than provider, opening up healthcare for example to a mixed economy under the NHS umbrella ... We should also stimulate new entrants to the schools market. (Blair July 2003)

The next section outlines the four main prongs of NLM. ${ }^{3}$

\section{Performance management}

Performance management can be defined as 'a move towards more explicit and measurable (or at least checkable) standards of performance for public sector organizations, in terms of the range, level and content of services to be provided, as against trust in professional standards and expertise across the public sector' (Hood 1995: 95). The PM's Strategy Unit saw it as composed of four key characteristics:

- targets. These set specific ambitions for improvement in public services and provide publicly available performance information allowing comparisons of the performance of different providers;

- regulation. This includes the setting of (national) minimum standards - which specify the quantity, quality and/or type of service providers should offer users;

- performance assessment, under which providers are monitored and inspected and their performance assessed as to whether they are providing an acceptable level and quality of service;

- intervention mechanisms, which are used to tackle failing or underperforming providers. (PMSU 2006: 22, 34)

Performance management 'was intended to provide a clear and rapid signal that improved outputs and outcomes were expected' from the very substantial additional expenditure being poured into the public services (PMSU 2006: 22). At the summit of the performance management regime was the Prime Minister's Delivery Unit (PMDU). Headed by Michael Barber, it reported directly to the PM and was charged with monitoring and scrutinising key public service targets in especially important or salient policy areas (for an extensive discussion, see Barber 2007). 'By stating the target or goal publicly,' the head of the PMDU explained, 'you create pressure on the system to deliver it and a timetable which drives the urgency' (Barber 2007: 80). Tough targeting 'played a vital role in galvanising public services to deliver ambitious outcomes, building capacity and providing transparency' (PMSU 2007a: 24). It acted - the argument ran - as a battering ram to overcome entrenched inertia. By the same token, through exposure to the intense glare of publicity, league tables placed pressure upon lowachieving providers - schools, hospitals, or whatever - to improve their standard of performance. The threat of intervention if adequate remedial 
measures were not taken would ram home the message that failure was not acceptable (Barber 2007: 334).

However, it was acknowledged that performance management, especially when implemented through a command-and-control approach, could have detrimental effects. It might 'increase bureaucracy; stifle innovation and de-motivate front-line professionals by restricting initiative; and create perverse incentives' (PMSU 2006: 22). Hence in Labour's second term, mechanisms of centralised control abated and the number of detailed targets was curtailed. There was a significant shift towards 'earned autonomy' in which control over organisation, management and finance was devolved to 'good performers' (PMSU 2006: 22, 43). Here, crucial roles were performed by the three key (and interlinked) elements of the so-called 'quasi-market', choice, competition and commercial involvement in supply.

\section{Choice}

Labour's 1945 settlement was (in Tony Blair's words) 'largely statedirected and managed, built on a paternalist relationship between state and individual, one of donor and recipient [one in which] personal preferences were a low or non-existent priority' (Blair 2002). The outcome was an asymmetrical power relationship in which user needs and preferences were often neglected. There were two available mechanisms to liberate the user - voice and choice. The government introduced a series of measures to amplify voice relative to the involvement of service users in decisions which affected their lives. But, for a range of reasons (discussed in detail in Le Grand 2007: 32-6) it was persuaded that to have a substantial impact voice had to be coupled with choice - which soon supplanted it as New Labour's favoured mechanism for enfranchising the 'consumer'.

In fact, the extension of choice was designed to achieve multiple policy goals. Giving choice to the consumer meant that the producer had to gear services to what the user wanted. In a New Labour theme that became steadily more insistent, it promoted 'personalisation' - that is the tailoring of services to the individual needs and preferences of citizens (PMSU 2007: 34). And it put the providers under relentless pressure to improve their actions. In short, by allowing users 'to become more assertive customers', choice helped 'to ensure that public services respond more promptly and precisely to their needs' (PMSU 2006: 65).

By the beginning of the Blair Government's second term in office, the concept of choice had emerged as a crucial organising principle in its public sector strategy. Thus in education the government legislated for a diverse range of schools, including faith schools, specialist schools, trust schools and City Academies, from among which parents were increasingly free to choose. The underlying assumption was that 'a quasi-market of 
increasingly differentiated and autonomous schools would . . . foster competition and improvement of performance, while services would become more accountable when they were made to respond directly to the choices of individual consumers' (Ranson 2003: 465). Similarly, in the NHS patients were increasingly offered choice of treatment in a range of hospitals (including private and even overseas ones). By 2008 it was planned that all patients would be able to choose between any healthcare provider provided the price was reasonable and the quality met NHS standards (Department of Health 2006: Ev 3. For a more detailed discussion, see Shaw 2007: 100-3).

\section{Competition}

On its own however, the government maintained, 'the introduction of choice is unlikely to drive dynamic efficiency improvements' (PMSU 2006: 66). For choice to work effectively, producers must learn to compete for custom. Competition, Le Grand explains, "is simply the presence in the public service of a number of providers, each of which, for one reason or another, are motivated to attract users of the particular service' (Le Grand 2007: 41). As in the private sector so in the public, only when coupled with competition could choice "provide powerful and continuing incentives for service providers to improve efficiency and raise service quality for all' (PMSU 2006: 66). In the more competitive environment created by quasimarkets the more inventive, efficient and innovative providers would flourish at the expense of their more sluggish, less efficient counterparts offering a lower standard of service (Dawson and Dargie 2002: 36). Faced by loss of market share and shrinking income, inferior suppliers would either have to raise their game - or face the consequences (Le Grand 2007: 43).

All this required a system in which provider funding was related to demand for services. For this reason a fundamental aspect of the New Labour reform programme was to institute systems by which resource allocation was, at least in part, a function of user demand. In the NHS - to take the best example of this - this took the form of Payment by Results. Under the traditional system of NHS financing through block grants, Tony Blair claimed, 'there were no financial incentives to treat more patients, nor for hospitals to cut their costs. This meant that the inefficient hospitals would have little incentive to improve ... Nor was there any incentive to be efficient' (Blair 2006). Under Payment by Results (PbR), introduced in stages from 2002, hospitals were reimbursed for the activity they actually carried out, using a tariff of fixed prices that reflected national average costs (Maybin 2007: 1). PbR would reward efficiency since where costs were lower than the tariff the surplus could be retained by the hospital and reinvested. Further, under the system of uniform prices, an essential element in the $\mathrm{PbR}$ package, providers would have to compete on quality rather than 
price (Maybin 2007: 4). In education, although no reform as sweeping as $\mathrm{PbR}$ was introduced, there were a range of measures which ensured that schools with the heaviest demand benefited financially by linking funding settlements to enrolment size.

\section{Commercial involvement}

There was, the Strategy Unit argued, 'no point in empowering citizens if their expressed preferences cannot be met' and this entailed 'a broad base of suppliers' (PMSU 2007a: 44). A central tenet of New Labour thinking was that public services did not have to be delivered by public organisations. What mattered was that key services (such as schooling and healthcare) should be provided according to need and free at the point of consumption. The question of who exactly supplied them - whether public, private or voluntary organisations, or some combination of them - should be judged on strictly pragmatic grounds. A distinction was thus made between two functions of the state, as direct provider and as commissioner (and regulator) of services. Rather than insisting on its right to provide all services directly, 'the enabling state' should 'help to empower citizens by introducing much greater diversity of service provision - extending the choices available to users and ensuring that the best providers (whether from the public, private or voluntary sector) are used' (PMSU 2007b:14).

The increased diversity of providers, the government insisted, would shake up old ways of doing things, promote innovative practice, act as a spur to efficiency and foster greater responsiveness. Although much was made of involving the so-called 'third sector' - voluntary organisations and charities - in public service delivery the cutting edge of the government's approach, and perhaps the single most controversial item in the strategy of public sector reform, was increasing reliance on the private sector. The Office of Public Services Reform was confident that 'widening the market to create more suppliers of public services' - greater 'contestability' in the jargon - would 'drive up performance, improve the quality of management and secure more value for money'. It was vital for productivity growth, since, the OPSR noted, 'in the private sector as much as half of all productivity gains come from new entrants to the market, as opposed to incremental improvements from existing companies' (OPSR 2002: 24). All this constituted open defiance of one of Labour's traditional totems and there was furious opposition, especially from the unions. But Tony Blair was adamant. 'If we back off from this one', he declared defiantly in June 2001, 'we might as well pack our bags and walk out of this building now'. 'Part of any reform package' had to be 'partnership with the private or voluntary sector' (quoted in Seldon 2007: 42, 69).

The most contentious example of this policy was the introduction of 
private providers into the delivery of NHS healthcare. In 2002 the first wave of so-called Independent Sector Treatment Centres (ISTCs) was commissioned. Under ISTC agreements private providers were contracted to carry out relatively simple, high-volume surgical procedures, initially in the fields of ophthalmics and orthopaedics. The intention was that the private sector would provide up to 15 per cent of all affected procedures by 2008 (Health Select Committee 2006: 7; Guardian, 26 January 2005). Only with the recruitment of fresh and eager entrants, it was argued, could a truly competitive market be created (Department of Health 2006: Ev 2-3; PMSU 2006: 54). The government removed any doubts about its enthusiasm for a mixed economy of healthcare when a Health Department White Paper published in January 2006 announced a plan to open up primary care to commercial bidders (Guardian, 31 January 2006). A further step was taken when private firms were invited and encouraged to bid to secure contracts for the commissioning of services at primary trust level, thereby performing functions which previously had been discharged solely by public institutions. In education, the introduction of private (and 'third sector') providers proceeded at a tardier pace. The key initiative here was the expansion of the 'City Academy' programme. In return for providing up to 10 per cent of the capital costs, capped at a contribution of $£ 2$ million, 'external sponsors' from the business sector, voluntary organisations and other public sector institutions (e.g. universities) were given a considerable say over how a City Academy was run (Shaw 2007: 68-70).

\section{The impact of New Labour managerialism}

There has been much debate - at times at an emotional tempo - in the Labour party and among academic commentators about how effective 'New Labour managerialism' has been in achieving its ostensible goals. For its harshest critics on the left, it was essentially a programme of marketisation. Thus in healthcare (the charge ran) the NHS was being 'dismantled and privatised .... and commodified. The institutions that made the NHS strong, economical and popular are being dissolved ... In their place are market mechanisms: invoicing, customers, segmented risk pools, legal contracts, and a myriad of competing suppliers' (Pollock 2004: 1, 214, 215). In education, similarly, increasingly 'everything was for sale' with the displacement of use values by exchange values and the increasing intrusion of consumer culture (Ball 2004). For more sympathetic voices, in contrast, talk of privatisation was 'nonsense'. The reforms were 'in the means, not the aims: market dynamics are to be harnessed in the service of equity and social solidarity' (Klein 2006: 411).

Given the relatively short time span - it takes a number of years for 
legislation to be implemented and for their effects to be fully assessed - and the often staggering complexity of the issues involved any judgment on the impact of the many initiatives associated with NLM necessarily has to be tentative. Because this chapter is primarily concerned with Labour thinking - rather than with general issues of public policy - as well as for reasons of space, the focus in the discussion that follows will be on the central question of whether the NLM project of public service reform has advanced the Labour Government's two crucial objectives: greater equality of access to public services and a sustained improvement in their quality.

\section{Greater equality of access?}

In the market, the quality and quantities of what people buy is principally a function of their purchasing power. Given that income, and hence purchasing power, is unequally distributed, markets are thus inherently inegalitarian. But quasi-markets, of the sort introduced by the government, differed from conventional markets in a crucial respect. The supply of services did not respond to purchasing power, since consumers did not individually procure services. Rather, the government acted as an agent on their behalf. Thus though providers compete for their custom, users 'do not come to a quasi-market with their own resources to purchase goods and services, as with a normal market. Instead the services are paid for by the state but with the money following users' choices through the form of a voucher, an earmarked budget or a funding formula' (Le Grand 2007: 41). In effect, purchasing power was equalised in that the value of each choice (user preference) was a function of need (as determined by public authorities) and not ability to purchase. Where prices were extensively used (as in the NHS system of Payment by Results) they were administered - set by public authority - rather than reflecting the balance of supply and demand (Barber 2007: 335). For one of the architects of the quasi-market in healthcare, Julian Le Grand, it was 'a fundamentally egalitarian device, enabling public services to he delivered in such a way as to avoid most of the inequalities that arise in normal markets from differences in people's purchasing power' (Le Grand 2007: 41).

However, this broad claim has been much contested. The key issue - for many critics - is the social distribution of the capacity to make informed decisions. They argued that choice and competition mechanisms would inevitably skew services in favour of the more knowledgeable, educated and confident: that is, the professional and managerial middle classes. 'The articulate and self-confident middle classes', Roy Hattersley contended, 'will insist on the receipt of the superior services. The further down the income scale a family comes, the less likely it is to receive anything other than the residue which is left after others have made a choice' (Hattersley 
2005). Those able to exploit choice most effectively would be service-users from more comfortable and more highly educated backgrounds "with the capability, time and resources to make informed and determined choices' (Rustin 2004: 93). The logic of a quasi-market would therefore be to entrench middle-class advantage.

The government, in contrast, insisted that it had been monopoly public provision that had signally failed to narrow stubbornly high levels of inequality in the distribution of public services. This was not by chance. In the state sector, in the absence of choice, it was the "more articulate, more confident, and more persistent' middle class that gained most from 'voice' mechanisms (Le Grand 2006b). Furthermore, the more affluent sections of the middle class always enjoyed the option of choice by buying into privately supplied healthcare and education. The government was giving to all the opportunities of choice which had until now been the prerogative of the wealthier (Blair 2003).

Adjudicating between the two positions in no easy task. Insufficient data have as yet been accumulated and not enough time has elapsed for researchers to assess the cumulative effects of government reforms (Lewis and Dixon 2005: 13). In addition, it is extremely difficult to disaggregate the impact of one particular set of variables - the effects of government policies - from a host of others (Smithers 2007: 383). As a result, no consensus view has emerged. To take - for illustrative purposes - the issue of secondary education. On the one hand, Gorard and Fitz found "no evidence ... to link education markets with increasing concentrations of disadvantaged children in some schools and their absence in others' (Gorard and Fitz 2006: 281). Indeed, there was evidence of 'some narrowing of the attainment gap between the most deprived and least deprived' (Hill 2007b: 271). On the other, academic research has indicated that competitive markets in schooling has promoted social polarisation. Machin and Stevens found that a 'quasi-market in education has actually reinforced existing inequalities in the education system. Children from lower income and social-class backgrounds ... are now even more concentrated in less-well-performing schools' (Machin and Stevens 2004: 164; see also Harris and Ranson 2005: 574; Besley and Ghatak 2003: 245; Shaw 2007: 73-6). Equally, no clear agreement has emerged over the impact of choice and competition on equity in the delivery of NHS healthcare (Thorlby and Turner 2007; Shaw 2007: 111-13).

Improving the quality goods of public services

What of the debate over the second key objective, bolstering standards in public services? There is no doubt that there have been some notable accomplishments. In education, schools are better funded, better staffed, 
better housed and given better facilities, class sizes have fallen, literacy and numeracy standards risen and overall pupil performance (as measured examinations) steadily improved (Johnson 2004: 195-6; Barber 2007: 266). Similarly in an audit of the Blair Government's record on healthcare published in 2005 the King's Fund reported 'huge progresses in the reduction of waiting times' and 'more and better services' (King's Fund 2005: 8). For example, in 1998 more than one-quarter of patients waiting for elective surgery in England faced a delay of at least six months for surgery, and over 4 per cent for more than a year. By 2005, there was no one waiting longer than a year and only 5 per cent waiting longer than six months (Le Grand 2007: 24; Bevan and Hood 2006: 526).

A necessary condition for higher service quality has been the major upswing in expenditure. Thus, in healthcare, there was an average annual increase in real terms in health spending of 7.4 per cent between 2002/03 and 2007/08 (Department of Health 2003: 4). Equally in education between 1996-97 and 2006-7 public expenditure rose from 4.8 per cent of GDP to 5.7 per cent (Smithers 2007: 379). But the sufficient condition - New Labour insisted - was 'modernisation'. Consumer pressures in a more competitive setting, in particular, was seen as the crucial lever for progressive performance enhancement. Here, in developing its quasimarket reform programme, the government was faced with the problem of designing an effective mechanism to ensure that the dynamic of market competition could be replicated in the public sector. How could consumer pressure be effectively exerted in the absence of a properly functioning price mechanism to guide choice? One response was for the state itself to supply information and advice which would enable the user to make an informed choice between rival providers. Thus in the NHS a scheme of healthcare advisers was introduced (PMSU 2007a: 35; Barber 2007: 336; Le Grand 2007: 84-5, 117-19). However, there were plainly limits to how far this could extend without creating a new - and given the type of expertise required - very expensive layer of officialdom. What was clearly required was some form of price surrogate - a mechanism which could in some way mimic the role of prices as summary quality indicators.

In fact, the mechanism had already been created (in embryo) by the Tories: published information about comparative provider performance. Under New Labour, the practice was developed and extended taking the form, in secondary education, of league tables, the star ratings system in the NHS and, for universities, the Research Assessment Exercise. The aim was to 'measure current or past performance of comparable service units against one another' (Hood 2007: 95). The underlying principle was that the desire to attract custom by securing a higher place in a competitive ranking system would drive up standards (Albury 2007: 150). For 
example, school league tables acted as price proxies by - in Blair's words - giving 'parents the information that has enabled them to make objective judgements about a school's performance and effectiveness' (Blair 2005).

But ranking systems would only act as reliable price surrogates to the extent that they were fashioned out of quantitative indicators which accurately measured comparative performance. 'Clear performance criteria and good-quality performance information' - as a senior adviser in the Prime Minister's Strategy Unit reported - were 'key prerequisites for a wellfunctioning market (Albury 2007: 154). For this, two conditions had to be met: (1) that the performance indicators used to compile ranking orders accurately measured what they were supposed to measure; (2) that performance indicators provided 'a complete and accurate picture of overall performance' (Bevan and Hood 2006: 520).

The first point will be (for reasons of space) briefly discussed. The key issue was the robustness and objectivity of performance indicators. Here the danger was that given so much depended upon one's place in a ranking order there would always be a temptation to engage in 'gaming', that is the management of statistics to place a favourable gloss on performance (Bevan and Hood 2006: 521). For instance - as a former top government adviser reported - pupils might be discouraged from taking subjects in which it was harder to score a good grade (Hill 2007b: 279). Precisely how large a problem this is is difficult to establish, since, as Hood points out, 'we know relatively little about the validity and reliability of complex composite performance measurement systems' (Hood 2007: 100. For a useful general discussion, see also Hood 2006: 517. For secondary schooling, Smithers 2007: 333-9; higher education, Broadbent 2007: 194 and the NHS, Bevan and Hood 2006: 533).

The second point - the extent to which the quality of service provision can be accurately measured - is more fundamental. It is generally agreed that some form of performance measurement is essential to establish accountability, assess standards and single out cases of poorly delivered services (Gleeson and Husbands 2003: 50). The issue is the scale of and weight assigned to performance measurement. Referring to schooling, the chief executive of the Qualifications and Curriculum Authority (Ken Boston) commented that 'no other country devotes as much time and expertise to developing measures of pupil progress' (quoted in Hill 2007b: 279). Indeed, Hood contends that the Blair Government 'arguably took the target approach . .. to a point hardly seen since the demise of the USSR' (Hood 2007: 96). The underlying rationale is that the quality of a service can be established with some accuracy and precision by constructing measured indicators of performance - preferably some form of 'metric' - which, in turn, can be used to compare relative performance. Hence the so-called 
'audit explosion' (Marquand 2004: 111-12) as a myriad of organisations were created 'engaged in checking, measuring and appraising the performance of public sector workers measured against targets and performance indicators' (Gleeson and Knights 2006: 282).

The claim that the standard of services can be accurately measured has been queried by a number of commentators. The argument, in brief, runs like this: unlike in consumer markets. public services are complex, multidimensional and do not lend themselves to being broken down into quantifiable discrete 'products'. As Smithers observes, 'test and exam scores are not a product in the sense that barrels of oil and baked beans are: they are surrogates for the education we hope are taking place' (Smithers 2007: 382. See also Ranson and Stewart 1994: 28). The result of the importance assigned to numerical indicators is that incentives are imparted to concentrate effort on the measurable at the expense of the non- (or not easily) measurable. 'For example, good education involves students being able to achieve high scores in standardized tests, but also encouraging a spirit of creativity, curiosity, and inculcation of good values. The former is easy to measure, but if teachers are rewarded just on the basis of the performance of students in tests, this might lead to an excessive focus on test-taking skills at the expense of the other components of a good education' (Besley and Ghatak 2003: 239. See also Gleeson and Husbands 2003: 502. For higher education, see Broadbent 2007: 195).

Similar criticism has been made of the heavy reliance on measured performance in the NHS. Summarising research published in 2007 on this topic, the editor of the British Medical Journal concluded that:

Focusing on process rather than clinical outcomes reduces clinical complexity to a series of boxes for ticking and encourages overtreatment and medicalisation ... Given the complexity of health care, what are the chances of coming up with a single overall measure of performance? ... people prioritise. This means that performance on one measure may tell you little about performance on others. (Godlee 2007: 24)

In short, given that organisations are rewarded (or penalised) on the basis of measured performance energies are likely to be lavished on scoring well (hitting targets, and so forth) on the measures (Besley and Ghatak 2003: 239). Reducing waiting list time for treatment for life-threatening illnesses, such as cancer, would be widely regarded as a valid measure of performance as long as the statistical evidence is robust. The same would apply to literacy and numeracy targets. However, there are a host of other indicators whose reliability, generalisability and significance may be disputed. More fundamentally, there are activities that simply cannot be accurately measured, or at least not without a major engagement of energy 
and resources, because they are intrinsically qualitative in character, for example the development of intellectual curiosity or aesthetic sensibility. Indeed, there may be an inverse relationship between 'objective' statistical indicators - e.g. measures of productivity - and the actual quality of service supplied, whether assessed in terms of professional judgement or user appreciation. For instance, the care and attention that might be committed by a clinician in easing the anxieties of a patient may - because time is not being effectively 'utilised' - translate into lower productivity scores. As the editor of the British Medical Journal put it:

There can be little doubt that we must constantly evaluate how we are doing, against each other and over time. The problem is that the things that are easiest to measure are almost inevitably the least important, and vice versa ... Compassion and dignity are hard to measure. (Godlee 2007: 24)

\section{Conclusion}

The 'New Labour managerialism', it has been suggested, amounted to a reasonably coherent package of ideas and policies. Initially it evolved slowly and haltingly, but gained pace and impetus in Blair's second term as 'public sector reform' emerged as the central thrust of the New Labour project. Several of its most distinctive and controversial elements, including the accent on competition, choice and private involvement did not (so the press briefings suggest) have the full support of Gordon Brown. So would New Labour managerialism survive the Brown succession intact?

Initially it seemed not. The expansion of the ISTC programme was halted and reports circulated that the new Prime Minister wished, if not to turn back the tide, at least to proceed with far more circumspection. But after a period of initial doubts and hesitations it became evident that Brown was no less enthusiastic a proponent (for whatever reasons) of NLM than his predecessor. And in a heavily trawled and widely publicised article in the Financial Times he promised 'a greater diversity of providers, more choice and in many areas more competition'. He made his position on public service reform unequivocally clear: 'there can be no backtracking on reform, no go-slow, no reversals and no easy compromises'. He promised a faster expansion of the contentious City Academies programme, more personal budgets and more participation by private sector in the delivery of NHS care (Financial Times, 9 March 2008). There will be, so to speak, no turning back.

Labour's approach to the public services has thus undergone a major recasting. Trust and confidence in the motivational force of professional codes and the public service ethos has ebbed and much more confidence is now reposed in the energising and bracing effects of competition and 
pecuniary incentives (Hill 2007a: 248). 'New Labour managerialism' is not - this chapter has suggested - comparable to new right-style privatisation and marketisation programmes. On the contrary, there has been a major hike in the monies assigned to the public services, especially healthcare and education. The decade-long Blair Government witnessed a major refurbishment in the fabric of the welfare state.

However, some of the means used to renovate the public services have been - from a traditional social democratic perspective - highly controversial, notably the systematic importation of methods, disciplines and techniques drawn from the market sector. For the government, the effect will be to realise 'our progressive and social democratic aspirations' such as 'a higher quality of life for all, greater social justice, empowerment for individuals, families and communities, and an enhanced public realm' (Albury 2007: 145-6. See also Le Grand 2006a). Critics, in contrast, fear that equality and quality will both suffer and that the ultimate impact of efforts to render public services more 'answerable to the pressure of competition and the incentive of relative advantage in the marketplace' will be to fragment, corrode and devalue them (Ranson 2003: 470. See also Gleeson and Knights 2006: 281). Only the passage of years will tell which of these two predictions will prove more accurate.

\section{Notes}

1 For reasons of space this chapter focuses on the two public services where reform was most controversial within the Labour party: healthcare and education.

2 There were other elements too but increasingly these were presented as the key motifs. See e.g. Seldon 2007: 42-4, 69-72, 109, 114-15,

3 This section draws upon government documents, interviews conducted with a number of ministers and political advisers and a rapidly growing literature. For details, see Shaw 2007.

\section{References}

Abel-Smith, B. (1984) ‘Social welfare', in B. Pimlott (ed.), Fabian Essays in Socialist Thought (HEB: London).

Ainley, P. (2004) 'The new "market-state" and education', Journal of Education Policy, 19 (4).

Albury, D. (2007) 'Competition for social justice markets and contestability in public services', in P. Diamond (ed.), Public Matters: the Renewal of the Public Realm (London: Politico's Publishing).

Ball, S. J. (2004) 'Education for sale! The commodification of everything?' King's Annual Education Lecture Institute of Education, University of London: www. asu.edu/educ/epsl/CERU/articles/CERU-0410-253-OWI.pdf. 
Barber, M. (2007) Instruction to Deliver: Tony Blair, Public Services and the Challenge of Achieving Targets (London: Politico's Publishing).

Besley, T. and Ghatak, M. (2003) 'Incentives, choice and accountability in the provision of public services', Oxford Review of Economic Policy, 19 (2).

Bevan, G. and Hood, C. (2006) 'What's measured is what matters: targets and gaming in the English public healthcare system', Public Administration, 84 (3).

Blair, T. (2002) 'The courage of our convictions: why reform of the public services is the route to social justice', speech to the Fabian Society.

Blair, T. (2003) 'Progress and justice in the 21st century', Fabian Society Annual Lecture, Fabian Society, 17 June.

Blair, T. (2004) speech at the Guardian's public services summit, January.

Blair, T. (2005) speech on education, October.

Blair, T. (2006) speech to New Health Network, April.

Broadbent, J. (2007) 'If you can't measure it, how can you manage it? Management and governance in higher educational institutions', Public Money and Management, June, 27 (3).

Brown, G. (2003) 'A modern agenda for prosperity and social reform', speech to the Social Market Foundation, 3 February.

Clarke, C. (2007) 'Effective governance and the role of public service professionals', in P. Diamond (ed.), Public Matters: the Renewal of the Public Realm (London: Politico's Publishing).

Clarke, J., Gewitz, S. and McLaughlin, J. (2000) 'Reinventing the welfare state' in J. Clarke et al. (eds), New Managerialism, New Welfare (Milton Keynes: Open University Press).

Dawson, S. and Dargie, D. (2002) 'New Public Management: A discussion with special reference to UK health', in K. McLaughlin, S. P. Osborne and E. Ferlie (eds), New Public Management: Current Trends and Future Prospects (London: Routledge).

Department of Health (2003) Building on the Best Choice: Responsiveness and Equity in the NHS (London: The Stationery Office).

Department of Health (2006) Written Evidence submitted to Health Select Committee hearings on ISTCs.

Diamond, P. (ed.) (2007) Public Matters: the Renewal of the Public Realm (London: Politico's Publishing).

Evetts, J. (2003) 'The sociological analysis of professionalism', International Sociology, 18 (2).

Gleeson, D. and Husbands, C. (2003) 'Modernizing schooling through performance management: a critical appraisal', Journal of Education Policy, 18 (5).

Gleeson, D. and Knights, D. (2006) 'Challenging dualism: public professionalism in "troubled" times', Sociology, 40 (2).

Godlee, F. (2007) 'Careful what you measure', British Medical Journal, 335 (7629), 24 November.

Gorard, S. and Fitz, J. (2006) 'What counts as evidence in the school choice debate?', British Educational Research Journal, 32 (6). 
Hall, S. (2003) 'New Labour's double shuffle', Soundings, 24, autumn.

Harris, A. and Ranson, S. (2005) 'The contradictions of education policy: disadvantage and achievement' British Educational Research Journal, 31 (5).

Hattersley, R. (2005) 'Memorandum to Public Administration Select Committee', in Choice, Voice and Public Services: Volume III Oral and Written Evidence (London: The Stationery Office).

Health Select Committee (2006) Independent Sector Treatment Centres (London: The Stationery Office).

Hill, R. (2007a) 'Governing effectively', in P. Diamond (ed.), Public Matters: the Renewal of the Public Realm (London: Politico's Publishing).

Hill, R. (2007b) 'Education, education, education', in P. Diamond (ed.), Public Matters: the Renewal of the Public Realm (London: Politico's Publishing).

Hood, C. (1995) "'The New Public Management” in the 1980s: variations on a theme', Accounting Organisation and Society, 20 (2/3).

Hood, C. (2006) 'Gaming in Targetworld: the targets approach to managing British public services', Public Administration Review, 66 (4).

Hood, C. (2007) 'Public service management by numbers: why does it vary? Where has it come from? What are the gaps and the puzzles?', Public Money and Management, April.

Hyman, P. (2005) One out of Ten (London: Vintage).

Johnson, P. (2004) 'Education policy in England', Oxford Review of Economic Policy, $20(2)$.

King's Fund (2005) An Independent Audit of the NHS under Labour 1997-2005 (London: King's Fund).

Klein, R. (2006) 'The troubled transformation of Britain's National Health Service', New England Journal of Medicine, 355 (4).

Le Grand, J. (2006a) 'The Blair legacy? Choice and competition in public services', London School of Economics, 21 February.

Le Grand, J. (2006b) 'Equality and choice in public services’, Social Research, June. Le Grand, J. (2007) The Other Invisible Hand (Princeton: Princeton University Press).

Lewis, R. and Dixon, J. (2005) NHS Market Futures: Exploring the Impact of Health Service Market Reforms (London: King's Fund).

Machin, S. and Stevens, M. (2004) 'The assessment: education', Oxford Review of Economic Policy, 20 (2).

Marquand, D. (2004) The Decline of the Public (Cambridge: Polity).

Maybin, J. (2007) Payment by Results briefing, October, King's Fund.

Milburn, A. (2007) 'A 2020 Vision for Public Services', London School of Economics, May.

Osborne, D. and Gaebler, T. (1992) Reinventing Government: How the Entrepreneurial Spirit is Transforming the Public Sector (London: Addison-Wesley Publishing).

OPSR (2002) (Office of Public Services Reform) Reforming our Public Services: Principles into Practice (London: OPSR).

Perkin, H. (1989) The Rise of Professional Society (London: Routledge).

Plant, R. (2003) 'A Public Service Ethic and Political Accountability', Parliamentary Affairs, 56(4). 
Pollock, A. (2004) NHS plc (London: Verso).

PMSU (2006) (Prime Minister's Strategy Unit) The UK Government's Approach to Public Service Reform (London The Stationary Office).

PMSU (2007a) (Prime Minister's Strategy Unit) Building on progress: Public Services Policy Review (London: The Stationery Office).

PMSU (2007b) (Prime Minister's Strategy Unit) Building on Progress: the Role of the State (London: The Stationery Office).

Ranson, S. (2003) 'Public accountability in the age of neo-liberal governance', Journal of Education Policy, 18 (5).

Ranson, S. and Stewart, J. (1994) Management for the Public Domain: Enabling the Learning Society (London: Macmillan).

Reid, J. (2005) Limits of the Market, Constraints of the State (London: Social Market Foundation).

Rothstein, B. (1998) Just Institutions Matter (Cambridge: Cambridge University Press).

Rustin, M. (2004) 'Rethinking audit and inspection', Soundings, 26, spring.

Seldon, A. (2007) Blair Unbound (London: Simon \& Schuster).

Shaw, E. (2007) Losing Labour's Soul? New Labour and the Blair Government (London: Routledge).

Smithers, A. (2007) 'Schools' in A. Seldon (ed.), Blair's Britain, 1997-2007 (Cambridge: Cambridge University Press).

Stoker, G. (2007) 'The state, the citizen and public services', in P. Diamond (ed.), Public Matters: the Renewal of the Public Realm (London: Politico's Publishing).

Sullivan, W. M. (2000) 'Professionalism and professional identity', Canadian Medical Association Journal, 162 (5).

Thorlby, R. and Turner, P. (2007) Choice and Equity (London: King's Fund). 


\title{
Reformism in a 'conservative' system: the European Union and social democratic identity $^{1}$
}

Gerassimos Moschonas

\begin{abstract}
Introduction
Although the foundations and reference points on which the historical social democratic movement was built have not been completely undermined or exhausted, since the 1970s social democracy has been experiencing considerable change. During the 1990s in particular, social democracy underwent a phase of programmatic renewal. The evidence for this renewal abounds: openness to feminist ideas, minority rights, ecology, the adoption of a more pro-European stance, and, last but not least, the adoption of core neo-liberal policy priorities. It is clear evidence not just of renewal but of a veritable programmatic fever. Furthermore, undoubtedly innovative governmental policies, like that of the British Labour Party, to some extent the Gauche plurielle in France and the policies of the Scandinavian Social Democrats or - more recently - the Spanish Socialists have set the tone for socialist action in government. However, this programmatic fever has not generated an image of genuine ideological originality. This situation is paradoxical: in a period of rich programmatic developments, social democracy is often perceived as a force bereft of ideas, programmatically exhausted.

There are only apparent paradoxes in politics. The new orientation of the socialist parties has been perceived as a kind of de-social democratisation of past programmatic options; as an ideological and programmatic retreat, marked by the adoption of opponents' ideas. This perception, which is to some extent unjust given the richness and versatility of the new programmatic developments, has its deepest and firmest foundation in the inability of contemporary social democrats to manage effectively the famous "social question', which is the main vector of their historical identity. Accordingly, doubts as to social democratic 'originality' seem only natural. But why? Why have today's social democrats not exploited the revisionist phase to
\end{abstract}


adopt a modern left-wing differentia specifica - a programmatic stance that is closer to the social democratic tradition and, when it comes to Europe, one more oriented towards a 'social Europe'?

The aim of this chapter is to integrate the issue of social democratic programmatic identity into the new framework constituted by the European Union. Europe is undergoing a major upheaval and, at the same time, a gentle, slow and silent institutional revolution. And just as parties have historically developed in the wake of major institutional changes (e.g. the advent of universal suffrage or the parliamentarisation of formerly authoritarian states), so today the unprecedented character of the EU has a significant impact on party phenomena and party conflict (Magnette 2001: 58). How does the European framework, particularly its institutional aspects, influence the role and dynamics of political parties (and partisan families)? What are its consequences for the programmatic development and, more generally, the physiognomy and tradition of social democracy? Does the institutional and political system of the EU operate as an obstacle to the resocial democratisation of social democracy's programmatic options?

The treatment of these questions will be macroscopic, the aim being to outline a broad framework of influences and developments, and not to highlight national specificities and variations.

The argument developed here involves three points:

1 The multiplicity of power centres of European governance, the conservative logic of the EU institutional architecture and the inability of parties to find a central guiding role in the overall institutional set-up create a huge problem in relation to collective action and coordination for those aspiring to a strategy of policy or regime change in the EU. Social democratic parties are the most affected by institutional developments, because reformist parties are confronted head on by the 'conservative' character of the European institutions.

2 The extraordinary strengthening of the EU (from 1985 until the end of the 1990s) changed the balance of power between the 'Brussels complex' and the member states, thus further increasing the influence of the conservative EU institutional system. This strengthening has functioned as a double institutional trap for the future: first, by gridlocking the neoliberal logic at the EU level and, second, by the weakening of national institutions and the associated difficulty in countering neo-liberal logic at the national level. Social democrats have found themselves in a nonconjunctural position of ideological inferiority both within the EU system and at the national level.

3 Overall, the EU strengthens the modern aspects of the social democratic profile, but it also contributes to the decline of its historical components. 
With respect to social democratic identity, the EU assumes the role of both an amplifier and an obstacle: it is a factor that contributes to the consolidation and deepening of the great identity change of social democracy and, at the same time, an obstacle to the re-social democratisation of its programmatic options.

\section{The 'Europe' factor and parties: the weakening of a central institution of political modernity}

\section{A fragmented system of powers}

A specific feature of the EU institutional architecture is the lack of a clearcut separation of competences between the Union and the member states and among the Union's central institutions (Bartolini 2006; Chryssochoou 2005: 35). Decisions, within this 'non-state polity', are not made by a dominant organ but instead derive from negotiations between the three pillars of the institutional triangle (Commission, Council, Parliament), on the one hand, and from negotiations between the twenty-seven member states, on the other. Although the European Council has become, in the process, the key motor of integration - also attracting, which is politically important, 'the spotlight of media and public attention' (Tsoukalis 2005) - the Union remains a regime based on continual negotiation between the three pillars, 'none of which manages to monopolize the leadership functions' (Magnette 2005: 65). The consequence of the multiplicity of power centres and the superimposition of decision-making levels is that the EU 'realises a confusion of powers that none of its states would tolerate for itself' (Alliès 2005: 173). The EU suffers from a lack of political leadership (Hix 2006: 13): it is a 'leaderless' superpower.

If we turn from the institutional level of the EU in the strict sense to a more general examination of the power structure in Europe (comprising, in addition to EU institutions, the member states and the distribution of powers at national level), if we thus pass from the EU as institutional phenomenon to the macro-institutional reality of European public powers, the image of fragmentation becomes even more pronounced. The distribution of power centres - the Council, the Commission, the European Parliament, the European Central Bank, the twenty-seven national governments and administrations, the strengthened local administrations and the independent national or European authorities - is such that the overall cohesion of the system of power is weak. In this 'multilevel governance' no established organ and no official or unofficial administration really controls public authority. In fact, there is no single central public authority. In sum, European 'multilevel governance' (conceived as a single, unique power constellation, operating both at the national and the European level) is 
profoundly segmented, without a dominant body (an institution) and without a dominant actor (a state or coalition of states, a political family or coalition of political families). The 'framework of sovereignty' within the macrosystem 'Europe' - compared with the model of national sovereignty - is seriously lacking in focus, cohesion and clarity.

This broad redeployment of competences and powers, which has occurred on account of the EU and in the framework of its construction, calls into question two closely related aspects of party activity and influence: (a) the problem-solving capacity of the parties, whose ability to harmonise the institutional system - and, hence, to govern efficiently - is diminished; and (b) the centrality of parties in the political system.

\section{A political macro-system without a party coordinator}

Historically, one of the important activities of political parties was the harmonisation of relations between different institutions within political systems. Systemic integration, according to Stefano Bartolini, refers to the ability of parties to harmonise and coordinate relations between different 'institutional orders' within complex political systems: parliamentary assemblies, majorities, government coalitions, executives, ministerial bureaucracies, local authorities, and the judicial branch (Bartolini 2005b: 2). Parties - and parties alone - have prevented the Balkanisation of representation and the autonomisation of subsystems within national political systems (by controlling governments and parliaments, by their ability to discipline governmental and parliamentary coalitions, by a degree of control over administration and local political personnel, even - sometimes - by controlling certain major interest groups) (see Bartolini 2005b: 17). Thus, institutional harmonisation and government is one of the two main contributions of political parties to modern politics (the other being the activity of representation). ${ }^{2}$ The partisan character of institutional harmonisation and government/administration was a specific trait of politics in Europe and contributed to the transition from classical parliamentarianism to party democracy.

At the present time, a fundamental institutional dissymmetry - and a major institutional novelty - distinguishes the new state of powers in Europe. In the twenty-seven states, the system of party government remains dominant and the national political capacity of parties, although reduced, is still important. By contrast, at the EU level the system of party government does not really exist and the European political capacity of parties (i.e. their ability to influence decisions within the EU) is not - or not yet - really proven.

In fact, in the absence of a European parliamentarian or presidential system and, also, in the absence of partisan competition for executive office, Euro-parties exert neither the function of government (a central 
aspect of which is institutional and policy harmonisation) nor the function of political representation. Euro-parties remain, despite their clear reinforcement (mainly since the 1990s), essentially weak structures, an instance of 'second-order parties' (Heidar 2003: 3), hardly likely to function as a true political force in the near future. Moreover, this timidly rising actor (Bardi 2004) in the EU political system assumes neither the role of 'spokesperson' of the system of power in Europe nor the role of 'regulator of meaning', responsible for 'conveying to the collectivity it represents an image of coherence and cohesion' (Smith 2004: 68). At root, the European Union does not constitute a suitable framework for the exercise of partisan authority: 'in its deepest characteristics', Paul Magnette has written, 'the European community model rejects the classical form of the political party' (Magnette 2001: 63). Thus, the reduction of partisan influence in national space remains uncompensated, or without equivalent compensation, at the supranational level (cf. Mair 2005: 14).

Given this fundamental institutional divergence (party government at national level and its absence at a specifically European level),$^{3}$ the parties can no longer ensure the cohesion of power centres and are no longer identified, as they used to be, with public authority; or, to be more precise: if they take responsibility for the cohesion of power centres at a national level, they do not ensure this cohesion in the system as a whole (for the 'Brussels complex', which is not governed by parties, now represents a crucial component in the network of European executives). Weakened institutional leaders, though nevertheless still leaders at a national level, but without a clearly defined role at EU level, political parties have lost a significant proportion of their erstwhile influence. At the same time, they have lost most of their credibility, becoming today 'the least trusted of any of the major political institutions in contemporary democracy' (Mair 2008: 330). Parties matter less as problem-solving structures and, because of this, they matter less as representative vehicles. ${ }^{4}$

Of course, political parties are firmly rooted in European representative systems. Parties - in particular, major parties with a governmental vocation - are ubiquitous: they direct the national state, they dominate national parliaments, they control local authorities and the European Parliament, they are present in the European Council, and are even indirectly present in the Commission. At first sight, then, the influence of parties remains strong.

However, depending on the particular case, their strong role (in fact, absolute domination) in an institution (e.g. national parliaments, national governments, the European Parliament) is reduced either by their strong but non-compact presence (divided into twenty-seven parts) within a different one (European Council), or by their feeble and indirect power elsewhere (e.g. the Commission), or by an absence of influence in other institutions (e.g. non- 
majoritarian institutions like the European Central Bank or, at a national level, independent authorities). In addition, this influence is diminished by competition between the different power centres, national and European. Therefore, even though parties have not lost in presence, they have lost in political centrality and, notably, they have lost their capacity for institutional coordination: they ensure the cohesion of institutions that count (and hence the cohesion of policies) to a much lesser extent than they did in the past.

As a consequence, the European macro-system is a system without a party coordinator. No partisan family simultaneously controls national governments, the European Council, the Commission and the European Parliament; and no political family is likely to do so in the future. The possibility of having a Commission-Parliament-Council of the same political colour for a sustained period is 'simply not realistic', stresses Stefano Bartolini (2006: 40). At the present state of European affairs, there is no way for any political family to harmonise and manage the fragmented institutional apparatus of European governance. Furthermore, there is no way for any political family to be put together and act as a truly European force (the actions of a party unfold mainly at the national level and are punished or rewarded by the popular vote in national elections).

If, ultimately, the EU poses a 'role' problem for each and every party family, the same holds true for social democracy. Only in its case the problem is even more pronounced. Control of the market and capitalism entails - actually, it has always required - both a strong central authority and a strong political force capable of pursuing policies that are different from the market's. Nowadays, in the framework of multilevel and multisites European governance, neither prerequisite is met: no central public authority exists and a powerful transnational social democracy capable of managing European governance is not easy to set up.

Social democratic parties are seriously affected by the fragmentation of European governance and their proper (albeit natural) incapacity for effective coordination of their European action. In reality, they are seriously affected by the deep reach and scope of European integration.

\section{A 'conservative' political system}

The EU, as Simon Hix argues, 'is perhaps more consensus-oriented in its design than any political system in the history of modern government' (Hix 2006: 12). In consequence, it is a cumbersome system in its modus operandi, one largely based on concessions and a logic of compromise and small steps. The EU is a profoundly conservative system, in the sense that it 'protects' the units (the states) that make it up and does not easily revisit institutional and political decisions it has taken.

First of all, changes and adaptations in the EU invariably occur on the 
margins, without a fundamental challenge to initial options and ways of operating (gradualism is part of the acquis communautaire). Second, the whole community culture is based on the idea that no institution is ruled by majority logic or a stable coalition (decisions being the result of an ongoing process of compromise, in which partisan logics play a limited role) (Costa 2004: 282).

These two logics (gradualism on the one hand, compromises without parties, or compromises in which the role of parties is secondary, on the other) are central and represent the apex of the acquis communautaire. As described above, the European system, as Tsoukalis has appositely written, 'carries a heavy historical load, which discriminates against newcomers and new political majorities' (Tsoukalis 2005). It also functions at the expense of non-conformist institutional initiatives and daring political coups. The EU's constitutional mandate 'changes through evolution, not revolution' (Moravcsik 2001: 4). The same applies to the policies adopted in different areas: initial policy options tend to persist and shape subsequent policy-making (Johansson and Raunio 2005: 518-19). Once a policy has been adopted, the checks and balances of the EU make it very difficult for this policy to change ('institutional gridlock') (Hix 2006: 8).

In reality, everything in the EU changes slowly, through evolution, not revolution. The micro-mechanisms - the 'nuts and bolts, cogs and wheels' $-{ }^{5}$ of the European Union do not favour strong (or weak) ${ }^{6}$ political reformism at an EU level and make a reinstitution of European politics difficult. In this system with segmented powers and competences, with twenty-seven actor-countries, with political parties that are very weak (at the European level) or weakened (at the national level), and without a dominant actor or institution - in this system where the logic of consensus or grand coalition rules, it is very difficult to produce a new master narrative and a new 'frame of action' (Pappas 2006: 19). Political leadership and strategic vision do not easily come out of such a system (Tsoukalis 2005).

The 'conservative' character of the system is further encouraged by the marked tendency to depoliticise sensitive questions, so as to avoid decisionmaking blockages. ${ }^{7}$ The objective of 'keeping the engine ticking over', in order to maintain a cooperative dynamic, is the key - the real cause of the conservatism (in the sense not of left-right divisions, let us repeat, but of an aversion to change). It is superfluous to add that tendencies to regime preservation have been accentuated by successive enlargements - especially the 'big bang' expansion of 2004.

Basically, with the undermining of the 'strong state' model, with the strengthening of the civil service and the experts at the European level (and to a certain extent at the national level), "the role of political parties as the main producers of policy-oriented ideology and ideas is challenged' 
(Lindvall and Rothstein 2006: 61; quoted in Mair 2008: 228). The ideological and programmatic renewal of social democracy, and of any 'responsible' force operating within such a system, is not encouraged. By contrast, programmatic convergence and the weakening of political cleavages find a more fertile terrain.

That said, Europe should not be thought as an infernal machine that devours its own children. The 'conservative' character (in the sense defined above) of the EU regime and the culture of gradual change have not been established out of perversity. The multinational and multi-state character of the regime requires barriers to prevent one group of countries or actors dominating another (cf. Lord 2001: 43; Hix 2006: 13). To co-administer sovereignties in a pragmatic and moderate fashion, in this polycentric polity where sovereignty is 'participatory' and 'fragmented', is a question of survival for the regime.

Thus, if ideological parti pris explains the liberal character of the EU's economic options, it only partially explains the culture of moderation, the gradualism, the pragmatism of its institutions, the complexity of its procedures, the multiplicity of its power centres, and the superimposition of levels of decision-making or the weakness of the Euro-parties. The European Union is the product of a mechanics of forces and a set of structures and then, but only then, the product of an ideological parti pris. The fragmentation of the framework of sovereignty, and the institutional and political culture that accompanies it, are not the result of a 'bad' strategy or a non-strategic conception - and construction - of the European system (any action, by a state, party, or any other agent, contains a strategic calculation). It is the result not of a process 'without an actor', but of a large number of processes with several actors who acted - and are still acting - at local, national or specifically European levels. The actors are the national states, European authorities, parties (national and trans-national), interest groups, lobbies, and even the 'people' (for example, the 'no' votes in the French (2005), Dutch (2005) and Irish (2008) referendums directly influenced the structure or the dynamic of this 'framework of sovereignty'). These actors, who negotiate Europe and fashion Europe, have ended up making this 'conservative' Europe - a consensual elitist system, one without a central core of authority and without a single, unique centre of power. It remains the case that this internally fragmented system, like any system, produces results.

\section{The 'Europe' factor and social democratic identity}

Conservative system, coordination problem and social democracy

The segmentation of competences and multiplicity of power centres in European multilevel governance, as well as the structural inability of 
parties to find a central guiding role in the overall institutional set-up, create a formidable problem of collective action and coordination for all those aspiring to a strategy of change and ruptures. The institutional reality of the EU is a sizeable obstacle in the path of all actors (national states, left-wing parties, populist right-wing parties, trade unions, pro- or anti-European associations, anti-globalisation or alternative globalisation movements) who aspire to change the EU's economic policy and institutional architecture. This problem of collective action is doubly strategic: there is no Winter Palace to occupy or surround in the European political system; there is no royal road for prompting and coordinating the mobilisation of actors with highly diverse sensibilities, cultures and interests.

Naturally, this problem of collective action and coordination is common to all political parties and families. Nevertheless, it particularly affects social democratic parties (and, more generally, left-wing parties): parties that aim to correct - or change - the dominant economic paradigm are more in need of strong institutional (and societal) resources. This problem affects more specifically the social democratic parties, because it is mainly they who, as essentially governmental parties, are confronted head on with the 'conservative' character of the European institutions. It is they who participate in the Council and contribute to the formation of the majorities in the Parliament; it is also they who appoint some of the Commissioners. By contrast, the smaller parties of the radical left (or the Green parties), as parties of opposition, are the ones that benefit electorally from the conservatism of the system. Conservatism, forcing the social democrats to adopt pragmatist positions and thus to convergence with the centre-right parties, widens the competitive space for outsiders and new parties (see Richard Luther and Muller-Rommel 2002: 334).

Everything that has been said so far confronts socialists or at least those who wish - assuming they do wish - to 'change' Europe, with a very delicate problem: how to change a system that is 'closed' to the logic of change, without blocking it? How to be radical (in the sense of promoting new policies and new operating frameworks) in a system that, by its very nature (complex and cumbersome decision-making mechanism, twentyseven players-countries), is easily weakened under the pressure of change? And, consequently, how to change European policies without breaking the European 'machine' that generates them? This is what all those who aspire to reform the economic policy and institutional architecture of the $\mathrm{EU}$ - and the actual direction of the reforms is of little moment here - come up against.

Social democracy is not obliged to respect what has gone before (if it does, it will have difficulty affirming its social democratic identity). However, it cannot ignore it (if it does, it ceases to be 'European' in the sense of searching 
for solutions at the EU level). This condemns it to treading a very thin line; and, often, to taking refuge in rhetoric (e.g. the rhetoric of 'social Europe').

Basically, the adoption of a more aggressive approach (institutional and/ or political) by socialists would be liable to explode the largely 'consensual' physiognomy of the EU. It would be liable to affect its essence: compromise, the step-by-step approach, marginal adjustments.

Here, Bartolini's analysis is wholly apposite. Bartolini formulates the issue as follows:

If a political mandate emerged from more open and partisan debates in the Council, Commission, and Parliament - say, for example, a mandate involving expansionary monetary policies, European social welfare minima, active occupational or fiscal policies, or a radical alteration of agricultural policy could it be implemented? The answer is NO. Such a political mandate would be frustrated by the autonomy of the European Central Bank, by the case law of the ECJ, by the blocking vetoes in the Council. (Bartolini 2006: 39)

In truth, this type of mandate is impossible today because of socialist divisions. It would be difficult for social democrats to formulate or implement a set - this or any other - of left-wing initiatives: first of all, because there are parties belonging to the social democratic family that would block the process in its early stages (e.g. in the PES) and next because, somewhere in the system's many cogs (the most plausible being the ECJ or the Council), such initiatives would be halted. They would not be in accordance with European policy style - that is, the selection of issues for the political agenda and the standard operating procedures for handling them.

\section{Preventive renunciation: the exorbitant cost of divisions, the liability of grand coalitions}

Two political examples, presented briefly here, may illustrate the problem of collective action confronted or, rather, avoided by the social democrats. The first example relates to the 'opportunity of the 1990s' and the second to the perennial problem of a 'social Europe'. In both cases, the failure of the social democrats should be attributed, in addition to ideological factors, to: (a) the consensual or almost consensual character of the system; and (b) the disagreements and divisions that were evidenced within the social democratic family.

The 'lost' opportunity of the $1990 \mathrm{~s}$

The inability of social democracy in the late 1990s, when twelve out of the fifteen European states elected leftist governments, to produce more explicit left-wing policies and to exploit this politically unique-even ifbrief-moment of electoral convergence illustrates the two factors mentioned above.

A plausible explanation for this failure is a lack of will: 'they didn't 
want to [produce more left-wing policies] because they weren't really left anymore' (Allen 2002). In a sense, the 'forced' resignation of Oscar Lafontaine, whose expansionary economic proposals ran counter to the economic mainstream, illustrated this 'lack of will' on the part of social democratic leaderships (or of some of them) faced with a change of orientation in economic policy (Moschonas, 2002: 265-8). However, European social democrats had at the time no common programme for economic regulation at EU level (Notermans 2001: 269; Ross 2009). Beyond the presumed 'lack of will', the economic strategies of the twelve socialist governments and the interest constellations in the member states have been, from the very beginning, too heterogeneous for effective coordination. Thus, the cumulative effects of both lack of will (for some) and national differences $(\text { for all })^{8}$ produced - in a system with high institutional hurdles for any policy reorientation - a problem of coordination. Naturally, the coordination problem, or anticipation of such a problem, multiplied the effects of the absence of will and of the divisions inside the social democratic family. This generated uncertainty and indecision regarding which policies to pursue and what kind of orientation to take. Divisions and the EU institutional configuration weakened any realistic prospect of success.

Without a realistic prospect of success, actors always prefer the status quo: the option of 'change' in this case seems like a 'hopeless vain struggle', a net cost without a reasonable anticipation of profit. At the time, for social democratic leaders, given the institutional barriers and the disparate positions of socialist governments, supporting the status quo was a rational choice.

Certainly, according to Christopher Allen, the 'fundamental failure of imagination' was the main factor behind social democratic inaction (Allen 2002). Ideas and imagination, however, are not constraint free. European institutional arrangements (the scale of majorities required) and social democratic divisions, by lowering expectations, inhibited imagination and inventiveness. Diminished expectations impeded the production of "creative political entrepreneurs'. Overall, the coordination problem prevented socialists from supporting more dirigiste and expansionary policies at the European level. If the challenge of the late 1990s was great, the opportunity was less 'historical' than it appeared.

\section{European social policy}

The strategy of the 1980s erected a structural asymmetry between market integration and positive welfare integration, hence endowing the EU with an institutional and legal framework in aid of 'Market Europe' and at the expense of 'Social Europe' (Hansen 2005: 47-9). In fact, compared to national political systems, the capacity of the EU to redistribute resources 
between individuals, groups, regions or states through taxation and public spending is limited. The EU has no real fiscal powers and very few means for implementing redistributive policies. ${ }^{9}$ The residual character of the EU's social policy, besides the powerful market-making bias of the EU, is due to the differences in social philosophy between the member states (the "clash of national interests'), but also to the extreme heterogeneity of the national welfare states, which renders the construction of a genuine European welfare state extremely difficult (Majone 1996).

This problem of collective action and coordination became evident with the pre-election appeal (in the 2004 European elections) for a 'Social Europe' by certain socialist leaders (including Rasmussen, head of the PES, and Antonio Guterres, President at the time of the Socialist International). Labour's third way policies and the 'Agenda 2010' of the SPD (see Chapters 1, 2 and 7 in this book) did not allow Blair and Schröder to give their endorsements to such an initiative. For their part, the Scandinavian social democrats, who continue to represent a 'social' version of social democracy, were not ready to accept the harmonisation by Brussels of national regulations on social issues - something that could imperil their welfare states. As national parties were moving in different, even opposite, directions, the constellation of political interests and approaches within the PES made impossible the construction of a majority coalition to promulgate a genuinely common social programme.

In general, due partly to socialist divisions and, to a greater extent, to the interest constellations within the member states (the systems of national security being 'too heterogeneous'), concrete proposals for promoting a social Europe are rare, even 'undesirable' (Notermans 2001: 269). Social Europe has become a 'shibboleth' (Bellec 2005: 275) without any impact - other than rhetorical - on the political priorities of the national socialist parties or the PES. The absence of a substantive social democratic output on such a central matter for the social democratic political and ideological profile illustrates the formidable problem of coordination and collective action in a supranational framework. It is important to notice that the problem of coordination of 'Social Europe' has been accentuated by successive enlargements. Distrust of any development of a 'Social Europe' on the part of social democratic parties from central and eastern Europe presents a characteristic example of how the new countries could strengthen divisions within the social democratic family.

So, to the question: why has contemporary social democracy's great capacity for adaptation not produced a left-wing differentia specifica, a programmatic stance more oriented towards Social Europe and a left-wing style of market regulation? The institutional structure and operational logic of the EU on the one hand, and differences in economic and social philosophy 
within the socialist family on the other, offer a partial answer. Socialist divisions are the common denominator underlying, notwithstanding some minor successes, the ideological inertia of the socialist family (Ross 2009).

Yet divisions are nothing new in the long social democratic tradition in Europe; they are a constant. In a sense, European socialism has never been as unified as it is today. In the past, the distance between left- and rightwing alternatives within the social democratic family was greater than it is today, and the contrasts were noticeably stronger. In a world without the EU, these divisions, which are perfectly natural and ultimately weak, would have simply constituted the basis for different national roads. However, we live in a world with the EU. Accordingly, these divisions, when transferred to the European level, entail - as managed by the EU institutional apparatus and mediatised by it - the political paralysis of the socialist family. Divisions, because of the EU, because of the high institutional hurdles for any policy reorientation, are more important today than, let us say, in the 1960s or 1930s. The EU compels member states or national parties (in the Europarties or in the European Parliament) either to construct grand coalitions or to abandon their policy. In reality, social democratic disagreements on the institutional and economic construction of Europe lead to indecision or to the preventive abandonment of any 'transformational' aim outside the mainstream. Disagreements and divisions undermine, above the ordinary, partisan control of the Union's central institutions. The cost of divisions has become exorbitant.

\section{Conservative system, ideational spillover and national politics}

The institutional (and economic) logic of the Union does not have only European consequences, restricted to the level of the EU. It has an important influence on the policy proposals and governmental action of national parties and in this respect defines largely the content of reformism at a national level. The political and programmatic horizon being considerably narrowed, any kind of national social democratic reformism which appears 'disrespectful' of the EU's options seems eccentric (and rightly so!); the attitude of Laurent Fabius in favor of the 'no' vote in the French referendum (2005) is a case in point. The claim by politicians that 'Brussels made me do it' is in perfect accord with the institutional and political pragmatism dominating the European political system. It is also in conformity with the perception that Europe sets important limits on any programmatic alternative and policy innovation (see Ladrech 2000: 31). National party elites anticipate what is possible and what is not. Here too, as in the case of the Brussels elites, the logic of preventive renunciation cuts deep. Programmatic elites (party or ministerial, national or European), specialising in the production of policy-oriented ideas, adapt to the European political style. ${ }^{10}$ 
As long as a significant number of decisions are taken in Brussels, as long as the argument 'it is the EU that decided' corresponds to the reality of decision-making - and is not merely an alibi on the part of national elites it is rather risky (and often, pointless) to pursue 'extraordinary politics' at the national level. The incentives and constraints imposed by the European Union, as well as the expectations that form around them, have an important impact on national policies. ${ }^{11}$ By a kind of 'ideational spill-over' (Thomas Risse, quoted by Hooghe and Marks 2008: 120), Brussels gradualism spreads to the totality of national established political forces.

\section{A double institutional trap and social democratic identity}

In the current state of European affairs, the exercise of national sovereignty is impeded by political rules jointly decided within the EU, while, at the same time, in the name of national sovereignty a federal sovereignty has been prevented from emerging (Fitoussi 2005: 99). ${ }^{12}$ To paraphrase and extend a conclusion of Simon Lightfoot's regarding the PES (Lightfoot 2005: 147), the present situation falls between two stools: the EU is neither a truly supranational entity nor does it allow the member states to pursue a national road. Thus, the EU functions as a relatively strong impediment and as a relatively weak incentive.

How has this developed, and how is this process linked to the neoliberalisation of Europe (and of social democracy)? Historically, European integration was conceived and developed on the basis of economic principles which can be described as 'liberal', even if [these principles] 'were not apparent for the first two decades', even if they left 'enough space for governments to pursue social democratic policies' (McGowan 2001: 75, 78 ), at least until the middle of the 1980s. In the 1980s and 1990s something important happened at the heart of Europe that was comparable in its impact to the creation of the Common Market in 1957. The Single Market, the enlargement of the scope of liberalisation in new areas, the reinforcement of majority voting in the Council of Ministers, the more active role and the new dynamics of the Court and Commission (notably under Jacques Delors), the strengthening of the European Parliament, the foundation of the European Central Bank and, more generally, the impact of the Maastricht Treaty, took integration to a new level (Ferenczi 2008: 56-62; Ross 2009). It was something of a 'second foundation' of the European community (Ryner 2007: 8).

The revitalisation of European integration during the 1980s and $1990 \mathrm{~s}^{13}$ had and continues to have large-scale effects on both Europe and social democratic parties. There are three reasons for this: (a) national policy is severely constrained in its problem-solving capacity (and national parties in their influence), whereas the EU has become strong, but not sufficiently 
strong to pursue a genuinely supranational politics; (b) the new balance of forces between the 'Brussels complex' and the member states increased the impact of the conservative EU institutional system (EU conservatism is powerful only in the case of offering no escape route at the national level); (c) as a result, EU liberal policies have been constraining national social democratic options more than vice versa (McGowan 2001: 85).

Given this new framework, the 'Brussels complex', which has passed from a 'primitive site of collective government' to a densely institutionalised system of interrelationships (Caporaso and Sweet 2001: 221), has functioned as a double institutional trap for the future: first, by the institutional gridlocking of neo-liberal logic and the difficulty in countering liberal solutions at the European level; and, second, by the weakening of national institutions and parties and the associated difficulty in countering neo-liberal logic at the national level. Thus, what may have been initially an institutional event may produce enduring ideological results. The blind mechanics of strong complementarity and mutual neutralisation between European and national institutions (a product of the reforms of the 1980s and 1990s) made virtually inevitable the almost 'unconditional surrender' to liberal solutions. As a result, the new 'asymmetric dynamic' (to use McGowan's term) between social democracy and European integration (with the EU's liberal policies contributing to a reorientation of national social democratic options more than vice versa) was not only the consequence of liberal ideas becoming locked in at the EU level (McGowan 2001: 85); it was also the result of the weakening of parties and institutions at the national level, which made this locking in more solid and powerful. This double trap gave liberal economic solutions a long-term advantage.

The significance of the events of this period (the 1980s and 1990s) has been invariably neglected or has only been appreciated in retrospect. The 'second project of integration' (Ryner 2007) was a turning point in the history of Europe. It also was a key moment in the history of social democracy over the last thirty years. Elsewhere we have referred to the major change in contemporary social democracy as a 'great transformation' (Moschonas 2002). Today, ex-post, we believe that in this great transformation there was a key period of extension and consolidation when disorderly effervescence took on a more stable structure, more depth and solidity. This period and the extraordinary strengthening of the EU from 1985 until the end of the 1990s are intimately linked (in part chronologically, more so qualitatively). George Ross perceptively shows this critical influence: 'The EU took the lead in enjoining its members to conform to a new world where Keynesianism was anachronistic and welfare states and industrial relations systems needed serious reform ... These were the European conditions in which "lefts" would become "center-lefts" (Ross 
2009). In essence, the EU contributed a great deal to the greater political depth and solidity of social democracy's new profile. It exerted powerful, often indirect and silent, influence, both as support and as constraint, on the new social democratic programmatic stance. With the second project of integration, social democrats have found themselves in a non-conjunctural position of ideological inferiority in European political space. They have lost ground as well as a great part of their programmatic freedom of manoeuvre. Social democracy exhibited strong signs of programmatic destabilisation and exhaustion.

\section{Trapped in Europe? The EU and the identity dilemma of social democracy} If socio-economic and cultural evolution do not represent 'a particular drama for social democracy' in the sense that they affect all political parties to some degree (Callaghan 2005: 190), European integration affects social democratic parties more than conservative, liberal, Left radical, or rightwing populist parties (cf. Ladrech 2000: 73). The EU, in its current form, is not the ideal place for socialist ideologies, moderate or radical. It is not supportive of more economic regulation, a more encompassing welfare state, or Keynesian deficit spending. At root, the EU is undermining three of the most essential elements in the formation of social democracy's historical identity: (a) the state-oriented culture of social democratic appeal; (b) welfare politics and, therefore, the link with the working class; (c) the broad primacy of politics orientation.

In particular, fragmentation and segmentation of decision-making within the macro-system 'Europe' do not fit the traditional social democratic 'love affair with centralized control' (Sassoon 2006: 24). Most importantly, the fact that the EU 'seeks to promote wider and deeper markets without establishing a correspondingly full range of compensating and counterbalancing social and regulatory policies' (Moravcsik and Sangiovanni [n.d.]: 1 ) is at odds with the principle of welfarism, a central ideological pillar of modern social democratic culture. Moreover, the EU's conservative institutional logic and the decline in the role played by political parties in generating policy-oriented ideas are also at odds with the 'belief' in the primacy of politics (over economics) that, historically, has underpinned social democratic action (Berman 2006) and has made social democracy a transformative political force. Today, the mechanisms of the Brussels system impede social democratic action politically, through collectively decided rules, and not through economic constraints (Fitoussi 2005: 99). As a result, social democratic parties have to face not only 'markets against politics' but also 'institutions against politics': their policies are conditioned not only by economics ('globalisation as constraint'), but also by politics (the EU as constraint). This unprecedented situation, without any real equivalent in 
the national state, constitutes a 'hidden' aspect of Europeanisation or (to borrow Colin Hay's term) 'EU-isation' (Hay 2002); and it partially explains the extreme moderation of social democratic programmatic options as well as the ideological and programmatic convergence of government parties of the right and left. Social democratic parties 'as carriers of ideology' (Berman 2006: 204) are under extreme pressure.

Given these influences, it is scarcely surprising that current popular anxieties and growing Euro-scepticism remain without an effective political response on the left. ${ }^{14}$ The European programmatic stance of social democrats, bereft of alternative economic ideas, incapable of articulating Europewide political alternatives, is scarcely capable - despite the revisionist fever of the 1990s - of structuring the politics of the European Union differently. ${ }^{15}$ Moreover, sociological analysis of support for European integration yields a picture of a social democracy incapable of creating a genuine popular Europeanism (see Cautrès and Grunberg 2008). The Euro-scepticism of the lower classes and the lack of a European social policy, closely related to each other, are traumatising the social democratic profile and, in part, the electoral dynamics of social democratic parties (Grunberg and Moschonas 2005). Europe is weakening the sociological specificity of social democracy and is becoming an additional factor in its change of identity.

However, if the EU is a factor of ideological disarray for social democrats, it is also a factor of modernisation. It is an open window on the world and a mechanism, though doubtless a cumbersome, slow and conservative one, that has gradually transformed the image of the continent. As the territorial nation-state loses control over national economies and social democracy faces challenges it cannot easily meet, the EU becomes a polity - and a player - that counts for more in the new complex environment. It is also a mechanism that allows social democracy, which has become proEuropean, to connect better with the salaried and educated middle strata of the population. Social democracy's commitment to European integration reinforces its link with these strata, strongly 'attached' to cultural liberalism and post-materialist values, as well as with the segment of the population frequently considered to be the 'integration winners', who are attached to the dynamic of cosmopolitan modernisation. This attachment sustains electorally the modernised aspects of the social democratic profile. It is worth noting that the programmatic social democratic renewal on cultural liberalism as well as on ecological matters (Callaghan 2006) has been remarkable and, at least in some countries, it is now the only programmatic area where social democracy clearly dominates the centre-right. The social democratic electoral gains among educated middle strata are largely explained by the social democratic domination in the domain of cultural liberalism. Europe reinforces this tendency. 
Overall, the EU strengthens the modern aspects of the social democratic profile while it contributes to the decline of its historical components, which are part of the profoundest political specificity of centre-left parties. The EU, both as a polity in the making and as a market-oriented entity, weakens the ideological distinctiveness of contemporary social democratic parties - already undermined by such factors as the economic slowdown, the financial limits of Keynesianism, globalisation, change in the model of economic production, and catch-all politics. The EU is an autonomous cause of change. It reinforces trends that are already operative and account for the redefinition of historical social democratic identity (programmatic, but also sociological). The EU assumes the role of both an amplifier and an obstacle: it is a factor that contributes to the consolidation and deepening of the great identity change of social democracy and, at the same time, an obstacle to the re-social democratisation of its programmatic options. ${ }^{16}$

So why has contemporary social democracy's great capacity for adaptation not produced a left-wing differentia specifica, an agenda more orientated towards social Europe and a left-wing style of market regulation? The EU offers a partial answer that invokes both the institutional structure and operational logic of the EU system, as well as the differences in economic and social philosophy within the socialist family. The great programmatic flexibility of contemporary social democratic parties, which has allowed them to produce a large number of new ideas and policy proposals at the national level, is at bottom a flexibility respectful of the basic economic orientations of the Brussels mainstream. Not to respect this mainstream would be to block or destabilise the EU (and 'explode' the ideological and electoral stability of the social democratic parties, a majority of which have made Europe a fundamental aspect of their new ideological profile). To respect it is to further destabilise social democracy's historical identity. There is no easy solution to this dilemma, which is both a policy dilemma and a problem of identity.

Ironically, trapped in this dilemma is the new Europeanised social democracy, a social democracy that is no longer trailing behind integration and is 're-promoting traditional social democratic intervention at the European level' (Bale 2005: 18). If a social democratic strategy of a leftwing re-regulation passes through Europe, the EU renders this strategy more difficult to achieve.

\section{Afterword: social democracy's dilemma and the future}

Are the constraints upon social democracy primarily a result of globalisation or of European integration? Today, perhaps, there is no point trying to identify which factor came first, and which factor prevailed in the 
neo-liberalisation of politics at a European level and beyond. In general, the thesis that neo-liberalism initially came to dominance as a result of the collapse of the post-war boom and the limitations of Keynesianism is fairly convincing (Lavelle 2008). A neo-liberal turn occurred well before the Maastricht Treaty and was not restricted to Europe (in this respect, Australia and New Zealand are two good examples). The neo-liberalisation of social democracy pre-dates the European Union (Lavelle 2008: 23-4, 121, 151 and Chapter 1 in this collection). Even so, the Single European Market and implementation of the Maastricht Treaty converged to create a specific trend in Europe, an accelerated and focused adjustment that made the neo-liberalisation of European social democracy deeper and more coherent. As Francis McGowan wrote, 'European integration involves member states committing themselves to a much more robust set of rules than those which might be regarded as framing globalization (WTO, IMF, etc.). Moreover, in the detail of reforms, the imprint of the EU is much clearer than that of global pressures' (2001: 98).

It is not impossible that there will be a change of direction in European politics. According to Gary Marks, as European integration has been transformed from a market-creating and market-enabling process to a polity-making process, the focus of debate will probably shift from creating a market to regulating it (Marks 2004: 258). Of course, Europeanisation is a 'matrix of powerful pressures not always pulling in the same direction' (Hanley 2002: 479). Thus, in the future we will probably see two parallel drives operating simultaneously: one pushing the EU to integrate itself further into the paradigm of economic liberalism; and another one adjusting this paradigm by instilling into it elements derived from a largely nonliberal perspective. In a sense, this process, as 'the needs for both regulation and social protection are increasingly understood' (Shaw 2001: 24), is already under way. In a system, however, in which 'the standardization of the internal market regulation and the centralization of the jurisdictional activities have developed before and without the centralization of political power ... and the creation of political agencies' (Bartolini 2005a: 247), any such correction will rather occur on the margins, without fundamentally altering methods of operation.

Any radical correction would necessitate revising some of the most deeply rooted elements of the workings of the EU, requiring all, or almost all, of the major European players to sign up. This would mean formulating a new ideological mainstream and creating a new 'grand coalition' within the EU. The 'secret combination' of EU operations (segmented powers, high institutional hurdles for any policy reorientation, jurisdictional acquis, a small EU budget, the difficulty of conducting partisan politics, social democratic divisions, and, last but not least, the absence of a distinctively left-wing 
agenda for the EU) makes a social democratic reorientation of the EU difficult to implement. However much socialists and social democrats want a powerful, more left-oriented Europe, ${ }^{17}$ they do not possess the requisite institutional and political means, perhaps not even the ideas, for refocusing integration. Although conducive to bargains, the dilemma of destabilising the EU or further destabilising social democratic identity is here to stay.

The entire history of social democracy, from the Erfurt Programme to the Stockholm School, from Austro-Keynesianism to the more recent achievements of socialists in southern Europe, demonstrates that social democratic parties established themselves as central, majority forces when they took an ideological lead over their right-wing opponents; when they generated or adopted ideas which the latter were not yet ready to accept or implement (such as universal suffrage, the political rights of the working class, the welfare state, Keynesianism, or, more recently, the deepening of democracy and cultural modernisation in southern Europe). Ideas count; this is clearly shown in the history of social democracy.

Institutions count, too. We have tried to show that, in the new European environment, institutions have to be taken into consideration much more than in the past. Institutions without actors, however, explain neither change nor stagnation (cf. Merkel and Petring 2007: 140). Institutions are obstacles or weapons, they do not generate policies by themselves. Today, in the EU, the problem posed for social democrats is that of the primacy of politics in a 'conservative' institutional terrain. How is the ideological and programmatic ascendancy of social democracy to be restored in this difficult terrain? The great issue here is not, as is often claimed, ideological loyalty (social democracy has virtually never been faithful to its ideology) but programmatic innovation: left-wing programmes must be attuned to the needs of a new European stage. Social democracy, which has not long had a pro-European orientation, needs to achieve 'tangible results' (Telo 2005: 129). Such results are even more politically important because the electoral and ideological pressure being put upon social democracy from political parties to its left has increased.

It is however extraordinarily difficult for social democratic parties to achieve 'tangible results' - and to restore their programmatic ascendancy - without effectively coordinating their efforts across national borders. The ineffectiveness, if not the paralysis, of social democratic action in Europe, because of disagreements and poor collaboration, has shown how important transnational cooperation has become for national parties. Programmatic innovation and effective cooperation in a European (and global) context of reduced programmatic autonomy is a puzzle that contemporary social democratic parties are called upon to resolve. As both these targets are difficult to achieve, pessimism is justified. 


\section{Notes}

1 A part of this text was written in French. I wish to thank Gregory Elliott who has translated it into English. I alone, though, am responsible for any weaknesses that remain, especially in those parts of the text that were written directly in English.

2 According to Stefano Bartolini (2005b: 2), "political and systemic integration have been the two main contributions of political parties to modern politics'. I adopt a slightly different terminology here.

3 This dimension is largely neglected by specialists on political parties. More generally, the issue of party government is not the preferred subject of research on parties. Among the small number of exceptions, see the comprehensive study by Peter Mair (2008). Mair shows that party government remains strong, although some of the conditions for its maintenance are slipping away. In this work, Mair, though a researcher who is very familiar with European issues, neglects these divergent institutional realities (party government at national level and its absence at a specifically European level).

4 The impact of Europeanisation (and globalisation) undermines the generally accepted thesis that the partisan 'change' is attributable to an alteration in the balance between the function of representation and the function of governance, in favour of the latter. Today, analysis of the 'crisis' of parties would gain in relevance by switching perspectives: it is the decline in parties' governmental capacity (a deficit of governmental effectiveness) that reduces their social representativeness (a deficit of social support), and thereby deepens the discredit of the party organisations.

5 A formula used in a different context by Jon Elster (quoted in Pappas 2006: 13).

6 These terms are taken from Richard Dunphy, who distinguishes between 'strong' and 'weak' reformism (2004: 5-6).

7 Unquestionably, it is the Commission, more than any other institution that displays a tendency to depoliticise decisions (Alliès 2005: 165).

8 Neue Mitte in Germany and Third Way in Britain, Gauche Plurielle in France.

9 The Common Agricultural Policy (CAP) represents, however, a kind of 'welfare policy for farmers', while the common regional policy represents a welfare policy for territories (Demertzis 2005).

10 The term 'programmatic elites' is taken from William Genieys (2008).

11 For a general and comprehensive survey of the impact of EMU on domestic social models, see Featherstone (2004).

12 'National policy is severely restrained in its problem-solving capacity, while European policy is constrained by the lack of intergovernmental agreement', wrote Fritz Scharpf (1996: 15).

13 Although the majority of European leaders who contributed to the renewal of the European dynamic came from the ranks of the centre-right, the transition from Euro-pessimism to the Euro-euphoria of 1989-99 owes much to French socialists. On the important role of President Mitterrand and Jacques Delors, see the detailed analysis by George Ross (2001 and 2009). 
1481 per cent of workers voted 'no' in the French referendum on 29 May 2005 (see Perrineau 2005: 241-2). This massive negative working-class vote, in a period of decline in working-class culture and political cohesion, indicates the profound frustration among the lower classes in relation to the EU.

15 An aspect of social democratic 'modesty' concerns its political contribution within the EU. The influence of social democracy on the process of European construction and on EU policies is perceptible but 'minimal' (see Ladrech (2003: 112-24); Ladrech (2000); Kulahci (2003); Lightfoot (2006)).

16 In relation to social democratic organisations, the thesis of amplification also seems pertinent in accounting for the strengthening of the role of the party leader and the party elites vis-à-vis the rest of the organisation. Nevertheless, the organisational change induced by European integration has been 'limited and patchy' (Aylott et al. 2007: 208).

17 Despite its neo-liberalisation, social democracy has not turned its back on the logic and politics of solidarity; and it continues to defend left-wing values, albeit redefined (Stjerno, 2004).

\section{References}

Allen, C. S. (2002) 'Social democracy, globalization and governance: why is there no European left program in the EU?', Minda de Gunzburg Center for European Studies, Harvard University.

Alliès, P. (2005) Une Constitution contre la démocratie? (Paris: Climats).

Aylott, N., Morales, L. and Ramiro, L. (2007) 'Some things change, a lot stays the same', in T. Poguntke, N. Aylott, E. Carter, R. Ladrech and R. Luther Kurt (eds), The Europeanization of National Political Parties, Power and Organizational Adaptation (London and New York: Routledge).

Bailey, D. (2005) 'Obfuscation through integration: legitimating 'new' social democracy in the European Union', Journal of Common Market Studies, 43 (1).

Bardi, L. (2004) 'European political parties: a (timidly) rising actor in the EU political system', International Spectator, Istituto Affari Internazionali, pp. 17-30.

Bartolini, S. (2005a) Restructuring Europe, Centre Formation, System Building, and Political Structuring between the Nation State and the European Union (Oxford and New York: Oxford University Press).

Bartolini, S. (2005b) 'Political parties rise, consolidation, and decline (?) in Europe. A developmental perspective', paper, conference: 'New Challenges for Political Parties and Representation', University of Michigan, Ann Arbor, 6-7 May.

Bartolini S. (2006) 'Should the Union be 'politicised'? Prospects and risks', policy paper no. 19, www.notre-europe asso.fr.

Bellec, D. (2005) 'Europe sociale', in Y. Déloye (ed.), Dictionnaire des élections européennes (Paris: Economica).

Berman, S. (2006) The Primacy of Politics: Social Democracy and the Making of Europe's Twentieth Century (Cambridge: Cambridge University Press).

Callaghan, J. (2005) 'Social democracy and civil society', in P. Delwit (ed.), Social Democracy in Europe (Brussels: Ed. de L’Université Libre des Bruxelles). 
Callaghan, J. (2006) 'Old social democracy, new social movements and social democratic programmatic renewal, 1968-2000', in J. Callaghan and I. Favretto (eds), Transitions in Social Democracy (Manchester: Manchester University Press).

Caporaso, J. and Stone Sweet, A. (2001) 'Conclusion: institutional logics of European integration', in A. Stone Sweet, W. Sandholtz and N. Fligstein (eds), The Institutionalization of Europe (Oxford: Oxford University Press).

Cautrès, B. and Grunberg, G. (2007) 'Position sociale, identité nationale et attitudes à l'égard de l' Europe', in O. Costa and P. Magnette (eds), Une Europe des élites? (Brussels: IEE, Ed. de l'Université de Bruxelles).

Chryssochoou, D. (2005) For a European res publica (Athens: Papazissis [in Greek]).

Costa, O. (2004) 'Le parlementarisme au-delà del'Etat:lecas del'Union européenne', in O. Costa, E. Kerrouche and P. Magnette (eds), Vers un renouveau du parlementarisme en Europe? (Brussels: Editions de l'ULB).

Demertzis, V. (2005) 'Solidarity inside the EU: European solidarity without European welfare state', paper (University of Fribourg: ESPAnet Conference, 22-4 September).

Dunphy, R. (2004) Contesting Capitalism? Left Parties and European Integration (Manchester: Manchester University Press).

Egeberg, M. (2008) 'European government(s): executive politics in transition?', West European Politics, 31 (1-2).

Featherstone, K. (2004) 'The political dynamics of external empowerment: the emergence of EMU and the challenge to the European social model', in A. Martin and G. Ross (eds), Euros and Europeans (Cambridge, New York: Cambridge University Press).

Ferenczi, T. (2008) Pourquoi l'Europe? (Paris: André Versaille).

Fitoussi, J. P. (2005) La Politique de l'impuissance (Paris: Arléa).

Genieys, W. (2008) L'élite des politiques de l'Etat (Paris: Sciences Po, Les Presses).

Grunberg, G. and Moschonas, G. (2005) 'Le vote socialiste: les bénéfices du votesanction dans une élection de "second" ordre' in P. Perrineau (ed.), Le Vote européen 2004-2005, De l'élargissement au référendum français (Paris: Sciences Po, Les Presses).

Hanley, D. (2002) 'Christian democracy and the paradoxes of Europeanization', Party Politics, 8 (4).

Hansen, P. (2005) 'Still a European social model? From a vision of a "social Europe” to the EU reality of embedded neo-liberalism', Center for Ethnic and Urban Studies, 26, Linköping University, Sweden.

Hay, C. (2002) 'Globalisation, "EU-isation" and the space for social democratic alternatives: pessimism of the intellect: a reply to Coates', British Journal of Politics and International Relations, 4 (3).

Heidar, K. (2003) 'Parties and cleavages in the European political space', Arena Working Papers.

Hix, S. (2006) 'Why the EU needs (left-right) politics? Policy reform and accountability are impossible without it', policy paper no. 19, www.notre-europe. asso.fr.

Hooghe, L. and Marks, G. (2008) 'European Union?', West European Politics, 31 (1-2). 
Johansson, K. M. and Raunio, T. (2005) 'Regulating Europarties: Cross party coalitions capitalizing on incomplete contracts', Party Politics, 11 (5).

Kulahci, E. (2003) 'Le Parti des socialistes européens et le défi de légitimité socioéconomique de l'UE', Ph.D. Thesis (Brussels: ULB).

Ladrech, R. (2000) Social Democracy and the Challenge of European Union (London: Boulder).

Ladrech, R. (2003) 'The Left and the European Union', Parliamentary Affairs, 56.

Lavelle, A. (2008) The Death of Social Democracy: Political Consequences in the 21st Century (Hampshire and Burlington: Ashgate).

Lightfoot, S. (2005) Europeanizing Social Democracy? The Rise of the Party of European Socialists (London and New York: Routledge).

Lindvall, J. and Rothstein, R. (2006) 'Sweden: the fall of the strong state', Scandinavian Political Studies, 29 (1).

Lord, C. (2001) 'Les partis politiques au niveau européen: Quel type de concurrence imparfaite?, in P. Delwit, E. Külahci and C. de Walle (eds), Les fédérations européennes de partis: Organisation et influence (Brussels: Ed. de l'Université de Bruxelles).

McGowan, F. (2001) 'Social democracy and the European Union: Who's changing whom?', in L. Martell (ed.), Social Democracy, Global and National Perspectives (Hampshire and New York: Palgrave).

Magnette, P. (2001) 'Les contraintes institutionnelles au développement des partis politiques européens', in P. Delwit, E. Külahci and C. de Walle (eds), Les fédérations européennes de partis: Organisation et influence (Brussels: Ed. de l'Université de Bruxelles).

Magnette, P. (2005) What is the European Union? Nature and Prospects (Durham, NC: Palgrave Macmillan).

Mair, P. (2005) 'Popular democracy and the European Union polity', European Governance Papers, no. C-05-03.

Mair, P. (2008) 'The challenge to party government', West European Politics, 31 (1).

Majone, G. (1996) La Communauté Européenne: un Etat régulateur (Paris: Montchrestien).

Marks, G. (2004) 'Conclusion: European integration and political conflict', in G. Marks and M. Steenbergen (eds), European Integration and Political Conflict (Cambridge: Cambridge University Press).

Merkel, W. and Petring, A. (2007) 'Social democracy in power: explaining the capacity to reform', ZIVP, 1.

Moravcsik, A. (2001) 'Despotism in Brussels? Misreading the European Union', Foreign Affairs, May/June.

Moravcsik, A. and Sangiovanni, A. [n. d.] 'On democracy and "public interest" in the European Union', available at: http://www.princeton.edu/ amoravcs/ library/scharpf.pdf.

Moschonas, G. (2002) In the Name of Social Democracy: the Great Transformation (London and New York: Verso).

Moschonas, G. (2005) 'On the verge of a fresh start: the great ideological and 
programmatic change in contemporary social democracy', in P. Delwit (ed.), Social Democracy in Europe (Brussels: Ed. de L'Université Libre des Bruxelles).

Moschonas, G. (2007) 'Party of European Socialists', in Y. Deloye and M. Bruter (eds), Encyclopedia of European Elections (Durham, NC: Palgrave Macmillan).

Notermans, T. (ed.) (2001) Social Democracy and Monetary Union (New York and Oxford: Berghahn Books).

Pappas, T. (2006) 'Political charisma and liberal democracy', paper, conference: 'Penser la Démocratie. Autour de l'œuvre de Juan Linz', Montpellier, France, 7-9 September.

Perrineau, P. (2005) 'Le référendum français du 29 mai 2005', in P. Perrineau (ed.), Le Vote européen 2004-2005, De l'élargissement au référendum français (Paris: Sciences Po, Les Presses).

Luther Richard, K. and Muller-Rommel, F. (2002) 'Parties and party research in the New Europe', in K. Luther Richard and F. Muller-Rommel (eds), Political Parties in the New Europe (Oxford: Oxford University Press)

Ross, G. (2001) 'French social democracy and EMU: Presidential prose and its pitfalls', in T. Notermans (ed.), Social Democracy and Monetary Union (New York and Oxford: Berghahn Books).

Ross, G. (2009) 'Centre-lefts and the puzzles of European integration', in J. Cronin, G. Ross and J. Shoch (eds), Futures of the Left (Durham, NC: Duke University Press, forthcoming).

Ryner, M. (2007) 'US power and the crisis of social democracy in Europe's second project of integration', Capital and Class, 93.

Sassoon, D. (2006) 'Socialism in the twentieth century: a historical reflection', in J. Callaghan, and I. Favretto (eds), Transitions in Social Democracy (Manchester: Manchester University Press).

Scharpf, F. (1996) 'Negative and positive integration in the political economy of European States', in G. Marks, F. Scharpf, P. Schmitter and W. Streeck (eds), Governance in the European Union (London: Sage).

Show, M. (2001) 'Social democracy in the global revolution: an historical perspective', in L. Martell (ed.), Social Democracy, Global and National Perspectives (Hampshire and New York: Palgrave).

Smith, A. (2004) Le gouvernement de l'Union européenne - une sociologie politique, Maison des Sciences de l'Homme.

Stjerno, S. (2005) Solidarity in Europe: the History of an Idea (Cambridge: Cambridge University Press).

Telo, M. (2005) L'Etat et l'Europe (Brussels: Lavour).

Tsoukalis, L. (2005) What kind of Europe? (Oxford: Oxford University Press). 


\section{Part III}

\section{Resources for rethinking}





\title{
Unlocking the talent of every citizen: debates about potential and ambition in British socialist thought
}

\author{
Jeremy Nuttall
}

\begin{abstract}
Introduction
This chapter considers how British socialist and social democratic thought from the late nineteenth century to the present has treated the objective of helping people to fulfil their potential, talents and ambitions. Such an objective was, on the face of it, a central and relatively uncomplicated pillar of socialist thought: socialism claimed to stand for 'ordinary people' and an important part of this was seen to be about helping them to develop themselves in ways which they were constrained from doing by what was perceived to be an exploitative economic and social system. This meant increasing people's access to education, skills, the arts and leisure. It also meant seeking to broaden their moral and ethical horizons, partly as it was thought that this would make for more fulfilled and happier individuals, and partly because ethically minded and cooperative citizens were seen to be required for an ethical and cooperative (and by that was meant socialist) society.

Such an objective did indeed constitute a significant strand in socialist thought throughout the period discussed in this chapter, though in a wide variety of different forms. However, the chapter suggests the picture was also considerably complicated by several further influences and constraints. One was that there was often a wide gap between the socialist vision of a citizenry well provided for in terms of educational and cultural opportunities, and with a strong appetite for such opportunities, and the more prosaic reality. Another was that given the extent of the obvious and often dramatic material poverty people were enduring, especially in the earlier periods covered by this study, there was a general feeling, shared by some socialists themselves, that this tangible poverty of income, housing or health, or the flawed economic system that was claimed to have partly caused these problems, needed to be addressed before less tangible or more
\end{abstract}


'advanced' educational, cultural or 'psychological' improvements could be embarked upon. As socialists became increasingly familiar with the nature of people's lives and their (sometimes in socialist eyes limited) aspirations as they really were, they differed in their analyses and responses. Some, in the 1920s and 1930s, concluded that there might be genetic limits to people's ability to develop more 'advanced' levels of culture and intelligence. Others, more optimistic, in the 1950s and 1960s, saw an expansion of cultural opportunities and a move to comprehensive secondary education as ways in which people's opportunities could be enhanced and their horizons broadened.

Since the mid-1980s, socialists have focused ever more strongly on the issue of people's ambitions and talents as they have battled with the political right for the electorally rewarding association with concepts like social mobility, opportunity and 'getting on', and as individuals' expectations about what they can achieve, learn and enjoy have risen. Socialist assessments of the best means to liberate people's potential have also changed. Many now see education policy as being more important than nationalisation in enhancing people's life chances, and, more broadly, see the fulfilment of talent as depending on changes in attitudes, culture and behaviour as much as in economics, institutions and social structures. Yet disagreement remains among socialists as to how best to empower people to develop their potential. So does a sense that ultimately the socialist view of 'achievement' and 'ambition' is not the same as, and may at times be in opposition to, some contemporary definitions of those concepts in terms of becoming wealthy or famous, or achieving elevated status within a competitive framework.

Some existing historical research is relevant to the theme of this chapter. Rodney Barker has analysed the Labour Party's approach to educational issues in the first half of the twentieth century (Barker 1972). Steven Fielding, Peter Thompson and Nick Tiratsoo have explored Labour's perceptions in the 1940s of the limits to both people's political idealism and their enthusiasm for cultural 'enlightenment' (Fielding et al. 1995). Lawrence Black examined the impact of cultural and social changes during the 'age of affluence' in the 1950s and 1960s on socialist attitudes towards popular culture (Black 2003). David Marquand has written on the ways in which post-war socialist thought has fluctuated between seeing people as passive recipients of welfare on the one hand and active public-spirited citizens on the other (Marquand and Seldon 1996). Finally, my own research discussed how far the Labour Party's visions of socialism and equality since the 1930s entailed changes in the values and attitudes of society and citizens, and in their educational opportunities. It also considered how these ethical, psychological and educational dimensions interacted with 
other parts of Labour's agenda focused on economics, social structures and power (Nuttall 2006). All this work raises issues connected to that of people's potential. This chapter seeks to make a start on considering the subject of potential systematically in its own right.

It suggests that the topic is worth investigating for three reasons. First, it shows how the socialist agenda has to some degree shifted over the twentieth century from seeking to combat negatives, such as unemployment, poor housing and low incomes to encouraging positives, that is people fulfilling their ambitions and potential through, for example, education, careers they find rewarding or voluntary work in their communities. At the same time, though, combating 'negatives' has remained central to socialist thought. Second, a central aspect of political debate in modern British history has been disagreement about how much people's natures, achievements and unfulfilled hopes were due to, in turn, unalterable genetic character traits, effort (or the absence of it) or the influences of their various social environments, influences which could be improved through social change. This chapter seeks to cast light on the impact of these rival interpretations. This is important, not least because the very assumptions by socialists, and others, about what people could and could not achieve, may themselves have been a factor shaping people's chances of fulfilling their potential, whether in terms of the influence of those assumptions on policy, or their less tangible impact on people's expectations of themselves. Finally, the chapter concludes by arguing that Gordon Brown's party conference speech in 2007 represents something of a landmark in British political history in the extent to which it placed the idea of encouraging people's talents and ambitions at the centre of his political vision. It also points to some ways in which an emphasis on encouraging the development of people's potential, talents and ambitions has been, and can continue to be, of substantial benefit to socialists, in terms both of helping them to win elections and achieving some of their deepest objectives of equality and empowerment.

Two brief points about definitions should be made. I have defined socialist 'thought' broadly to include reflections by Labour politicians on how ideas ought to be modified due to practical experience. And I have used whichever of the labels 'socialist' or 'social democrat' tended to be used by the person or in the period I am discussing, thus usually 'socialist' for most of the period, and both terms in relation to the late 1990s onwards.

\section{The 1880s to 1931}

Late nineteenth- and early twentieth-century socialist thought generally retained a large measure of Enlightenment and Victorian optimism about the continuing progress of society through reason. There was also a belief 
that a socialist restructuring of the economy and the pursuit of the moral, educational and cultural 'uplift' of the citizenry would be mutually reinforcing. From this perspective, socialism existed both to combat material poverty and to provide new opportunities, time and encouragement for people to develop themselves educationally and psychologically beyond their formerly prescribed roles in the industrial production process. The Fabian Sidney Olivier, in his chapter on the moral basis of socialism in Fabian Essays (1889), contended:

The existence and stability of society are the indispensable guarantee for the general satisfaction of the primary desires of individuals ... but much more are [they] indispensable conditions for the common birth and satisfaction of the secondary desires, the desires which have created all that is most valuable in civilization and which find their satisfaction in art, in culture, in human intercourse, in love. (Shaw 1962: 145-6)

This meant that the 'schools of the adult' must include libraries, opera, drama and museums (Shaw 1962: 160). Ramsay MacDonald complained in 1905 that society had failed to 'enrich all its classes', not only with material possessions, but with 'character and capacity to employ leisure time' (MacDonald 1905: 8). Harold Laski's A Grammar of Politics (1925: 56, 88) called for people to be released from 'material and spiritual' servitude alike, and argued that the state existed to enable people to realise the best in themselves:

A State which builds, for example, an educational system which regards its citizens, not as helots, but as men, in which, as Plato desired, the Minister of Education is more important than the Minister of War, can at least mould conclusively an environment in which an appreciation of the best lies open to its members. (Laski 1925: 27-8)

Socialists, then, believed that under changed social conditions, people themselves would change. They would be stronger of character, more cooperative and more fulfilled in their leisure, cultural pursuits and work. It was judged that even if some people had limited horizons and aspirations under existing exploitative conditions this did not mean that this was their 'natural' and permanent psychological outlook. Rather, they had been constrained by the limits imposed on their opportunities and expectations. Higher aspirations and new skills could be learned through habit and training. Writing in Justice on 16 June 1894, William Morris emphasised that it must be remembered that civilization has reduced the workman to such a skinny and pitiful existence, that he scarcely knows how to frame a desire for any life much better than that which he now endures perforce' (Morton 1984: 245). In a lecture entitled 'The society of the future' seven years earlier, Morris revealed how wide a range of skills and attributes he believed 
people could develop if freed from society's existing division into propertyowners and property-servers, and from the division of labour itself:

All people should learn how to swim, and to ride, and to sail a boat on sea or river; such things are not arts, they are merely bodily exercises, and should become habitual in the race... Then again there are things like cooking and baking, sewing, and the like, which can be taught to every sensible person in a few hours, and which everybody ought to have at his fingers' ends. All these elementary arts would be once again habitual, as also I suppose would be the arts of reading and writing; as also I suspect would the art of thinking, at present not taught in any school or university that I know of. (Morton 1984: 197)

Some other socialists were at pains to emphasise that their desire to equalise educational, cultural and economic opportunities did not necessarily mean they believed all had equal capacities. R. H. Tawney, for example, influenced by psychologist Cyril Burt's research on the distribution of educational abilities, argued in 1931 that 'the fact that . . . individuals differ widely in their natural endowments, and in their capacity to develop them by education, is not open to question' (Tawney 1952: 36). What was important, nevertheless, was that 'whether their powers are great or small', everyone should 'be equally enabled to make the best of such powers as they possess' (Tawney 1952: 35-6). Education was a central part of Tawney's socialism, whether through his activities for the Workers' Educational Association or his writings, and he emphasised in 1924 his belief that it was 'an instrument of social improvement the potentialities of which are as vast as they are at present neglected' (Tawney 1924: 3).

Here was a vision of socialism, then, that saw equality as incorporating not only the reduction of material deprivation, but also the expansion of opportunities for intellectual and psychological growth. However, this broad aspiration for the fulfilment of citizens' intellectual and psychological potential was not always at the top of socialists' list of priorities. Nor was it always matched by a detailed appraisal of how it might be carried out. One reason for this was that the socialist focus on what they saw as the progress of society as a whole sometimes meant that it devoted less attention to what might be the aspirations and psychological make-up of individuals. This was perhaps especially evident in the Fabian tradition, where 'potential' was connected to a strong emphasis on social efficiency (sometimes ahead of an ethical, idealistic or psychological agenda). Thus, for example, Sidney Webb argued in 1889 that 'the perfect and fitting development of each individual is not necessarily the utmost and highest cultivation of his own personality, but the filling, in the best possible way, of his humble function in the great social machine' (Shaw 1962: 90).

A further reason for the limits to systematic socialist attention to the 
issue of the development of people's talents and potential in its own right was the tendency to see change in the structure of the economy as the prerequisite for improvement in people's intellectual and cultural opportunities. For Olivier, 'the most important influence in the repairing of social morality may perhaps be looked for not so much from the direct action of ... elements of the higher education [such as libraries, museums and the arts] as from those very socialist forms of property and industry which we believe to be the primary condition for allowing such higher education to affect the majority at all' (Shaw 1962: 160). Similarly, though Ramsay MacDonald saw the ultimate aims of socialism in moral and intellectual terms, for practical purposes he defined socialism as being about economic and industrial reconstruction. Psychological changes in the citizenry would follow from changes in the economic structure: as the communal organisation of industry 'becomes more efficient, the individual will respond with more intelligence and more character' (MacDonald 1905: 130, 185). Important too was the fact that in a late-nineteenth and early twentieth-century society of such evident poverty in terms of incomes, health, housing and urban environment the idea of tapping the depths of everyone's individual intellectual and other talents seemed a remote, and to some even an indulgent objective. Partly reflecting this, as Barker notes, the attention given to the issue of education by the Labour Party at a national level before the 1950s was sometimes rather spasmodic, though it was a more central concern at the local level $(1972: 12,97)$.

\section{From 1931 to 1979}

As the twentieth century developed, socialist understanding of the issue of people's potential changed in several ways, although a certain similarity in the overall pattern persisted through the century, and remains today - the philosophical commitment to releasing the full talents of people combined with an uncertainty about what this meant, or how to come even close to achieving it in a purportedly hostile social and political environment. One change was a growing sense of the disparity between theoretical socialist perspectives as to what people, given the fullest opportunities and encouragement, could become and what they actually were under existing social conditions. There were several different interpretations of this difficulty. Some were relatively gloomy. Under the influence of the post-First World War reaction, especially in academic psychology, against the apparent over-optimism of the Victorian faith in the onward march of reason, not least as evidenced by the mass slaughter of that war, the early socialist revisionist Evan Durbin reflected in the 1940s that intellectual education was 'not the panacea I used to be told that it was', and that 'about half 
the population - could never do more than pass into the Universities - or attain beyond the mental age of 16 only' (Durbin Papers: 4/7). Eugenics, more commonly associated with the far right, but seeming to some on the left to be a straightforward way of maximising the overall 'mental quality', as distinct from the racial purity, of the citizenry, were especially prevalent among Marxists and Fabians, and those socialists with scientific interests (Paul 1984: 567-8).

Other socialists were more hopeful, arguing that it was not surprising that people's intellectual and moral horizons were often limited, given their prescribed place at the bottom of a hierarchically organised society. Leonard Woolf, writing in 1931, emphasised the need to see people's evolution in a longer time scale than did those socialists expecting either democracy or revolution to bring an overnight improvement in citizens' mentalities:

It is difficult to find anything to bolster up the pessimism of those who do not like democracy. If the mass of the human race went forward one thousandth part of the distance that it has travelled since history began, when our forefathers were hardly as civilised or intelligent as are our dogs and cats today, the whole population would consist of Socrateses, Christs, Shakespeares, Newtons, and Beethovens ... From what we know of history there is not the slightest reason to believe that it is impossible for the man in the street to become in a few hundred years as cultured and intelligent and politically sagacious as any member of the present Cabinet ... Contemporary culture is the culture of masses just emerging from the barbarism to which they were condemned by aristocracy. (Woolf 1937: 213-15, 217)

Perhaps the dominant reaction of leading British socialist figures from the 1940s onwards, as socialism moved from being a movement of protest and aspiration to one of government and power, was to focus on some of the specific practical ways in which new services might be provided, and society, the economy and institutions be reorganised, so as to increase people's cultural and educational opportunities. Policy on culture and the arts was one such area. As Lawrence Black has illuminatingly shown, the 1950s and 1960s provided an interesting historical moment at which to view socialist ideas about culture, and about how they should interpret and react to the state of popular culture (Black 2003). A wide range of social and cultural developments were taking place in this period which are sometimes too readily conflated to support simple narratives of cultural decline or progress, including: increasing material affluence; greater access to education, information and travel; relaxation of laws relating to personal morality and artistic freedom; elements of cultural commercialisation and Americanisation; the provision of a greater choice of cultural and leisure activities; and a reaction against Victorian ideas about character and sexual restraint. In different ways these developments were perceived to 
generate both constraints and opportunities for socialists who themselves had differing visions of how the cultural and artistic potential of people could be unlocked. Some, for example, had concerns about what were perceived to be the cultural (and the consequent political) implications of a growing materialist consumerism. To Raphael Samuel, writing in a Fabian Tract in November 1959, 'Labour's primary task is to create a climate of socialist and radical opinion to oppose the ethos of the acquisitive society' (Fabian Society 1959: 35). The leading Labour left-wing figure at this time, Aneurin Bevan believed the working class had been seduced by consumerism. He even wondered if this was irreversible, telling Geoffrey Goodman during the 1959 election: 'History gave them [the working class] their chance [to embrace socialism] - and they didn't take it. Now it is probably too late' (Campbell 1987: 364).

Others, especially the liberal revisionist socialists, saw some more positive signs in contemporary cultural trends. Surveying the state of popular culture in 1962, Tony Crosland concluded:

There is surely no evidence of a decline in popular cultural taste ... The level of intellectual inquiry has manifestly risen. The notion of the nullifying, deadening influence of the media must seem strange to anyone accustomed to violent family or public-house arguments about newspaper articles or television programmes. And the theory of the passive, captive audience seems equally eccentric in the light of the intense and active family life in working-class areas with its immense range of hobbies, do-it-yourself activities, gardening, house-repair, and (the greatest change of all), family travel. (Crosland 1962: 201)

Even by the standards of what some saw as 'high culture', revisionists were encouraged by evidence of greater popular interest. Douglas Jay, for instance, reflected that attendance at 'serious' concerts by 1962 was far greater than before 1939 (Jay 1962: 350).

On the question of what, if anything, socialists should 'do' about culture, the revisionists tended to take a threefold approach. They were keen that those who had been denied the opportunity to enjoy such middle-class- or intellectual-associated pursuits as concerts or art galleries should have more opportunities to do so. At the same time they believed, on the grounds both of personal freedom and the need to avoid the appearance of preaching (not least because it could be electorally damaging for socialists), that the state and politicians should not be prescriptive about people's cultural and leisure pursuits. Finally, they also judged that the idea of ranking cultural activities was far too simplistic, partly because they themselves enjoyed activities from both the supposedly 'high' and the supposedly 'low' brow. Crosland, for instance, made much of his fondness for watching 'Match of the Day'. Gaitskell's comments in 1956 sum up the overall revisionist analysis: 
To me the pursuit of happiness has always seemed such an individual and personal matter that it is in the main best left to people themselves to decide, though evidently their capacity for making wise decisions in these matters is limited, if they have never been given the chance to appreciate a concert as well as a football match. What the State should do is to provide the framework, the opportunities through which people have the best chance of finding happiness through themselves. (Gaitskell 1956: 4)

Education was a second area where socialists could develop specific policies that might impact upon the development of people's potential. The movement to comprehensive secondary education and the expansion of higher and further education in the 1960s lay at the heart of this. The 1943 Norwood Report had argued that there should be different types of school for different types of mind, an argument implicitly accepted by the 1944 Butler Education Act. But the resultant division of secondary education into grammar schools for those taken to be more academic, and secondary moderns for the remainder, was challenged by psychological and sociological research in the 1950s, which suggested that there existed a too often untapped reservoir of ability among those not attending the grammar schools. This was drawn on by socialists, notably Tony Crosland. In his The Future of Socialism (1956), the leading statement of 'moderate' post-war British socialism, Crosland argued that both education and the expansion of cultural and leisure opportunities should become more central parts of the socialist and progressive agenda, as primary material poverty faded and as socialists realised that nationalisation was not the panacea some of them had once thought. Furthermore, as Secretary of State for Education between 1965 and 1967, Crosland was to implement a national policy of movement towards comprehensive secondary education. Referring to the academic research mentioned above, Crosland claimed in 1962:

We now know that measured intelligence is not a purely innate characteristic; it is at least partly an acquired one. With this knowledge, the whole discussion of 'equal opportunity' takes on a new aspect . . . Intelligence is acquired by teaching, stimulation and encouragement; and the amount of these available to the child will vary with social background ... The 'strong' definition [of equality of opportunity, which Crosland favoured] is therefore that, granted the differences in heredity and infantile experience, every child should have the same opportunity for acquiring measured intelligence, so far as this can be controlled by social action. (Crosland 1962: 172-3)

Parents' expectations for their children's education rose in the 1950 s and 1960s in line with the general increase in social mobility, as well as the beginnings of a realisation that employment in traditional manufacturing jobs could no longer be so heavily relied upon as an alternative to gaining other skills and qualifications. Crosland's predecessor as Education 
Secretary, Michael Stewart, reflected that whereas 'in the 1940s parents would ask that their child be allowed to leave school before the statutory age in order to take a job', 'by 1970 such requests were unknown' (1980: 257). Both citizens' and socialists' expectations of the potential of educational reform had, by the 1970s, risen to the extent that Shirley Williams, Education Secretary during Jim Callaghan's premiership, could visualise the role for comprehensives as being 'to transform the country from one in which few children went on to higher education to one in which most children would seek university or technical qualifications as their natural goal' (Williams 1996).

However, research and policy experience were also now beginning to point to a more multilayered understanding of the complex psychological constraints on educational progress. Crosland noted in 1962:

A child's vocabulary, its interest in its surroundings, its very ability to perceive, are conditioned by its early family life; the less educated the parents, the less these will be stimulated ... Parents who themselves left school early are more likely to persuade their children to leave school early. The fact of early leaving, since IQ is partly a function of the amount of education, still further increases the gap between children from different backgrounds; in other words, the child from the less fortunate background is penalized at a series of successive stages - and its own children will be penalized in the next generation ... [This points to the need for] a major educational revolution, so that parents, having been properly educated themselves, will stimulate the faculties of their children. (Crosland 1962: 172-3)

In contrast to both high socialist hopes for an immediate transformative impact from educational expansion, and Conservative criticisms of the perceived failure of comprehensives rapidly to deliver this promised educational improvement, the implication of Crosland's analysis was that the process of developing people's educational potential could be a long one, given the challenging task of breaking through the cycle of low educational expectations transmitted through parents from one generation to the next. The sociologist A. H. Halsey, who had also been Crosland's educational adviser, even suggested in his 1977 Reith Lectures that the relationship between parent and child had been 'of greater moment in changing the character of the learning process among children than all the expansion and reorganization of schools which has gone on since the Education Act of 1944' (Halsey 1978: 109). Others did not go this far, but Crosland himself conceded in an interview with George Gale in April 1974 that research now indicated that 'we were inclined, 20 years ago, to exaggerate the effect of education, taken alone, on people's life chances' (Crosland Papers: 13/20, 327).

There was a growing feeling that the move to comprehensives had not 
fully met the expectations of dramatic educational progress that some of their supporters had expected. Critics also highlighted the poor discipline in some schools and claimed that mixed ability teaching provided insufficient stimulus for pupils to improve. Consequently, the argument was increasingly voiced from the 1970s that the brand of educational egalitarianism practised by Labour governments was not advancing, or was even constraining, those people who aspired to improve and push themselves. This was accompanied by the broader contention that high taxation and state provision were 'crowding out' entrepreneurial talent and reducing incentives to develop oneself. One of the leading intellectual exponents of New Right thinking in the 1970s, Keith Joseph, insisted in his book Equality (1979) that egalitarianism appeared to legitimise resentment of talent (1979: 56, 125). Yet such criticism was not confined to the right. It was also beginning to be made from within socialist circles, especially revisionist ones. One young revisionist, John Mackintosh, suggested, in a 1978 article dramatically entitled 'Has social democracy failed in Britain?', that those taking the Croslandite egalitarian position would now have to pose themselves questions such as:

Does equality mean that within one comprehensive school there should be no streaming according to ability or even no examinations? If so, does there come a point where the lack of any indicators of ability or effort militates against the working class child with no connections? (Mackintosh 1978: 269)

Socialists were no longer as confident as they had been in the seemingly simpler times fifty years earlier that they knew straightforwardly how to liberate the potential of ordinary people. And the then apparently indisputable claim that socialism or labour movements stood for the ambitions and upward mobility of 'ordinary people' was now increasingly strongly contested by the right.

There was also a related argument about whether post-war socialism had demanded a sufficiently active role for citizens. Focused as it was on extending and dispensing welfare provision for people, it had, some friendly critics now claimed, spent too little time reflecting on what might be expected from them. This criticism was most starkly articulated by the Jenkinsite revisionist David Marquand in his 'Inquest on a movement', published in Encounter in July 1979. He argued that what he saw as post-war statist Fabian social democracy had drawn too little from the New Liberal tradition's emphasis on moral persuasion and individual autonomy. Social democrats 'seemed more anxious to do good to others than to help others to do good to themselves' (1979: 9-11). In the sphere of mainstream practical Labour politics, Jim Callaghan reflected that he had learned by the 1970 s that 'it is not enough to enforce changes in the economic structure 
to ensure the fulfilment of ideals. These require changes also in human attitudes and relationships' (1987: 396).

As historians, we should be wary of analyses that carry this too far and use the stick of hindsight to beat the socialism that stretches from the 1940s to the 1970s. In those decades, the state did seem to most socialists, and many progressives who were not socialists, to be an important instrument for empowering people by providing them with a wide range of securities and opportunities not available to them before. There would be few even on the political right who would dispute that some of the extensions of state activity in the spheres of health, education, housing and social security had a significant enabling impact upon people's lives. Equally, though, there was to be increasing agreement among socialists from the mid-1980s onwards that socialism must make a renewed effort to show that it was on the side of aspiration, mobility and talent, and not only social justice and compassion. There was a feeling also that what was a rather masculine and white labourist and socialist culture should devote more attention to the potential of women and ethnic minorities. Furthermore, this revised socialist vision for releasing people's potential increasingly explored issues such as participation, attitudes, behaviour, culture and what was actually occurring in public services on a detailed micro-level, and did not only concentrate on large-scale economic, social structural and institutional changes.

\section{From 1979 to the present}

The political pressure of repeated electoral defeats after 1979 allied with socialist intellectual reflection to produce this stronger emphasis on aspiration. Labour lost significant numbers of skilled and 'upwardly mobile' working-class voters to a Conservative Party under Margaret Thatcher which emphasised its offer of wider home- and share-ownership and a new culture of entrepreneurship. Bryan Gould recalls his belief in 1983 that the Conservatives rather than Labour were seen as 'the liberator of workingclass ambitions', and that 'Labour could not hope to be re-elected if we allowed ourselves to be seen as a party which stopped people from doing things, which prevented them from realising their aspirations' (Gould 1995: 152). Labour's problem had been, Tony Blair asserted in his party conference speech of 28 September 1999, that "people were made to feel we wanted to hold them back, limit their aspirations, when in truth the very opposite was our goal' (Conference 1999). In fact, he contended in his speech of 2004, 'the reason for our struggle against injustice has always been to liberate the individual' (Conference 2004). Similarly, to Gordon Brown, in a 1999 article entitled 'Equality - then and now', 'the issue for 
socialists is not so much about what the state can do for you but about what the state can enable you to do for yourself' (Leonard 1999: 44).

Aside from abandoning their opposition to several policies mainly associated with or originating from the Conservatives, such as council house sales, restrictions on trade union power, privatisation and lower income tax levels, social democrats also sought to re-emphasise, sometimes in different forms than in the past, the ways in which traditional social democratic approaches could be supportive of people's aspirations to advance and improve themselves. Education was again central here. This was partly because the growing appetite for higher education could be seen as strongly egalitarian. It was also because Labour could present its emphasis on the importance of 'human capital' and the continuous raising of skill levels as evidence both of a forward-looking economic approach in the context of the decline in traditional manufacturing jobs and increased global competition, and of a commitment to provide training for people to empower them individually. As Brown put it in his first party conference speech as Labour leader on 25 September 2007: 'Up against the competition of two billion people in China and India, we need to unlock all the talent we have' (Conference 2007). In line with its claim to reconcile objectives that in previous decades had been unnecessarily presented as opposites in the leftright struggle, New Labour's 1997 Education White Paper claimed that in the past the pursuit of excellence in education was 'too often equated with elitism', and proposed to combine the promotion of greater educational opportunity for those previously denied it with furthering high educational standards, that is to say 'excellence for everyone' (Department for Education 1997: 145, 147).

There was also now an increasing emphasis on the importance of the quality of children's experiences in their early years and of their upbringings as determinants of how far they would be able to fulfil their potential as adults. Blair's view was that 'the life-chances of children are hugely influenced by their earliest experiences' (Blair 2002), and also that 'parents are a child's first and most important teacher' (Blair 1996). Two of Labour's six pre-election pledges in February 2005 focused on children. The first, with a vision of 'your child achieving more', dealt with education, and the second, 'your children with the best start', offered more choice over parental leave, and greater provision of childcare and after-school care (Pledges 2005). This was perhaps partly an electoral device, appealing to society's insistence on a rhetoric of children coming first. But it also reflected a real shift across the political spectrum, which had been developing for several decades, towards a greater attention to areas relating to children's early years, not least as a reflection of the increased political influence of feminist ideas. 
In part this emphasis on early years and upbringing was directed at the improvement of individual life chances. Equally, it chimed with the traditional social democratic aim of enabling people to fulfil their social and moral potential as cooperative, public-spirited and perhaps even egalitarian-minded citizens. In a pamphlet published in 1995 entitled Family and Community Socialism, the ethical socialists Michael Young and A. H. Halsey, who had long highlighted what they saw as the importance of community and fraternity to socialism, suggested that they themselves and other socialists had been mistaken in the elevated status they had in the past accorded to nationalisation. The assumption that public ownership would make people behave better towards each other had, they claimed, been proved to be a mistake. The task now was to define socialism more directly in terms of relationships and community (Young and Halsey 1995: 1, 30). They stressed their belief that children were dependent upon their parents' care. A serene and stimulating childhood had direct ideological and political implications because it would foster the 'ability to transcend self-interest and regard the interests of others as in some way their own which is the sinew of any society' (Young and Halsey 1995: 11).

The increasing focus on micro-policy and on subjects such as education and children, and not just on macro-policy, economics and institutional change reflected a broad and growing sense among many social democrats that generating real opportunities for people required changes in culture, attitude and behaviour as much as in structures, laws or income levels. In a speech at Ruskin College, Oxford in December 1996 Blair called for the development of 'an ethic of education', reflecting his belief that 'culture, attitude and expectations are critical to successful education' (Blair 1996). Similarly, the government's 1997 Education White Paper insisted that 'effective change in a field as dependent on human interaction as education requires millions of people to change their behaviour' (Department for Education 1997: 146). Writing in 1998, leading New Labour thinker Anthony Giddens suggested that welfare had become more a 'psychic' than an economic concept. Consequently, he argued, counselling might now be more useful to people than direct economic assistance (Giddens 1998: 117). Social democrats now increasingly focused not only on what they saw as a deprivation or poverty of material conditions but also, as Peter Mandelson put it in 2001, on a 'poverty of individual expectations', or a 'poverty of hope' resulting from demoralised communities (Mandelson 2001).

There were two, in some respects contrasting, ways in which New Labour placed an increased emphasis on attitudes and behaviour. One stressed 'responsibility' and good behaviour as a personal moral choice, something individuals could achieve if they wanted to. Along these lines, Blair argued that it was essential for Labour to break free from the view 
that social considerations weakened personal responsibility for crime and disorder' (Blair 1998: 12-14). A second approach was similar to the first in its rejection of an economic determinism which explained crime, behaviour or levels of achievement in terms of material poverty alone, but rather than replacing this with a belief that individuals had complete freedom of will or control it posited a pluralist view of causation in which economic, cultural, psychological and other causes intermingled. Proponents of the first view pointed to examples of how people had managed to overcome great disadvantage through force of will. Advocates of the second perspective suggested that such willpower was itself a resource more readily available to some people than others. David Blunkett, when asked in March 2004 whether his achievement in overcoming obstacles posed by his blindness, or his father's death in a workplace accident when he was 12, to become home secretary made him less sympathetic to those who failed to overcome their own obstacles, offered a response that is revealing about the ways in which he has had a foot in both of the above camps:

I plead guilty, certainly in my earlier days, to not fully understanding how some inadequacies - some difficulties in life - make it more of an obstacle than it was for me, for some people to go out and fight for what they wanted. I was tempted to say, 'Look here, it's in your own hands. Do something about it.' When I went into schools [Blunkett had previously been Education Secretary], I used to say, 'If I can do it, you can have a crack at it.' I do have to restrain that element in me. (Blunkett March 2004)

In practice both approaches co-existed in New Labour and often in individual social democrats, and there were obviously many different gradations of position along the spectrum from a belief in complete free will to complete determinism. The positions were not necessarily wholly contradictory, as a pluralist view of causation could incorporate a belief in some freedom of individual choice. But it is worth noting that the above two broad positions often had different origins and produced different proposed remedies. The first position had roots in traditional and religious views of morality, as well as in 'tough-minded' labourist and working-class culture, was driven partly by the electoral appeal of the simplicity of its view of causation, and stressed punishment. The second had its origins in liberal social democracy and in sociological and other academic research, and emphasised understanding, encouragement and policy responses appropriate to a belief that the constraints on potential were complex and multilayered.

Since the 1990s, the belief in a need for an increased focus on attitudes and behaviour in explaining constraints on, and furthering the development of, people's potential has been generally shared across the social democratic spectrum. But there has also been strong criticism from some 
social democrats that New Labour has, in the process of upgrading the importance of attitudes, excessively downgraded the role of structures and power as determinants of people's life chances. Bill Rodgers, one of the SDP's 'Gang of Four', and now a Liberal Democrat, has complained that under New Labour 'there is a tendency to treat the poor not as victims but as perpetrators' (Rodgers 2000: 293). The most vocally expressed criticism of New Labour's education policies from within the Labour Party has come from its Croslandite ex-deputy leader Roy Hattersley. Hattersley has remained committed to the traditional egalitarian emphasis on promoting equality through income redistribution and egalitarian structures, especially comprehensive secondary schools. He has represented those socialists strongly opposed to New Labour's introduction of an element of selection in schools' admissions policies, asserting in January 2003 that:

the conduct [of the government] which had alienated so many natural Labour supporters was exemplified by one phrase - 'standards not structures' ... The two ingredients of schools policy are indivisible. To pretend that they can be separated raises fundamental questions about the government's honesty. (Hattersley 2003)

On the 'soft left', Frank Dobson has argued that socialism requires 'a considerable equity of wealth and an equity of power which we don't have' (Dobson 2003). None of these strands of criticism have recommended either an abandonment of New Labour's attention to attitudes and behaviour or a complete return to the approaches of the pre-mid-1980s period. But they indicate the existence of a range of different social democratic analyses of the relative importance of attitudes, structures and power (and the nature of the relationship between these three) in affecting people's opportunities.

What does seem certain is that changes in Labour's language, ideas and policies since the mid-1980s have enjoyed substantial success in convincing people that the party has become more focused than before on the specific ways in which their ambitions and talents could be fulfilled. New Labour's three successive election victories were due in important part to this change in perception. Equally, though, there remain issues and debates about what exactly 'ambition' and the fulfilment of potential might mean, and how far the social democratic view of it might be different from that of the free-market right, and perhaps even from that of many citizens. In an article entitled 'Ambition and New Labour' in May 2001, Peter Mandelson argued that the concept of 'ambition' should be New Labour's compass during its second term and beyond it. But he emphasised that his definition of ambition was not simply about earning more money:

What exactly do social democrats mean by promoting ambition? First, it is clearly more than satisfying the instinct to get on in the market economy, 
though business enterprise is an important means of realising ambition. New Labour needs to promote the idea that personal success is not judged only in terms of financial worth. Being ambitious is about individuals enhancing their sense of self-respect and well-being, maybe in 'conventional' forms of work, but also by volunteering, caring and following creative or intellectual pursuits. What concerns social democrats is that the means of realising personal ambition are shared equally. Equally important is being ambitious for our society, not just removing harsh and intolerable social injustices, but promoting a culture where people genuinely have equal worth. (Mandelson 2001)

Mandelson is often viewed by social democratic critics as the quintessential representative of a New Labour approach that has accommodated itself too far to a market agenda which values competition and the profit motive to the exclusion of all else, so this is an interesting complication of that picture, though, of course, it does not necessarily disprove the critique. More crucially for this chapter, it also illustrates the extent to which social democratic visions of what it means to develop one's potential and talent see much still to be done, and ultimately demand quite fundamental changes in what society values.

In education, for instance, some social democrats, while applauding the extensions of access to further study to vast numbers who would previously have left school at 16 , are less at ease with contemporary utilitarian interpretations of the function of education which see it only as a pathway to higher earnings and status. Giddens's judgement was that 'although training in specific skills may be necessary for many job transitions, more important is the development of cognitive and emotional competence' (Giddens 1998: 125). Michael Barber, academic educationalist and head of the Blair government's Delivery Unit expressed his desire for a 'thoughtful society', and stressed that 'it ought surely to be a central purpose of schools that young people learn the ability to reason', noting that it would be ironic if the increasing public access to information coincided with a loss of the capacity to think about that information intelligently (Barber 1996: 17, $179,181)$.

\section{Conclusions: the future}

The argument that everyone should have the chance to make the best of their abilities has long been an important part of what Labour, and to some extent also the Conservative Party, have promised at the level of broad aspiration and in certain practical social policy areas. But they have not tended to discuss or analyse the issue at length. The aim has often been allocated one or two lines in a general election manifesto, but left undeveloped. This 
is perhaps unsurprising given, as noted earlier, the seemingly abstract, intangible nature of the idea of 'potential' among the many everyday practical policy challenges as well as the very wide range of constraints on the achievement of potential, some of which government has had only marginal ability to counteract.

However, there are some hints that this may be beginning to change. They were already evident in the Blair Government's greater emphasis on education, childhood, attitudes and behaviour. But it was in new Prime Minister Gordon Brown's party conference speech of 2007 that the idea of encouraging talent, potential and ambition was given central, extended and intellectually fairly systematic treatment, possibly more so than in any previous well-publicised British Prime Minister's speech. By way of illustrating its centrality in the speech, it is worth listing several phrases: Brown referred to teenage friends whose "potential had never been nurtured'; 'when they heard about further education, they thought, or their parents thought, it was not for people like them'; he believed that 'everyone should rise as far as their talents can take them'; 'whenever we see talent under-developed; aspirations unfulfilled; potential wasted; obstacles to be removed; this is where we - New Labour will be'; he wanted a situation in which 'everyone has the chance to make the most of themselves'; he was convinced that the most important challenge ahead was to meet 'the rising aspirations of the British people'; 'in Britain today too many still cannot rise as far as their talents can take them'; 'this is the century where our country cannot afford to waste the talents of anyone'; 'the country that brings out the best in all its people will be the great success story of the global age'; 'how much talent that could flourish is lost through a poverty of aspiration: wasted not because young talents fail to reach the stars but because they grow up with no stars to reach for?'; he wanted a Britain 'where all are encouraged to aim high' and one 'not divided by class but united by aspiration' (Conference 2007).

One should not, of course, exaggerate the significance of one speech. Moreover, part of the motive for using the language of talent and potential was rhetorical, designed to maintain Labour's association with aspiration and upward mobility. And there remain considerable tensions between visions of ambition and social mobility built exclusively around the competitive acquisition of material and status rewards and those broader conceptions of ambition that animated thinkers such as Morris and Tawney. They sought to develop citizens' moral, intellectual and cultural, and not just economic, potential and they also considered the potential of society as a whole, not only that of atomised individuals.

Nevertheless, the speech does seem symbolically important, partly for what it highlights about the growing centrality in social democracy, and in 
British politics and society more broadly, of issues of talent and potential, and partly because it illuminates some of the benefits (past, present and future) to social democracy of an emphasis on developing people's talents, potential and ambitions. First, such an emphasis has been and is optimistic, positive and constructive, rising above the class conflict agenda of some on both the left and the right. Second, there is also a strong egalitarian emphasis on inclusion - it is about liberating the potential of everybody. Third, the social democratic analysis of the development of potential is now often relatively multilayered, since it acknowledges the complexity of the different obstacles to people developing their full potential, seeks to change both structures and attitudes rather than only one or the other, and focuses on ways of overcoming the 'poverty of aspiration' in which structural and attitudinal barriers conspire and intermingle together. Finally, voters have associated words such as talent and potential with other words which they often find attractive such as optimism, mobility, inclusion, ambition and opportunity, and these associations mean that 'talent' and 'potential' have been and are likely to continue to be concepts from which Labour can benefit electorally. Promising to help people fulfil their talents and potential, then, can both help social democrats to stay in office and help them to advance some of their most central egalitarian and social democratic objectives. At the same time, there remain crucial differences between popular definitions of ambition in terms only of material and status rewards and more idealistic social democratic definitions. Given all of these points, there may be considerable benefits in a twofold strategy. This would employ the language of talent, potential and ambition broadly and attractively before voters, but simultaneously seek to re-shape and develop people's visions of what those terms might mean.

\section{References}

Books, pamphlets and articles

Barber, M. (1996) The Learning Game: Arguments for an Education Revolution (London: Victor Gollancz).

Barker, R. (1972) Education and Politics 1900-1951: a Study of the Labour Party (Oxford: Clarendon Press).

Black, L. (2003) The Political Culture of the Left in Affluent Britain, 1951-64: Old Labour, New Britain? (Basingstoke: Macmillan).

Blair, T. (September 1998) The Third Way: New Politics for the New Century, Fabian Pamphlet 588.

Blair, T. (10 November 2002) 'My vision for Britain', Observer.

Callaghan, J. (1987) Time and Chance (London: Collins).

Campbell, J. (1987) Nye Bevan and the Mirage of British Socialism (London: Weidenfeld \& Nicolson).

Crosland, C. A. R. (1962) The Conservative Enemy (London: Cape). 
Department for Education and Employment (1997) Excellence in Schools, White Paper (London: The Stationery Office).

Fabian Society (November 1959) Where: 5 Views on Labour's Future, Fabian Tract 320.

Fielding, S., Thompson, P. and Tiratsoo, N. (1995) 'England Arise!': the Labour Party and Popular Politics in 1940s Britain (Manchester: Manchester University Press).

Gaitskell, H. (July 1956) Socialism and Nationalisation, Fabian Tract 300.

Giddens, A. (1998) The Third Way: the Renewal of Social Democracy (Cambridge: Polity Press).

Gould, B. (1995) Goodbye to All That (London: Macmillan).

Halsey, A. H. (1978) Change in British Society (Oxford: Oxford University Press).

Hattersley, R. (27 January 2003) 'Rule one: never talk about Kent', Guardian.

Jay, D. (1962) Socialism in the New Society (London: Longmans).

Joseph, K. and Sumption, J. (1979) Equality (London: John Murray).

Laski, H. J. (1925) A Grammar of Politics (London: Allen \& Unwin).

Leonard, D. (ed.) (1999) Crosland and New Labour (Basingstoke: Macmillan).

MacDonald, J. R. (1905) Socialism and Society (London: Independent Labour Party).

Mackintosh, J. (1978) ‘Has social democracy failed in Britain?’, Political Quarterly, 49.

Mandelson, P. (6 May 2001) 'Ambition and New Labour', Observer.

Marquand, D. (July 1979) 'Inquest on a movement: Labour's defeat and its consequences', Encounter, 53.

Marquand, D. and Seldon, A. (eds) (1996) The Ideas that Shaped Post-war Britain (London: Fontana).

Morton, A. L. (ed.) (1984) Political Writings of William Morris (London: Lawrence \& Wishart).

Nuttall, J. (2006) Psychological Socialism: the Labour Party and Qualities of Mind and Character (Manchester: Manchester University Press).

Paul, D. (1984) 'Eugenics and the left', Journal of the History of Ideas, 45.

Rodgers, B. (2000) Fourth Among Equals (London: Politico's).

Shaw, G. B. (ed.) (1962) Fabian Essays (London: Allen \& Unwin).

Stewart, M. (1980) Life and Labour: an Autobiography (London: Sidgwick \& Jackson).

Tawney, R. H. (1924) Education: the Socialist Policy (London: Independent Labour Party).

Tawney, R. H. (1952) Equality, 4th edn. (London: Allen \& Unwin).

Woolf, L. (1937) After the Deluge: a Study in Communal Psychology (Harmondsworth: Hogarth Press).

Young, M. and Halsey, A. H. (1995) Family and Community Socialism (London: Institute for Public Policy Research).

Unpublished private papers, interviews and other sources

Tony Blair's speech at Ruskin College, Oxford, 16 December 1996.

David Blunkett interviewed by Roy Hattersley, Observer, 7 March 2004. 
Tony Crosland Papers, British Library of Political and Economic Science, London. Evan Durbin Papers, British Library of Political and Economic Science, London. Interview with the author: Frank Dobson, 14 October 2003.

Labour Party Annual Conference Reports.

Labour's Six Pledges, February 2005.

Williams, S. (1996) Snakes and Ladders: a Political Diary. BBC Radio Collection. 


\title{
The continuing relevance of Croslandite social democracy
}

\author{
Kevin Hickson
}

The aim of this chapter is to argue that as social democrats look for an alternative to the New Labour/Third Way approach, as they inevitably must do given the rather moderate nature of many areas of domestic policy since 1997 and given the current economic crisis (leaving aside the disastrous foreign policy adventures of the Blair years, notably of course Iraq), we could find a number of relevant ideas in the British social democratic tradition, specifically in the work of Tony Crosland (1918-77). This is not to argue that Crosland's work is directly or entirely relevant to the contemporary situation. Over fifty years have passed since he wrote his major work, The Future of Socialism (Crosland [1956] 1963) and over thirty since his last significant publication, Socialism Now (Crosland 1974). Indeed, the essence of his argument was the need to revise the meaning of socialism as circumstances changed. The period since Crosland's death has marked a period of significant challenge to the socialist position he outlined, both intellectually in the form of the New Right and in terms of economic and social changes both domestically and internationally. Any attempt to restate a Croslandite socialist position would need to take account of such changes. Moreover, this chapter is not an attempt to state what Crosland would think if he were alive today. Such a statement would be impossible, although some, for example Gordon Brown, have tried to make it (Brown 2006). There is simply no way of knowing what Crosland would make of the twelve years of New Labour government since 1997. However, this does not mean that we cannot relate the ideas contained in The Future of Socialism to the contemporary situation, as Mark Wickham-Jones has argued in a recent article. While this chapter cannot consider all of Wickham-Jones's arguments, we can at least say that Crosland's ideas contain a theoretical core, based around a clear conception of equality, which, contrary to Wickham-Jones, can be applied to contemporary politics (Wickham-Jones 2007). Instead, all that can be done is to outline Crosland's position and how he responded 
to his critics and then to suggest in what ways his ideas can be reapplied to the contemporary situation.

The chapter begins by outlining the main arguments contained in The Future of Socialism. These consist of first an account of the transformation of the British economy, which was followed by a discussion of socialist aims and finally an analysis of the policies most appropriate for their attainment. Of fundamental importance for the revisionist position was the distinction between values and policies, or ends and means as they were labelled. The chapter then goes on to discuss the criticisms made of Crosland's arguments. Of these, the intellectual challenge from the New Right was the most serious and we need to discuss how revisionists in the 1980s sought to defend social democracy in the face of this intellectual challenge. The chapter also discusses certain wider empirical developments, which some commentators have argued spell the death of social democracy. Finally, the chapter seeks to demonstrate the continuing relevance of core elements of Croslandite social democracy. Briefly, these are the primary emphasis on equality as a guide to social democratic policies and the need to take the issue of corporate ownership seriously once again in the face of economic developments which have moved rather contrary to the trends that Crosland identified in the 1950s. There is therefore a lot of ground to cover when we examine the continuing relevance of Croslandite social democracy and inevitably this will involve touching on some of these issues rather briefly. ${ }^{1}$

\section{Crosland's thesis}

The Future of Socialism constitutes the major statement of post-war social democracy in Britain. There were other theoretical contributions to British social democracy after 1951, most notably by Roy Jenkins and Douglas Jay, but none provided the synthesis that Crosland's text provided (Jenkins 1953; Jay 1962). The first section of The Future of Socialism concerned the transformation of the economy (Crosland 1963: 1-42). Here Crosland talked of a transfer of power away from the capitalist class. When Marx had outlined his arguments for socialism the economy was structured around small-scale ownership, primarily the new mills and factories of the industrial revolution. The owners constituted a powerful social class in the absence of a welfare state and with only limited government intervention in the economy and the lack of strong trade union movements. For Marx, the owners of the means of production determined the distribution of wealth and income. On this view, issues of distribution cannot be separated from the structure of production and so the only possibility of creating a fairer society is to foster conditions for a revolution in which private property ownership would be terminated. ${ }^{2}$ 
However, by the end of the nineteenth century, social democrats were beginning to revise these fundamental tenets of Marxism, notably with the publication of Eduard Bernstein's The Preconditions of Socialism (Bernstein [1899] 1993). This revisionist tradition was important to Crosland's intellectual development and he sought to provide a similar tract for British social democracy in post-war conditions. He drew on the ideas developed in the academic literature about the separation of ownership and control within industry and the so-called 'managerial revolution', in which a managerial elite had emerged divorced from the old capitalist class (Berle and Means 1932; Burnham 1942). Specifically, Crosland identified four recent trends within political economy. The first was the transfer of power away from owners to the state. This was partly due to the nationalisation programme of the post-war Labour Government, which nationalised mostly loss-making industries amounting to one-fifth of the economy. However, the decisive factor in the transfer of power away from owners to the state was the development of Keynesian economic techniques, which provided the state, so Crosland believed, with sufficient power to regulate the private sector of the economy and maintain full employment and the growth that was needed for the expansion of social services. The second transfer of power away from owners was to labour, especially in the form of the trade unions, which derived their powers partly from the new, postwar structure of industrial relations but largely from the condition of full employment. Third, Crosland believed that there had been a transfer of power from owners to managers. This was important for a number of reasons. Crosland believed that the dispersal of ownership to a larger shareholding class, something which was necessitated by the increase in the size of the corporate unit, had divorced ownership from control in industry and that control now rested with managers rather than the traditional capitalist class. Hence, those in control of industry were no longer constrained by the overarching need to maximise profit, but rather could consider a wider range of corporate responsibilities. Finally, Crosland stressed the ability of democratic processes to transform the nature of the economy and society. By forming democratic political parties, trade unions, and so forth the workers and their representatives had been able to reduce poverty and enlarge the state so that it could counteract the effects of capitalism, for example with the formation of the welfare state and the achievement of full employment. Hence, social democracy had disproved the Marxist thesis that socialist advance could not be realised within liberal democracies. Crosland went so far as to argue that such conditions were not only the temporary reality but would be more enduring phenomena, not least as the Conservative Party had been forced to adapt to the new conditions for electoral survival. In fact, Crosland argued that the economy was no longer 
capitalist in any way in which commentators from the nineteenth century would recognise (Crosland 1963: 42).

Having set out the changed conditions, Crosland then sought to redefine the meaning of socialism (Crosland 1963: 43-80). Crosland argued that there was not a single 'true' form of socialism. Instead it was possible to identify a range of distinctive positions from the history of socialism. There were twelve socialist doctrines identified by Crosland: the natural law tradition, Owenism, the labour theory of value, Christian socialism, Marxism, the theory of rent as unearned income, anti-commercialism, Fabianism, the Independent Labour Party tradition, welfare state/paternalism, syndicalism and guild socialism and finally the doctrine of planning. The significance of this categorisation of socialism was to highlight the core values of that doctrine. Here Crosland specified five such aspirations: a protest against material poverty; the promotion of social welfare; the pursuit of equality and the creation of a classless society; the formation of social solidarity and community and finally a protest against the inefficiencies of capitalism and in particular the creation of full employment. Of these five aspirations Crosland argued that the first and last were no longer relevant as primary poverty had been alleviated apart from a residual poverty in some sections of society and the transfer of power discussed above had created a more efficient economic system; full employment was by the 1950s well established and accepted as the principal aim of economic policy by both of the major parties. The fourth aim of promoting cooperation and a stronger sense of community Crosland said that he fully supported but not at the expense of personal liberty and indeed felt that this would not be a particularly significant objective for socialists at that stage since there was in any case a stronger sense of community than had existed in pre-war conditions. The major socialist objectives should therefore be welfare and equality. Of these the promotion of welfare was needed to eliminate the remaining cases of primary poverty and above all to improve public services. Crosland placed even greater emphasis on equality and here the discussion becomes more conceptual.

Discussion of equality as a political concept usually involves making a distinction between equality of opportunity and equality of outcome (income and wealth). In relation to this distinction Crosland formulated a complex notion of equality, which amounted to more than equality of opportunity but at the same time rejected complete equality of outcome as something undesirable and impractical. One consequence of this formulation has been some conceptual confusion. This is certainly true of accounts which have sought to criticise Crosland from the left, where the argument has been presented that all the Croslandite position amounted to was a demand for equality of opportunity (for instance Howell 1976: 193; Crick 
1960). This interpretation is rather surprising given that Crosland goes on to say that the goal of equality of opportunity, though desirable, is insufficient (Crosland 1963: 169). We therefore need to outline what Crosland meant by equality in more detail, not least as it is relevant when we come to discuss why Crosland's ideas ought to be of contemporary relevance.

First, Crosland certainly believed that equality of opportunity was desirable (Crosland 1963: 159-62). He thought that Britain in the 1950s was some way towards equality of opportunity but not as close as other countries such as the USA. The major obstacle to equality of opportunity, defined as the equal chance to compete for social positions, was twofold. First, the existence of a propertied, aristocratic class, upheld through nepotism and the top public schools, acted as a barrier to a true equality of opportunity. Second, the existence of social class divisions and wide inequalities of incomes and wealth acted as a further barrier to equal opportunity. Hence, the definition of equality of opportunity offered by Crosland was a radical one, requiring both lifelong opportunities rather than the one-off form of equality of opportunity that selective secondary schools represented. It would also require significant redistribution and the eradication of social class divisions. Equality of opportunity was therefore desirable, but in the final analysis, 'the limited goal [of equality of opportunity] is not, from a socialist point of view, enough' (Crosland 1963: 169).

Second, then, Crosland sought to place a concern for greater equality of outcome at the centre of the socialist agenda. Indeed, he argued explicitly that although the Labour government from 1945-51 had led to a transformation of capitalism it had not succeeded in introducing socialism since there was still too much inequality. Crosland argued that complete equality in income and wealth was not attractive and impossible and that it had never been a socialist aspiration (with the exception of George Bernard Shaw). However, this did not mean that material inequalities should be tolerated at the levels they were at in the 1950s. It would be difficult, with income tax rates at high levels, to do much by way of further redistribution of income without reducing incentives, but in Crosland's view what was more important was to redistribute wealth and to that end he proposed a range of wealth taxes (see Jackson 2005: 425-9). Moreover, equality could only be a reality in Britain if there was substantial reform to the education system. This would entail a reform of the public schools, in particular allowing for more free places (starting at 25 per cent and rising up to 100 per cent later on), and also a removal of educational selection, with comprehensive schools replacing the existing tri-partite structure of secondary education (grammar, technical and secondary modern schools), which Crosland believed did more than anything else to reinforce social class divisions (Crosland 1963: 188-207). In the 1960s, Crosland served as Secretary of 
State for Education, when he issued a circular that encouraged educational authorities to adopt the comprehensive model of secondary education (Crosland 1982; Jefferys 1999; Price 1999).

There are three further issues which need to be discussed before we move on to examine critical responses to Crosland. The first is the extent to which he presented an ethical argument in favour of equality. Crosland did make several arguments in favour of equality (Crosland 1963: 123-49). The first was the need to avoid social waste; that is, a system in which there were major obstacles to the realisation of equality of opportunity would result in the failure to make the most efficient use of human resources. Greater human talent to fulfil important roles in the economy would result from a more equal society. Second, Crosland argued that equality was desirable as it would overcome social resentment and create a more harmonious form of social relations. Finally, Crosland argued that equality was necessary for the attainment of social justice. People were unable to make best use of their natural endowments in a highly unequal society whereas others benefited disproportionately from the market. Hence, Crosland advocated the idea of the 'rent of ability', which suggested that there needed to be differential wage rates to allow for extra effort and skills for those who completed difficult work that was to the benefit of society, but at the same time did not just leave the extent of these differentials to be determined by the interplay of supply and demand in the free market. Such free-market conditions would on the contrary create unfairness in the distribution of incomes and wealth.

However, the difficulty here is that Crosland, apparently influenced by the ideas of A. J. Ayer (Ayer 1946) concerning the subjectivity of ethical arguments, stated that there was no objective way of determining between competing ethical standpoints (Vaizey 1983: 83). Hence, Crosland effectively suggested that the claims of social democrats against those of economic liberals could not be settled objectively. At the time he was writing, he did not see this as a particular problem, believing that free-market ideas were in any case marginal to public debate, which indeed they were at that time. However, this did place social democrats in a difficult position from the 1970s onwards when the free-market ideas of thinkers such as Hayek (Hayek 1960) directly attacked the central nostrums of social democracy such as equality, social justice and welfare rights. Hence, by the 1970 s social democracy had already been put on the intellectual back foot. We will address this issue below and examine how social democrats responded to this intellectual assault.

The second issue concerns Crosland's view of nationalisation. In making a rigid distinction between ends and means - socialist values and the policies used to realise those values - Crosland was seeking to downplay the 
importance of public ownership. This was no doubt in part for electoral reasons. The Labour Party was in opposition from 1951 and its electoral position deteriorated over the course of the decade. One reason for this, or so it was argued by some electoral analysts and party activists based around Hugh Gaitskell (party leader from 1955), was that nationalisation was losing the party considerable support. However, it was also the case, as has been demonstrated earlier in this chapter, that Crosland sought to provide a clear intellectual analysis of recent economic trends and to show what the most appropriate socialist policies should be in these conditions. He argued that reforms such as the imposition of wealth taxes and comprehensive schools were central to the attainment of equality but further nationalisation was not, due to the divorce between ownership and control in industry mentioned above. This is not to say that he did not see any role for public ownership, but rather to say that it was no longer a central objective for Crosland's socialism.

The final issue to mention in passing before moving on to the criticisms made of Crosland's thesis is that he moved from a very optimistic view of the future direction of British politics in the 1950s to adopting a more pessimistic tone by the end of his life. This was partly due to the onset of economic recession in the 1970s but was also due to his perception of the timidity and orthodoxy of Labour's economic policies in the 1960s, when the objective of increased economic growth was sacrificed in an attempt to preserve the value of the pound and in response to public expenditure cuts in 1975-76 under international pressure (for which see Crosland 1974; Hickson 2005).

\section{Criticisms and responses}

The first significant critique of Crosland's work came from the left. A number of writers in the 1950s and 1970s argued that Crosland had been wrong to argue that control in the economy had split from ownership and that, therefore, public ownership should remain central to socialism. This was true of a number of commentators on the left and others, like John Strachey, who in many other ways had revised their own positions significantly after 1945 (Barratt Brown 1958a, 1958b; Holland 1975; Strachey 1956a, 1956b). Crosland sought to rebut many of these arguments (Crosland 1962, 1974). However, since I have examined this debate in detail elsewhere (Beech and Hickson 2007), for the purposes of this chapter I propose to focus instead on the second significant critique of Croslandite social democracy, from the free-market right.

At the time of the publication of The Future of Socialism, the economic liberal position was marginal. The Institute of Economic Affairs had recently 
been established to fight a rearguard campaign in defence of economic liberalism. The resignation of the Treasury Ministers in January 1958 after failing to convince the Cabinet of the need for spending cuts if anything reinforced the Keynesian consensus. Even in the 1960s, Powellism was essentially a protest against the political establishment. It was only with the election of Margaret Thatcher as leader of the Conservative Party in 1975 that economic liberalism finally came to influence elite opinion. The most powerful part of the economic liberal critique of social democracy was the philosophical case put by Hayek. Space does not allow for a detailed examination of Hayek's arguments (see Hoover and Plant 1989; Barry 1987), but it is possible to list the main criticisms he made against social democracy. Hayek sought to reject the central objectives of social democracy. First, he argued that it was simply wrong to talk of social justice since this was a 'mirage'. Justice concerned only the intentional consequences of human action. Since people did not intend to harm others by making them unemployed, poor, and so on through the pursuit of their own interests in the market they could not be deemed to have acted unjustly. Moreover, Hayek added, the idea of a positive conception of liberty in which the state would provide through welfare provision the resources required to allow people to realise their objectives was a false definition of liberty; true liberty ought to be seen only as freedom from coercion. People were free so long as they were not intentionally coerced. The idea of equality was rejected by Hayek on the grounds that it was impossible to achieve. Since even social democrats had rejected the idea of complete equality of outcome there was in fact no coherent way of determining how resources should be redistributed. There was merely a set of competing principles of distribution with no way in a pluralistic society of deciding objectively between them. Finally, the idea of welfare rights was rejected on the grounds that they were resource dependent and since resources were limited there was no way of guaranteeing the claims of citizens in demanding welfare provision. These arguments, when combined with a range of economic theories such as monetarism, sought to restrict the freedom of government action in terms of economic policy that Keynesian theory had effectively provided, constituting a powerful intellectual challenge to the revisionist paradigm within social democracy.

Added to this theoretical critique of social democracy was an empirical one, which argued that social democracy had undermined economic efficiency. The argument was that the taxation and regulatory measures desired by social democrats to meet their social policy objectives had undermined economic growth, leading ultimately to the decline of the British economy since 1945. On this account, social democrats had failed to understand the nature of markets. This criticism from the New Right was in fact rather similar to the Marxist one mentioned above, namely 
that social democracy was flawed since it was not possible to achieve social democratic objectives within a capitalist economy. From the radical left the argument was made that a thoroughly socialist economic policy would have to be adopted, extending state control and nationalisation. For the right, the social democratic advance of the post-war years would need to be reversed, through policies such as privatisation, deregulation and flexible labour markets. The neo-liberal claim was that in turn this would achieve higher rates of economic growth and would therefore allow for the reduction of poverty. Specifically, it was argued that some of the new wealth created would 'trickle down' to the poor. The market was therefore argued to be a more effective method of reducing absolute poverty, even if more inequality would result from a free-market economic policy. These neo-liberal claims - both theoretical and empirical - will be examined in the final section. However, it is first important to consider a more recent criticism of social democracy.

In the 1990s critics of Croslandite social democracy added to these intellectual and economic challenges the argument that 'real world' changes had effectively brought about the 'death of social democracy'. A recent statement of this type has been made by Vernon Bogdanor, who has argued that the Premiership of Tony Blair and the idea of the 'Third Way' essentially marked the attempt by the left to come to terms with social democracy's demise (Bogdanor 2007). The death of social democracy was, he believes, due to several factors, all of which point to the impossibility of applying Crosland's ideas in contemporary conditions. The first was the inability of the central state to control the private sector of the economy after the reforms of the New Right, which significantly transferred powers from the public to the private sector. Second, there has been a dramatic transfer of power from the nation-state in the form of globalisation. Finally, there has been a transfer of power from the nation-state to sub-national government, most obviously in the form of legislative devolution to Scotland and Wales. Hence the central state, which was the main forum through which equality would be achieved for Crosland, has lost power in three directions: outwards, upwards and downwards. In such conditions, Bogdanor argues, there is very limited scope for the introduction of social democracy in Britain, where neo-liberal reforms went further than in many countries. There would therefore seem to be very little scope for a revival of a form of social democracy that is more radical than the one we have witnessed in the twelve years of New Labour government, which although marking some important moves away from Thatcherism (such as the minimum wage, New Deal, redistribution, higher levels of public spending on health and education, and so on), has also seen some important aspects of continuity with the policies and ideas of the previous Conservative administration (most notably the failure to reduce 
substantive inequalities and the continuing emphasis on the use of markets and the involvement of the private sector in public service delivery). If the above analysis is correct, then we may well be able to appreciate why, after a decade of a Labour administration, British public policy still displays elements of economic liberalism. It remains to be seen if a more radical, distinctively social democratic position is attainable.

\section{A future for social democracy}

In the remainder of the chapter, I wish to sketch out how a revised form of Crosland's socialism would look. We need to do three things here. The first is to outline what form a philosophical defence of social democracy against the economic liberal critique ought to take and then go on to apply these ideas to a number of policy issues that have arisen under New Labour. Second, we need to give a Croslandite response to the criticism of social democracy as undermining economic efficiency. Third, we must subject Bogdanor's 'death of social democracy' thesis to critical scrutiny.

Fortunately, the philosophical case for social democracy has been made already by a number of commentators in the 1980s, most significantly by Raymond Plant (Hoover and Plant 1989; Plant 1991, 1996). Plant has provided the most sophisticated counter-argument to Hayek. His ideas influenced a number of senior Labour Party figures in the 1980s, including Roy Hattersley, Bryan Gould and Giles Radice (Hattersley 1987; Gould 1985, 1989; Radice 1989). There are a number of detailed points that Plant makes against the economic liberals and here I will summarise them briefly in a way that responds directly to the points made above detailing Hayek's position.

First, the idea of justice should be seen as referring not just to intentional acts but also to foreseeable ones, hence the criminal offence of manslaughter, which was based directly on foreseeable but unintended consequences. Given that the rise of inequality was predicted by economic liberals - indeed it was deemed to be one of the desirable outcomes of free-market policies then these consequences could be deemed to be a matter of social justice even though they were not intended. Demands for higher welfare expenditure and so forth were a matter of justice as a response to the foreseeable consequences of free-market policies, which generated poverty, unemployment and inequality.

Second, the negative conception of liberty formulated by Hayek freedom defined as freedom from coercion - was erroneous because it failed to understand the nature of liberty. In asking the question what is liberty for, most people would reply that it was necessary in order to be able to do things. Freedom from coercion was therefore necessary, but only as a 
precondition for the exercise of liberty. The idea of freedom should be seen as much closer to the conception of liberty formulated by social liberals and social democrats, with the emphasis on possessing the ability to do things.

The third social democratic principle rejected by Hayek was that of equality. Again, Plant and others sought to defend the idea of equality, as without it the conception of poverty was meaningless. Poverty had to be seen as a relative condition, as it only made sense to determine if someone was in poverty if they were living below the level of income that meant they were unable to exercise the accepted ideas of citizenship in a given society. Poverty meant not just the lack of the means of life but also the lack of sufficient resources to become an active citizen.

Finally, Plant sought to defend the idea of welfare rights, arguing that since all rights were in fact dependent upon finite resources there was no categorical distinction between welfare rights and other forms of rights. Hayek and other economic liberals had been right to stress the competing claims that were made on the distribution of resources but instead of this meaning that the notion of welfare rights had to be rejected completely, Plant said that there was a need to reach a social consensus on what form the pattern of distribution should take.

There are, I think, two issues here which are important to the discussion of the contemporary relevance of Crosland's ideas. The first is the distinction between moral and mechanical reformers made by Peter Clarke (Clarke 1978). ${ }^{3}$ Moral reformers are those who work from the bottom up seeking to convert public opinion, while mechanical reformers are those who seek to work from the top down driving change through executive action and legislation. Crosland was a mechanical reformer in this sense, although as we have noted he did seek to provide a number of arguments in defence of greater equality. The point is that it was not enough to say that a belief in equality is ultimately subjective. When the intellectual and ethical challenge to social democracy came in the 1970s and 1980s in the form of economic liberalism sufficient numbers of people voted for the Conservative Party and social democrats found it difficult to provide an ethical defence of their position. Hence, it is necessary to make explicit the case for equality and to argue against economic liberalism in the clear belief that social democracy is ethically superior.

The second issue that is of direct relevance is that revisionists of the $1980 \mathrm{~s}$ such as Plant and Hattersley placed significant emphasis on equality, and defined it as something more than equality of opportunity. ${ }^{4}$ The definition of equality was one much more akin to that formulated by Crosland in The Future of Socialism and in fact is one that constitutes something which is ethically distinctive from equality of opportunity. This is the central value difference between traditional and modernising social democrats. In all 
accounts of those who have expressed sympathy for a modernised, New Labour-style social democracy, the idea of equality is one that is restricted to equality of opportunity, as Plant has made clear (Plant 1999). For traditional social democratic critics of New Labour this restriction of equality to equality of opportunity constitutes a fundamental value shift. Hence, Crosland's emphasis on the centrality of equality for social democrats comes to have particular significance when we examine the more contentious aspects of New Labour's domestic policy agenda.

Here a range of issues could be discussed and I will briefly mention only three: income tax, welfare reform and schools reform. In terms of income tax, New Labour refused for largely electoral reasons to pledge to increase the top rate of income tax or to introduce a new higher rate until forced to do so by the economic situation. This raises issues in terms of the ends-means distinction made by Crosland and other post-war revisionists. Crosland maintained that there was a rigid distinction between ends and the policies used to realise those ends. In some accounts of modernised social democracy income tax is therefore one of several means available to achieve redistribution. There has certainly been substantial redistribution of income since 1997, with increases in taxation falling mainly on the top 10 per cent of income earners and extra welfare expenditure going mainly to poorer pensioners and families with young children. However, at the same time the incomes of the richest have continued to increase. The result of this is that the gap between rich and poor remains broadly the same as the level it was in 1997 (Stewart 2007). If the gap between the rich and the poor is deemed to be important, as it was to Crosland and other social democrats until the advent of New Labour, then it would seem that income tax is the only viable strategy for creating a more equal and fair distribution of income. Hence, rather than being one means among many, income tax can better be regarded as an indispensable means for social democrats. The proposal to create a 50 per cent income tax rate for those earning over $£ 100,000$ per annum made by the Fabian Commission on Taxation and Citizenship should be seen as a necessary means for social democrats to create a fairer and more equal society (Fabian Society 2000). Similarly, the emphasis that Crosland placed on the redistribution of wealth should also lead us to think that New Labour has revised ends and not just means in its reluctance to drive through fiscal measures to redistribute wealth, the distribution of which is even more unequal than is the case with income.

The other areas mentioned above - welfare reform and schools reform - can be taken together since they both concern the most appropriate way to reduce inequality. The proposals of New Labour have been to extend choice in both welfare services - especially the National Health Service and in schools. Foundation hospitals, the attempt to create something akin 
to the internal markets created by the Conservatives in the NHS, and the creation of city academies and specialist schools are all attempts to create more choice for patients and parents. However, a concern expressed by traditional social democrats against some or all of these reforms is that they will reinforce the inequalities present in society more generally. This is not so much a matter of income and wealth inequality, at least not directly, as public services would still be provided free at the point of use. However, certain groups in society - what for convenience we could term the middle classes - would be better able to exercise the choices presented to them due to having a greater awareness of the options available and by being able to voice their preferences more effectively than others. In a recent attempt to justify such policies, Rajiv Prabhakar has argued that inequality is a feature of existing public services (Prabhakar 2006). This is no doubt the case and he has presented sufficient evidence to demonstrate this. However, the extension of market mechanisms, which underpin most recent reforms, would seem to egalitarians to be more not less likely to create further inequalities in public services and it is the responsibility of those who argue for such reforms to show how they would help to reduce inequality (for further discussion, see Chapter 8 in this book). Hence, Crosland's egalitarian emphasis is particularly relevant in terms of public services, where any reform must be assessed in terms of its impact on inequality.

Second, when we turn to the empirical argument presented by neoliberals - that a free-market policy framework could best increase the rate of economic growth and reduce absolute poverty through the 'trickle-down' effect - we can again see that it is possible to defend the social democratic position. First, neo-liberals claimed that overall economic growth would be higher under free-market policies. There is some truth in this in that economic growth in Britain was higher in the 1980s than in the 1970s. Indeed, this could hardly be otherwise given the poor condition of the British economy in the 1970s. However, economic growth was higher in the 1950s and 1960s than it was in the 1980s and therefore we can see that there is no direct relationship between social democracy, neoliberalism and the rate of economic growth. In the period 1962-72, the rate of growth of GDP was above 2 per cent. In the 1980s, it was under 2 per cent. The second empirical claim - that the market is more effective at reducing poverty levels is proven false when one looks at the increased level of poverty in Britain the 1980s. The average increase in the incomes of the poorest 10 per cent of the population was significantly higher in the postwar period than in the 1980s, whereas the proportion of those considered to be living below the poverty line increased substantially in the $1980 \mathrm{~s}$ (statistics in this paragraph are from Budge et al. 1998: 22-5; for further discussion, see Hoover and Plant 1989: 155-84). 
Third, we must consider the purported death of social democracy. As mentioned above, a recent articulation of this viewpoint has been made by Bogdanor, who stresses the ways in which power has shifted upwards, outwards and downwards leaving the central state effectively hollowed out and unsuitable as a mechanism for the introduction of social democracy. Certainly, the recent transfer of power away from the central state should not be simply ignored and does make the pursuit of social democracy more difficult. However, there are a number of points that can be made here. First, in terms of the transfer of power outwards from the state, it can be observed that the privatisations of the 1980s were accompanied with regulatory regimes and so it is possible to talk of a regulatory state in which central government retains substantial powers over the economy (Moran 2003). Moreover, privatisation, although initially popular in the 1980s, became more controversial in the 1990s and it may be possible to build a social consensus for limited re-nationalisation measures in cases such as the railways where very high levels of public sector investment have not necessarily resulted in improved performance. Equally, in areas such as public-private partnerships and private finance initiative schemes the claim made by New Labour to do what works can seem more doubtful now. Gordon Brown did talk of a "public interest test' in determining the level and form of private sector involvement and although nothing has been done to develop this, it would seem a particularly fruitful idea to build upon. The idea that power has been transferred upwards from the nation-state in the form of globalisation can also be questioned, since the statistics available are contentious and some commentators have doubted the extent to which the process undermines the ability of nation-states to at least influence the activities of large corporations (Hirst and Thompson 1999). Similarly, the transfer of powers downwards to sub-national government should not lead us to assume that the state lacks sufficient powers to introduce radical reforms from the centre. The experience of devolution in fact shows us that where legislative powers have been decentralised there has been more scope for the implementation of social democratic measures not less, as is the case in Wales and Scotland.

Hence two points can be made by way of conclusion - that Crosland's position is more relevant than may at first be thought and second that such a position allows for a more radical formulation of social democracy than the one we have witnessed in Britain since 1997. In terms of the ongoing relevance of Crosland's ideas, this essentially revolves around the definition of equality that he formulated and its centrality to the social democratic project. Equality ought to involve more than a commitment to equality of opportunity, even an extensive notion of equality of opportunity as we 
have witnessed with New Labour, since without the correction of unfair market outcomes at the top and the bottom of the income scale, social injustice will result. Similarly, without an overriding concern with equality, public services involving the heavy use of market mechanisms will result in injustice. In terms of the radicalism of Crosland's ideas in contemporary conditions we should perhaps not be surprised. Richard Crossman, Crosland's intellectual rival on the left of the Labour Party for much of the 1950s, was prepared to admit in private that Crosland's arguments were radical than many realised: 'They are diabolically and cunningly left wing and Nye (Bevan) should have been clever enough to think them up' (quoted in Jefferys 1999: 63). Indeed, Crosland did not just attack those on the left, but also criticised the moderates on the right of the Labour Party. As Susan Crosland has commented: 'His tough-mindedness made him impatient with the right's caution, its tendency to woolly-mindedness. In later years as many on the right became readier to compromise with existing social structures, his impatience bordered on hostility. He said he was an egalitarian and he meant it' (Crosland 1982: 71).

\section{Notes}

1 Crosland has been subject to a number of studies including those by Susan Crosland (1982), Kevin Jefferys (1999), David Reisman (1997a, 1997b), and the volumes edited by David Lipsey and Dick Leonard (1981) and Leonard (1999). The author has also written at more length on a number of the issues discussed in this chapter in Beech and Hickson (2007) and is grateful to Simon Griffiths and the editors of this volume for their comments on an earlier draft of this chapter.

2 This was the essence of his critique of the Gotha Programme formulated by the German social democrats. See Marx [1875] (1938).

3 A similar view of Crosland's social democracy was taken by David Marquand (1996).

4 For a recent account of Hattersley's thought on these issues and the influence of Plant on 1980s Labour Party revisionism, see Beech and Hickson (2007).

\section{References}

Ayer, A. J. (1946) Language, Truth and Logic (London: Gollancz). Barratt Brown, M. (1958a) 'The insiders', Universities and Left Review, 3, winter.

Barratt Brown, M. (1958b) 'The controllers', Universities and Left Review, 5, autumn.

Barry, N. (1987) The New Right (London: Croom Helm).

Beech, M. and Hickson, K. (2007) Labour's Thinkers: the Intellectual Roots of Labour from Tawney to Gordon Brown (London: I.B. Tauris). 
Berle, A. and Means, G. (1932) The Modern Corporation and Private Property (New York: Macmillan).

Bernstein, E. [1899] (1993) The Preconditions of Socialism, ed. by H. Tudor (Cambridge: Cambridge University Press).

Bogdanor, V. (2007) 'Social democracy', in A. Seldon (ed.), Blair's Britain 19972007 (Cambridge: Cambridge University Press).

Brown, G. (2006) 'Foreword', in C. A. R. Crosland, The Future of Socialism (London: Constable).

Budge, I., Crewe, I., McKay, D. and Newton, K. (1998) The New British Politics (London: Pearson).

Burnham, J. (1942) The Managerial Revolution (London: Putman).

Clarke, P. (1978) Liberals and Social Democrats (Cambridge: Cambridge University Press).

Crick, B. (1960) 'Socialist literature in the 1960s', Political Quarterly, 31 (3).

Crosland, C. A. R. (1956) The Future of Socialism (London: Cape).

Crosland, C. A. R. (1962) The Conservative Enemy (London: Cape).

Crosland, C. A. R. (1963) The Future of Socialism (New York: Schocken).

Crosland, C. A. R. (1974) Socialism Now and Other Essays, ed. by D. Leonard (London: Cape).

Crosland, S. (1982) Tony Crosland (London: Cape).

Fabian Society (2000) Paying for Progress: a New Politics for Tax and Public Spending (London: Fabian Society).

Gould, B. (1985) Socialism and Freedom (Basingstoke: Macmillan).

Gould, B. (1989) A Future for Socialism (London: Cape).

Hattersley, R. (1987) Choose Freedom: the Future for Democratic Socialism (London: Joseph).

Hayek, F. A. (1960) The Constitution of Liberty (London: Routledge).

Hickson, K. (2005) The IMF Crisis of 1976 and British Politics (London: I.B. Tauris).

Hirst, P. and Thompson, G. (1999) Globalisation in Question (Cambridge: Polity).

Holland, S. (1975) The Socialist Challenge (London: Quartet).

Hoover, K. and Plant, R. (1989) Conservative Capitalism in Britain and the United States: a Critical Appraisal (London: Routledge).

Howell, D. (1976) British Social Democracy (London: Croom Helm).

Jackson, B. (2005) 'Revisionism reconsidered: "Property-owning democracy" and egalitarian strategy in post-war Britain', Twentieth Century British History, 16 (4).

Jay, D. (1962) Socialism and the New Society (London: Longmans).

Jefferys, K. (1999) Anthony Crosland: a New Biography (London: Cohen).

Jenkins, R. (1953) Pursuit of Progress (London: Heinemann).

Leonard, D. (ed.) (1999) Crosland and New Labour (Basingstoke: Macmillan).

Lipsey, D. and Leonard, D. (eds) (1981) The Socialist Agenda: Crosland's Legacy (London: Cape).

Lukes, S. (1977) 'Socialism and equality', in S. Lukes, Essays in Social Theory (Basingstoke: Macmillan). 
Marquand, D. (1996) 'Moralists and hedonists', in D. Marquand and A. Seldon (eds), The Ideas that Shaped Postwar Britain (London: Fontana).

Marx, K. ([1875] 1938) Critique of the Gotha Programme (London: Lawrence \& Wishart).

Moran, M. (2003) The British Regulatory State: Hyper-Modernism and HyperInnovation (Oxford: Oxford University Press).

Plant, R. (1991) Modern Political Thought (Oxford: Blackwell).

Plant, R. (1996) 'Social democracy', in D. Marquand and Seldon, A. (eds), The Ideas that Shaped Postwar Britain (London: Fontana).

Plant, R. (1999) 'Crosland, equality and New Labour', in D. Leonard (ed.), Crosland and New Labour (Basingstoke: Macmillan).

Prabhakar, R. (2006) Rethinking Public Services (Basingstoke: Palgrave).

Price, C. (1999) 'Education secretary', in D. Leonard (ed.), Crosland and New Labour (Basingstoke: Macmillan).

Radice, G. (1989) Revisionism: Labour's Path to Power (Basingstoke: Macmillan).

Reisman, D. (1997a) Anthony Crosland: the Mixed Economy (Basingstoke: Macmillan).

Reisman, D. (1997b) Crosland's Future: Opportunity and Outcome (Basingstoke: Macmillan).

Stewart, K. (2007) 'Equality and social justice', in A. Seldon (ed.), Blair's Britain 1997-2007 (Cambridge: Cambridge University Press).

Strachey, J. (1956a) Contemporary Capitalism (London: Gollancz).

Strachey, J. (1956b) 'The new revisionist', New Statesman and Nation, 6 October.

Vaizey, J. (1983) In Breach of Promise (London: Weidenfeld \& Nicolson).

Wickham-Jones, M. (2007) 'The Future of Socialism and New Labour: an appraisal', Political Quarterly, 78 (2). 


\title{
The rhetoric of redistribution ${ }^{1}$
}

\author{
Ben Jackson
}

Hobson, lecturing on economics last night on the BBC, referred to the revolution which had occurred in our society by the imposition of taxes upon wealth, \& the heavy death duties which prevented it from being passed on. And D. [Lloyd George], looking at me significantly, pointed his finger to his own breast, meaning: I did it.

(Lloyd George: a Diary by Frances Stevenson, entry for 29.10.1934, quoted in Clarke 1974: xxxiv)

\section{Introduction}

The historic distributive achievements of social democracy - the welfare state, the progressive taxation of income and wealth, the regulation of the labour market - were not simply the fruit of social pressures and the expertise of sympathetic intellectuals. The implementation of these reforms also required the creative exercise of power by adept political leaders. These leaders persuaded voters of the value of the welfare state or progressive taxation in accessible, even demotic, language and constructed electoral coalitions that would support parties committed to these measures. But this great progressive tradition of public oratory on behalf of the poor and underprivileged has been absent from politics in Britain and the United States in recent years. Both the Labour and Democratic parties conspicuously struggled to articulate a compelling public case for reducing poverty or narrowing economic inequality when they returned to office in the 1990s. In Britain, Labour's adoption of centrist rhetoric after 1994 famously proved compatible with so-called 'redistribution by stealth': a concerted attempt to engineer non-negligible but unpublicised improvements in the incomes of the working poor. However, these welcome measures have not reversed the large economic inequalities created during the 1980s (see Brewer et al. 2008), and Labour's underlying commitment to a fairer Britain 
proved to be less than robust when confronted in 2007 with a concerted Conservative counter-attack over inheritance tax. Arguments in favour of inheritance tax apparently eluded leading Labour politicians at this crucial conjuncture. Similarly, in the United States, the Democrats were unable to find a convincing answer to the Republican repeal of the estates tax in 2001. As a result, the Democrats comprehensively lost the argument over whether or not it is fair to tax inherited wealth (for the gory details, see the indispensable Graetz and Shapiro 2005). Hovering in the background of these and similar debates in other nations lurks the widely discussed proposal to abolish progressive taxation of income and wealth altogether and replace it with a flat tax (see e.g. The Economist 2005). Although at present this seems to be a distant prospect, if recent political history teaches us anything it is that the extreme libertarian think-tank pamphlet of today can very quickly become the government policy of tomorrow.

The formulation of an attractive public discourse about economic redistribution is therefore a matter of some urgency for parties of the left. On it rests the defence of the hard-won achievements of the past and the mobilisation of popular support for fresh initiatives aimed at reducing poverty and economic inequality. But how are such political arguments to be constructed? What sort of language can legitimise the transfer of resources from one group of citizens to another? In answering these questions, one instructive source of information is likely to be historical. After all, at certain points in the past, radical politicians did manage to articulate and win arguments about economic redistribution. In this chapter I will provide some evidence about how this was done. I will also argue that contemporary perceptions of this genre of political rhetoric are often inaccurate: modernisers who have laboured to renew the popular appeal of leftwing parties see 'old' social democratic language as unnecessarily alarmist to middle-income voters and premised on an anachronistic appeal to an ever-diminishing working class. The evidence assembled in this chapter suggests that the historical premises of this argument are in fact mistaken. The actual rhetoric of redistribution deviated in important respects from the interpretation of it deployed in present-day political polemics, and this in turn raises the possibility that earlier styles of progressive rhetoric might yet be renovated for use in contemporary political arguments.

To substantiate these points, I will identify certain important features of the rhetoric used in the past to argue for progressive taxation, welfare programmes, the regulation of the labour market, and other policy measures intended to lighten the burdens of the poor by increasing burdens on the better off. For the sake of brevity, I will refer to these measures collectively as 'redistribution'. I will draw on evidence from three important episodes of progressive policy-making and electioneering: first, the rhetoric used to 
justify 'new liberal' welfare reforms and fiscal policy in Edwardian Britain, in particular the speeches of Lloyd George; second, the political discourse of the New Deal in the United States in the 1930s, especially speeches and broadcasts by Franklin Roosevelt; and, finally, proposals in Britain during and after the Second World War about the character of post-war reconstruction, as advocated by prominent politicians in the Labour Party, and also by other influential figures such as William Beveridge. In spite of the differences between these episodes of social reform (and in particular between the British and American cases), I will nonetheless maintain that their rhetorical justification exhibited certain illuminating similarities. ${ }^{2}$

I must stress at the outset that this chapter is expressly interpretive rather than quantitative in its approach. It identifies the ideological structure and animating political strategy of redistributive political discourse through the methods of textual analysis familiar to scholars of political thought. ${ }^{3}$ Implicit in this approach is the assumption that, while the scrutiny of principles of social justice under ideal conditions is an indispensable aspect of political theory, it is equally important to investigate how political language is used strategically, as a weapon in partisan political warfare and the struggle for power. Such strategic considerations are vital because they identify important constraints that will ultimately govern the character of the arguments for social justice suitable for our non-ideal world (here I draw my inspiration from work such as Freeden 1996; Skinner 2002; Stears 2005). One consequence of this focus on political thought is that the causal claims made in this chapter are very limited: at no point do I want to suggest, for example, that suitably persuasive rhetoric is, or was, in itself sufficient to engineer public support for economic redistribution regardless of prevailing social and economic circumstances. Instead, my working assumption is simply that the public arguments of politicians have at least some influence over the outcome of policy debates and the mood of public opinion. I leave this relatively uncontroversial assumption undefended in order to focus on my specific aim in this chapter, which is simply to clarify the character of political rhetoric in the past rather than to assign it any precise causal role in bringing about political change. What is presented here is therefore a necessary preliminary exercise to a more fine-tuned discussion of the part played by rhetoric in either past or present distributive controversies.

In this spirit, I will identify three important aspects of redistributive rhetoric: first, its critique of prevailing distributive patterns via an appropriation of a populist understanding of the 'public interest'; second, the specific political ideals that redistribution was said to advance; and third, the assumptions about political agency that underpinned this rhetoric and that it helped to disseminate to a wider public. 


\section{Economic royalists versus Oliver Twist: redistribution and the public interest}

Rhetoric is the art of persuading a particular audience. In Aristotle's words, it is 'the faculty of observing in any given case the available means of persuasion'. On Aristotle's account, the available means will not always be logical, but will rather be a combination of the credibility of the speaker's character, the emotions the speaker arouses in the audience, and the reasoned arguments that the speaker can marshal. Through this combination of ethos, pathos and logos, argued Aristotle, political arguments are fought and won (Aristotle 1984, Bk 1, Ch. 2: 2155). Political rhetoric therefore does not succeed by the strength of its logic alone: it prospers by packaging, compressing and sometimes even bypassing logical reasoning so that arguments are rendered accessible and plausible to a target audience. The first characteristic of the rhetoric of redistribution I want to examine offers an apt illustration of the role played in political persuasion by both emotional appeals and the personal credibility of a speaker: the critique mounted by progressive politicians of the prevailing distribution of wealth and opportunity. In essence, this critique drew a sharp dividing line between the interests of the rich and the interests of the community as a whole.

The initial step along this road was simply to use emotive terms to juxtapose the parlous state of the poor with the privilege enjoyed by the wealthy. For example, Lloyd George contrasted 'the profligate extravagance with which land by the square mile is thrown away upon stags and pheasants and partridges' with 'the miserly greed with which it is doled out for the habitations of men, women and children' (17.10.1910, London, BT: 337). Crucial to the liveliness and power of this language was the sparing use of statistical information. Certain striking facts were undoubtedly highlighted, but not at the expense of memorable narratives about the fate of particular individuals or social groups. Popular support for redistribution was initially elicited by inviting the voters to empathise with the deprivations suffered by the poor and the needy, sometimes by drawing on a common stock of cultural memories and references. Herbert Morrison defended the record of the 1945 Labour Government by contrasting Labour's reforms with the 'sad picture of the bad old days' disclosed in the recently released film of Oliver Twist and with his own memories of his childhood:

We have only to recall the drab misery of the back streets of our cities in the last century - the lack of pure water, the sewerage conditions, the employment of young children, the disgrace and crime of poverty, the dark squalor of birth with the ignorant tolerance of death of children and mothers, the slums with their lurid 'pubs', the poverty, destitution and heaped-up misery of it all - to wonder at the change which has taken place and, I think, to be 
thankful that the heart of our people went through it unbroken. (12.7.1948, London, PR: 128-9)

At the Democratic Party National Convention in Philadelphia in 1936, at the height of partisan controversy over the New Deal, speech after speech addressed not only facts but 'the human values far beyond these figures', forcefully contrasting the conditions before Roosevelt's Presidency - when 'destitution walked every street' - with the success of government intervention in ensuring 'that the cheeks of little children shall not grow gaunt' and ending 'starvation, bread lines and soup kitchens'. The authority of these points was often bolstered by biblical references - the New Deal was said to embody the Sermon on the Mount, for instance, or to answer the question 'Am I my brother's keeper?' (PDNC: 50, 281, 229, 214, 225, 51; see also $187,230,244,255-6,276,281-4)$. The public discussion of poverty and its associated hardships in this direct, home-spun fashion carried as much and perhaps even more weight in public debate than the use of statistical evidence, since it was often more effective at attracting the emotional loyalties of the public and drew on the authority of certain widely known cultural references. ${ }^{4}$

However, this was only the first step in arousing popular outrage at social injustice - much stronger contrasts between rich and poor were also made. Progressive politicians usually deployed two important but cutting redescriptions of the behaviour of certain wealthy citizens and their allies: as 'parasitic' and as 'selfish'. ${ }^{5}$ First, they characterised some of the rich as 'parasitic' since existing property entitlements did not always reward effort. Crudely speaking, some people were said to be rich either because of large capital incomes that expanded without regard to the amount of work performed by the beneficiary or they accrued resources because of various kinds of market-based luck unrelated to productive contribution. As Lloyd George put it, too little attention was given to the problem of 'unemployment amongst the upper classes'. The 'idle rich', he continued, enjoyed 'lives of luxurious indulgence, and a great multitude of others live lives of arduous toil without earning sufficient food and raiment and repose' (17.10.1910, London, BT: 339-40). Inherited wealth was indeed simply 'a fatty degeneration of property', observed the Labour Chancellor of the Exchequer Hugh Dalton as he raised death duties in 1946: such wealth tempted those in receipt of it to 'become lazy and thriftless, unambitious and unenterprising'. ${ }^{6}$ By contrast, it was argued, those on low incomes worked hardest of all and received miserly compensation for their efforts. As Henry Ellenbogen, a Democratic congressman, put it in 1935, the low paid were 'the builders of America', who 'dug its ditches, paved its roads, operated its machines, constructed its buildings' (19.8.1935, Congress, 
in Zinn 1966: 283). ${ }^{7}$ Herbert Morrison even proclaimed that the Labour Party 'stands up for all the useful people' (13.12.1947, radio broadcast, PR: 142). A reciprocal relationship between productive contribution and social rights was therefore central to the justification of economic redistribution: redistributive measures were presented as a just return for the valuable social service rendered by the industrious poor (Freeden 2003: 12-13; White 2003: 214-16, 218).

Second, in addition to suggesting that the behaviour of certain wealthy citizens and their allies was 'parasitic', progressive politicians also argued that the economic and political behaviour of the rich could be 'selfish', since many of them were either directly responsible for the exploitative pay and conditions suffered by the poor or indirectly responsible by opposing remedial political action. The pursuit of self-interest, far from being the praiseworthy quality depicted by the right, was redescribed as sectional behaviour that detracted from the common good. From 1940 onwards, for example, radical populist sentiments coursed through British public debate, with journalists and broadcasters such as J. B. Priestley, George Orwell and Tom Wintringham of the Mirror fiercely criticising the failures of the traditional elites initially in charge of the War effort and shaping the terms of wartime political discussion into one that placed the people's desire for reform at odds with the self-serving agenda of the 'old gang' (Addison 1975: 127-63; Cronin 1984: 122-3). In due course, politicians picked up on these themes. During the 1945 general election campaign, Clement Attlee brusquely rejected the 'pathetic faith' of the Conservatives that 'if every individual seeks his own interest somehow or other the interests of all will be served' and objected to the use of libertarian rhetoric to justify Conservative policy. 'There was a time', Attlee noted, 'when employers were free to work little children for sixteen hours a day', in effect there was 'freedom for the rich and slavery for the poor', and it was only through the action of the state 'that the general public has been protected against the greed of ruthless profit-makers and property-owners' (5.6.1945, radio broadcast, PP: 7, 9; see also Cripps 1946: 20-1, 33, 34).

To ruthlessness and greed was added subversion of the democratic process. In his scintillating acceptance of the Democratic presidential nomination in 1936, Roosevelt drew on the struggle for American independence to establish a parallel between the British royalists who had tried to deny American democracy and the 'economic royalists' who now threatened economic and political life. The wealthy, 'the privileged princes', were 'thirsting for power' and trying 'for control over government itself'. This 'small group' had 'an almost complete control over other people's property, other people's money, other people's labour - other people's lives'. In short, the United States faced 'economic tyranny' from 'the forces of selfishness 
and of lust for power' (27.6.1936, Philadelphia; 31.10.1936, New York; both in FDR vol. 5: 232-3, 568-9). ${ }^{8}$

While the juxtaposition of the very different lives of the rich and poor therefore aimed at winning public support by arousing popular emotions - sympathy for the poor and indignation at the indifference of the rich the personal authority of the speaker also played a significant role in the persuasive appeal of this rhetoric. The very fact that senior political leaders were criticising the rich and powerful, and speaking sympathetically about the hardships faced by the poor, made these sentiments credible in a way that could not be matched by radical activists or political outsiders who might make similar points. The full authority of the offices of the president of the United States or the British Prime Minister and Chancellor of the Exchequer were placed behind this critique of economic inequality, granting importance to political ideas that might otherwise have seemed dangerously radical or impracticable. ${ }^{9}$ 'The President wants you to join a union', ran the famous slogan of the American union leader John L. Lewis, after Roosevelt's National Industrial Recovery Act had been passed into law in 1933, complete with its pro-union clause 7a (Gerstle 1989: 127-8; Anderson 1990: 283-8).

As we have seen, these powerful political sponsors of the rhetoric of redistribution explicitly appropriated the discourse of the public interest, the common good and even patriotism, but they defined these ideas - 'the public', 'the nation' - in populist terms, as synonymous with the material needs of, as Roosevelt put it, 'the average man' (e.g. FDR vol. 4: 471; FDR vol. 5: 39, 211). In Britain, this style of rhetoric can be seen as a development from Gladstone's famous drawing of the electoral battle lines as 'the classes against the masses' or 'the classes against the nation' (Matthew 1995: 94-8). Gladstone had contrasted the sectional interests of privileged elites with the classless outlook of the nation as a whole largely in the context of non-economic issues such as parliamentary reform or the abolition of slavery. Later new liberals and socialists in turn sought to contrast the sectional, class-based economic behaviour of the rich with a classless national interest based upon the material needs of the ordinary citizen. In the United States, such rhetoric drew on a perennial republican theme, deeply entrenched in American political culture: the danger posed to the common good of the republic by the accumulation of power and influence in the hands of a self-centred minority (Gerstle 1989: 177).

In order to make this populist definition of the public interest more persuasive, advocates of redistribution stressed that their proposals expressed the traditions, values and interests of their national communities; that, among other things, redistribution expressed the fairness and solidarity of the national character. Beveridge argued that the introduction of a 
national minimum was 'a peculiarly British idea', and he added that his report on social insurance should not be seen as his own work but as an expression of the British people's deepest convictions: the Beveridge Report was 'the British people become articulate' (3.3.1943, London, PS: 143). 'We are not going to measure the strength of great powers only in their material forces', argued the young Winston Churchill in defence of Lloyd George's 'People's Budget' in 1909. In order for Britain 'to remain great and famous in the world' it was essential to promote 'the vigour and health of its population' and to deal with 'the present social and industrial disorders'. If Britain did not do so, he warned, 'our country will remain exposed to some fatal dangers against which fleets and armies are of no avail'. ${ }^{10}$ Roosevelt's attack on 'economic royalists' embedded economic redistribution within the broader narrative of the history of the republic. Opponents of the New Deal were now depicted as un-American, a point Roosevelt later made more explicit when he linked the American Revolution, a struggle for 'democracy in taxation', with the introduction of a more progressive income tax structure during the New Deal. Taxation according to ability to pay, argued Roosevelt, was 'the American principle', and the New Deal had 'Americanised the tax structure' by introducing greater progressiveness. As a result, Roosevelt argued that his administration had created 'a safer, happier, more American America', offering 'fidelity' to the true meaning of 'Americanism' (21.10.1936, Worcester, MA; 30.10.1936, Brooklyn, NY; 29.9.1936, Syracuse, NY; all in FDR vol. 5: $523-7,562,383){ }^{11}$

This social patriotism gave a clearer content to the rhetorical contrast between the common good and sectional interests. The rich and powerful were said to be benefiting themselves at the expense of their compatriots, while particular policy measures, such as a more progressive tax structure or the Beveridge Report, were portrayed as expressive of the fairness and solidarity inherent in the national character. National cultures and histories, as well as more straightforward arguments about enhancing the strength and power of the nation, were also recruited to the cause. As the Liberal MP Leo Chiozza Money sarcastically remarked in the parliamentary debate on the 'People's Budget', the opposition of the wealthy to higher taxation suggested that "we shall need a new definition of the word patriot: "Patriot: a person who won't pay"'. ${ }^{12}$

The ubiquity of this discourse of social patriotism challenges certain $a$ priori assumptions about the character of traditional progressive rhetoric. By invoking the nation, progressive politicians spoke about an identity that transcended class loyalties and contrasted a shared sense of community with the privilege enjoyed by a minority. In the speeches of Lloyd George, Roosevelt and others, the behaviour of the rich was presented as conflicting 
with the values of the nation rather than with the interests of the working class. Progressive politicians therefore did not disparage the ambitions of working families who sought to improve themselves and they spoke in terms designed to construct a political coalition between low- and middleincome voters against the wealthy minority. ${ }^{13}$ Once the welfare state was put into operation, argued Herbert Morrison, 'the middle classes as well as the working classes will have reason to bless these services' (13.12.1947, radio broadcast, $P R: 142$ ). For better or worse, the social democratic left has usually eschewed an electoral strategy and public ideology straightforwardly founded on an appeal to working-class interests.

\section{The lexicon of redistribution}

I have so far focused predominantly on the role played by emotional appeals and personal authority in shaping the rhetoric of redistribution. I have shown how powerful progressive politicians sought to arouse popular indignation at the prevailing distribution of wealth and opportunity, and how they embedded their criticisms in a discourse of the public interest and social patriotism. In the second part of this chapter I will focus more directly on the reasoned arguments that progressive politicians articulated in their oratory and, in particular, on the political ideals that they claimed redistribution could advance.

Two points should be stressed here. First, explicit references to material equality were handled rather gingerly. For example, when Roosevelt mentioned economic redistribution he would typically talk about sharing wealth 'more widely', or even more democratically, rather than more equally, and would often refer to 'concentrated' wealth rather than wealth inequality (e.g. FDR vol. 4: 271; FDR vol. 5: 162, 475, 521). Arguments directly emphasising the goal of material equality were not used with any frequency. Some of the politicians discussed here were simply not that comfortable with explicitly egalitarian language; others were, but probably judged that egalitarian language would be politically ineffective, since it was too controversial and offered an easy target for political opponents.

The second point to note about the political ideals invoked to support redistribution is that progressive politicians pressed into service a cluster of values judged to be more popular than the seemingly polarising goal of 'economic equality'. Many examples could be given here, but three stand out as particularly important: opportunity, security and fairness. In mentioning these words, it is of course hard to avoid summoning up the shades of Tony Blair or Bill Clinton. However, the words themselves are obviously open to diverse interpretations and the way in which they were used by 
politicians such as Lloyd George or Roosevelt was different from their use by present-day third wayists.

First, classic examples of redistributive public policy were presented as offering 'opportunity' to sections of the community previously denied it. The sheer elasticity and ambiguity of the concept of 'equal opportunity' can be an asset in political argument, since its apparently uncontentious, positive connotations command a broad public appeal. For example, 'opportunity' offered a link to the strong form of economic reciprocity discussed earlier: wealth and security were presented as rewards for, in Attlee's words, the 'hard work' of the majority, not the parasitic idleness or special privileges of the rich (7.2.1946, House of Commons, PP: 98). The provision of material resources and social services to the poor, either through social insurance, full employment policies or a more progressive tax structure, was in itself said to offer 'opportunity'. Since 'one cannot teach hungry children, or children who return each night to squalid homes', economic resources were necessary for individuals to make the most of their lives. The provision of decent jobs would extend the "opportunity of honourable, useful service' to the whole community (Beveridge 1944b: 6, 5). Crucially, this desire to spread 'opportunity' was not discussed as if it were purely a matter of fostering social mobility for a talented few. The bewitching image of a ladder out of poverty was not what progressive politicians had in mind. The new American ideal, announced Roosevelt, was not 'the dream of the golden ladder - each individual for himself', but rather of 'advancement ... along a broad highway on which thousands of your fellow men and women are advancing with you' (24.8.1935, radio broadcast, FDR vol. 4: 339). Stress was laid on collective rather than individual mobility, and the elimination of economic hardship was understood to be the necessary precondition of securing this goal.

Second, in the early twentieth century, security emerged as an authoritative word in the redistributive lexicon. Politicians often focused their rhetorical appeal on the concrete vulnerability of individuals and families to economic risk: the possibility of poverty and of hardship as much as actual poverty and hardship was a dominant theme in pro-welfare state rhetoric (and in welfare state political thought more generally: see Freeden 2003: 13-16). Lloyd George succinctly expressed the problem: 'Precariousness of work leads to the servitude of the worker. Certainty of work means freedom' (23.3.1910, London, BT: 302). The appeal of redistribution was that it would alleviate the distress caused by uncertainty about one's economic fate. 'Worry and anxiety are as inimical to health and happiness as the actual physical conditions of poverty', argued Attlee (7.2.1946, House of Commons, PP: 98). Social insurance, added Roosevelt, would make families 'free from this ever-present fear', enabling them to feel 'confidence' about 
their future (13.10.1936, Wichita KA, FDR vol. 5: 460). The very introduction of the terms 'social security' and 'social insurance' into popular political discourse in itself helped to drive this point home, conjuring up the need for collective precautions against the inherent risks of market economies. Security could only be guaranteed, went this argument, when the impact of economic risk was dampened by the entitlement of every citizen to a minimum income and access to social services (see e.g. FDR vol. 5: 574).

The discursive salience of 'security' was obviously related to the economic hardships and uncertainties that shaped voters' social experience: the depression of the 1930s, for example, was clearly the central reference point throughout New Deal rhetoric and in British political debates during and after the Second World War. But it would be wrong to conclude that the rhetorical force of this concept was relevant only to this particular period. Although the Great Depression was certainly a particularly stark instance, it would be odd to suggest that there was not a more general pattern of instability to be discerned in the operation of capitalist economies. In our own time, the salience of security also opens up interesting rhetorical connections that could be made between economic and international security, a link earlier made explicit by Roosevelt during the Second World War. ${ }^{14}$

Connected to these concrete objectives - 'securing for all citizens equal opportunity and equal security so far as human intelligence can achieve it' - was the third, and more abstract, ideal of fairness (H. Lehman, PDNC: 262-3). Fairness or social justice was regularly employed as a justification for equalising opportunities and security and as a more general demand for 'fair shares' for all. When used in political rhetoric, fairness concerned both the distribution of resources according to need and the allocation of burdens in proportion to the individual's capacity to contribute. In this first sense, fairness suggested an order of distributive priority. As Roosevelt suggested, 'the ambition of the individual to obtain for him and his a proper security, a reasonable leisure, and a decent living throughout life, is an ambition to be preferred to the appetite for great wealth and great power' (4.1.1935, message to Congress, FDR vol. 4: 17). Politicians argued that it was unjust to expect families to cope with great hardship when resources were available to assist them; it was only fair for the state to ensure that everyone enjoyed a minimum income. The demand for a national minimum was therefore stressed at the expense of more specifically egalitarian objectives (e.g. PS: 149). This goal, although more moderate than the radical egalitarianism sometimes ascribed to these political debates, seems to have reflected (and probably also influenced) popular perceptions of social fairness in the United States and Britain in the first half of the twentieth century (see e.g. Anderson 1990: 285-9, 315; Thane 1984: 899-900). But the 
cry for fair shares also made demands of public opinion. It called for the imaginative sympathy of more fortunate listeners, asking them to picture themselves placed in the straitened conditions of the poor and needy, and to recognise the role of luck in determining their place in the class structure. Fairness therefore also raised a second issue, the requirement of a greater contribution from those who were well-off. One objective of his 'People's Budget', said Lloyd George, was to place 'burdens on the broadest shoulders' and to ensure 'that wealth shall pay its fair share'. As he elaborated: 'There are many in the country blessed by providence with great wealth, and if there are amongst them men who grudge out of their riches a fair contribution towards the less fortunate of their fellow-countrymen they are very shabby rich men' (30.7.1909, Limehouse; 9.10.1909, Newcastle; BT: 156, 161, 145).

Overall, this rhetoric drew on a substantial body of progressive political thought about distributive questions. These were periods of frenetic but principled public intellectualism on the left: both left liberal and socialist ideologies furnished politicians with basic political insights that could then be rendered into more emotive and persuasive language suitable for a mass audience (I have discussed this theorising in Britain in Jackson 2007). The relationship between the populist rhetoric and the progressive political thought was complicated, and it can sometimes be hard to find precise affinities between the two enterprises (for a useful discussion of the methodological difficulties here see Bentley 1983: 137-43). Nonetheless, this intellectual productivity created an ideological environment from which politicians drew certain basic assumptions or generic conceptual forms, establishing a common sense that framed policy-making debates and gradually percolated into political speeches. Seen from a purely philosophical perspective, the political ideas used for rhetorical purposes were relatively unsophisticated and sometimes even crude, but they nonetheless bore some relationship to more conceptually complex ideologies. Roughly, the core insight that was absorbed from progressive political theory was that each individual required a certain share of material resources in order to attain certain widely valued political ideals: freedom, equal opportunity, security, social justice, democratic participation.

The classic example of this general claim was the widespread determination to wrest the rhetoric of liberty from the right by demonstrating that redistribution would in fact expand individual freedom. The obvious riposte from the opponents of progressive taxation and the welfare state was that such schemes would attack individual freedom by expropriating justly earned wealth; or by constraining the liberty of individuals to engage in commercial activity; or by greatly expanding the power of the state. 'What is this liberty that we have crucified? This liberty we have slain?' asked 
Democratic Senator Alben W. Barkley at the Democratic Party Convention in 1936:

Is it the freedom of workers to free collective bargaining? Is it the freedom of farmers to escape the loathsome peonage imposed on them by land and property speculators? Is it the freedom of investors to circumvent the secret devices of stock manipulators? Is it the freedom of bank depositors from the fear of loss of their savings? Is it the freedom of home owners and home lovers to protect and preserve their firesides?

The liberty that the New Deal opposed was only 'the liberty of small groups of people to pick the pockets of the American people' and 'the liberty of organised greed to pervert the agencies of the American government to their own enrichment'. The New Deal would in fact liberate individuals from 'economic serfdom' and 'wage slavery', added other speakers. Just as Lincoln opposed 'those who found monetary profit in holding fellow human beings in bondage, so against Roosevelt there are united those who find pecuniary gain in the industrial serfdom of women and children' (Barkley et al. all in PDNC: 47, 21, 227). The political language of the opponents of redistribution, it was argued, simply made a mockery of the meaning of freedom and individual rights: 'the right to live involves the right to have the means to sustain life' ( $\mathrm{P}$. McNutt in PDNC: 230). ${ }^{15}$ Progressives were not prepared to cede the value of liberty to the right, and nor were they willing to accept that the ideological contest between right and left should be caricatured as one that opposed 'liberty' to 'equality'.

The rhetoric of redistribution was therefore constructed by politicians from conceptual materials and ideological traditions that were left-liberal or social democratic or socialist in provenance. It was not rhetoric that sought to articulate populist sentiments disconnected from existing ideological alignments in order to transcend or triangulate between existing political languages and organisations. It was rhetoric imbued with the arguments, assumptions and strategies of the left and designed to confront the arguments, assumptions and strategies of the right.

\section{'We can do it'}

My discussion so far has described a rhetoric of economic populism and social patriotism, crafted to mobilise low- and middle-income citizens in a political coalition against the economic interests of the rich, a populism with a substantive political content drawn from left-liberal and socialist political thought. My final observation about the character of the rhetoric of redistribution concerns the deeper assumptions about political agency 
that it made, and that it sought to disseminate to a wider public in the course of political debate.

This political rhetoric communicated an important message about the limits of the individual's responsibility for their economic fate, both in a backward-looking and a forward-looking sense. In a backward-looking sense, as the emphasis on security also implied, poverty and unemployment were depicted as the consequences of social processes, of unpredictable market fluctuations that simply were not susceptible to individual control. This could lead to vivid oratory that linked this thought to the economic populism and the view of social justice discussed earlier. Lloyd George conjured up the case of 'a good workman' made unemployed:

whose fault is it? Perhaps some greedy financiers, it may be in some other country altogether, who, in their eagerness to get very rich, overstep the bounds of prudent speculation. There is a crash. A panic follows. The trade routes are blocked with the debris, and hundred of thousands, nay, millions of workmen in many lands are forced to remain idle until the roads are cleared and traffic is resumed ... Is it just, is it fair, is it humane to let them suffer privation? (1.10.1908, Swansea, BT: 54)

Similarly, it was argued that great individual wealth was the result of social cooperation, dependent upon the efforts of many individuals and social institutions, and not simply the heroic entrepreneurship of a Henry Ford or a William Morris. Roosevelt cited the words of Andrew Carnegie: 'Where wealth accrues honourably, the people are always silent partners' (19.6.1935, message to Congress on tax revision, FDR vol. 4: 272).

Just as there were limits to individual responsibility in this backwardlooking sense, there were also limits in a forward-looking sense: individuals could not solve these problems on their own. This highlighted the need for collective action to overcome the unfairness produced by market activity. As Beveridge argued: 'Poverty is a crime, and the only question is, who is the criminal? Not, I suggest, the poor man, but the society which permits needless poverty' (Beveridge 1944b: 8). The rhetoric of redistribution conveyed confidence, even a breezy optimism, about the capacity of collective action to solve social problems. The 'socialist principle', argued Herbert Morrison, was 'to do things collectively for the individual citizens . . . which individuals could not well do for themselves'. For example: 'the citizen cannot adequately protect himself and his family by his own unaided effort. He must combine. Alone he risks collapse; but he can, by co-operating and by creating a fund, protect his family and his dependants from poverty and want' (19.6.1947, London, PR: 38, 39). Of course, these ideas were not restricted to those who self-identified as socialists: left-liberal politicians expressed similar sentiments. Frances Perkins, Roosevelt's Secretary of Labour, sounded the same note in a 1935 radio broadcast as 
she introduced the nation to social security: it was one example, she said, of 'using co-operation through government to overcome social hazards against which the individual alone is inadequate' (2.9.1935, in Zinn 1966: 281).

Such rhetoric sought to redraw the accepted boundary between individual and collective responsibility, and to persuade voters that collective action through the state was a plausible and efficient means of addressing social harms. To this end, social problems were said to be analogous to other, more familiar crises, which had previously been addressed through collective action. Just as preventive or ameliorative measures were undertaken to counteract natural disasters, argued Roosevelt, 'the strong arm of the nation' was 'needed equally in taking measures to prevent economic disasters which are not natural, but are made by man' (25.4.1936, New York, FDR vol. 5: 178). Indeed, this point could be pushed further. As Beveridge noted, 'depressions of trade are not like earthquakes or cyclones; they are man-made', which suggested that a well-designed economic system might even be able to avert them altogether (Beveridge 1944a: 249). Roosevelt also claimed that curing social problems represented a challenge similar to earlier struggles against 'the ravages of diseases that years ago were regarded as unavoidable and inevitable' (24.8.1935, radio broadcast, FDR vol. 4: 341). This medical image also invoked the spirit of scientific progress. The implication was that social reform represented both a natural extension of scientific inquiry and the cutting edge of human ingenuity: reformers were engaged in 'social pioneering', said Roosevelt, likening them to the builders of the United States (13.4.1936, Baltimore, FDR vol. 5: 165; see too Plotke 1996: 171-4).

Why is this emphasis on collective agency significant? Communicating to the electorate the conviction that 'we can do it' is obviously critical when mobilising public support for ambitious measures of social reform. Conquering scepticism about the efficacy of political action should therefore be a key priority in any successful progressive rhetoric, and it is salutary to remember that radical politicians of the past had to face and conquer deep-seated doubts about state capacity. Although it is a familiar point, it is worth remembering in this context that present-day progressive rhetoric is characterised by almost precisely the opposite view: it emphasises the constraints on government action; the nation-state's inability to control and shape economic forces; and the failure of the state-led model of social reform. Just as present-day politicians on the left have turned away from contrasting social patriotism with the sectional interests of the wealthy, and just as the same politicians have lost a public lexicon shaped by leftliberal or socialist political thought, today's progressive politicians express 
fatalism about the prospects for collective action and doubt about the state's role as an agent of the common good.

\section{Conclusion}

This chapter has tried to dislodge some entrenched assumptions about the political rhetoric used in the past to mobilise support for economic redistribution. Far from preaching a leftist fundamentalism explicitly targeted at the working class, leading radical politicians in fact employed a more moderate discourse of the public interest that appealed to national rather than class identity. They mobilised popular support by introducing a negative characterisation of the social contribution made by the wealthy and depicting low- and middle-income voters as allies in the national cause. The political content of this social patriotism was determined by the appropriation of important and prestigious values. A fair and democratic society, it was argued, should ensure security and opportunity for all; adequately reward the contribution made by the low-paid; and restrict the economic and political power wielded by the wealthiest. More general points about collective responsibility and the power of the democratic state were also articulated to inspire confidence in the efficacy of redistributive solutions. As I indicated at the outset, my task here has been primarily interpretive. Although I do think that it would be feasible to employ these rhetorical strategies in contemporary political controversies, I have not sought to make this case in this chapter. However, the evidence assembled here does suggest that, before any further electoral strategies are presented as improving upon a caricatured ancestral leftist fundamentalism, political strategists should at least acknowledge the authentic character of the rhetoric of redistribution. ${ }^{16}$

\section{Notes}

1 An earlier version of this chapter was presented at the third Rethinking Social Democracy Conference held at Sheffield University in June 2006 and at several other conferences and seminars. I am grateful to all those who commented on it in its earlier guise. Particular thanks are due to Gregg McClymont, Martin McIvor and Zofia Stemplowska for reading and commenting on the penultimate draft.

2 My quotes from these speeches and broadcasts will adopt the following conventions. For my chief sources, I will indicate in brackets after each quote the date and place of the speech (or identify it as a radio broadcast), along with one of the following abbreviations to identify its location in print:

BT Lloyd George, D. (1910) Better Times: Speeches by D. Lloyd George

FDR Roosevelt, F. D. (1938-50) The Public Papers and Addresses of Franklin D. Roosevelt

PDNC Democratic Party (1936) The Proceedings of the Democratic National 
Convention 1936

PR Morrison, H. (1949) The Peaceful Revolution: Speeches by the Rt. Hon. Herbert Morrison

PP Attlee, C. R. (1946) Purpose and Policy: Selected Speeches

PS Beveridge, W. (1943) The Pillars of Security and Other War-time Essays and Addresses

References to parliamentary speeches will be given in the end-notes.

3 One study in this vein has greatly influenced my approach: Albert Hirschman's The Rhetoric of Reaction (1991), from which I have also adapted the title of this chapter.

4 For contemporary emphasis on this point, see Graetz and Shapiro 2005: 226-35; Fabian Society 2005: 16-34.

5 My understanding of the technique of 'rhetorical redescription' is derived from Skinner 1996: 138-80; Skinner 2002: 182-6.

6 Dalton was quoting H. G. Wells: H. Dalton, 9.4.1946, Parl. Deb., 5th Ser., vol. 421 , col. 1835.

7 See also the similar point made by the Labour MP James O'Grady in support of the introduction of old-age pensions, 15.6.1908, Parl. Deb., 4th Ser., vol. 190, col. 621 .

8 See also the recurring criticism of the greed and selfishness of the rich in PDNC, e.g. 21-3, 47-8, 212-13, 269. For the appropriation of this rhetorical style and the epithet 'economic royalists' by US trade unionists, see Gerstle 1989: 169-74.

9 Here I depart from Aristotle, who sees ethos as a matter of speakers projecting a positive image of their character solely through their rhetoric, not because of any powerful political offices they happen to hold or any other prior assumptions about the kind of person they are (Aristotle 1984, Bk 1, Ch. 2: 2155). But in the case I am investigating here, it seems to me significant to understanding the persuasive force of redistributive rhetoric that powerful politicians placed the authority of their offices behind it.

10 W. S. Churchill, 3.5.1909, Parl. Deb., 5th Ser., vol. 4, col. 854.

11 For the background to the 'Americanism' of the New Dealers, see Gerstle 1989, especially 8-9, 156-8, 166-95, 216-49.

12 L. Chiozza Money, 17.5.1909, Parl. Deb., 5th Ser., vol. 5, col. 46.

13 This was one reason for Lloyd George's focus on the landed aristocracy rather than other wealthy groups, as a means of exploiting middle-class resentment against the aristocracy: see Grigg 1997: 213.

14 For example, in Roosevelt's invocation of the 'four freedoms': freedom of speech, of worship, from want and from fear (6.1.1941, message to congress, FDR vol. 9; 7.1.1943, state of union address, FDR vol. 12: 30-4).

15 See also the same point made by Labour MP James Griffiths in the parliamentary debate on the Beveridge Report, 18.2.1943, Parl. Deb., 5th Ser., vol. 386, col. 1966.

16 Indeed, it should be acknowledged that in the USA Democratic politicians and strategists have very recently shown signs of gravitating towards an 'economic 
populism' which goes some way towards meeting the concerns of this chapter: see e.g. Toner 2007.

\section{References}

Addison, P. (1975) The Road to 1945 (London: Cape).

Anderson, L. (1990) Making a New Deal: Industrial Workers in Chicago 1919-39 (Cambridge: Cambridge University Press).

Aristotle (1984) Rhetoric, in The Complete Works of Aristotle, ed. J. Barnes (Princeton: Princeton University Press).

Attlee, C. R. (1946) Purpose and Policy: Selected Speeches (London: Hutchinson \& Co.).

Bentley, M. (1983) 'Party, doctrine and thought', in M. Bentley and J. Stevenson (eds), High and Low Politics in Modern Britain (Oxford: Oxford University Press).

Beveridge, W. (1943) The Pillars of Security and Other War-time Essays and Addresses (London: Allen \& Unwin).

Beveridge, W. (1944a) Full Employment in a Free Society (London: Allen \& Unwin).

Beveridge, W. (1944b) Security and Adventure (London: Council for Education in World Citizenship).

Brewer, M., Goodman, A., Muriel, A., Phillips, D. and Sibieta, L. (2008) Poverty and Inequality in the UK: 2008 (London: Institute for Fiscal Studies).

Clarke, P. (1974) 'Introduction' to J. A. Hobson, The Crisis of Liberalism (Brighton: Harvester).

Cripps, S. (1946) Democracy Alive: a Selection from Recent Speeches by the Rt. Hon. Sir Stafford Cripps (London: Sidgwick \& Jackson).

Cronin, J. (1984) Labour and Society in Britain 1918-79 (London: Batsford).

Economist, The (2005) 'The flat tax revolution', 14 April.

Democratic Party (1936) The Proceedings of the Democratic National Convention 1936 (Washington, DC).

Fabian Society (2005) Why Life Chances Matter (London: Fabian Society).

Freeden, M. (1996) Ideologies and Political Theory (Oxford: Oxford University Press).

Freeden, M. (2003) 'The coming of the welfare state', in T. Ball and R. Bellamy (eds), The Cambridge History of Twentieth Century Political Thought (Cambridge: Cambridge University Press).

Gerstle, G. (1989) Working Class Americanism: the Politics of Labor in a Textile City (Cambridge: Cambridge University Press).

Graetz, M. J. and Shapiro, I. (2005) Death by a Thousand Cuts (Princeton: Princeton University Press).

Grigg, J. ([1978] 1997) Lloyd George: the People's Champion 1902-1911 (London: Penguin).

Hirschman, A. (1991) The Rhetoric of Reaction (Cambridge, MA: Harvard University Press).

Jackson, B. (2007) Equality and the British Left: a Study in Progressive Political Thought 1900-64 (Manchester: Manchester University Press). 
Lloyd George, D. (1910) Better Times: Speeches by D. Lloyd George (London: Hodder \& Stoughton).

Matthew, H. C. G. (1995) Gladstone Volume 2: 1875-1898 (Oxford: Oxford University Press).

Morrison, H. (1949) The Peaceful Revolution: Speeches by the Rt. Hon. Herbert Morrison (London: Allen \& Unwin).

Plotke, D. (1996) Building a Democratic Political Order: Reshaping American Liberalism in the 1930s and 1940s (Cambridge: Cambridge University Press).

Roosevelt, F. D. (1938-50) The Public Papers and Addresses of Franklin D. Roosevelt (New York: Russell \& Russell).

Skinner, Q. (1996) Reason and Rhetoric in the Philosophy of Hobbes (Cambridge: Cambridge University Press).

Skinner, Q. (2002) Visions of Politics Volume 1: on Method (Cambridge: Cambridge University Press).

Stears, M. (2005) 'The vocation of political theory: principles, empirical inquiry and the politics of opportunity', European Journal of Political Theory, 4.

Thane, P. (1984) 'The working class and state "welfare" in Britain, 1880-1914', Historical Journal, 27.

Toner, R. (2007) 'A new populism spurs Democrats on the economy', New York Times, 16 July.

White, S. (2003) The Civic Minimum (Oxford: Oxford University Press).

Zinn, H. (ed.) (1966) New Deal Thought (Indianapolis: Bobbs-Merrill Co.). 


\title{
Republicanism, socialism and the renewal of the left ${ }^{1}$
}

\author{
Martin McIvor
}

Recent soul-searching among the intellectual left has returned with increasing frequency and interest to implicitly or explicitly 'republican' themes and arguments. As class identities fracture, and state ownership falls into disrepute, republican conceptions of equal citizenship and the inherent value of a 'public realm' have appealed to many as potentially productive starting points for the left's ideological renewal.

This is not an especially new idea. As early as 1991, an important historical review of the Labour Party's roots in democratic movements of the nineteenth century suggested that 'the Labour Party's ability to play a leading role in broad progressive movements in the future will be strengthened if it becomes more restrained in its tendency to legitimise its policies primarily in relation to "socialism", and if it develops more self-consciousness of, and more pride in, its relation to currents of radicalism' (Biagini and Reid 1991: 19). But it has reappeared with increasing frequency of late. Gareth Stedman Jones has suggested that 'contemporary social democracy' should 'revisit its birthplace' of the late eighteenth century, when pioneering thinkers such as Paine and Condorcet sought to update 'a republican ideal of greater equality, inclusive citizenship and the public good' for modern times (Stedman Jones 2004: 245). Stuart White has asked if republicanism might now be 'the left's "big idea", and while concluding that its legacy is too complex to be reduced to a single, all-encompassing idea, is in no doubt that 'the idea of grounding social democracy in a republican conception of citizenship and the state is one we urgently need to rehabilitate' (White 2007: 44). David Marquand has argued that after the failure of its 'essentially paternalist model of social-democracy', 'what Labour now needs to do is revisit what I think of as the "democratic republican" strand in its heritage - the strand that goes back to Milton's thunderous prose and Tom Paine's magnificent audacity: the strand that emphasises self government by free and active citizens in a polity they own' (Marquand 2008). 
Broadly speaking, two key factors seem to lie behind this trend. One is the extraordinary wave of scholarly work, building since the 1970s and now a veritable academic 'industry', that has sought to recover a republican intellectual heritage and develop it for contemporary purposes. Historians inspired by the pioneering work of Quentin Skinner and J. G. A. Pocock have brought to light a tradition of political thought that had hitherto been somewhat hidden from view, a tradition of civic republican ideas that, drawing on classical sources, was revived at the time of the Renaissance and went on to influence the English radicalism of the seventeenth century, the American and French revolutions of the eighteenth century, and the great nationalist and democratic movements of the nineteenth century. Innovative political theorists such as Philip Pettit have drawn on this work to propose the continuing relevance and value of republican ideas and arguments as offering a powerful theoretical alternative to both 'liberal' and 'communitarian' political philosophies. ${ }^{2}$

Second, the specific contours of the contemporary 'conjuncture' mean that these ideas have proved particularly attractive to a left that is struggling to redefine its project after the collapse of state socialism and the declining appeal of a top-down, bureaucratic corporatism and welfarism, and to respond to widespread concerns about the deteriorating social fabric and 'hollowed-out' politics of the contemporary market societies that neo-liberalism is creating. Republican ideas seem to promise a route back to the values of freedom and democracy that the twentieth-century left seemed too often to lose touch with, at the same time as offering a viable and sophisticated defence of political activism and social commitment that could prove newly resonant for contemporary audiences. Nor has this been a purely academic or intellectual phenomenon - the renewed currency of republican values and concepts has begun to infuse contemporary policy debates around constitutional reform, the importance of 'civil society', and extending, as we shall see, to suggest new rationales for reforms aimed at securing greater social and economic equality. As Chapter 5 in this volume shows, the possibility that a reconstructed republicanism might offer a viable governing philosophy for twenty-first century social democracy has been taken up with particular enthusiasm by the Spanish Socialists, who went so far as to invite Philip Pettit to assess their performance against his own republican principles.

In this chapter, I want to welcome and endorse this republican revival, but also to sound a note of qualification or caution. It seems to me that the left today can find much nourishment in a recovery of its republican inheritance. But I want also to suggest reasons for thinking that there may be something inherently unstable about this set of ideas, that they have proved increasingly inadequate to the realities of modern societies 
and modern economies, and that in this sense the left's shift of focus from republican concerns to socialist and social democratic ambitions in the later nineteenth and earlier twentieth centuries was to some degree well motivated. This is not to argue that we can simply revert to the old values and forms of 'industrial' collectivism - for there is no doubt that they too came undone in a losing confrontation with social and economic change in the later twentieth century. But it is to argue that the difficult relationship between republican objectives and more ambitious and challenging forms of collectivism is one that the left must continue to grapple with.

A major caveat must be entered at this point: in surveying and critiquing historical and contemporary arguments around the relationship between republican and socialist ideas, this article can be only a sketch, and a necessarily crude one, unable to do justice to the historical complexities and philosophical nuances buried within this literature. My hope is that by taking such a broad view, at the expense of subtlety or detail, overarching continuities and recurrent issues come into view. But that will of course be for the reader to judge.

\section{Liberty as self-government}

The central starting point for the most influential reconstructions of the republican paradigm is the critique of arbitrary power, to which is opposed a particular ideal of freedom. According to Quentin Skinner, this idea can be traced back to the basic distinction in Roman law between a free man and a slave, and is picked up and redeveloped as a key political idea in Europe in the early modern period (Skinner 1997). According to Philip Pettit, this notion of 'freedom as non-domination' offers a compelling alternative to the more familiar liberal idea of 'negative' freedom as 'non-interference' (Pettit 1999). Even if my freedom of action is not directly interfered with, I may be 'unfree' in republican terms if I remain at the mercy of another who might at any point choose to restrain me - just as a slave is no less a slave if his or her master is generous or benign. Domination is thus a predicament of dependence upon the will of another, while true liberty consists in self-government - a condition in which I can be judged the true author of my actions, because they issue directly from my own agency without reference to the approval or otherwise of another. This notion lay at the heart of early critiques of absolute monarchies as a form of domination or despotism, irrespective of the character and behaviour of the monarch. It was not because they always did interfere with our freedom, but because they always could, that such arrangements rendered us slaves. As Paine put it in his seminal defence of the French Revolution: 'It was not against Louis XVI but against the despotic principle of the government that the nation 
revolted ... All the tyrannies of former reigns, acted under that hereditary despotism, were still liable to be revived in the hands of a successor' (Paine 1998: 98). It is because of this that we must take an active interest in our governing arrangements, and play our full part as virtuous citizens - as the only reliable means of securing ourselves against arbitrary interference.

There is however a further important development of this thought, one which is arguably pivotal to republican political thinking but which often, I think, is symptomatically underexamined or underdeveloped in many contemporary accounts. It is important for what I will go on to say, so it is worth flagging up at this point. This is the thought that, in so far as individuals are inextricably interdependent as a result of their social natures (or, if you prefer, historically acquired needs and characteristics), liberty as self-government can only be attained collectively, through universal submission to a form of rule that can be accepted by all advancing a common good. This latter stipulation of course creates a whole host of possibilities and problems, but is, I think, the only way we can give force to the critique of arbitrary power that is the republican starting point - power that is not just unpredictable, but somehow irrational or without justification. My claim, then, is that an essential dimension of republican political thought is the difficult but necessary task of developing a theory of collective agency that is consistent with individual self-rule. Thus for Spinoza some form of political association was an inescapable consequence of our need for mutual protection and our desire for friendship or amicitia - an 'affective' interdependence that we cannot break but which, by means of our rational powers, we can at least comprehend and so master. In 1670 he wrote that 'in a state or kingdom where the weal of the whole people, and not that of the ruler, is the supreme law, obedience to the sovereign power does not make man a slave ... that state is the freest whose laws are founded on sound reason, so that every member of it may, if he will, be free, that is live with full consent under the entire guidance of reason' (Spinoza 2005: 206). And in the most famous version of this argument Rousseau, who proposed that our 'chains' of interdependence could be rendered 'legitimate', and so our natural freedom regained in a moral or socialised form, if we could 'find a form of association that will defend and protect the person and goods of each associate with the full common force, and by means of which each, uniting with all, nevertheless obeys only himself and remains as free as before' (Rousseau 1997: 49-50). This form of association was the social contract, under which each promises unconditional obedience to a general will which seeks only the interests of the whole.

This transition - from freedom as individual self-government to freedom as submission to a rationally or democratically determined collective interest-remains a startling and, to many, troubling step in the republican 
argument. Rousseau's contested status as an authentic representative of the republican tradition is an illustrative moot point - Pettit, for example, seems to want to draw a line here. ${ }^{3}$ There is no doubt that the idea of identifying a 'collective interest' in a democratic or rational way, such that one who submits to its rule may be said to be obeying only themselves, poses a daunting set of philosophical and practical problems, and it is immediately obvious how such a proposal must be perilously vulnerable to misappropriation or abuse. But the point seen clearly by Spinoza and Rousseau, and too often evaded in contemporary appropriations of republican ideas, is that to the extent that we are dependent upon one another and cannot simply withdraw to our private, self-regarding spheres, this challenge is simply inescapable. The republican project is then not simply one of restraining the governing power to preserve our individual liberty, but also of pooling our liberty so that we might act together in pursuit of shared interests. One way of putting this point might be to assert that, to the extent that our fates are intertwined, the 'common good' to which our collective power is directed must be substantive and specific - not merely the formal principle of individual freedom from interference, but actual shared projects. ${ }^{4}$

\section{The passage from republicanism to socialism}

During the nineteenth century, republican political ideas about the forms of law and government were gradually displaced on the European left by a concern with economic relationships and ultimately a commitment to some notion of collective ownership of the means of production. Although most left movements and parties retained their commitment to democratic reforms, this was increasingly seen as an instrumental and relatively superficial precursor to more fundamental economic change. Sometimes this seems to express a degree of disillusionment and cynicism about the importance and value of 'politics' as such, in the name of a utilitarian concern with material living standards, a romantic commitment to a more profound social harmony, or an orthodox Marxist identification of the economic base as ultimately determinant (Bevir 2000). There is no doubt that these intellectual currents were influential, and that they diverted the left's agenda in ways that today seem unfortunate, perhaps fateful. Too many on the left seemed to have made the complacent assumption that the achievement of liberal, constitutional democracies allowed them to focus on other issues - meaning that the institutions they went on to build were undermined by the legitimate revolts of those in society - notably women and minorities - who were still far from receiving equal treatment and representation. ${ }^{5}$ But I want to suggest that there is another story to tell: about how socialist and social democratic ideas developed more logically 
and continuously from earlier republican agendas, the concerns of which they internalised and relocated. Briefly stated, it can be argued that as industrialisation and expanding trade extended and intensified the reality of interdependence, a consistent commitment to freedom from domination through collective self-government logically entailed attempts to bring the economy under collective democratic control.

Behind this story lies the traditional association of republican political ideas with predominantly agrarian economies that favoured relatively small-scale units of production and a significant degree of self-sufficiency. Although the preferred economic models of republican thinkers varied enormously - from Harrington's commonwealth of landowners to Rousseau's idealised peasant communities - a common theme was the notion that each owned enough to prevent dependence upon any other, but never so much more than others as to render others dependent. This restriction on material inequality secured for everyone the independence to act as a free citizen and guarded the republic against corruption or tyranny (White 2001).

But of course the growth of commercial trade and productive industry through the eighteenth and nineteenth centuries undermined the purchase, plausibility and appeal of this image of upright independence. The reality of modern economies has for the most part been an extension and intensification of interdependence - most individuals spend a measurably diminishing portion of their time acting or working for themselves in an unmediated way, and an increasingly predominant part of their time working to meet the needs of increasing numbers of others - either in response to market signals or under the command of an employer through whom the needs of the market are transmitted. And at the same time most individuals increasingly rely on the productive activities of increasing numbers of other individuals to meet their own developing needs. Some early writers warned against these developments - the American founding fathers worried about trends favouring inequality and the pursuit of luxury, and republican thinkers such as Price and Jefferson warned against the influence of commercial and manufacturing imperatives. Others, like Adam Smith, who celebrated this advancing division of labour, hoped that the rise of a commercially minded middle class might be reconciled with the preservation of civic virtues (Winch 2002). Indeed, for Smith the very spread of commerce served to unravel the ties of feudal power and servitude: "nothing tends so much to corrupt and enervate and debase the mind as dependency, and nothing gives such noble and generous notions of probity as freedom and independence. Commerce is one great preventative of this custom' (quoted by McNally 1993: 53).

But as David McNally has argued, Smith's 'model of commercial society 
based upon interaction between independent commodity producers like butchers, brewers and bakers' is in tension with the reality of modern Europe, in which as he acknowledges, 'the greater part of the workmen stand in need of a master' and wage-labourers outnumber independent workmen by a ratio of 20 to 1 (McNally 1993: 53-5). As Geoff Eley puts it, 'artisans increasingly lost control of their trades to the impersonal forces of the capitalist market. They surrendered the autonomy of the workshop to the practical forms of dependence on larger-scale business organization, before eventually becoming integrated directly into superordinate structures of capitalist production, employment, and control' (Eley 2002: 19-20). A recurrent argument of early socialists was that this economic dependence constituted a form of domination no less significant than the political domination of an unelected or unaccountable ruler - indeed perhaps even more existentially pervasive, on account of the very importance accorded to questions of property and labour by early republican thinkers.

Thus in E. P. Thompson's account the early years of Owenism and Chartism:

reveal a passing beyond the characteristic outlook of the artisan, with his desire for an independent livelihood 'by the sweat of his brow', to a newer outlook, more reconciled to the new means of production, but seeking to exert the collective power of the class to humanize the environment - by this community or that cooperative society, by this check on the blind operation of the market-economy, by this legal enactment, that measure of relief of the poor. (Thompson 1962: 910-13)

Gareth Stedman Jones has rightly warned against teleological readings of nineteenth century radicalism as the inessential or superficial expression of a deeper class antagonism (Stedman Jones 1983). But the writings of the Chartist period reveal an acute awareness of the developing interrelation of legal domination and economic exploitation, and of capitalism -in the form it was then taking - as a profoundly political construction. And the corresponding interconnection of republican self-governance and collective economic regulation was pursued and developed through William James Linton's English Republic and the early formation of the Social Democratic Federation.

Similar continuities can be seen in the development of socialism in France. In the 1840s Pierre-Joseph Proudhon, an ardent (if idiosyncratic) follower of Rousseau, justified his denunciation of property as a refusal of arbitrary power, in both political and economic forms. "The proprietor, the robber, the hero, and the sovereign (for all these titles are synonymous) each imposes his will as law and suffers neither contradiction nor control ... property necessarily engenders despotism, the government of arbitrary 
will, the reign of libidinous pleasure'. For Proudhon, government was a matter of 'public economy' - 'its object is production and consumption, the distribution of labour and products' - but this objective of economic regulation was obstructed and undermined by the existence of private proprietors - 'despotic kings ... in proportion to their acquisitive faculties' (Proudhon 1994: 210). Proudhon's translation of republican into socialist principle is bold and explicit: 'since property is the great cause of privilege and despotism, the form of the republican oath should be changed. Instead of saying, "I swear hatred to royalty", an applicant to a secret society should henceforth say, "I swear hatred to property"' (Proudhon 1994: 158-9). Even the later incursion of Marxist thought into French socialism did not prevent what Tony Judt describes as 'a long period of overlap during which the socialism of Jaurès and Blum combined Marxist social analysis and final goals with democratic or republican methods drawn from the earlier tradition' (Judt 1986: 7).

And in fact the direct transposition of republican concerns into the domain of the economy is right at the heart of Marx's thinking, though this was all but invisible in the orthodox versions of Marxism that dominated the Second International in the latter years of the nineteenth century. Marx's early thinking was much exercised by Prussia's social and political backwardness, and in particular the persistence of neo-feudal relations of personal lordship and dependence (Herrschaft) ${ }^{6}$ But his thought develops as a critical interrogation of the notion that the market liberates individuals from feudal ties, arguing that the formal independence of the labourer as free seller of his own labour-power is subverted by the background conditions that leave him little choice but to submit again and again to his own exploitation. 'In the developed system of exchange (and this semblance seduces the democrats), the ties of personal dependence, of distinctions of blood, education, etc, are in fact exploded, ripped up . . . and individuals seem independent', Marx writes in the Grundrisse of 1858, as if in direct rejoinder to Smith. 'But they appear thus only for someone who abstracts from ... the conditions of existence within which these individuals enter into contact ... The abstraction, or idea, however, is nothing more than the theoretical expression of those material relations which are their lord and master' (Marx 1973: 163-4). For Marx, then, the fact that we are dominated by an impersonal force, 'the market', or 'the economy' or 'capital', makes it no less arbitrary a tyranny. Marx's occasional invocations of the abstract communist ideal suggest a utopian yet luminous redrawing of Rousseau's social contract to take in the full range and depth of our economic interactions: 'an association of free men, working with the means of production held in common, and expending their many different forms of labour-power in full self-awareness as one single social labour force' (Marx 
1990: 171). And his accounts of the more concrete if partial advances of the working-class movement present them unambiguously as early steps towards collective economic self-government: as they win the battle for legislation to regulate the conditions of their labour, the working class 'transform that [governmental] power, now used against them, into their own agency. They effect by a general act what they would vainly attempt by a multitude of individual efforts' (Marx 1974: 89).

The Chartists, Proudhon and Marx are offered here only as brief illustrations of an uneven but unmistakeable trend that can be followed through the nineteenth-century left - as Eley puts it, a delinking of "calls for democracy' from 'ideals of small-scale organization, local community, and personal independence' that were becoming 'far harder to sustain':

That is, under conditions of capitalist industrialisation the implications of demanding popular sovereignty became profoundly transformed. Gradually and unevenly, democracy became linked to two new demands: an economic analysis of capitalism and a political program for the general reorganizing of society . . It was in that moment of transformation that people began exploring the possibilities of collective ownership and socialism. (Eley 2002: $18-20)$

\section{The political economy of contemporary neo-republicanism}

The history of the twentieth century is to some extent the history of the ultimate failure or defeat of those attempts to 'make democracy social' as Eley puts it. The full-blown version of collective economic control through centralised planning certainly proved unable to either meet people's developing material needs or meaningfully actualise the impulse to economic self-government that lay behind its initial formulation. More partial 'social democratic' variants, which left significant domains of market relations and private ownership in place but sought to correct their tendency to centralise social and economic power through measures of partial decommodification, corporate representation and selective socialisation, also stand accused of depressing economic dynamism and impeding genuine empowerment.

It is against this background that the left has retreated from economic collectivism and sought to anchor its objectives more firmly on the ground of individual autonomy and democratic participation. This, of course, is where classical republican arguments come into their own. But this still raises the question of whether contemporary capitalism furnishes the social and economic conditions for individual and collective self-government - or whether the new republican revival entails its own, distinctive agenda for economic and social reform. In so far as contemporary discussions have 
pursued such questions, they have tended to converge on a cluster of ideas and proposals that I think can reasonably be brought under the heading of a 'property-owning democracy'.

The common impulse behind these schemes is the thought that appropriately designed mechanisms of redistribution and regulation can perform a task similar to the classical republicans' 'agrarian law' for modern commercial economies - ensure that every citizen has enough private property to secure their independence, yet never so much that they might be capable of dominating others. As Gareth Stedman Jones has shown, we can trace early versions of this programme to the proposals of Thomas Paine and Antoine-Nicolas Condorcet for systems of universal social insurance that could provide every member of society with the security and independence they needed to develop the capacity and the virtues of active citizenship (Stedman Jones 2004). More recently the idea has been given a new outing by John Rawls, who, despite his customary classification as the most influential liberal thinker of the late twentieth century, in fact claimed in his later writings to be closer to the republican tradition (Rawls 2001). Drawing on the work of the post-war social democratic economist James Meade, Rawls goes on to argue that the most appropriate economic arrangements for the realisation of his political ideal is not, as is commonly assumed, a form of 'welfare-state capitalism', but a 'property-owning democracy' in which 'background institutions ... work to disperse the ownership of wealth and capital, and thus to prevent a small part of society from controlling the economy, and indirectly, political life as well'. By ensuring 'the widespread ownership of productive assets and human capital' such an economy might 'put all citizens in a position to manage their own affairs on a footing of a suitable degree of social and economic equality' (Rawls 2001: 139, quoted in Dagger 2006: 160-1).

This need not be so abstract as the Rawlsian style of philosophy might lead us to assume. Indeed, it can be seen to dovetail very closely with contemporary policy innovations aimed precisely at advancing the left's ideals of equal autonomy and participation in a way that escapes the impasse of twentieth-century social democracy. Stuart White in particular has developed a fascinating line of work that links the political aspirations of republicanism and the 'property-owning democracy' with the real-world experiments in 'citizens' income', 'asset-based welfare' and 'stakeholderism' being developed by centre-left governments around the world today (White 2001, 2003; see also Raventós 2007; Paxton 2003; Ackerman and Alstott 1999). The broad argument is that even if we must give up the attempt to exercise economic self-governance by submitting our productive activities to collective regulation and control, we can combine the efficiency and dynamism of markets with the social and economic equality 
necessary to underpin a genuinely republican politics by redistributing concentrations of private wealth (through inheritance tax, for example) to ensure that no individual ever becomes completely dependent on a particular form of employment and that all have the means to participate in the economic, social and political life of a society on broadly equal terms. To put the argument in simple, concrete terms: if we all knew we had a modest independent income and/or financial nest egg to fall back on, we would feel more emboldened to walk out of a demeaning or restrictive job, to take time out for educating ourselves, to start our own business, to engage in community activism, to pursue our artistic leanings, to publish our own newspaper (or, more likely today, maintain our own online 'blog'); as well as being able to exercise some democratic rights, or a degree of direct control, over the future economic development of my society by virtue of being a shareholder or investor.

These are exciting ideas and it is easy to see how they might form the basis for a revitalised and repopularised left project. But I think it is also appropriate that we ask hard questions about how far they can go, and what problems still remain with respect to the economic conditions for universal self-government. In particular, the history of the left in the nineteenth century should at least give us pause to consider whether the developing characteristics of modern economies upon which older republican programmes foundered might still pose a challenge for any attempt to recreate a 'property-owning democracy' for the twenty-first century.

The nub of the issue is, I think, whether the depth and extent of our economic interdependence, and the degree of socialisation of productive processes this entails, must render any attempt to secure a meaningful 'independence' through individual private property entitlements at risk of inadequacy and marginalisation. Practically speaking, there are surely grounds to doubt that the decentralisation of property entitlements can be matched by an equal decentralisation of productive processes - so that selfemployment or small-scale producer cooperatives become the norm. If that is granted, then the reality for many citizens will be that their 'property' consists of a 'stake' in larger productive enterprises - a situation similar to the position of today's employees of John Lewis, for example, or even that of the large portion of the workforce with an occupational or personal pension invested (usually through some intermediary) in contemporary stock markets. There is no question that the democratising potential of such incipient stakeholderism can and should be pushed much, much further (see Davis et al., 2006). But the challenge this presents is, I suggest, not actually so different from that faced by earlier forms of economic collectivism. This is the challenge of pooling our productive resources and capacities in forms of cooperative and socialised production that are sufficiently 
sophisticated to meet our diverse needs, and at the same time accommodate our aspirations for forms of work that can be experienced as genuine forms of self-expression and self-rule, rather than alienating or oppressive impositions. This is the task that history has set us. It is perhaps a far more difficult task than most early socialists imagined. But I don't think it is one that republicanism allows us to bypass or defer.

\section{Conclusion}

The danger of the 'property-owning' ideal, then, is that its signature ideal of individual independence may seem to offer a false escape alley from the dangers and difficulties of building forms of collective action and democratic self-rule that do not become distant, remote, unrepresentative and unresponsive. This is by no means to dismiss the value of the reforms that have been proposed under this banner, but rather to suggest that they might be seen as reinforcing accompaniments, rather than radical alternatives, to more direct efforts at collective control over our economic life such as trade union representation and industrial democracy (discussed in this volume in Chapter 14), government regulation and intervention, and, indeed, public ownership and planning.

But I want to end by making a point of disowning what I fear may be an unfortunate impression given by my argument - that of a progressivist teleology that holds up economic collectivism as a higher ideological or social form than republicanism. Republicanism is back on the agenda precisely because the economic collectivisms that succeeded it failed, or decayed. And here I want to add an additional argument for the contemporary value of the republican tradition. The progressivism of the Enlightenment and the philosophies of history that it spawned are often traduced and I think too glibly dismissed. But it is undoubtedly the case that they imbued social and political thinkers, on the left in particular, with sometimes unhelpful habits of thought. Here we can indeed return to the abiding concern of classical republicanism with the instability of any institutional or cultural achievement and the cyclical tendency for republics to rise and fall. The collective institutions of the twentieth century did lose their life, became captured by factions and detached from the lives of those they meant to serve. The sense of loss this engendered has been disorientating and disabling for the left, which had over decades become used to the idea that history was on its side. But an instructive leaf can be taken from the book of republican writers who knew all too well the propensity of their institutions to decline and die, and regarded their political mission as one of inculcating the virtues and the practices that could renew and sustain new forms of collective action. 


\section{Notes}

1 Numerous people have helped me develop the arguments laid out here, but I wish to extend particular thanks to Ben Jackson, Nina Fishman and John Callaghan for invaluable advice and encouragement on earlier drafts, and to Stuart White, whose work on these issues has been a central source and stimulus for my own thinking.

2 The relevant literature here is voluminous but a representative and up-to-date sample can be found in Laborde and Maynor 2008.

3 Pettit writes that 'while it is true that republican thinkers in general regarded democratic participation or representation as a safeguard of liberty, not as its defining core, the growing emphasis on democracy did lead some individuals away from traditional alignments and towards the full populist position of holding that liberty consists in nothing more or less than democratic self-rule. However republican and attractive his views in other respects, Rousseau is probably responsible for having given currency to such a populist view' (Pettit 1999: 30).

4 It may be that we forget how much the person and institution of the monarch once symbolised and embodied this more substantive sense of shared identity and common enterprise, because our remaining monarchs today exercise such a marginal and formal role. I am grateful to Nina Fishman for suggesting this point.

5 I am grateful to John Callaghan for suggesting this point to me.

6 See Breckman 1999. On the pivotal importance of this concept for Prussian conservative thought, see Berdahl 1988.

\section{References}

Ackerman, B. and Alstott, A. (1999) The Stakeholder Society (New Haven: Yale University Press).

Berdahl, R. M. (1988) The Politics of the Prussian Nobility: the Development of a Conservative Ideology 1770-1848 (Princeton: Princeton University Press).

Bevir, M. (2000) 'Republicanism, socialism, and democracy in Britain: the origins of the radical left', Journal of Social History, 34 (2).

Biagini, E. F. and Reid, A. J. (1991) 'Currents of radicalism, 1850-1914', in Biagini and Reid (eds), Currents of Radicalism: Popular Radicalism, Organised Labour and Party Politics in Britain, 1850-1914 (Cambridge: Cambridge University Press).

Breckman, W. (1999) Marx, the Young Hegelians, and the Origins of Radical Social Theory: Dethroning the Self (Cambridge: Cambridge University Press).

Dagger, R. (2006) 'Neo-republicanism and the civic economy', Politics, Philosophy and Economics, 5 (2).

Davis, S., Lukomnik, J. and Pitt-Watson, D. (2006) The New Capitalists: How Citizens are Reshaping the Corporate Agenda (Cambridge, MA: Harvard Business School Press). 
Eley, G. (2002) Forging Democracy: the History of the Left in Europe, 1850-2000 (Oxford: Oxford University Press).

Judt, T. (1986) Marxism and the French Left: Studies on Labour and Politics in France 1830-1981 (Oxford: Clarendon Press).

Laborde, C. and Maynor, J. (2008) Republicanism and Political Theory (Oxford: Wiley-Blackwell).

McNally, D. (1993) Against the Market: Political Economy, Market Socialism and the Marxist Critique (London: Verso).

Marquand, D. (2008) ‘England and Europe: two ‘Es that lie in wait for Brown's Britishness', published on Open Democracy News Analysis: www.opendemocracy.net, 1 February.

Marx, K. (1973) Grundrisse, trans. M. Nicolaus (London: Penguin Books).

Marx, K. (1974) 'Documents of the First International: 1864-70', in The First International and After: Political Writings: Volume 3, ed. D. Fernbach (London: Penguin Books).

Marx, K. (1990) Capital: Volume I, trans. B. Fowkes (London: Penguin Books).

O'Neill, M. (2008) 'Liberty, equality and property-owning democracy', Manchester Papers in Political Economy: www.socialsciences.manchester.ac.uk/cspe/publications/wp/documents/ONeillWP02-08.pdf (accessed 15 July 2008).

Paine, T. (1998) Rights of Man, Common Sense and other Political Writings, ed. Mark Philp (Oxford: Oxford University Press).

Paxton, W. (ed.) (2003) Equal Shares? Building a Progressive and Coherent AssetBased Welfare Policy (London: Institute for Public Policy Research).

Pettit, P. (1999) Republicanism: a Theory of Freedom and Government (Oxford: Oxford University Press).

Proudhon, P. J. (1994) What is Property? (Cambridge: Cambridge University Press).

Raventós, D. (2007) Basic Income: the Material Conditions of Freedom (London: Pluto Press).

Rawls, J. (2001) Justice as Fairness: a Restatement (Cambridge, MA: Harvard University Press).

Rousseau, J. J. (1997) The Social Contract and Other Later Political Writings, ed. V. Gourevitch (Cambridge: Cambridge University Press).

Skinner, Q. (1997) Liberty Before Liberalism (Cambridge: Cambridge University Press).

Spinoza, B. de (2005) A Theologico-Political Treatise and A Political Treatise, ed. R. H. M. Elwes (London: Dover).

Stedman Jones, G. (1983) 'Rethinking Chartism', in Languages of Class: Studies in English Working Class History 1832-1982 (Cambridge: Cambridge University Press).

Stedman Jones, G. (2004) An End to Poverty? A Historical Debate (London: Profile Books).

Thompson, E. P. (1962) The Making of the English Working Class (London: Penguin Books).

White, S. (2001) 'Rediscovering republican political economy', Citizen's Income 
Newsletter, 1: www.citizensincome.org/filelibrary/Archived\%20Newsletters/ 2001\%20Issue\%201.pdf (accessed 15 July 2008).

White, S. (2003) The Civic Minimum (Oxford: Oxford University Press).

White, S. (2007) 'Is republicanism the left's "big idea”?' Renewal, 15 (1).

Winch, D. (2002) 'Commercial realities, republican principles', in M. van Geldern and Q. Skinner (eds), Republicanism: a Shared European Heritage, vol. 2 (Cambridge: Cambridge University Press). 


\title{
Economic democracy instead of more capitalism: core historical concepts reconsidered
}

\author{
Adrian Zimmermann
}

\begin{abstract}
Introduction
“"More capitalism" or "economic democracy" are . . the signposts at the crossroads where the Swedes will have to make a choice during the 1980s', the Swedish political scientist Walter Korpi wrote in 1983 (Korpi 1983: 3). Today we know only too well where the journey went and not only in the stronghold of social democracy in the North. Everywhere in Europe the social democratic left was driven back into defensive positions during the 1980s and 1990s. In the short-lived revival of centre-left governments at the end of the 1990s, most of them did not even try to stop the trend towards 'more capitalism', let alone develop ambitions of 'economic democracy'.

In purely defensive struggles, however, trade unions were often quite successful. Here Switzerland offers some striking examples, although it is far from being a social democratic stronghold like Sweden. The Swiss unions defeated in referendum votes neo-liberal attempts to deregulate labour legislation in 1996; the supply of electricity in 2002; and the first pillar of the old age pension system - a universal pay-as-you-go social insurance covering basic needs - in 2004. It is part of the tragedy of contemporary social democracy that it is not able, or perhaps in some cases also not willing, to transform these defensive successes of the trade unions into new strategies for social democratic change in economic and social relations. As the left wing of the Social Democratic Party of Switzerland argued, for example, the successful referendum against the deregulation of the supply of electricity should have been an important occasion to start a debate about the concepts of economic and industrial democracy. ${ }^{1}$ The defence of public services has proved to be a popular issue-in contradiction to everything mainstream opinion leaders (including those on the left) say. But the successful defence of public services should also be taken as a starting point for a new move forward in the struggle to extend democracy from
\end{abstract}


the political to the economic spheres of society. Even the biggest defensive victories against neo-liberalism will only have a limited effect if labour does not succeed in breaking the mega-trend towards 'more capitalism', which is at the root of the neo-liberal project.

Studying the history of socialist and democratic theories is an important precondition for articulating and popularising these theories in contemporary politics. This chapter therefore takes a historical approach. It evaluates some of the more important projects of economic and industrial democratisation in the past. Its focus is on projects in highly developed capitalist states with a democratic constitution. Space does not allow an analysis of reformminded forces in the nations formerly dominated by communist parties (e.g. the Yugoslav system of self-management; the council movement in the Hungarian uprising of 1956; or the reforms during the 'Prague Spring') or initiatives in the developing world. Instead, the chapter focuses on those developments that were most influential in the capitalist West: first, guild socialism in Britain and the combination of the council movement and socialisation in Germany and Austria after the First World War; second, the international socialist discussion on 'plannism' in the 1930s; and third, in the 1970s, attempts to strengthen 'co-determination' in West Germany and to introduce wage earners' funds by the Swedish trade unions.

\section{The German experience}

Economic democracy is indeed often closely associated with the German system of co-determination. I would argue, however, that German-style co-determination can only realise a very limited democratisation of the economy. In essence, 'co-determination' refers to the involvement of employee representatives in company decision-making, either through democratically elected works' councils or the representation of workers in the strategic leadership of large companies. The main benefit of the representation of workers in supervisory boards is that they are better informed about company decisions. One beneficial effect of such a legally regulated works' council system is that it can strengthen both trade union recognition by employers and internal democracy inside unions (Fishman 1997: 39).

However, the ability of workers in Germany to actually co-determine decisions remains limited by economic and legal constraints. The co-determined companies have to face competition from companies without co-determination on international markets, and legally the co-determination law still assures a majority for the representatives of the shareholders in critical cases. Several cases where trade unionists and works councillors represented on supervisory boards were not able to resist 
the temptation of corruption have moreover shattered the credibility of the system. Meanwhile, the 'dual system with separate spheres for unions and works councils' has for a long time primarily acted 'to complement the "responsible" wage bargaining of the unions by encouraging a collaborative search for positive-sum outcomes at company level'. However, in the last two decades it has quite often led to 'company-level productivity coalitions ... which could undercut the unions' own official policies' (Hyman, 2001: 120, 129). The German institutions are therefore one possible way to advance greater workers' participation in economic decision-making but not the only one.

\section{From political to social democracy}

The concept of industrial democracy was probably first used in 1897 by Beatrice and Sidney Webb in their book Industrial Democracy (Vilmar 2002: 41). The notion for them merely meant trade union activity and free collective bargaining. The concept of industrial democracy used in this chapter is the far more ambitious socialist project of democratising economic life by ensuring worker participation in industrial decision-making. As Fritz Naphtali has argued, it was not a mere "coincidence in the development of ideas' that the notion of industrial democracy only became relevant in daily political work after the First World War, since 'the idea of economic democracy could only come into being in a nation when labour in this country already had a certain amount of experience with political democracy' (Naphtali 1977: 22-4). In an earlier historical stage the labour movement - and even Marx and Engels in the Communist Manifesto - assumed that political democracy would immediately lead to workingclass rule. Only after the labour movement had gained more experience of political democracy - and in most countries this was only the case after the First World War - did it become clear that bourgeois rule could still persist in a democratic state.

Naphtali's book Wirtschaftsdemokratie, the classic in the debate about industrial democracy, was a strategy for the German socialist labour movement in the short economic boom of the 'roaring twenties' between 1923 and 1929 (Naphtali 1977 [1928]). It can be seen as a comprehensive summary of the socialisation literature of the period following the First World War (Krätke 2002: 61). Interestingly, co-determination at company-level played only a marginal role in Naphtali's conception (Bontrup, 2005: 129-30). Naphtali argued that works' councils could only become true institutions of economic democracy in an 'organised' economy controlled by the unions. Without this framework, their role remained limited to controlling how laws and collective agreements were 
put into practice at company level (Naphtali 1977: 172-4). Naphtali's comprehensive conception of economic democracy went far beyond demands for workplace co-determination. It also included the extension of the public and co-operative sector of the economy; the democratisation of international, national, regional, local and branch-wide economic chambers, associations and cartels; and the further development of social legislation (Naphtali 1977: 194-200).

Naphtali's statement on the necessity of political democracy as a base for the development of a campaign to democratise the economy is well illustrated by Switzerland where universal (male) suffrage had existed at a national level from 1848. Albert Steck, one of the founding fathers of the Social Democratic Party of Switzerland, wrote reflections on economic democracy which were very close to later discussions; he placed industrial democracy at the centre of his definition of social democracy as early as 1890: 'We want . . social democracy which . . . also includes political democracy as one of its essential parts. Social democracy is an allembracing rule of the people and can only be achieved through the rule of the people over the nation's means of production' (Steck 1890: 118). It is in this basic thesis that the most striking relevance of industrial democracy for a modern social democratic policy is to be found. In my view, social democracy - literally understood as a movement struggling to democratise the whole of society - is simply not possible without industrial or economic democracy (for further reflections along these lines, see Chapter 13 in this book). Democratising the economy is inextricably linked to preserving and sustaining the welfare state. It is no coincidence that the failure of the last serious attempts to democratise the economy in the 1970s and 1980s led to a reactionary counter-offensive against Keynesianism and the welfare state. Even inside social democratic parties, social-liberal tendencies have developed which discard not only the aim of a democratic-socialist transformation of society, but along with it a credible and consistent position defending the historical achievements of the labour movement. Moreover, industrial democracy and social democracy are both necessary for sustaining political democracy. This is even more evident today than it was one hundred years ago in light of the loss of sovereignty of the nation-state - the main space for political democracy - through the process of globalisation. The concentration of economic power within one nation-state, for example Berlusconi in Italy, can also undermine a democratic political culture.

\section{The debate on socialisation after the First World War}

The period following the First World War and the Russian, German and Austrian revolutions marked the first zenith of economic democracy. The 
reason for this was twofold. First, the institutions of the war economy had already established a significant level of state planning, centralisation and regulation within the framework of capitalist economies. Trade unions' involvement in this process had been critical - particularly in Britain and Germany. Without union leadership, the effective functioning of the war economy would have been impossible (Fishman 1997: 32). In the first years after the First World War, there appeared to be the political will to retain some of these war-economy institutions for peaceful purposes instead of going back to 'free enterprise'. But the political motivations for this differed greatly. While many socialists saw in the war economy institutions a nucleus for a socialist economy, bourgeois technocratic reformers like the German Walther Rathenau viewed them primarily as a means to increase productivity (Maier 1981: 336). Second, there was the pressure of the revolutionary council movement in Eastern and central Europe, and also a more militant form of trade unionism in the entente and neutral countries. Besides the German and Austrian Räte, there were also the consigli di fabbrica in northern Italy and the shop steward organisations in Britain (Maier 1981: 334-6). These were a manifestation of a degree of mobilisation and radicalisation not seen before the war. The political strikes organised by the German council and socialisation movement between January and April 1919 put industrial and social democracy - viewed as a necessary base to defend the young German political democracy - squarely on the political agenda (Oertzen 2004: 345-51). The lack of food, shelter and other basic goods had also led to a militant mobilisation of consumers during the war, mainly initiated by women with a working-class background. ${ }^{2}$ As a result of these developments, expert commissions studying the question of socialisation were established in many states. However, in the post-war crisis between 1920 and 1923 the bourgeoisie regained most of its strength and ambitious socialisation projects remained mostly on paper. A crucial exception was the Betriebsrätegesetz of 1920 in Germany (an act concerned with industrial councils). It was in origin a concession to the far more radical aims of the council-movement of spring 1919 (Oertzen 2004: 248-9).

It is often forgotten that the German and Austrian theoretical discussions of industrial democracy in this period were inspired by British 'guild socialism', as developed in the work of G. D. H. Cole. Guild socialism for the first time explicitly made the distinction between on the one hand 'industrial democracy' and the genuine socialisation of the means of production, and on the other nationalisation (i.e. management by a state bureaucracy as in the pre-1914 state-owned railways in Prussia and other European countries and later in the Soviet Union's comprehensive nationalisation of industry). Guild socialism also differed from syndicalism in the sense of a takeover of enterprises by the workers. While guild socialism had 
originated in syndicalism and therefore had a strong emphasis on workers' control, it also stressed the importance of consumer representation, which it saw as a 'natural' duty of the state (Hirst 1994: 101-10). While under guild socialism the state as the representative of consumers was to own the socialised industries, these would be administered by industrial unions transformed into the new form of 'guilds'. Workers' control of products and production would thus be established and the wages system abolished (Cole [1917] 1972).

As Rudolf Hilferding argued in his foreword to a German translation of Cole's Self-Government in Industry, guild socialism offered a synthesis between the syndicalism of the French trade unions and the American Industrial Workers of the World and the collectivist approaches of the Fabians and other more statist interpretations of socialism (Hilferding 1921: iv-ix). In the words of the leading 'Austro-Marxist' thinker Otto Bauer, who, after the Austrian revolution, was Austrian minister for foreign affairs and socialisation for a short time in 1918-19, 'guild socialism transmitted the historical experience of English democracy' and its characteristic system of local self-government 'from the political to the social area'. Bauer developed his own concept of socialisation. It was strongly inspired by the main assumptions of guild socialism, although he did not copy it in every detail. He conceived of industrial democracy and not Russian-style war communism or the dictatorship of Soviets as being the way to socialism for central and Western Europe (Bauer 1920: 328-30). He also rejected state management of industry, fearing that it would lead to a concentration of executive power which would be dangerous in any democracy. According to Bauer, the socialist aim was thus not limited to mere 'nationalisation' (Verstaatlichung), but was rather a genuine 'socialisation' (Vergesellschaftung). In his concept of socialisation an institution which is also the focus of today's discussion about corporate governance played a key role: 'Every socialised industry will be led by a board of directors; but this board of directors will no longer be elected by the capitalists, but rather by those groups in the population whose needs the socialised industry will then have to satisfy'. Boards of directors of socialised industries should therefore consist of representation in thirds: 'A third of the members of the board of directors ... is determined by the trade unions. A second third . . . is formed by the representatives of consumers. The final third of the members of the board of directors comprises the representatives of the state' (Bauer 1919: 96-7).

But none of these ambitious projects were realised. And with the rise of fascism first in Italy and then in Germany and Austria, there was the imminent threat that the contradiction between capitalism and democracy would be 'solved' by abolishing democracy in the political sphere. 
The fascist regimes used the dictatorial power they had obtained with the help of the big corporations and old aristocratic elites to crush violently the labour movement and all elements of industrial democracy - free collective bargaining and works' councils - which had been achieved in the 1920s (Hyman 2001: 146).

\section{Industrial democracy and plannism}

In the 1930s, democratising the economy was an important aim of the international movement for 'Labour Plans'. The plannist movement was conceived as an alternative to the activist propaganda of fascism for both public investment programmes and an authoritarian 'corporate order'. Influenced by the WTB-Plan of the German Trade Union Confederation of $1932^{3}$ the Belgian psychologist and revisionist socialist Hendrik de Man wrote the first 'Labour Plan' for the Belgian Labour Party (POB, BWP) in 1933. A spin-off of the Belgian plan was the invitation from de Man and Hans Oprecht, the general secretary of the Swiss public sector union, to plannist thinkers from different European countries to meet in the Abbey of Pontigny in northern France in 1934. In 1935 the Swiss, Dutch and Czechoslovakian social democratic parties also adopted 'Labour Plans'. The Socialist Party of Switzerland published a new version of its plan in 1942. Named the 'New Switzerland', this document had an even stronger focus on industrial democracy and stressed what it called 'the free, co-operative tradition' of Switzerland. It was the most important but also the last programme of structural reform to be published by Swiss social democracy.

Of striking relevance to our contemporary situation remains the combination put forward by the different Labour Plans of industrial democracy and a quasi-Keynesian anti-crisis strategy promoting the purchasing power of both the industrial working class in a strict sense as well as other allied social groups, such as white collar workers, small farmers and the selfemployed. However, the plannist concept was not translated into action in any of the countries where the labour movement, or parts of the movement, had adopted it. De Man's shattered hopes of realising the plan in the framework of democracy led him to become an admirer of the allegedly 'organising' and 'anti-capitalist' practices of the fascist regimes (Pels 1985: 148-50; Sternhell 2000: 343). He thus moved closer to anti-Marxist, activist and technocratic-elitist thinking. This tendency peaked in a short and unsuccessful attempt at collaborating with the Nazis during the occupation of Belgium in 1940.

However, de Man's drift to the right did not invalidate his earlier convincing attempts to claim the then fashionable notion of 'corporatism' for the left. In his pamphlet Corporatisme et Socialisme he pointed to the existence 
of free trade unions and political equality as the decisive elements distinguishing democratic corporatism, to which the labour movement should aspire, from the authoritarian corporatism promoted by fascism (Man 1934: 32-4). It is evident that institutions of economic self-government are not a danger to political democracy per se. They can become a threat, however, when they are used to usurp parliament's key functions instead of complementing it in areas that hitherto have not been part of democratic decision-making. A strategy for industrial democracy therefore also has to defend political democracy. And it has to remain in touch with the defence of the economic interests of the working class. This was precisely what was lacking in de Man's thinking. In his 'psychological' revision of Marxism in the 1920s he considered exploitation as an ethical rather than an economic problem. This approach was already being disseminated by Mussolini, who shared with de Man and the German sociologist Robert Michels - a convert from syndicalism to fascism - common ideological roots in the 'revolutionary revisionism' of the French syndicalist thinker Georges Sorel (Sternhell et al. 1999: 310-12).

\section{Economic democracy after the Second World War}

The power of the trade unions was strengthened after the Second World War in many countries. In the immediate post-war period there was a strong tendency to the left. Capitalism was perceived as the system that had led to two world wars, the Great Depression and fascism. It was therefore widely believed that it ought to be replaced by an alternative social system. Consequently, there were radical reforms strengthening some elements of industrial democracy in many countries.

While in the United Kingdom, France, Italy and Austria there was a wave of nationalisations in key industries, in Germany co-determination at the company level was strengthened:

The industrial tycoons who had made their peace with Hitler - indeed had helped him to power - were discredited, and initially there was consensus among the occupying powers that the former concentration of economic ownership in private hands must never again be permitted. The trade unions were seen as the most reliable guarantors of a new, democratic Germany, not least by the Labour government in Britain. (Hyman 2001: 117)

The 'basic programme' of the German Trade Union Confederation of 1949 called for a comprehensive strategy for economic democracy in the sense used by Naphtali. It included not only co-determination at all levels of the economy, but also the socialisation of key industries. In the political climate of the cold war, however, such a strategy could no longer gather political support. The British occupation authorities finally accomplished 
their reform of the strategic German iron, steel and coal industries not by public ownership, but by breaking up the huge conglomerates into smaller companies and by "employee representation on the company supervisory boards and the appointment of a trade unionist as "labour director" in the management team' (Hyman 2001: 117).

These union rights gained under allied occupation were retained by the Adenauer Government after serious strike threats had been made by the German Trade Union Confederation. In exchange, trade union leader Hans Böckler, in direct talks with Adenauer, tacitly accepted the foreign and defence policy which was leading the Federal Republic into the Western bloc (Bontrup 2005: 134). Outside the mining and steel industries the 1952 Industrial Constitution Act (Betriebsverfassungsgesetz) was much more moderate. It largely re-enacted the legal framework of 1920 which had been abolished by the Nazis in 1933. The unions had demanded more influence in works' councils, including for works' councils to have 'significant veto powers over management decisions', and for trade union nomination rights for the workers' representatives on supervisory boards (in companies with more than 500 employees outside iron, coal and steel, one-third of the members of these boards had to be workers' representatives). But these demands could not muster a majority in parliament. In the final vote, they were rejected by both social democratic and communist parliamentarians (Hyman 2001: 117-18; Bontrup 2005: 135-6; Oertzen 2004: 255-7).

The expectation that the post-war reconstruction period would lead to the victory of the interventionist concepts of the left over the capitalist free market was frustrated as the 'golden age' of capitalism got under way (Hobsbawm 1994). Instead there was a revival of 'pro-market views' (Sassoon 1997: 190). German co-determination remained restricted by this political climate for many years. With the 1959 Bad Godesberg programme the political vision of the SPD became that of a "co-decided market capitalism' (Höppner 2005: 216). ${ }^{4}$ It thus replaced an autonomous policy for the control of economic power with the conception of a 'social market economy' coined by the Christian-Democratic minister Erhard (Höppner 2005: 215; Hyman 2001: 118-19). But the left wing of the German trade union movement led by the president of the metalworkers' union, Otto Brenner, still strived for and further developed a more comprehensive approach to industrial democracy, including public ownership of key industries and democratic planning (Vilmar 2002: 40-2; Hyman 2001: 121-2).

\section{Projects of co-management and self-government in the 1970s}

At the end of the 1960s there was a revival of the debate on industrial democracy. In particular, the projects proposed by oppositional left forces in 
the Soviet bloc were widely discussed, for example the ideas of the economics minister in the 1968 'Prague Spring' government, Ota Šik. Willy Brandt even won the West German elections of 1969 under the slogan 'let's dare more democracy'. One of the projects of his social-liberal coalition was an amendment to the Industrial Constitution Act in 1972. This brought about clear progress in co-determination: 'enhanced powers for works' councils, including influence over the working environment; and closer formal links between unions and councils. The number of works' councillors entitled to release from their normal duties was increased, and a new institution - the central works' council - was made mandatory in multi-plant companies' (Hyman 2001: 126). The Co-Determination Act of 1976, enacted during Helmut Schmidt's chancellorship, extended restricted parity codetermination beyond the borders of the iron, steel and coal industries. Now, in companies with 500-2,000 employees, one-third of the members of the supervisory board had to be workers' representatives, while in those companies with more than 2,000 workers, half of the members of the supervisory board had to represent the workforce. However, this

\begin{abstract}
gave the unions a victory in form but a defeat in substance ... one employee representative was to be chosen by middle managers (leitende Angestellte); while the chair of the supervisory board, who possessed a casting vote, could be appointed by the shareholder nominees alone if there was otherwise no agreement. Even this, however, was too much for many employers; many large firms subdivided their operations in order to evade the high size threshold, while in 1977 a number of companies and employers' associations brought a complaint to the constitutional court (rejected in 1979). (Hyman 2001: 126)
\end{abstract}

In 1999, 679 companies employing approximately 2.1 million workers operated with this form of parity co-determination. To put this into perspective, about 2 million companies employing approximately 34 million workers were operating in Germany during the same year (Bontrup 2005: 136-8).

Meanwhile, in France the left union alliance of socialists, communists and the left wing of the radical party urged far-reaching nationalisation and self-management (autogestion) rights in their common programme of July 1972. After the victory of the left in the 1981 elections, the programme was partially enacted (Sasson 1997: 538-40, 551-2, 563-4). However, the government reacted to pressures from the financial markets with a sharp swing to the right in 1983. This volte-face marked the end of this conjuncture of industrial democracy not only in France but in the whole of Europe. ${ }^{5}$

A major problem of the industrial democracy debate in this period was that the renewed self-confidence of trade unions and their commitment 
to industrial democracy remained virtually isolated from the upsurge of utopian experiments in the new social movements. For example, both solidarity movements with the third world and the ecological movement established cooperative shops dealing with fair-trade or organic products and in many European countries autonomous youth centres tried to challenge the music business. The separation between these civil society initiatives and the trade unions meant that it was no surprise that the former often ended, as many other cooperative experiments had done before, either by retreating back into another large corporation or merely becoming an ordinary bourgeois enterprise.

\section{Investment funds and industrial democracy: the experience of the Swedish wage earners' funds in the 1970 s}

Several recent socialist thinkers have argued that the basis of a future socialist mode of production lies in investment funds (Kremer 1998; Krätke 1997; Aglietta/Rebérioux 2005; Sjöberg 2004). In this context, the potential power of wage earners as shareholders through the growing importance of corporate and semi-public pension funds is often mentioned. The experience of the Swedish labour movement in what was probably the most ambitious plan for democratising the economy through collective capital formation in workers' controlled investment funds is therefore highly relevant (for further discussion, see Chapter 6 of this book)

In 1971 the Swedish trade union confederation (the LO) adopted a programme for co-determination and industrial democracy. At the core of the LO's conception of industrial democracy was a plan for investment policy elaborated by Rudolf Meidner, the leading intellectual of the Swedish labour movement and in the 1950s one of the authors of the Rehn-Meidner model for the Swedish solidaristic incomes policy. Through the means of so-called 'wage earners' funds' (löntagarfonder) the private sector would be placed under the gradually stronger control of the workers and their unions. According to this plan, 20 per cent of the annual profits of firms with more than fifty employees was to be transmitted to the funds in the form of additional shares. According to Meidner's calculations, the funds would have accumulated a majority of firms' capital in approximately twenty to forty years.

The context of this revival of industrial democracy among the Swedish trade union leadership was the increasingly paradoxical results of the solidaristic wage policy. It created 'excess profits, since the wages of the workers in the more profitable industries were kept lower than they would otherwise be, in deference to the principle of relating pay to the work performed and not to the employer's ability to pay' (Sassoon 1997: 707). 
Workers' discontent with this situation was expressed in a wave of mostly wildcat strikes between 1969 and 1971. The proposed wage earners' funds were to ensure that wage restraint and high profits in these most profitable firms would be compensated for by the funds, within which greater workers' influence would become 'an alternative to controlling wages through unemployment - the solution adopted by the right throughout Europe' (Sassoon 1997: 706-8, 375).

Although originally conceptualised as complementary to the solidaristic wage policy, the Meidner plan nevertheless signified a step in a qualitatively different direction; it went to the heart of the capitalist mode of production (Sjöberg 2004: 31). Its project was fundamentally different from other profit-sharing models because it aimed not only at giving workers a share of the profits but also, in the long run, at giving them control over the means of production. The plan was accepted in principle by the Swedish Parliament in 1976. In the same year, however, the Swedish social democrats lost power in parliamentary elections for the first time since the 1930s (Sassoon 1997: 709; Sjöberg 2004: 36).

\section{The failure of the wage earners' funds in the 1980s as a 'hegemonic turning point'}

In subsequent years the forward march of Swedish labour became a retreat. The idea of the wage earners' funds had originated in a phase of radicalisation within the Swedish unions (1971-76). However, the public and parliamentary debate on the funds (1976-83), as well as their existence in the diluted form of several smaller regional funds shorn of their original anti-capitalist ambitions (1983-91), occurred at a time when labour was in a defensive position. The bourgeois bloc used the widespread fears of the wage earners' funds among the middle classes, and white collar workers in particular, to retake its 'hegemonic power' and thereby finally succeeded in destabilising the whole 'social-democratic model of welfare', the so-called 'people's home' (Folkshemmet). Sjöberg argues that precisely because labour did not succeed in moving from the welfare state to industrial democracy, the resulting social conditions enabled these groups to undermine the major historic achievements of the labour movement (Sjöberg, 2004: 31). The wheel of history turned backwards. Although most other European countries lack such concrete experience with a scheme to accumulate capital for workers, this thesis may be generalised. It might be one of the central political reasons for the success of neo-liberalism and also for the partial recognition of some of its major ideological mantras by important parts of the social democratic leadership in many countries. 


\section{Social funds as a future form of collective capital formation?}

Besides growing difficulties in controlling investment nationally at a time when financial markets were increasingly becoming globalised, a crucial weak point of the wage earners' funds from the outset was their essentially syndicalist character. Large proportions of the population were excluded from participation in them, a point that bourgeois counter-propaganda successfully stressed (Sassoon 1997: 712-13). But the wage earners' funds were far from being the only initiative in that period that suffered from a productivist and syndicalist bias. It is notable that the discussions on industrial democracy after the Second World War were in most cases limited to demands for more workers' co-determination rights and greater public control. The demands for consumers' representation which had been so prominent in the discussion from 1919-29 and even to a certain extent in the plannism of the 1930s and 1940s had virtually vanished by the 1950s. This could perhaps be related to the fact that while at the end of the First World War a militant consumer movement mainly led and formed by women had existed, this was no longer the case after 1945. When the environmental and 'Third World' solidarity movements of the 1970s started trying to win the support of consumers for their aims, neither they nor the unions were willing to forge an alliance with each other. Today, however, the conditions for a coordinated mobilisation of workers and consumers are more auspicious.

To pre-empt the problems of syndicalism, Sjöberg argues for so-called 'social funds' which should be able to combine two elements. First, what he calls the 'elegant construction presented by Meidner', which was able to bring about a shift in property and power structures at the corporate level without negatively influencing the financial liquidity of these corporations. Second, a new form of management of the funds that would guarantee a balance between producers and consumers. Trade union pension funds could also play some role in social funds, provided 'that labour acts as a unified hegemonic force' (Sjöberg 2004: 35). An important element of the strategy of these funds would be the coordination of regional and national funds at an international level. ${ }^{6}$ Sjöberg acknowledges that such an international strategy has not yet been elaborated (2004: 36). This idea therefore needs continuous discussion and theoretical development. Might an international social fund system even be a form adapted to the challenges of globalisation in the "commonwealth of the economy'7 that Naphtali thought to be a necessary precondition for industrial democracy (1977: 162)? Other important elements for the democratic control of transnational corporations could be the expansion of International Framework Agreements (IFAs) already concluded today between some transnationals 
and some Global Union Federations (Gallin 2005). Both international NGOs and UN organisations could play a role here in representing consumers.

\section{Contemporary debates}

Since 1989 discussions about the fact that the means of production remain in private hands, and about which class controls economic power have evidently played only a minor role in debates inside either social democratic parties and trade unions. In academic discourse, however, some newly developed approaches have emerged which merit wider discussion. One could cite here the concept of 'associative democracy', which as a 'real third way' incorporates some elements of guild socialism and asks questions about the possibility of democracy beyond the state (Hirst 1994). There is also the utopian concept of a 'participatory economy' (Parecon), inspired by the anarcho-syndicalist tradition and discussed by the movement for alternative globalisation and at the World Social Forums (Albert 2004). On a more practical level, an increasing number of industrial struggles against factory closures and the 'outsourcing' of production have directly focused on decisions about investment and corporate governance, thus breaking through the traditional boundaries confining collective bargaining and labour disputes to wages and working conditions. In the bargaining process for social plans to moderate the effects of industrial change, workers and their unions already accept responsibility for strategic corporate leadership. They have to challenge the strategies of a new generation of managers who orient their decisions to the short-term profit interest of shareholders with their own perspective on the future of often highly productive industries (Aglietta and Rebérioux 2005). Today these conflicts between workers, management and shareholders on investment policy are in most cases treated as isolated instances by both labour market actors and public authorities. However, when workers mobilise to influence strategic decisions on investment, they have already brought economic democracy back onto the political agenda. It is therefore a central challenge for the trade unions and all progressive forces to aggregate the experience of these struggles and to produce a new strategy for economic democratisation.

\section{Conclusion: the past and the future}

The history of the project of 'industrial democracy' has crucial relevance for the present. The rediscovery of forgotten alternatives can stimulate future offensives. An accurate analysis of the failure of the major experiments for democratising the economy can optimise the chances of future projects succeeding. Although it is of course not possible to deliver instant 
solutions, I will offer some provisional conclusions about rethinking industrial democracy.

First, new attempts at democratising the economy will have to be more strongly embedded in the actual struggles of the labour movement than most of the earlier projects were. When concepts of industrial democracy are no longer consciously oriented to the interests of the working class, there is a great danger that they will become reactionary. Here, Hendrik de Man's desertion to fascism and the neo-liberal takeover of elements of the worker self-management thinking of the 1970s are warning signals.

Second, at a theoretical level Michael Krätke has convincingly argued that discussions of industrial democracy, the reform of political democracy (as in the debate on 'associative democracy') and market socialism, which until now have been virtually separate, should be brought together (Krätke 2003: 61-2).

Third, projects for industrial democracy will have to analyse the scope for socialist and trade union action under the current conditions of capitalist development, in which internationalisation and the financial sector play a more important role than in earlier stages (Bischoff 2006: 138-9).

Fourth, taking into account the structural changes of the last thirty years, a reconsideration of the Swedish wage earners' funds seems to be a particularly promising line of inquiry. Their very convincing model of a step-by-step socialisation of the means of production avoids disruptive side effects such as a shortage of liquidity.

Fifth, new models of industrial democracy will have to retain the distinction between genuine socialisation and the more limited approaches of both syndicalism and nationalisation, evident in the British discussion about guild socialism and the socialisation debate in Germany and Austria after the First World War. By this I mean that they should concentrate on the development of organisational structures which enable a balanced representation of producers, consumers and the public interest. These new models of industrial democracy will also have to retain the combination of democratising investment decisions and quasi-Keynesian anti-crisis investment programmes from the plannist approaches of the 1930s and 1940s.

Sixth, future projects of industrial democracy must learn from the discussion about humanising the workplace and the self-management of production which took place in the 1970s in order to place greater stress on the individual worker's needs and goals (Müller 2006: 113-14).

Overall, economic democracy - understood not as an another version of utopia, but as a fruitful tradition which social democracy has to rediscover and redevelop - could be a crucial element in reconciling the two basic aims of social democratic policy: economic modernisation and social security, which have too often drifted apart in the last two decades. By doing this 
- and surely not by giving in to the neo-liberal Zeitgeist - social democracy could prove that it is still the political force that alone is capable of extending the great achievements of liberal democracy to all members of society. Or, as Albert Steck so aptly stated at the end of the nineteenth century: 'As the old liberalism has brought down political class rule through political democracy so social democracy as the new liberalism has to bring down economic class rule through economic democracy. Social democracy is the daughter of genuine liberalism but not of the liberals' (cited in Bieler 1960: 126).

\section{Notes}

1 Some of the documents relating to this discussion can be downloaded (in German and French): www.socialism.ch.

2 For two examples of consumers' militancy from neutral countries (the Netherlands and Switzerland), see Kuypers 2002: 97-9; Pfeiffer 1993.

3 Named after the initials of its authors (Wladimir Woytinski, Fritz Tarnow and Fritz Baade), this plan 'put forward a large-scale public works programme with counter-cyclical aims, to be financed by deficit spending ... By intervening with concrete legislative proposals, the WTB Plan contravened one of the principles of the division of labour between the SPD and the unions. Hilferding opposed it because it was 'unMarxist' - in reality because the SPD . . . was afraid that the plan would antagonise the Chancellor, Brüning' (Sassoon 1997: 60). For the influence of the WTB-Plan on de Man, see Sassoon 1997: 68.

4 'mitbestimmter Marktkapitalismus'.

5 It is interesting that it was the originally catholic, but since the 1960s socialistleaning, trade union confederation CFDT which was the main advocate of autogestion (self-management) and which later became the "champion of the modernising "second left" which surged after the failures of 1981-82' (Sassoon 1997: 564). This social-liberal tendency was led by Jacques Delors and Michel Rocard and can to some extent be seen as a forerunner of New Labour.

6 It can be noted here that the International Confederation of Free Trade Unions (ICFTU), the Global Union Federations (GUF) (formerly the International Trades' Secretariat) and the Trade Union Advisory Commission at the OECD (TUAC) have founded a joint committee to discuss the coordination of the investment of capital owned by workers: www.workerscapital.org/. In the USA the AFL-CIO has tried for some years to coordinate the investment policy of pension funds: www.aflcio.org/corporatewatch/capital/whatis.cfm.

7 'Gemeinwesen der Wirtschaft'.

\section{References}

Aglietta, M. and Rebérioux, A. (2005) 'Vom Finanzkapitalismus zur Wiederbelebung der sozialen Demokratie', Supplement der Zeitschrift Sozialismus Heft 3. 
Albert, M. (2004) Parecon: Life after Capitalism (London and New York: Verso).

Bauer, O. (1919) Der Weg zum Sozialismus, reprinted in Otto-Bauer-Werkausgabe Bd. 2 (Wien: Europaverlag).

Bauer, O. (1920) Bolschewismus oder Sozialdemokratie?, reprinted in Otto-BauerWerkausgabe Bd. 2 (Wien: Europaverlag).

Bieler, P. (1960) Albert Steck 1843-1899. Der Begründer der Sozialdemokratischen Partei der Schweiz (Olten: Hauenstein-Verlag).

Bischoff, J. (2006) Demokratisierung der Wirtschaft - ein historischer Irrtum?, in H. J. Bontrup and J. Müller (eds), Wirtschaftsdemokratie. Alternative zum ShareholderKapitalismus (Hamburg: USA).

Bontrup, H. J. (2005) Arbeit, Kapital und Staat. Plädoyer für eine demokratische Wirtschaft (Köln: PappyRossa).

Bontrup, H.-J. (2006) Die Wirtschaft braucht Demokratie, in H. J. Bontrup and J. Müller (eds), Wirtschaftsdemokratie. Alternative zum Shareholder-Kapitalismus (Hamburg: USA).

Bontrup, H. J. and Müller, J. (eds) (2006) Wirtschaftsdemokratie. Alternative zum Shareholder-Kapitalismus (Hamburg: USA).

Cole, G. D. H. (1920a) Chaos and Order in Industry (New York: Frederick A. stokes co.).

Cole, G. D. H. (1920b) Guild Socialism Re-Stated (London: Leonard Persons).

Cole, G. D. H. (1972) Self-Government in Industry (with an introduction by J. Corina, 1st edn, 1917) (London: Hutchinson Educational).

Fishman, N. (1997) 'Reinventing corporatism', Political Quarterly, 68.

Gallin, D. (2005) 'Demokratische Kontrolle transnationaler Konzerne': www.globallabour.info/de/2008/06/demokratische_kontrolle_transn.html.

Hilferding, R. (1921) 'Einleitung', in G. D. H. Cole, Selbstverwaltung in der Industrie (Nach der fünften neubearbeiteten Auflage übersetzt von R. Thesing) (Berlin: Engelmann).

Hirst, P. (1994) Associative Democracy: New Forms of Economic and Social Governance (Cambridge: Polity Press).

Hobsbawm, E. (1994) Age of Extremes: the Short Twentieth Century 1914-1991 (London: Michael Joseph).

Höppner, M. (2005) 'Sozialdemokratie, Gewerkschaften und organisierter Kapitalismus. 1880-2002', in P. Windolf (ed.), Finanzmarkt-Kapitalismus. Analysen zum Wandel von Produktionsregimen (KZfSS. Sonderheft 45) (Köln: Vs Verlag für Sozialwissenschaften).

Horn, G.-R. (1996) European Socialists Respond to Fascism: Ideology, Activism and Contingency (New York and Oxford: Oxford University Press).

Hyman, P. (2001) Understanding European Trade Unionism: Between Market, Class and Society (London: Sage).

Janssen van Galen, J., Nekkers, J., Pels, D. and Pronk, J. P (1985) Het moet, het kan! Op voor het Plan! Vijftig jaar Plan van de Arbeid (Amsterdam: B. Bakker).

Korpi, W. (1983) The Democratic Class Struggle (London: Routledge).

Krätke, M. R. (1997) 'Proletarier aller Länder - versichert Euch! Über die Sozialisierung des Sozialstaates', Widerspruch Heft 43, Zürich. 
Krätke, M. R. (2003) 'Wirtschaftsdemokratie und Marktsozialismus', in Mut zur konkreten Utopie. Alternativen zur herrschenden Ökonomie (Kritische Interventionen 8) (Hannover: Offizin).

Kremer, U. (1998) 'Moderner Sozialismus und Wirtschaftsdemokratie', Zeitschrift für Sozialistische Politik und Wirtschaft 100.

Kuypers, I. (2002) In de schaduw van de Grote Oorlog. De Nederlandse arbeidersbeweging en de overheid 1914-1920 (Amsterdam: Aksant).

Maier, C. S. (1981) 'The two postwar eras and the conditions for stability in twentieth-century Western Europe', American Historical Review, 86 (2).

Man, H. de (1934) Corporatisme et socialisme (Paris and Brussels: Labor).

Minns, R. (1996) 'The social ownership of capital', New Left Review, 219.

Müller, J. (2006) 'Ambivalente Subjektivierung als Chance: Wirtschaftsdemokratie aus der Akteursperspektive', in H. J. Bontrup and J. Müller (eds), Wirtschaftsdemokratie. Alternative zum Shareholder-Kapitalismus (Hamburg: USA).

Naphtali, Fritz (1977) Wirtschaftsdemokratie. Ihr Wesen, Weg und Ziel (ed. R. F. Kuda, 1st edn 1928) (Köln and Frankfurt/M.: Europäische Verlangsanstalt).

Oertzen, P. von (2004) Demokratie und Sozialismus zwischen Politik und Wissenschaft (ed. M. Buckmiller, G. Kritidis and M. Vester) (Hannover: Offizin).

Pels, D. (1985) 'Hendrik de Man en de ideologie van het planisme', in J. Janssen van Gallen, J. Nekkers, D. Pels and J. P. Pronk, Het moet, het kan! Op voor het Plan! Vijftig jaar Plan van de Arbeid (Amsterdam: B. Bakker).

Pfeiffer, R. (1993) 'Frauen und Protest. Marktdemonstrationen in der deutschen Schweiz im Kriegsjahr 1916', in A. Head-König and A. Tanner (eds), Frauen in der Stadt (Schweizerische Gesellschaft für Wirtschafts- und Sozialgeschichte Bd. 11) (Zürich: Chronos).

Sassoon, D. (1997) One Hundred Years of Socialism: the West European Left in the Twentieth Century (London: Fontana).

Sjöberg, S. (2004) 'Kollektivfonds als eine Strategie für die Wirtschaftsdemokratie. Lehren aus der Geschichte der schwedischen Arbeitnehmerfonds für die Zukunft', Sozialismus Heft 5.

SDAP/NVV (1935) Het Plan van de Arbeid, Rapport van de commissie uit NVV en SDAP (Amsterdam: Arbeiderspers).

Spieler, W. (2005) 'Wirtschaftsdemokratie heute: Aufruf zur Mitarbeit am "visionären Teil” des Parteiprogramms', links.ch, August.

SPS (1935) 'Der Plan der Arbeit', in Programm der Sozialdemokratischen Partei der Schweiz (Angenommen durch den Parteitag vom 26. und 27. Januar 1935 in Luzern), 15-24: http://al.sp-ps.ch/data/DIV/PP-D/Pp1935-d.pdf.

SPS (1942) Die neue Schweiz. Die Sozialdemokratische Partei an das Schweizervolk! (Zürich).

Steck, A. (1890) 'Die Bedeutung des Wortes "Sozialdemokrat”', Auszug aus Der Schweizerische Sozialdemokrat, Nr. 30, 26.7.1890, in Arbeitsgruppe für die Geschichte der Arbeiterbewegung Zürich, Schweizerische Arbeiterbewegung. Dokumente zur Lage, Organisation und Kämpfen der Arbeiter von der Frühindustrialisierung bis zur Gegenwart, 1989 (Zürich: Limmat-Verlag). 
Sternhell, Z., Sznajder, M. and Asheri, M. (1999) Die Entstehung der faschistischen Ideologie. Von Sorel zu Mussolini (Hamburger: Hamburger Edition).

Sternhell, Z. (2000) Ni droite ni gauche. L’idéologie fasciste en France (Bruxelles: Fayard).

Vilmar, F. (2002) 'Wirtschaftsdemokratie - eine Alternative. Bilanz und Aktualität', Widerspruch 43 (Zürich: Chronos).

Webb, S. and Webb, B. (1897) Industrial Democracy (London: Longmans).

Zimmermann, A. (2005) 'Keine Sozialdemokratie ohne Wirtschaftsdemokratie. Zur Geschichte und Aktualität einer Debatte', Widerspruch 49 (Zürich: Chronos). 


\title{
15
}

\section{Afterword $^{1}$}

\author{
Nina Fishman
}

The idea for three international conferences examining social democracy was conceived by an informal group of British historians in the autumn of 2003. The need for an open-ended, serious examination of the past, present and future of social democracy was self-evident. Sufficient time had elapsed since the Wende to enable flexible, inquisitive historians to venture onto the old terrain of the nineteenth and twentieth centuries to test the preNovember 1989 narratives. $^{2}$ It was also an apposite moment to engage in future-gazing, a pastime in which most historians indulge, and which neuro-physiologists have discovered has a significant social utility.

There was an underlying continuity in the three conferences. They attracted scholars who were seriously interested in the subject across a gratifyingly long timeline. A substantial number of people who attended the first conference at the Institute of Historical Research in London returned as paper-givers and discussants to the second at Swansea University and then to the third at Sheffield University. There were fascinating hindsights from participants who had been young adults at the beginning of the cold war. There were also currently young adults who had never known the cold war.

It was notable that many participants had research specialisms in communism and/or conservatism/Christian democracy as well as social democracy. The resulting intellectual diversity produced exceptionally lively, wide-ranging debate both in the conference sessions and afterwards. It was, perhaps, apt that the plenary speakers for the third conference, held at Sheffield, were Richard Corbett MEP, an exemplary centre social democrat; the Cuban Ambassador; and Ed Miliband MP, now a cabinet minister in Gordon Brown's Government.

As a child of the cold war, I grew up with social democracy and had always taken its existence for granted. As a modern European historian, I had a working knowledge of social democracy's pre-1948 past. But when 
the euphoria of the 1989 springtime of nations had finally dissipated, it was clear that I needed to rethink social democracy. This afterword cannot possibly do justice to the range and depth of papers given and discussions about them which took place at the three conferences. But as a result of attending them, I am conscious of having evolved a new framework within which to place the narrative of social democracy. What follows is my own take and reflections about this intellectual pilgrimage.

\section{What's in a name?}

Like most other abstract political terms, social democracy has had neither a continuous nor a precise definition. Many anglophone historians, past and present, have only construed it literally, as describing those political parties with social democratic in their names. However, after October 1917, when the Russian Social Democratic and Labour Party was renamed as the Communist Party, a presumption of polarity between social democracy and communism prevailed, not only in political discourse but also among academics. Karl Kautsky's polemical denunciation of Leninism emphasised the democratic in social democracy in contrast to the dictatorship of the proletariat in the catechism of the Comintern's twenty-one conditions for affiliation. The Second Socialist International had been founded in 1889; the Third Communist International or Comintern was established in 1919 with the express intention of superseding the second.

A high-profile semantic conflict continued around this polarity throughout the interwar period, with communists declaring their preference for proletarian democracy as opposed to social democracy which had caved in to national jingoism in the First World War and continued to share its bed with capitalism. But in their own defence, social democrats pointed to the secession in April 1917 of Kautsky, Bernstein and others who left the Social Democratic Party (SPD) fraction in the Reichstag to form the Independent Social Democratic Party (USPD). The new party voted against war credits and opposed Germany's continuing prosecution of the war. Social democrats also highlighted the systematic way in which the infant Union of Soviet Socialist Republics was depriving trade unions of independent civil rights and citizens of political freedom. The reality of the dictatorship of the proletariat, they insisted, was a travesty of democratic socialism. ${ }^{3}$

The presumption of a polarity between communism and social democracy survived in a diluted form through the period of the united/popular front against fascism, 1935-39, returning with renewed vigour in August 1939 after the conclusion of the Ribbentrop-Molotov Pact until Hitler's invasion of the USSR in June 1941. For the rest of the Second World War, most social democrats repressed or even discarded their belief in the existence of 
an unbridgeable divide between social democracy and communism. They worked closely with communists in resistance movements in occupied Western Europe and war production campaigns in Britain, Australia and North America. Some social democrats were even willing to acknowledge that they shared a common past and ancestry with communists.

The motivation for social democrats' volte-face was complex and remains largely unexamined by contemporary scholars. Although in large part pragmatic, there was also a strong appreciation of the Soviet Union's military prowess, technological and engineering virtuosity, and economic power, e.g., the Webbs' sanguine perception of Soviet progress (Morgan 2006). The general secretary, Ernest Bevin, wrote in the Transport and General Workers' Union journal, The Record, in April 1933:

In the case of Soviet Russia, who is endeavouring to work out a different economic system from that existing in this country, we have fought determinedly against [British] intervention ... and have done everything in our power to assist her, not withstanding the fact that we have often met with abuse and attack from the Russians themselves. We have done this because we believe that this great economic experiment may considerably influence the development of world planning and social change.

The appreciation of underlying similarities continued into the peace and reconstruction. The most remarkable manifestation of this was the large number of SPD leaders and rank-and-file members who either lived in East Germany and pledged their loyalty to the Socialist Unity Party, a merger of the SPD and German communist party, or emigrated from West Germany to join it. Stalin's death in 1953 precipitated a palpable diminution of cold war tensions after which many Western European social democrats' impulse to reach out to people's democratic parties in Eastern Europe and communists in the USSR and their respective trade unions returned with heightened intensity, e.g., the persistent refusal of the British trade union movement to engage in cold war crusading, causing the American union federations, the AFL and the CIO to consider them soft on communism. In the early 1970s Willi Brandt's determined pursuit of Ostpolitik revealed the potential for more than 'peaceful co-existence'.

British cold war intellectuals and/or politicians who espoused social democracy with zealous rigour (e.g. Crosland, Gaitskell) found its essence in Kautskyist antagonism to communism and its claim to be the sole heir to the socialist tradition. Left-wing socialists frequently accepted this assertion at face value, and equated social democracy with their centreright opponents. For many Labour activists who identified with the Keep Left group of MPs and Tribune, the term social democracy was suspect because of its identification with a particular strand of socialist thought and politics. 
Another undercurrent in post-war British socialists' rejection of a social democratic identity was a self-righteous rejection of anything with demonstrably German antecedents. A British refusal to recognise common roots with things German was understandable for the generation who fought the Second World War. Its transmission to the successive three generations is remarkable. The underlying similarity between German social democracy and British labourism is undeniable. It springs from a common historical experience: on the economic front, early, intensive industrialisation and urbanisation; on the political front, the vagaries of constitutional monarchies where substantial residual power lay with a narrow elite; on the cultural front, the inheritance of the Reformation and the particular kind of conscientious individualism which it produced. Important exceptions can, of course, be found to these sweeping generalisations, e.g., in the pre-1914 empires, rural Catholic Bavarian peasants and rural Catholic Ireland. But the similarities are at least as instructive as the differences. Failure to recognise them and appreciate their significance has produced significant distortions in British politicians' and intellectuals' ability to understand the vagaries and vicissitudes of their own past.

In these respects, the Anglo-German similarity is in sharp contradistinction to France, where the first victory in the struggle for democracy was won in the decade after 1789. The emergence of le peuple and la nation, their collective political expression, as actors on the historical stage occurred before either industrialisation or extensive urbanisation. The potent force of democracy in France was unleashed not by or in the name of an urban proletariat, but rather by a wonderfully diverse collection of merchants, artisans, dissident aristocrats, shopkeepers, clerics, lawyers, and newly enfranchised wealthy peasants. By the 1850s in France, the defence of $L a$ Republique was a matter of universal concern. Countervailing forces, i.e. monarchism and ultramontane Catholicism, were ambitious but ultimately unable to reclaim the central ground of French politics. When Jules Guesde founded the French Workers' Party (POF) in 1879, he took counsel from Marx in London, explaining that 'he needed to "cut the cable that kept our workers in radical or bourgeois Jacobin waters"' (Gildea 2002: 315).

In Britain and Germany, the political elite maintained its ascendancy throughout the nineteenth century. Constitutional monarchies maintained a firm grip on the state and the political process in both spaces (in Germany this meant until 1871 the thirty-odd states remaining after Napoleonic consolidation). Intermittent manifestations of the 'the people's will' were contained with comparative ease, partly by efficient state repression but also because of the willingness of the elite to give ground under pressure, often slowly, but nonetheless tangibly. 


\section{The democracy ...}

The term 'democracy' was not inserted to proclaim the difference between social democratic parties and a non-existent communist party. In 1875 , 'Social' and 'Democratic' had equal importance for the Allgemeiner deutscher Arbeiterverein (General German Workers' Union) and the liberaldemocratic Verband deutscher Arbeitervereine (League of Workers' Clubs), the two founding groups of the Sozialdemokratische Partei Deutschlands (Social Democratic Party of Germany). 'Their anti-Prussianism was stronger than their socialism, to which, indeed their organizations did not commit themselves until 1868-9.' The Verband was based in 'Saxony, south-west Germany, and parts of Bavaria, where the Great German tradition of 1848 was still alive' (Craig 1981: 94). The SPD was a social-democratic party because it claimed not only political, but also economic rights. It is also possible that the SPD's founders, August Bebel and Wilhelm Liebknecht, like their British counterparts Keir Hardie and Will Thorn, considered it inexpedient to identify their political party too closely with an ismus. Sozialdemokratie may have been not only a more accurate descriptor than Sozialismus, but also more acceptable to contemporary political discourse.

It is equally important to remember that the goals of the men and women who founded the British Labour Party were not merely social, e.g. old age pensions, social insurance, but also democratic, e.g. proportional representation, the payment of MPs and universal suffrage. For both German and British parties, universal suffrage meant not only the enfranchisement of propertyless males, but also female suffrage. The charismatic Keir Hardie was an uncompromising champion of votes for women. Bebel's book, Die Frau und der Sozialismus, published in 1883, was reprinted fifty times before the First World War (Thorpe 2008: 30-1; Craig 1981: 210-11).

British trade union leaders, like Richard Bell and Tom Mann, welcomed the twentieth century with boundless self-confidence and were determined to wrest political control away from the narrow elite who predominated in both houses of Parliament. Bevin was clear that 'the democracy' needed political power:

The Trade Union Movement has wrenched the power from the castle and the mansion and handed it to the cottage. Gradually, as the ages rolled on, the serf class have risen in their majesty ... and they are walking more erect as citizens in this age than any previous age ... I am more proud of the movement, because out of their two-pences [to unions' political funds], you have created a royal road from cottage to Parliament so that sons of toil can express and use the very franchise which their forefathers won them, in helping to work out the salvation of the common people. (Bevin 1925) 


\section{$\ldots$ and the social}

After the First World War, when the Labour Party appeared to be a serious threat in Westminster, the Conservatives routinely referred to them as Socialists. So did the Daily Mail. Having temporarily abandoned the epithet during the wartime coalition, Churchill returned to the habit in opposition. After the Conservative defeat in July 1945, the Tory Party chairman, Lord Woolton, laid down a dictum that the Labour Party were never to be called by that name, but always referred to as the Socialists. Whether and in what way this name-calling had any impact is unclear.

The attempt to smear Labour with an ideological brush probably had little serious effect, other than confirming retired colonels' and blue rinse ladies' prejudices. It is unlikely to have influenced the outcome of elections in many marginal constituencies. There may also have been a positive effect. Being called socialist by one's opponents compelled one's thoughtful supporters to examine whether or not they were socialists, and of what socialism actually consisted. And certainly for the generation who were growing up during the 1945-51 Labour government, 'socialism' had a clear practical meaning. It was what happened during those seven years. Bevin had become Foreign Minister in that government. He is memorably shown on newsreels signing a treaty with his French counterparts in 1948, and declaring 'I am signing this treaty of friendship on behalf of Socialist Britain ...'

I can remember talking to a woman who taught secretarial studies in the higher education college where I taught shop stewards in North West London. She had grown up in Ealing in the 1940s, and was interested generally in the world, although not passionately political. It was Mrs Thatcher's second term and we were making conversation at the photocopying machine. She described herself quite unselfconsciously, 'My father was a socialist and I've always been a socialist'.

After three Rethinking Social Democracy conferences, my conclusion is that the term 'social democracy' is a reasonable linguistic approximation to the trade union and labour movement of which I feel a part. I am also prepared to accept its historical resonances. In 2008 its use as a pejorative insult by communists on the one hand and a badge of honour by centre-right cold warriors no longer seems relevant. It is difficult, for example, to distinguish the policies of the communist government of the Indian state of Kerala from the orthodox social democratic canon. Similarly, the extensive use of targets and detailed central planning in both education and the NHS by the Labour government has clear parallels with developments in the USSR and also with large capitalist corporations. 


\section{The German in social democracy}

The German SPD was the dominant party in the Second Socialist International, not only because of its size and the number of MPs in the Reichstag, but also because of the immense prestige it had gained by successfully defying Bismarck. Instead of expiring as a result of the repressive antisocialist laws passed in 1878, the SPD increased its parliamentary representation and cemented the loyalty of the newly emerging industrial proletariat. In March 1890, the new Kaiser, Wilhelm II, dismissed Bismarck and the antisocialist laws were allowed to lapse.

Not surprisingly, men and women who decided on the names of socialist parties founded after the SPD frequently decided to call themselves a Social Democratic Party in emulation of the SPD's triumph over the Iron Chancellor, for example the Belgian and Swedish socialist parties. Like the Germans, their founders were also keen to claim 'democracy' in order to stake their claim to the removal of property qualifications for parliamentary elections. Universal manhood suffrage was won in Belgium in 1913 as a result of an effective general strike, which convinced Luxemburg among others of this weapon's effectiveness in the proletariat's political armoury (Polasky 1995).

On 9 November 1918, the German SPD accepted the challenge of forming a new state, after the German General Staff had decided the war was lost and applied irresistible pressure on the Kaiser to abdicate; the SPD leader, Philipp Scheidemann, proclaimed the German Republic at a mass demonstration in front of the Reichstag. After this political revolution, Germany ceased to be a constitutional monarchy and the SPD predominated in the provisional government. Leading members of the USPD, notably Kautsky and Bernstein, came back to the SPD and played a part in the formulation of the Republic's constitution.

Contemporaries inevitably compared the German revolution with its Russian counterpart of one year previously. Their conclusion usually depended on two factors: (a) their politics; and (b) which side they had supported in the First World War. The new German republic suffered a bad press in most of the Allied countries, while the assassinations of Karl Liebknecht and Rosa Luxemburg were routinely cited as evidence of the SPD's callous attitude towards members of the working-class movement. There is no significant evidence to show that either the SPD or the constitutional structure of the Weimar Republic led directly to Hitler's coup d'etat in 1933. Social democrats' achievement in establishing a democratic republic has been rubbished by post-1933 hindsightism. While such a negative verdict was understandable during the Nazi Zeit, during the war, and in the immediate post-war period, it is no longer acceptable. A re-examination 
of the Weimar Republic is currently proceeding slowly, mainly on the cultural front (Weitz 2007). But its political legacy still awaits serious consideration by a new generation of scholars. ${ }^{4}$ The principal democratic contours of the Weimar constitution were re-enacted in the 1949 constitution of the Bundesrepublik, including the provisions for industrial democracy (Betriebsräte).

\section{Enter revisionism}

When Francis Fukuyama proclaimed the end of history in the 1990s, he was suffering from the onset of hubris, a dysfunctional condition to which triumphal victors frequently fall victim. Fukuyama sincerely believed that he had supported the winning side. With the fall of the wall the ultimate battle had been won and humankind would never again have to face another total, global conflict (Fukuyama 1992). Fukuyama evidently mistook the heady euphoria of men and women joining hands across the rubble of the Berlin Wall for an eternal condition.

Karl Marx was in much the same condition in 1848 when he wrote The Communist Manifesto. Intoxicated by the heady winds of change which blew through Europe during the springtime of nations, he confidently predicted the end of capitalism and the triumph of the workers of the world. Marx caught a serious dose of hubris, which lasted into his completion of the first volume of Kapital. By the time he began work on Volume III, he had recognised that there were too many significant countervailing forces for capitalism to be caught in the maw of its own contradictions. Nor was the industrial proletariat being progressively immiserated.

The posthumous publication of Volume III produced palpable unease and confusion in the Second International. There was no evidence that Marx still expected capitalism's imminent demise. This notable absence of revolutionary optimism called forth three responses in the socialist and trade union movement, which had been expanding throughout Europe since the 1870s. First, the fundamentalists or purists, whose lodestar continued to be a belief in the transformative qualities of revolution. They simply ignored the content of Volume III and remained focused on Volume I. Their justification for a continuing faith in the inevitability of revolution was the French Revolution from 1789-99, a living past, not even a century old when the purists, Rosa Luxemburg, Parvus and Belfort Bax, attacked the first revisionist, Eduard Bernstein.

The second response was revisionism, which attempted to deal with the changes which had taken place, both in capitalism and Marx's analysis of it. Bernstein argued that socialists' expectations of what was possible for the movement to achieve had to take account of the difference between politics 
and economics. If the bourgeois state suddenly failed or fell victim to an internal crisis (as had Louis XVI's absolute monarchy), creating the opportunity for a workers' state to arise, a socialist economy would not automatically rise out of the ashes. The economic system of capitalism would remain intact, and would have to be maintained. The process of replacing capitalism with socialism was not only a matter of politics. It would also be the result of a gradual evolution of more cooperative methods of production (Bernstein 1993).

The ideological battle between Bernstein's supporters and his revolutionary opponents was conducted with great passion at the beginning of the twentieth century, not only in Germany but also in successive Congresses of the Second International. Bernstein's principal supporters were social democrats and trade union leaders who were benefiting from the increased representation of socialists and social democrats in national parliaments (not only the Reichstag but also the Belgian and French Parliaments), and from south-west Germany, notably Baden, Hesse and Württemberg, where universal manhood suffrage and strong liberal traditions produced a more reformist political culture in state parliaments and governments. It was evident that political power could be used to modify and regulate capitalism. Although legislation could not abolish an economic system, laws which for example established a minimum wage, limited the working day, or prohibited child labour, produced significant improvements for the industrial proletariat.

A fault line inside the social democratic movement was clearly discernible by the second decade of the twentieth century, between those purists who drew inspiration from the Jacobin, revolutionary tradition of the young Marx and the pragmatists who turned to Bernstein for ideological justification. It is a division which has continued into 2008 and will surely carry on for as long as there is a socialist movement (post-war British revisionists are considered in Chapters 10 and 11 in this book). Before 1914, the division was papered over by dint of the application of large amounts of ideological glue. The glue dispensers, or emollients, constitute the third response. Their purpose is to keep the movement together, thereby rendering it capable of attracting support and winning elections. For example, August Bebel persuaded Karl Kautsky to do an intellectual hatchet job on Bernstein, even though Kautsky had told Victor Adler in personal correspondence that Bernstein was right (Tudor and Tudor 1988).

But, as Andrew Thorpe has shown in the British context, doing away with the emollients, and exposing the division between purists and revisionists has a tangible utility. Thorpe's work on the interwar British communist party highlighted the fact that its leadership made no attempt to supersede or replace the Labour Party as an alternative governing party. Instead, 
Harry Pollitt and Johnny Campbell engaged with the practical reality of British parliamentary politics and maximised the CPGB's leverage on the centrist Parliamentary Labour Party. Their influence depended not only on the USSR's growing prestige in the 1930s (in contrast to global capitalism's dismal state). They also staked a claim to be the most democratic part of the trade union movement, with their activist members operating as shop stewards and providing leadership for the 'rank-and-file' (Thorpe 1998: 2000). The CPGB was able to maximise its influence precisely because it was outside the institutional structure of British Labour, and thus immune from applications of ideological glue.

The current situation in Germany provides striking proof of Thorpe's thesis. The electoral success of the Linkspartei and the skill of its leadership have pushed not only the SPD, but also Merkel's Christian Democrats leftwards. The voting system of proportional representation and the consequent necessity for politicians to participate in coalition governments enables German trade unionists and citizens to wield more influence over their political process than in Britain, with its winner-takes-all system or Italy, where political parties at the national level were never compelled to accept a responsibility to civil society. Arguably, it is the personal ambitions of political leaders and their desire to enjoy the material spoils of government which motivates Peer Steinbrück and even Andrea Nahels to view Die Linke as the main enemy (Chapter 7 in this book provides a concise analysis of these developments). It will be fascinating to see whether in the next twenty years or so the SPD is able to adjust to having a significant party on its left. If it is unable to do so, then the Christian Democrats, as presently constituted, will swiftly step in to occupy the centre ground.

\section{Social democracy baulked?}

The majority of the conference papers focused on the post-1968 period. The analyses by Tsarouhas, Clift and Kennedy of social democratic governments' performance in Sweden, France and Spain show significant achievements and advances in expanding social provision and civil rights. Nevertheless, these practical results have been disappointing for many socialists and trade unionists. There is a palpable lack of pride in the record of social democracy. I can think of two interlinked explanations for the onset of demoralisation. First, the failure of social democratic theory to make further meaningful revisions. Although, as Pautz, Shaw and Lavelle point out, there have been many contemporary dilutions of socialism, there has been a remarkable lack of genuine revisionism. The study of Crosland in this book (Chapter 11) is highly relevant in this respect. Crosland had studied Bernstein before he began on his own revisionist exercise. He 
offered a comprehensive survey of how socialist principles might be applied to the world of the 1950s. There has been nothing comparable since.

Second, the failure of West European social democratic parties to recover from the demise of communism. It is interesting evidence of the effect of the two movements' shared parentage. During the cold war, the existence of large numbers of communist states acted as a strong bargaining card for social democratic parties and trade unions. Social democrats became accustomed to gaining concessions from employers, augmenting the welfare state and piloting through extensions of industrial democracy. They were able to argue successfully for a more equal distribution of wealth and income by citing the spectre of communism, and warning that unless concessions were made the result might be not only unrest but also revolution! The glorious events of 1968 (and Italy's hot autumn of 1969), made this Armageddon scenario all too credible to the political and economic elites.

\section{Future-gazing}

Bernstein's goal of achieving cooperative organisation in the economy and also civil society is still a valid one. However, if contemporary social democrats are going to move forward, they will have to first enquire what has changed in capitalism, and how those changes affect society. From the 1990s, it became highly fashionable to point to the prosperous present and a glowing future which beckoned for global capitalism. The economic stimulus produced by the end of the cold war in continental Europe and the seemingly limitless expansion of finance capital were apparently reinforcing each other. Meanwhile, in the USA, enterprising, ambitious people were clawing their way to the top, using the privatisations of utilities and the amazing loopholes (euphemistically described as opportunities) provided by the harnessing of computer models, e-mail, and mathematics to amass paper money fortunes which had little or no counterpart in reality.

In 2008, the many economists and journalists who had signed up to the triumphalist version of the end of the cold war have been shocked by the fact that the future of capitalism looks increasingly insecure. They had apparently concluded that, since the implosion of the USSR had proved capitalism to be a superior economic system, its indefinite expansion with resulting enrichment for deserving entrepreneurs and investors would become the New World Order. A mirror image of pro-capitalists' shock can be seen in the glee and 'I told you so' responses coming from pure socialists, who view the current vicissitudes of the global economy as being a sign that the downfall of capitalism is nigh.

The practical reality of the current economic situation is much more complex. A recently issued report from theBank of International Settlements 
concluded that the underlying causes of the credit crunch and continuing financial insecurity were the opportunities for old-fashioned greed opened up by the retreat of state financial regulation (Wolf 2008). Provided that governments and national banks find the will to reassert control over financial institutions, there is no reason to doubt the Marx of Kapital Volume III: there will be countervailing forces powering capitalism forwards and upwards into the twenty-second century. But the continuing strength of capitalism does not mean that social democracy will inevitably become weaker. Indeed, social democracy was arguably strongest at the last zenith of global capitalism, at the beginning of the twentieth century. A strong capitalism creates the conditions for a strong trade union movement and also the militant expression of democratic demands (Chapter 14 on industrial democracy in this book is very relevant to this point).

Social democracy is guaranteed a secure future as a repository of ideas, whether or not it continues to be a living political movement. Outside Europe and North America, I am optimistic about its future as a political force. Interest in social democracy is strong in the newly industrialised economies of South Korea and Taiwan. In Brazil and Argentina, social democratic ideas are influential inside the trade union movement and political parties. Increasing urbanisation and industrialisation have produced qualitative changes in the political leaderships' self-image and selfconfidence. In India, the principles and perspectives of the British labour movement, from the Marxist Social Democratic Federation through to the CPGB, permeated the Congress Party from its inception. Increasing urbanisation and industrialisation have produced qualitative changes in India, which are making the political reflexes from this pre-1948 source increasingly relevant.

The problems for social democracy in Europe are different. In Western Europe, the horizons of social democratic politicians have been so narrowed that they are only interested in two things, winning elections and managing state services. Not surprisingly, electorates have ceased to have much interest in or sense of identification with the party leaderships. An interesting exception is arguably the Spanish socialist party, the PSOE. The Spanish socialist government has recently enacted an ambitious programme of civil, democratic rights, which are discussed by Paul Kennedy in Chapter 5 in this book. Their electoral success and determination to make further progress on the democratic front is evidence that the democratic part of social democracy deserves to be taken seriously, a point also made by Martin McIvor in Chapter 13 in this book.

The problem for social democratic parties in East Central Europe is different. For the most part their leaders have been unable to show voters that social democracy is very different, either programmatically or ideologically, 
from the parties which predominated in the pre-1989 states. Many of the dominant parties in East Central Europe were not called communist parties, for example the Polish United Workers' Party - PZPR - and the East German Socialist Unity Party - SED. As I have tried to show, the assertion of an absolute difference between social democratic and communist parties is in any case inaccurate. Many of the measures enacted by communist governments were popular and genuinely improved people's standards of living. Nonetheless, determination, commitment and time will be required before social democrats in these countries can convince their citizens that there are genuine differences between the communists and social democrats.

Finally, social democrats in both Western and East Central Europe will have to engage with a twenty-first century democratic problem-how to restructure the European Union so that the Commission and the Council are directly responsible to the citizens of Europe. In chapter 9 in this book, Moschonas has rightly, in my view, flagged this task up as being vital to the future of social democracy on this continent. This process will not involve the disappearance either of nations or nation-states. The construction of a more transparent and politically accountable EU Commission and Council will not affect the validity of these historico-cultural constructs. What will change, and rightly so, is the international dimension. There will be a new historical actor, joining le Peuple and la Nation. Without an effective EU on the international stage, there can be no reasonable expectation that European citizens will be able to continue to enjoy the civil and economic advantages which social democratic governments have brought them.

There is evidence that global capitalists and political leaders of the international community have been persuaded to take the problem of climate change seriously. Governments and international organisations will be compelled to deal with the effects of climate change using many non-market means. There are many precedents in nineteenth- and twentieth century European history for constitutional monarchies and bourgeois governments adopting non-market solutions, for example Napoleon III's economic policies which drew inspiration from Saint Simon or Stanley Baldwin's determination to proceed with the electrification of Great Britain using state finances and a state holding company. It will be surprising if in the twenty-first century such expedients are not adopted again. Provided they remain self-confident and vital, social democratic parties will be able to influence the direction and structure of these new non-market solutions.

\section{Notes}

1 I am grateful to John Callaghan and Ben Jackson for reading and commenting on the first draft of this chapter. 
2 The German word Wende means turn. It was quickly adopted by Germans as their shorthand for the events leading up to the destruction of the Berlin Wall in November 1989 and its immediate aftermath. Most other Western Europeans use 'the Fall of the Wall' to describe these events. I have used Wende because it conveys a sense of motion and change, while stopping short of describing the change as revolution.

3 Marx used the expression 'dictatorship of the proletariat' in Class Struggles in France, which dealt with the events of 1848-49. Engels repeated it in his introduction to Marx's The Civil War in France, an analysis of the Paris Commune. Neither, however, probed its substance. Parties affiliated to the Second International viewed the possibility that they might participate in a dictatorship of the proletariat with equanimity. Bernstein, for example: 'So, as the first precondition of the general realisation of socialism we have a certain level of capitalist development and, as the second, we have the exercise of political power by the class party of the workers, Social Democracy. In the transitional period, the form in which this power is exercised is, according to Marx, the dictatorship of the proletariat' (Bernstein 1993: 99).

4 A relevant example of the failure to analyse the German Revolution is a conventional view which condemns the provisional government's use of the Freikorps in 1919-20 to suppress the intermittent upsurges of resistance from workers' councils and/or urban unrest. The conclusion is that because the government allowed the Freikorps to deploy, they could no longer be considered social democratic, republican or revolutionary. However, if the suppression of workers' councils is to be used as a litmus test, then Lenin, Trotsky and the other Bolsheviks who participated in the brutal suppression of the Kronstadt Rebellion in February-March 1921 should also stand condemned. Although most historians today recognise the Bolsheviks' suppression of Kronstadt, they continue to regard the post-Kronstadt Bolshevik leadership as being sincere communists who were trying to construct socialism.

\section{References}

Bernstein, E. (1993) The Preconditions of Socialism, 1899, ed. and trans. H. Tudor (Cambridge: Cambridge University Press).

Bevin, E., speech in Yarmouth Town Hall on 23 March 1925, quoted in The Record, journal of the Transport and General Workers' Union, May 1925.

Craig, G. A. (1981) Germany 1866-1945 (Oxford: Oxford University Press).

Fukuyama, F. (1992) The End of History and the Last Man (New York: The Free Press).

Gildea, R. (2002) Barricades and Borders, Europe 1800-1914, 3rd edn (Oxford: Oxford University Press).

Morgan, K. (2006) The Webbs and Soviet Communism, Bolshevism and the British Left Part 2 (London: Lawrence \& Wishart).

Polasky, J. (1995) The Democratic Socialism of Emile Vandervelde Between Reform and Revolution (Oxford: Berg), Chapter 2. 
Thorpe, A. (1998) 'Comintern "control” of the Communist Party of Great Britain, 1920-1943’, English Historical Review, 113.

Thorpe, A. (2008) A History of the British Labour Party, 3rd edn (Basingstoke: Palgrave).

Tudor, H. and Tudor, J. M. (eds) (1988) Marxism and Social Democracy: the Revisionist Debate 1896-98 (Cambridge: Cambridge University Press).

Weitz, E. D. (2007) Weimar Germany: Promise and Tragedy (Princeton: Princeton University Press).

Wolf, M. (2008) 'The lessons to be learnt from today's financial crisis', Financial Times, 2 July, discussing Annual Report of Bank for International Settlements. 


\section{Index}

Note: ' $n$. ' after a page reference indicates the number of a note on that page

Adenauer, Konrad 30-1, 275

AFL-CIO 282n.6, 288

'Agenda 2010' 17, 23n.4, 32, 137-43, 179

see also Hartz reforms

Alternative Economic Strategy (AES)

$55-6,63,67,68 \mathrm{n} .2$

anti-globalisation or alternative globalisation movements 176 , 280

arts and cultural policy 20,133, 140, $184,195-213,262$

Austria 268, 270-4 passim, 281

Aznar, José María 98-102

Barber, Michael 147, 153-4, 211

Bauer, Otto 272

Berlusconi, Silvio 270

Bernstein, Eduard 218, 287, 292-6 passim, 299n.3

Bildt, Carl 116

Bismarck, Otto von 30, 292

Blair, Tony 4, 100-1, 135, 147-67, 179, 206-9, 211-13, 216, 224, 241

Brandt, Wily 276, 288

Brown, Gordon 4, 12, 152, 163, 197, 206-7, 212-13, 216, 229, 286
Canada 29

Carlsson, Ingvar 19

China 12, 46, 47, 207

choice, personal 59-60, 67, 148, 152, 154-64

see also freedom; liberty class

aristocracy 220, 237, 249n.13

conflict 10, 14, 19-20, 22, 53, 133, 212-13, 217, 220, 239-41, 252, $269,280,282$

middle 4, 11, 100, 131, 158-9, 202, 218, 228, 241, 249n.13, 257,278

working 13, 23, 30, 54, 57, 133,

135, 183-9 passim, 202-9 passim, 234, 241, 248, 258, 271-4 passim, 281, 290

Clinton, Bill 241

cold war 274, 286, 288, 291, 296

Cole, G. D. H. 57, 271-2

Communist Parties 268, 287-99

France 276

Germany 142, 275, 288, 298

India 291

Poland 298

Russia 287

Spain 94

UK 294-5 
council movement 268, 271

credit crunch 12, 297

Crosland, Anthony 5, 53-68 passim, 202-5, 210, 216-30, 288, 295

Czechoslovakia 268, 273

Delors, Jacques 64-6, 181, 188n.13 de Man, Hendrik 273-4, 281

education policy 130

Australia 20, 22

Germany 16, 32, 130-40 passim

Spain 96, 97, 101, 106

Sweden 18

UK 4, 34, 45, 53, 147-64, 195-213, 220-1, 224, 291

employment policy see labour market policy

equality 216 , see also inequality access (to services) 158-9, 163, 220-1, 228, 230

gender 105, 109, 118-20, 206, 256, 290

importance to social democracy 4 , 16, 73-4, 130, 216-26 passim, 241, 245, 252-3, 257, 261, 274 opportunity vs outcome 130-41 passim, 196-210 passim, 219-30 passim, 241

Esping-Andersen, Gosta 30

European Community see European Union

'European social model' 3, 19, 29-30, 45, 50-1, 75 see also European Union, 'social Europe'

European Union 4, 9, 45, 55, 62, 66, $77,96,105,108,124-5$, 168-92, 298

'Euro-Keynesianism' 64-5, 78, 81-2,178, 183

European Central Bank 41, 66, 80, 173,181

European Monetary System 78

Growth and Stability Pact 40, 80, 86-8
Maastricht Treaty 40, 181, 186

Single Currency 81-2, 86

Single Market 62, 64, 77, 186

'Social Europe', 64-6, 81-2, 169, $177,178-9,183-5$

Fabianism 59, 66-7, 198-9, 201, 205, 219, 272

see also Webb, Beatrice and Sidney freedom 9-10, 59-60, 67, 109, 129, 133, 141, 201-2, 209, 223, 225-6, 238, 242, 244-5, 249n. 14, 253-7 passim, 287 see also choice; liberty

full employment 1, 20, 53-4, 63-5, 73-89 passim, 112-18 passim, 134, 218-19, 242

Gauche plurielle 168, 188n.8

German Trade Union Confederation (DGB) 274-6

Giddens, Anthony 73, 75, 100, 129-31, 208, 211

globalisation 1, 9, 10, 23, 46-51, 63-5, 74-6, 85, 89, 113, 125, 133-41 passim, 176, 183-5, 188n.4, 224, 229, 270, 279, 280

see also markets, financial

González, Felipe 93-5, 97-9, 101-2, 104-5, 107-8

government spending see public spending

guild socialism 219, 268, 271-2, 280-1

'Hartz reforms' 32-3, 137-41

Hattersley, Roy 210, 22 5, 226, 230n.4

Hawke, Bob 20

Hayek, Friedrich 57, 58, 221, 223 , 225-6

Hilferding, Rudolf 272, 282n.3

housing

France 32, 35

Germany 35 
Spain 97

Sweden 18, 20

UK 33, 35, 195, 197, 200, 206

Hungary 268

immigration policy 106

Independent Labour Party, UK (ILP) 219

India 12, 207, 291, 297

Industrial Workers of the World (IWW) 272

inequality 1, 10, 14, 16, 130, 136, 140, 141, 158-9, 220-8 passim, 233-50, 257

International Monetary Fund (IMF) $11,43,54,186$

Ireland 40, 104, 289

Italy 2, 11, 270, 271, 272, 274, 295, 296

Japan 11-12, 29, 46, 47, 48, 64

Joseph, Keith 60, 205

Jospin, Lionel 3-4, 33, 73-88 passim

Juppé, Alain 32, 86

Keating, Paul 20

Keynesianism 1, 14, 73, 75-6, 89n.2, 130, 182-7 passim, 270, 273, 281

Australia 21-2

France 76-9, 84, 96, 107

Germany 132, 135

Spain 96

UK 3, 53-67, 218, 223

Kohl, Helmut 16, 29, 31, 41. 134

Korpi, Walter 267

labour market policy see welfare reform

Labor Party, Australia (ALP) 14, 20-2, 23, 24n.6-7

Labour Party, UK 4, 10, 14, 34, 45 , 53-68, 76, 129, 131, 134, 147-64, 168, 179, 196-7, 200-13 passim, 216-30, 233-8, 249n.7, 249n.15, 252, 274, 288, 290, 291, 294-5, 297

Lafontaine, Oskar 10, 133-7, 178

Lamy, Pascal 82

Laski, Harold 198

liberty 53, 100, 130, 219, 223, 225-6, 244-5, 254-6, 264n.3 see also choice; freedom

Lloyd George, David 233-48

markets

capital / financial 4, 53, 55, 59, 60, 63, 74-6, 77, 80, 87, 88, 89n.1, 98, 245, 262, 276, 279, 297 labour $16-17,30-51$ passim, 58, 65, 85, 89n.1, 113, 116-26, 129, 130-4, 136-42, 149, 224, 233, 257-60, 280 public services $4,19,60,67$, 68n.3-4, 147-64, 225-8 passim, 230 regulation of $14,19,40,135,173$, 179-80, 183, 185-6 role of $9,10,19,57-8,61,67,79$, 82-3, 89n.1, 130-2, 178, 210-11, 221, 222-4, 228, 237, 246, 257-9, 261-2, 275, 281, 298

'social market' 137-8, 140, 275 see also privatisation

Marquand, David 131, 149-50, 151, 161, 196, 205, 230n.3, 252

Marx, Karl 217, 230n.2, 259-60, 269, 289, 293-4, 297, 299n.3

Marxism 20, 23n.2, 94-5, 107, 131, 201, 218, 219, 223, 256, 259, 272-4, 282n.3, 293-4, 297

Meidner, Rudolf 277-9

Rehn-Meidner model 277 wage-earner funds 113, 114, 268, 277-80, 281

Mitterand, François 78-80, 88, 188n.13

multinational corporations 55, 279

Müntefering, Franz 138, 139 
Naphtali, Fritz 269-70, 274, 279 nationalisation see public ownership neo-liberalism 1-3, 5, 9-10, 14, 16, 23, 29, 75-7, 83, 88, 89n.1, 98-9, 103, 112, 130-4 passim, 168-9, 182, 186, 189n.17, $224,228,253,267-8,278$, 281-2

see also New Right

Netherlands 175, 273, 282n.2

Neue Mitte 133-4, 143

New Right 3, 57-60, 65, 67, 75, 98 , $164,205,216,217,223-4$ see also neo-liberalism

New Zealand 29, 186

pensions 39-40, 262, 279

Australia 20

France 32-3, 39, 44

Germany 15, 23n.4, 30, 31, 39, 41, 43

Spain 96-7, 104, 106-7, 116

Sweden 19, 120, 277-80

Switzerland 267

UK 30, 33-4, 39, 44, 227, 249n.7

Persson, Göran 19, 116, 126

Pettit, Philip 100-1, 105, 253, 254-6, $264 n .3$

planning 20, 55-7, 131, 219, 260, 263-81 passim, 282n.3, 288, 291

Polanyi, Karl 82-3, 89n.2

Portugal 40

privatisation 1, 10, 31

Germany 43

Sweden 115,

UK 33, 60-1, 67, 148, 152, 156-7, $164,207,224-5,229$

USA 296

public expenditure see public spending public ownership 196, 208, 221-2, 260, 263

Australia 20

France 276

Germany 275
UK 33, 53-7 passim, 61, 203, 208,

218, 221-4 passim, 229

see also socialisation

public spending $1,10,29,58-9$

Australia 20-1

European Union 65-6, 179

France 84, 87, 88

Spain 85, 97

Sweden 18, 115, 116

UK $33-4,45,54,61,65,160,222$, 224

Raffarin, Jean-Pierre 33, 87

Rathenau, Walther 271

Rawls, John 136, 142, 261

Reagan, Ronald 10

republicanism 5, 100-1, 239, 252-64

revisionism 1-2, 4, 61-2, 112, 129,

$167,184,200-5$ passim, 217-30

passim, 273-4, 293-6

Roosevelt, Franklin 235, 238-48

Sarkozy, Nicholas 29-30, 33, 44

Sassoon, Donald 1, 2, 183, 275 ,

277-9, 282n.5

Schmidt, Helmut 16, 132, 276

Schröder, Gerhard $16-17,31,134-8,140,141-2$

Sen, Amartya 142

Shaw, George Bernard 220

Social Democratic Federation, UK (SDF) 258, 297

Social Democratic Party, Germany (SPD) 4, 10, 14, 15-17, 23, 129-43, 179, 275, 282n.3, 287-95 passim

Social Democratic Party, Sweden (SAP) $4,14,17-19,23 n .5,112-26$, 277-8, 292

Social Democratic Party, Switzerland 267

socialisation $260,262,268-74,281$

see also public ownership

Socialist Party, France (PS) 3-4, 73-89, 96, 188n.13 
Socialist Party, Switzerland 273

Socialist Workers Party, Spain (PSOE)

4, 93-109, 253, 297

Soviet Union 271, 276, 287-8

state, role of 9-10, 33-4, 39-40, 51, $57-9,64,75,130-1,135-6$, 183, 184, 198, 203, 205-7, 218, 223-4, 229, 238, 244-8 passim, 252, 270-2, 294, 298

Australia 21-2

'competitive state' $46-8$

France 76-7, 83-5

Germany 133-42, 289, 292

'market-state' 148

'social investment state' 130, 138

'social state' 140

Sweden 113, 115, 119, 121

UK 45, 61, 147-8, 152-60 passim, 289

see also markets; public ownership

Steck, Albert 270, 282

taxation 1, 10, 13, 36, 38-41, 48-51, $60,130,179,223,233,240$, 244,262

France $32-45$ passim, 84, 87

Germany 16, 17, 30-43 passim, 37, 140

Spain 97, 99, 104, 106, 108, 109

Sweden 19, 114, 116, 125

UK 33-51 passim, 152, 205, 207, 220, 222, 227, 233-42 passim

USA 234, 240

Thatcher, Margaret 10, 60-1, 66, 206, 223-4, 291

Third Way 3-4, 67, 101, 129-31, 242,280

Germany 134, 136, 139, 142

Sweden 115-16

UK 67, 179, 216, 224 trade unions $1,11,53,56,64,77$, 176, 217-18, 263, 267-82, 290-7 passim

in Argentina 297

in Brazil 297

in France 32, 77, 272, 276, 282n. 5

in Germany 16, 31, 132-4, 137, 142, 268-9, 271-6, 295

in Spain 96-7

in Sweden 112-26, 268, 277-8

in Switzerland 267, 273

in UK 55, 56, 63-4, 156, 207, 271 , 288, 290, 295

in USA 239, 244-5, 272, 282n.6

in USSR 287, 288

transnational corporations see multinational corporations

TUC, UK 63

unions, see trade unions

USA 11, 12, 46-8, 82, 220, 275, 272, 282n.6, 296

Von Mises, Ludwig 58

'Washington Consensus' 10, 14

Webb, Beatrice and Sidney 199, 269 , 288

welfare reform 1, 130-1

in France 32-3, 51

in Germany 16, 17, 23n.4, 30-3, 35, 51, 137-43, 179

in Spain, 96-7

in Sweden 115, 116, 122, 123

in UK 33-5, 227

see also markets, labour

Whitlam, Gough 20-2

working class see class

Zapatero, Rodríguez 93-4, 100-9 


